\title{
An investigation of hydrogen supplementation on combustion and emissions of heavy-duty diesel engines
}

ChetMun Liew

West Virginia University

Follow this and additional works at: https://researchrepository.wvu.edu/etd

\section{Recommended Citation}

Liew, ChetMun, "An investigation of hydrogen supplementation on combustion and emissions of heavyduty diesel engines" (2010). Graduate Theses, Dissertations, and Problem Reports. 4626.

https://researchrepository.wvu.edu/etd/4626

This Thesis is protected by copyright and/or related rights. It has been brought to you by the The Research Repository @ WVU with permission from the rights-holder(s). You are free to use this Thesis in any way that is permitted by the copyright and related rights legislation that applies to your use. For other uses you must obtain permission from the rights-holder(s) directly, unless additional rights are indicated by a Creative Commons license in the record and/ or on the work itself. This Thesis has been accepted for inclusion in WVU Graduate Theses, Dissertations, and Problem Reports collection by an authorized administrator of The Research Repository @ WVU. For more information, please contact researchrepository@mail.wvu.edu. 
An Investigation of Hydrogen Supplementation on Combustion and Emissions of Heavy-Duty Diesel Engines

\title{
ChetMun Liew
}

\author{
Thesis Submitted to the \\ College of Engineering and Mineral Resources \\ at West Virginia University \\ in partial fulfillment of the requirements \\ for the degree of
}

Master of Science
in
Mechanical Engineering

Hailin Li, Ph.D., Chair

Nigel Clark, Ph.D.

Benjamin Shade, Ph.D.

Department of Mechanical and Aerospace Engineering

\author{
Morgantown, West Virginia \\ 2010
}

Keywords: $\mathrm{H}_{2}$-Diesel Dual Fuel, Hydrogen, Emissions, Combustion 


\section{ABSTRACT}

\section{An Investigation of Hydrogen Supplementation on Combustion and Emissions of \\ Heavy-Duty Diesel Engines}

ChetMun Liew

Hydrogen $\left(\mathrm{H}_{2}\right)$ has long been recognized as a carbon-free fuel having excellent combustion characteristics compared to hydrocarbon fuel. This research investigated the effects of $\mathrm{H}_{2}$ addition on the performance, combustion, and emission characteristics of two turbocharged heavy-duty diesel engines. The effects of $\mathrm{H}_{2}$ addition, engine load, engine speed, and diesel fuel flow rate on the brake thermal efficiency (BTE), cylinder pressure, combustion process, and exhaust emissions of Oxides of Nitrogen $\left(\mathrm{NO}_{\mathrm{x}}\right)$, Particulate Matter (PM), Carbon Monoxide (CO), Unburned Hydrocarbon (HC), and Carbon Dioxide $\left(\mathrm{CO}_{2}\right)$ were explored. The engine load was varied from 10 to $100 \%$ with $\mathrm{H}_{2}$ concentration in the intake mixture $\left(\mathrm{H}_{2} /\left(\mathrm{H}_{2}+\mathrm{Air}\right)\right.$, vol.) varied from 0 to $7.5 \%$. Engine speed was varied from 1200 to 1800 RPM.

The addition of $\mathrm{H}_{2}$ to a 1999 Cummins ISM370ESP engine and a 2004 Mack MP7 355E engine was shown to reduce substantially the emissions of $\mathrm{PM}, \mathrm{CO}$, and $\mathrm{CO}_{2}$. In comparison, the effect of $\mathrm{H}_{2}$ addition on the emissions of $\mathrm{HC}$ was relatively small. When operated at 30 to $70 \%$, the addition of $\mathrm{H}_{2}$ (3-6.5\%) enhanced the $\mathrm{NO}_{\mathrm{x}}$ emissions of the 1999 Cummins ISM370ESP engine. The emissions of $\mathrm{NO}_{\mathrm{x}}$ at $70 \%$ load increased almost linearly from 3.34 to $4.66 \mathrm{~g} / \mathrm{bhp}$-hr with the addition of $6 \% \mathrm{H}_{2}$. However, the addition of $\mathrm{H}_{2}$ had mild effect on the $\mathrm{NO}_{\mathrm{x}}$ emissions of the 2004 Mack MP7 355E. The substantial reduction of $\mathrm{NO}_{\mathrm{x}}$ emissions was only observed with the addition of relatively large amounts of $\mathrm{H}_{2}$ (5-6.5\%) at a very narrow low load operational range (10-20\%). When operated at $10 \%$ load, the addition of $6 \% \mathrm{H}_{2}$ to a 1999 Cummins ISM370ESP engine reduced $\mathrm{NO}_{\mathrm{x}}$ emissions from 5.23 to $0.54 \mathrm{~g} / \mathrm{bhp}-\mathrm{hr}$.

The improvement to the BTE has been one of the main objectives of this engine research. The addition of a relatively large amount of $\mathrm{H}_{2}$ (3-7\%) at the range from 20 to $100 \%$ load improved the BTE for both engines. When operated at $70 \%$ load, the BTE improved from 41.7 to $43.6 \%$ with the addition $6 \% \mathrm{H}_{2}$ for 1999 Cummins ISM370ESP. In comparison, the addition of a relatively small amount of $\mathrm{H}_{2}(0-2 \%)$ lowered the BTE. When operated at $70 \%$ load, the BTE slightly reduced from 41.7 to $41.3 \%$ with the addition of $1 \% \mathrm{H}_{2}$ for 1999 Cummins ISM370ESP. The addition of $\mathrm{H}_{2}$ at $10 \%$ load was found to reduce the brake thermal efficiency for the range of data measured. The combustion analysis demonstrated the significant effect of $\mathrm{H}_{2}$ addition in enhancing the heat release process and increasing the peak cylinder pressure when operated at 30 to $70 \%$ load. However, the addition of $\mathrm{H}_{2}$ at 10 and $15 \%$ load was shown to slightly retard the combustion phasing and lower the peak cylinder pressure. 


\section{ACKNOWLEDGEMENTS}

I thank my advisor, Dr. Hailin Li for giving me the opportunity to attend graduate school and participate in this research program, and also for supporting me well enough until the end of my graduate school. I have greatly appreciated your guidance and thank you again for being my advisor.

I also credit my committee members, Dr. Nigel Clark and Dr. Benjamin Shade for their guidance and active participation as my committee members. Drs. Nigel Clark and Benjamin Shade have shared their previous research experience to help inspire and shape my research direction.

My beloved parents were also a big contributors although they are not residing in United States. They have showed great support and guidance on my research, and personal expenses. To my sisters, Evelyn and Sean, thank you for keeping me updated periodically on either family's news or local news. My aunts who live in New York City, have also showed great financially support to me. To my girlfriend, Juliana Yap, thank you for feeding me when I am hungry. Your great support and caring has contributed to a success with my project. You and your piano music meant a lot to me and I am looking forward to the days we spend together in the future.

Special thanks to the staff of WVU CAFEE and also the students, Thomas Spencer, Richard Atkinson, Zac Luzader, Dr. John Nuzskowski, Bradley Ralston, Byron Rapp, Susan Xu, Wayne Hilderbrand, Nathan Music, Chris Beers, Timothy Gatts, Shiyu Liu, Pingen Chen, Jacob Brown, Balaji Seward, Marc Besch, Mano Thiagarajan, and Arvind Thiruvengadam for their assistance in conducting this project. Their professionalism has made this project into a huge success. 


\section{TABLE OF CONTENTS}

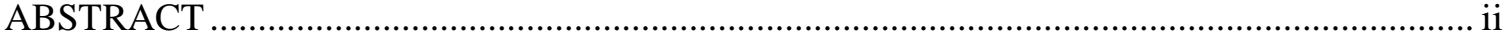

ACKNOWLEDGEMENTS ………………......................................................................... iii

TABLE OF CONTENTS …………………………………………………………….... iv

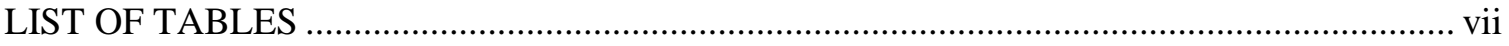

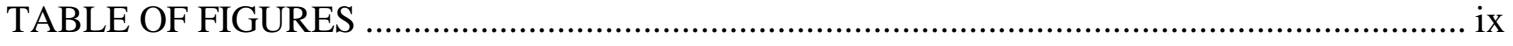

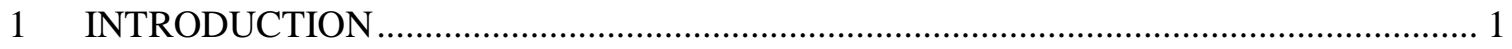

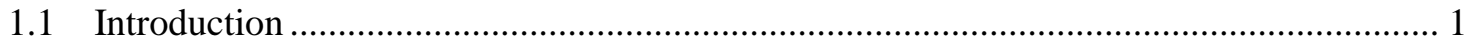

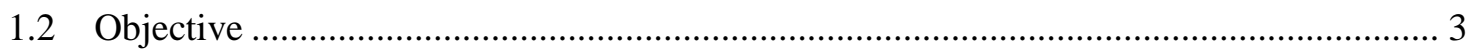

2 LITERATURE REVIEW ………………………………......................................... 4

2.1 Hydrogen Application as Fuel................................................................................. 4

2.1.1 Application of $\mathrm{H}_{2}$ in SI Engines ....................................................................... 4

2.1.2 Application of $\mathrm{H}_{2}$ in Compression Ignition Engines as Sole Fuel........................... 5

2.1.3 Application of $\mathrm{H}_{2}$ in Diesel Engines as Supplemental Fuels.................................. 6

2.2 Literature Review of $\mathrm{H}_{2}$-Diesel Dual Fuel Engine …………........................................... 7

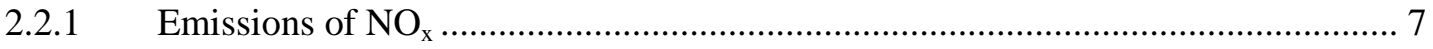

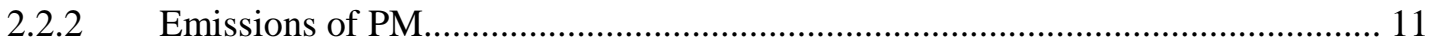

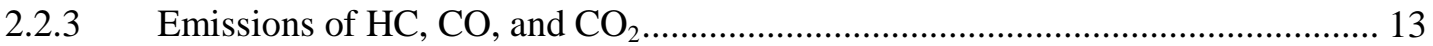

2.2.4 Brake Thermal Efficiency ………………………………………………………. 13

3 EXPERIMENTAL SETUP AND SAFETY APPROACH ……………………………….... 16

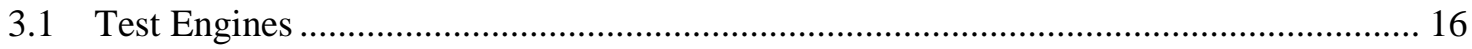

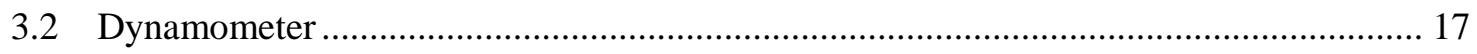

3.3 The Measurement of Exhaust Emissions …………………………………………... 18

3.3.1 Dilution Tunnel ............................................................................................ 18

3.3.2 Measurement of Gases Emissions .................................................................. 19

3.3.3 Measurement of PM Emissions .......................................................................... 20 


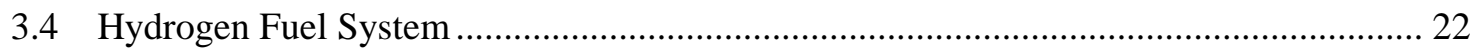

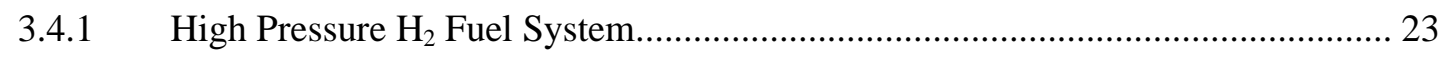

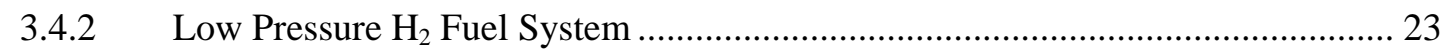

3.4.3 Safety System and Safety Operation Procedure ................................................ 24

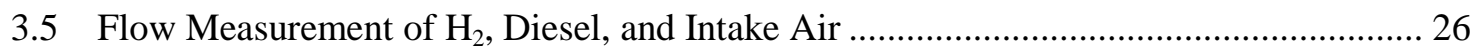

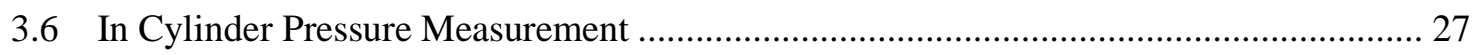

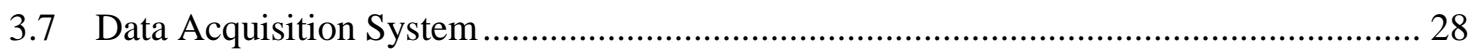

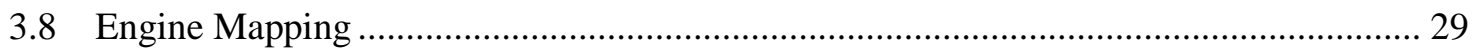

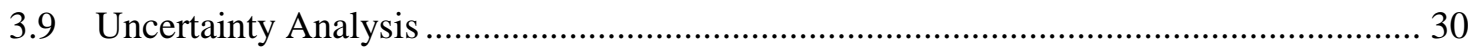

4 INVESTIGATION OF EMISSIONS AND COMBUSTION OF A 1999 CUMMINS

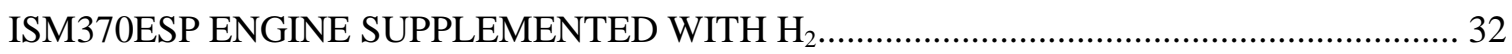

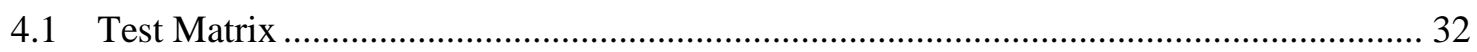

4.2 Repeatability of Exhaust Emissions and Fuel Consumption Measurement ..................... 37

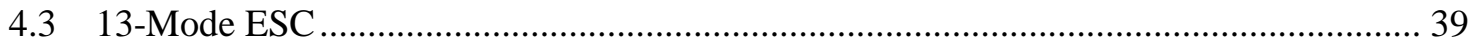

4.4 Effect of $\mathrm{H}_{2}$ Addition and Engine Load on Exhaust Emissions .................................... 43

4.4.1 Effect of $\mathrm{H}_{2}$ Addition on the Emissions of $\mathrm{NO}_{\mathrm{x}}, \mathrm{NO}$, and $\mathrm{NO}_{2} \ldots \ldots \ldots \ldots \ldots \ldots \ldots \ldots \ldots . . . . . . . . . . . . .43$

4.4.2 Effect of $\mathrm{H}_{2}$ Addition on the Emissions of PM .............................................. 47

4.4.3 Effect of $\mathrm{H}_{2}$ Addition on the Emissions of CO................................................ 49

4.4.4 Effect of $\mathrm{H}_{2}$ Addition on the Emissions of HC.................................................. 50

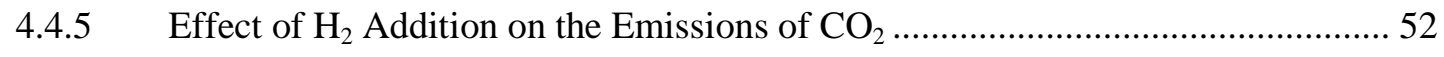

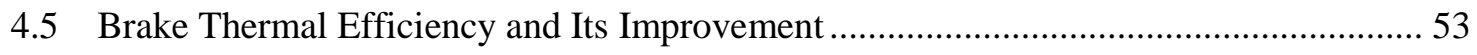

4.6 Effect of $\mathrm{H}_{2}$ Addition on Cylinder Pressure and Heat Release Process .......................... 57

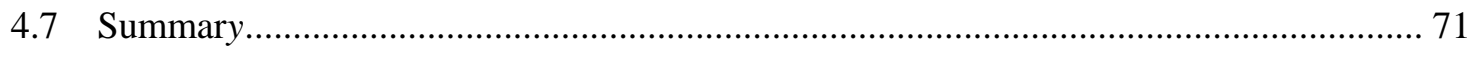

5 INVESTIGATION OF EMISSIONS AND COMBUSTION OF A 2004 MACK MP7 355E

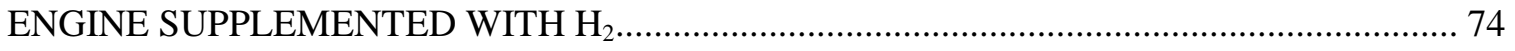

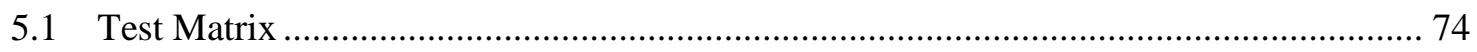

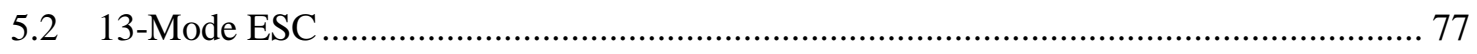




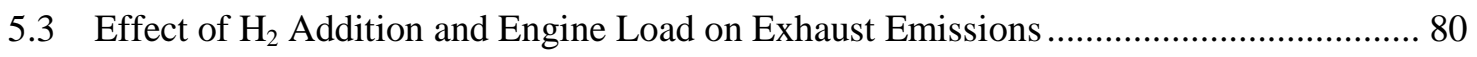

5.3.1 Effect of $\mathrm{H}_{2}$ Addition on the Emissions of $\mathrm{NO}_{\mathrm{x}}, \mathrm{NO}$, and $\mathrm{NO}_{2} \ldots \ldots \ldots \ldots \ldots \ldots \ldots \ldots \ldots . . . . . . . . . . . . . .60$

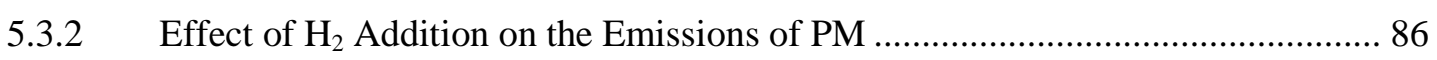

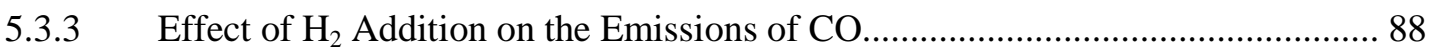

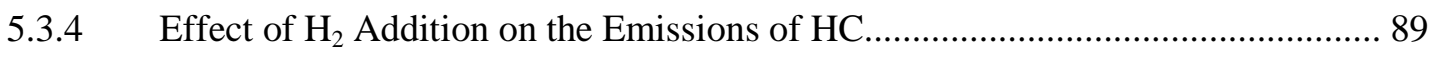

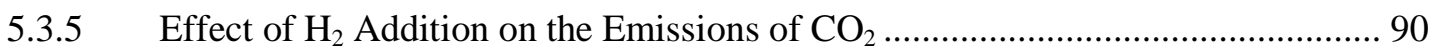

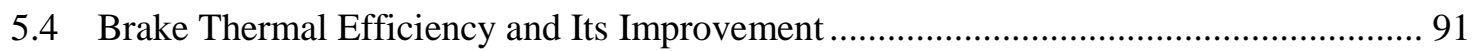

5.5 Effect of $\mathrm{H}_{2}$ Addition on Cylinder Pressure and Heat Release Process........................... 98

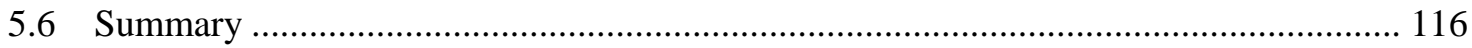

6 CONCLUSIONS AND RECOMMENDATIONS ........................................................ 119

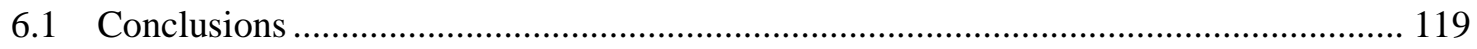

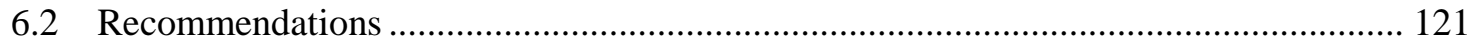

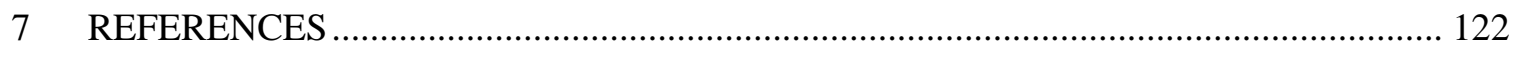

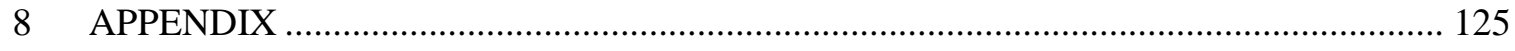




\section{LIST OF TABLES}

Table 1 Variation of Thermal Efficiency with the Addition of $\mathrm{H}_{2}$ [McWilliam et al., 2008] ....... 15

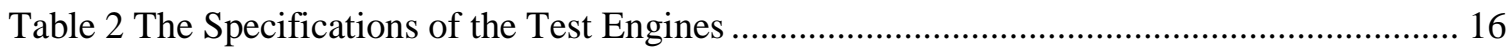

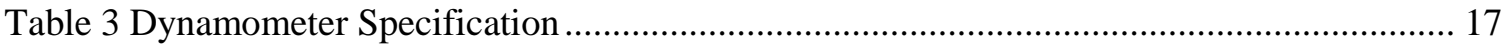

Table 4 Exhaust Gas Analyzer Specifications........................................................................... 19

Table 5 Percentage Error of Measurement Instruments [Sierra Instrument, 2008; Meriam, 2010;

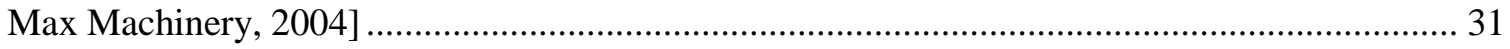

Table 6 Set Points for 13-Mode ESC, 1999 Cummins ISM370ESP ............................................ 33

Table 7 Constant Load Test Matrix for 1999 Cummins ISM370ESP, N=1200 RPM .................. 34

Table 8 Hydrogen Flow Rate at $\mathrm{H}_{2} /\left(\mathrm{H}_{2}+\right.$ Air $)=$ vol. $6 \%$ for 1999 Cummins ISM370ESP ............ 35

Table 9 Test Matrix for Constant Diesel Fuel Flow Rate, 1999 Cummins ISM370ESP .............. 37

Table 10 Test Matrix for Constant Torque with Variable Engine Speed, 1999 Cummins

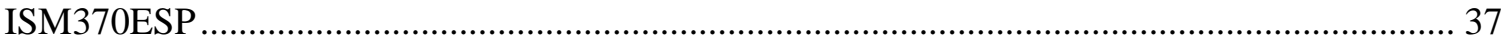

Table 11 Repeatability of $\mathrm{NO}_{\mathrm{x}}$ Exhaust Emissions Measured Using 13-Mode ESC, g/bhp-hr .... 38

Table 12 Repeatability of $\mathrm{NO}_{\mathrm{x}}$ Exhaust Emissions of Each Mode Measured Using 13-Mode

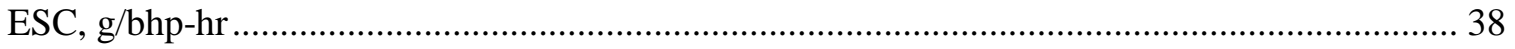

Table 13 Comparison of Diesel Flow Rate Measured Using 13-Mode ESC ............................... 39

Table 14 Effect of $\mathrm{H}_{2}$ Addition on Exhaust Emissions Measured Using 13-Mode ESC, g/bhp-hr40

Table 15 Effect of $\mathrm{H}_{2}$ Addition on SOI, SOC, and Ignition Delay (ID) When Operated at 1200 RPM, 70\% Load.

Table 16 Effect of $\mathrm{H}_{2}$ Addition on the SOI, SOC, and Ignition Delay When Operated at 1200

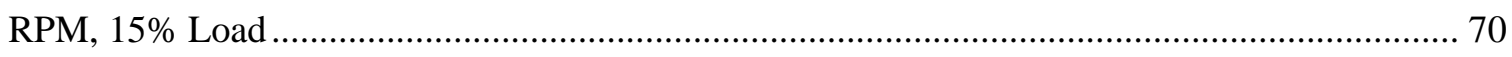

Table 17 Set Points for 13-Mode ESC, 2004 Mack MP7 355E ................................................... 74

Table 18 Constant Load Test Matrix for 2004 Mack MP7 355E, N=1200 RPM ........................ 75

Table 19 Test Matrix for Constant Diesel Fuel Flow Rate, 2004 Mack MP7 355E ..................... 75

Table 20 Effect of $\mathrm{H}_{2}$ Addition on Exhaust Emissions Measured using 13-Mode ESC, g/bhp-hr 77

Table 21 Effect of $\mathrm{H}_{2}$ Addition on $\mathrm{NO}_{\mathrm{x}}$ Emissions of a 2004 Mack MP7 355E and a 1999

Cummins ISM370ESP Engine Measured Using 13-Mode ESC, g/bhp-hr 78 
Table 22 Effect of $\mathrm{H}_{2}$ Addition on SOI, SOC, and Ignition Delay When Operated at 1200 RPM, $70 \%$ Load

Table 23 Effect of $\mathrm{H}_{2}$ Addition on SOI, SOC, and Ignition Delay When Operated at 1200 RPM, $15 \%$ Load .

Table 24 Effect of $\mathrm{H}_{2}$ Addition on SOI, SOC, and Ignition Delay When Operated at 1200 RPM,

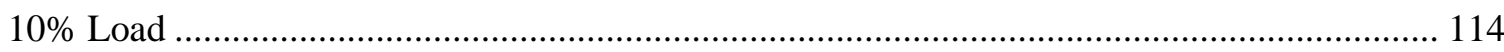




\section{TABLE OF FIGURES}

Figure 1 Effect of $\mathrm{H}_{2}$ Addition on Fuel Conversion Efficiency at 2500 RPM [McWilliam et al., 2008].

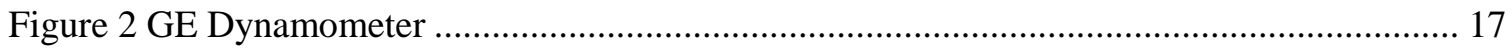

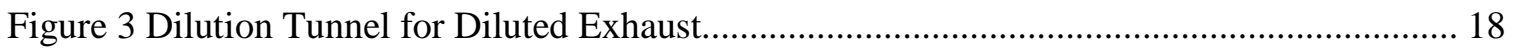

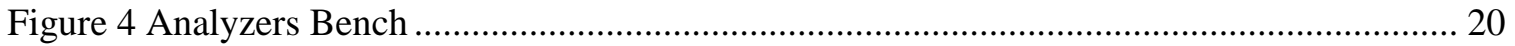

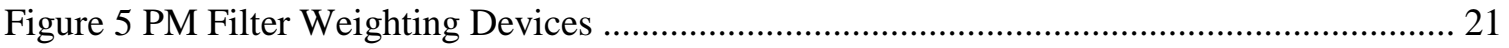

Figure 6 Schematic Diagram of $\mathrm{H}_{2}$ Fuel System...................................................................... 22

Figure 7 Hydrogen Station with Pressure Regulation Module and Emergency Valve A.............. 23

Figure 8 Hydrogen Fuel Metering and Control System with Safety Devices and Emergency Valve B 24

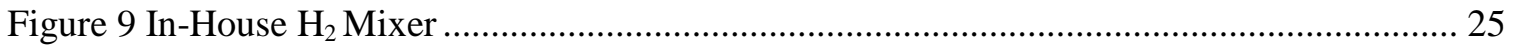

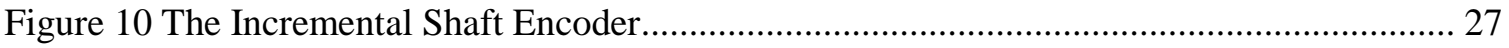

Figure 11 Instrumentation Control and Data Acquisition Bench ............................................... 28

Figure 12 Effect of Flame Arrester on Engine Map of the 2004 Mack MP7 355E Engine .......... 29

Figure 13 Effect of $\mathrm{H}_{2}$ Addition and Engine Load on BTE for 2004 Mack MP7 355E, N=1200

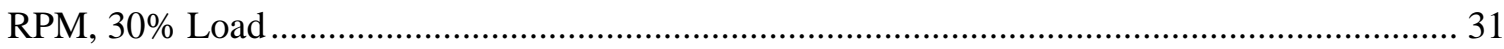

Figure 14 Set Points for 13-Mode ESC Emission Testing ........................................................... 32

Figure 15 Effect of $\mathrm{H}_{2}$ Addition on $\mathrm{H}_{2}$ Equivalence Ratio, 1999 Cummins ISM370ESP ............ 34

Figure 16 Effect of $\mathrm{H}_{2}$ Addition on Diesel Substitution, 1999 Cummins ISM370ESP, N=1200

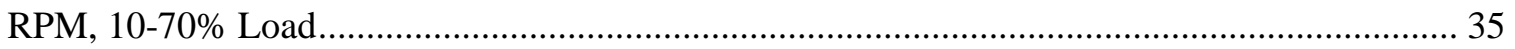

Figure 17 Effect of $\mathrm{H}_{2}$ Addition on Diesel Fuel Equivalence Ratio, 1999 Cummins ISM370ESP,

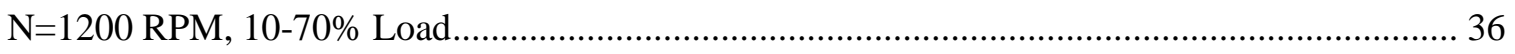

Figure 18 Effect of $\mathrm{H}_{2}$ Addition on Total Equivalence Ratio, 1999 Cummins ISM370ESP,

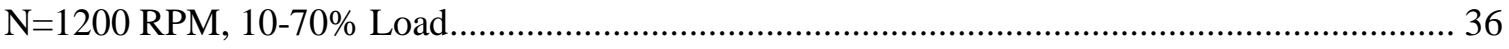

Figure 19 Repeatability of $\mathrm{NO}_{\mathrm{x}}$ Emissions of Each Mode Measured During 13-Mode ESC, g/bhphr. 39

Figure 20 Effect of $\mathrm{H}_{2}$ Addition on $\mathrm{NO}_{\mathrm{x}}$ Emissions, 13-Mode ESC .......................................... 40

Figure 21 Effect of $\mathrm{H}_{2}$ Addition on CO Emission, 13-Mode ESC ............................................. 41 
Figure 22 Effect of $\mathrm{H}_{2}$ Addition on HC Emissions, 13-Mode ESC ........................................... 42

Figure 23 Effect of $\mathrm{H}_{2}$ Addition on $\mathrm{CO}_{2}$ Emissions, 13-Mode ESC ......................................... 42

Figure 24 Effect of $\mathrm{H}_{2}$ Addition on $\mathrm{NO}_{\mathrm{x}}$ Emissions, $\mathrm{N}=1200$ RPM, 30-70\% Load .................... 43

Figure 25 Effect of $\mathrm{H}_{2}$ Addition on $\mathrm{NO}_{\mathrm{x}}$ Emissions and Maximum Average Bulk Mixture Temperature Calculated Using Cylinder Pressure, N=1200 RPM, 70\% Load............................. 44

Figure 26 Effect of $\mathrm{H}_{2}$ Addition on the Emissions of $\mathrm{NO}_{x}, \mathrm{NO}$, and $\mathrm{NO}_{2}, \mathrm{~N}=1200 \mathrm{RPM}, 70 \%$

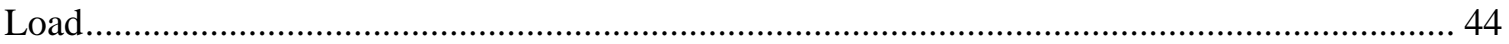

Figure 27 Effect of $\mathrm{H}_{2}$ Addition on $\mathrm{NO}_{\mathrm{x}}$ Emissions, $\mathrm{N}=1200$ RPM, 10-20\% Load ..................... 45

Figure 28 Effect of $\mathrm{H}_{2}$ Addition on $\mathrm{NO}_{\mathrm{x}}$ Emissions (mass) and Maximum Average Bulk Mixture

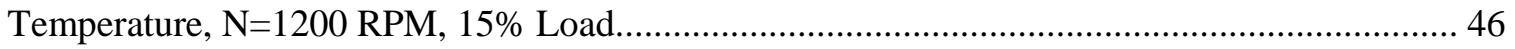

Figure 29 Effect of $\mathrm{H}_{2}$ Addition on the Emissions of $\mathrm{NO}_{x}, \mathrm{NO}$, and $\mathrm{NO}_{2}, \mathrm{~N}=1200 \mathrm{RPM}, 15 \%$

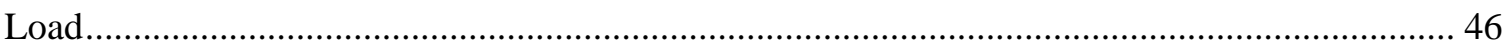

Figure 30 Effect of $\mathrm{H}_{2}$ Addition on $\mathrm{NO}_{\mathrm{x}}$ Emissions Operated with Constant Diesel Flow Rate of $22.45 \mathrm{~kg} / \mathrm{hr}$ (Corresponding to 50\% Load for Pure Diesel Operation). N=1200 RPM. For Constant Diesel Fuel Flow Rate Operation, Engine Load was varied by Adding $\mathrm{H}_{2}$.................. 47

Figure 31 Effect of $\mathrm{H}_{2}$ Addition on PM Emissions, N=1200 RPM, 30-70\% Load...................... 48

Figure 32 Effect of $\mathrm{H}_{2}$ Addition on PM Emissions, N=1200 RPM, 10-20\% Load....................... 49

Figure 33 Effect of $\mathrm{H}_{2}$ Addition on CO Emissions, N=1200 RPM, 10-20\% Load...................... 50

Figure 34 Effect of $\mathrm{H}_{2}$ Addition on CO Emissions, N=1200 RPM, 30-70\% Load...................... 50

Figure 35 Effect of $\mathrm{H}_{2}$ Addition on HC Emissions, N=1200 RPM, 10-20\% Load....................... 51

Figure 36 Effect of $\mathrm{H}_{2}$ Addition on HC Emissions, N=1200 RPM, 30-70\% Load...................... 51

Figure 37 Effect of $\mathrm{H}_{2}$ Addition on $\mathrm{CO}_{2}$ Emissions, N=1200 RPM, 10-70\% Load ...................... 52

Figure 38 Effect of $\mathrm{H}_{2}$ Addition on BTE and Its Improvements, N=1200 RPM, 30\% Load........ 53

Figure 39 Effect of $\mathrm{H}_{2}$ Addition and Engine Load on the Improvement to BTE, N=1200 RPM,

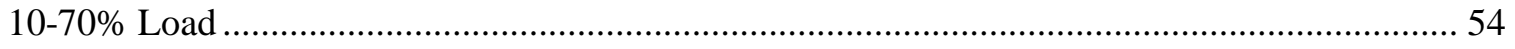

Figure 40 Effect of Engine Load on the Minimum $\mathrm{H}_{2}$ Supplementation Rate Needed for Positive

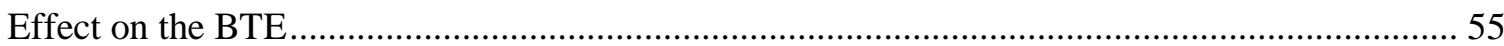

Figure 41 Effect of $\mathrm{H}_{2}$ Addition in Improving the BTE, N=1200 RPM, 10-70\% Load................ 55

Figure 42 Effect of Engine Load on the Improvement to BTE with the Addition of $6 \% \mathrm{H}_{2}$, $\mathrm{N}=1200 \mathrm{RPM}$ 56 
Figure 43 Effect of $\mathrm{H}_{2}$ Addition and Engine Speed on BTE and Improvement, Torque $=700 \mathrm{ft}-\mathrm{lb}$, Pure Diesel and $\mathrm{H}_{2} /\left(\mathrm{H}_{2}+\mathrm{Air}\right)=4 \%$, vol. 56

Figure 44 Effect of $\mathrm{H}_{2}$ Addition on BTE, $\mathrm{N}=1200$ RPM for Constant Diesel Flow Operation, Engine Load Was Increased by the Addition of $\mathrm{H}_{2}$ 57

Figure 45 Effect of $\mathrm{H}_{2}$ Addition on Cylinder Pressure, N=1200 RPM, 70\% Load....................... 58

Figure 46 Effect of $\mathrm{H}_{2}$ Addition on Intake Manifold Pressure, N=1200 RPM, 70\% Load........... 59

Figure 47 Effect of $\mathrm{H}_{2}$ Addition on Peak Cylinder Pressure and Its Phasing, N=1200 RPM, 70\% Load... 59

Figure 48 Effect of $\mathrm{H}_{2}$ Addition on Heat Release Rate of Premixed Combustion, N=1200 RPM, $70 \%$ Load 61

Figure 49 Effect of $\mathrm{H}_{2}$ Addition on Heat Release Rate, N=1200 RPM, 70\% Load. 61

Figure 50 The Two-Stage Heat Release Process of Pure Diesel Operation, N=1200 RPM, 70\% Load...

Figure 51 The Three-Stage Heat Release Process of $\mathrm{H}_{2}$-Diesel Dual Fuel Engine, $\mathrm{N}=1200 \mathrm{RPM}$, $70 \%$ Load, $\mathrm{H}_{2} /\left(\mathrm{H}_{2}+\mathrm{Air}\right)=6 \%$, vol.

Figure 52 Effect of $\mathrm{H}_{2}$ Addition on Peak Heat Release Rate and Its Phasing, N=1200 RPM, 70\% Load.. 64

Figure 53 Effect of $\mathrm{H}_{2}$ Addition on Cylinder Pressure, N=1200 RPM, 30\% Load. 65

Figure 54 Effect of $\mathrm{H}_{2}$ Addition on Intake Manifold Pressure, N=1200 RPM, 30\% Load. 65

Figure 55 Effect of $\mathrm{H}_{2}$ Addition on Peak Cylinder Pressure and Its Phasing, N=1200 RPM, 30\% Load. 66

Figure 56 Effect of $\mathrm{H}_{2}$ Addition on Heat Release Rate, N=1200 RPM, 30\% Load. 66

Figure 57 Effect of $\mathrm{H}_{2}$ Addition on Peak Heat Release Rate and Its Phasing, N=1200 RPM, 30\% Load.

Figure 58 Effect of $\mathrm{H}_{2}$ Addition on Cylinder Pressure, N=1200 RPM, 15\% Load 68

Figure 59 Effect of $\mathrm{H}_{2}$ Addition on Peak Cylinder Pressure and Its Phasing, N=1200 RPM, 15\% Load...... 68

Figure 60 Effect of $\mathrm{H}_{2}$ Addition on Heat Release Rate, N=1200 RPM, 15\% Load. 69

Figure 61 Effect of $\mathrm{H}_{2}$ Addition on Peak Heat Release Rate and Its Phasing, N=1200 RPM, 15\% Load. 
Figure 62 Effect of Diesel Flow Rate on Peak Heat Release Rate of $\mathrm{H}_{2}$-Diesel Dual Fuel Engine, $\mathrm{N}=1200$ RPM, 15\% Load. 70

Figure 63 Effect of $\mathrm{H}_{2}$ Addition and Engine Load on the Peak Heat Release Rate, N=1200 RPM, 15 , 30, and $70 \%$ Load. 71

Figure 64 Effect of $\mathrm{H}_{2}$ Addition on Equivalence Ratio of the Diesel Fuels, 2004 Mack MP7 355E,

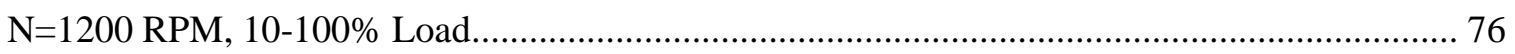

Figure 65 Effect of $\mathrm{H}_{2}$ Addition on Total Equivalence Ratio Including That of $\mathrm{H}_{2}$ and Diesel,

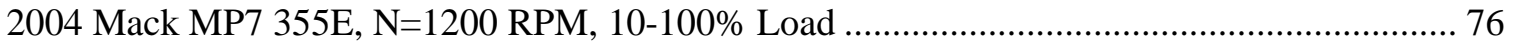

Figure 66 Effect of $\mathrm{H}_{2}$ Addition on $\mathrm{NO}_{\mathrm{x}}$ Emissions, 13-Mode ESC .......................................... 78

Figure 67 Effect of $\mathrm{H}_{2}$ Addition on CO Emissions, 13-Mode ESC ........................................... 79

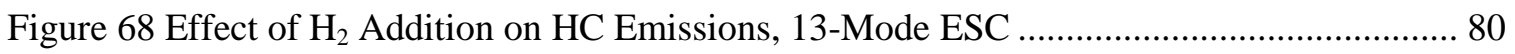

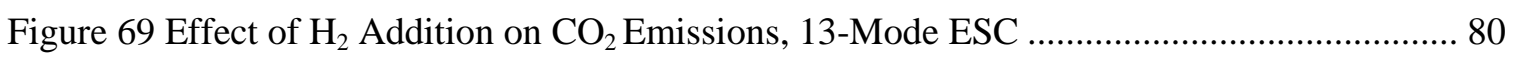

Figure 70 Effect of $\mathrm{H}_{2}$ Addition and Engine Load on $\mathrm{NO}_{\mathrm{x}}$ Emissions, N=1200 RPM, 10-20\% Load. 81

Figure 71 Effect of $\mathrm{H}_{2}$ Addition on $\mathrm{NO}_{\mathrm{x}}$ Emissions, $\mathrm{N}=1200$ RPM, 30\% Load........................... 82

Figure 72 Effect of $\mathrm{H}_{2}$ Addition on $\mathrm{NO}_{\mathrm{x}}$ Emissions, $\mathrm{N}=1200$ RPM, 50\% Load.......................... 83

Figure 73 Effect of $\mathrm{H}_{2}$ Addition on $\mathrm{NO}_{\mathrm{x}}$ Emissions and Intake Air Flow (liter per second (lps)) Measured Continuously, N=1200 RPM, 50\% Load.

Figure 74 Effect of $\mathrm{H}_{2}$ Addition and Engine Load on $\mathrm{NO}_{\mathrm{x}}$ Emissions, N=1200 RPM, 70\% Load84 Figure 75 Effect of $\mathrm{H}_{2}$ Addition and Engine Load on $\mathrm{NO}_{\mathrm{x}}$ Emissions, $\mathrm{N}=1200 \mathrm{RPM}, 100 \%$ Load 84

Figure 76 Effect of $\mathrm{H}_{2}$ Addition on the Emissions of $\mathrm{NO}_{x}, \mathrm{NO}$, and $\mathrm{NO}_{2}, \mathrm{~N}=1200 \mathrm{RPM}, 10 \%$ Load. 85

Figure 77 Effect of $\mathrm{H}_{2}$ Addition on the Emissions of $\mathrm{NO}_{x}, \mathrm{NO}$, and $\mathrm{NO}_{2}, \mathrm{~N}=1200 \mathrm{RPM}, 70 \%$ Load 85

Figure 78 Effect of $\mathrm{H}_{2}$ Addition on the Emissions of PM, N=1200 RPM, 70 and 100\% Load .... 86 Figure 79 Effect of $\mathrm{H}_{2}$ Addition on the Emissions of PM, N=1200 RPM, 50\% Load.................. 87 Figure 80 Effect of $\mathrm{H}_{2}$ Addition on the Emissions of PM, N=1200 RPM, 30\% Load.................. 87 Figure 81 Effect of $\mathrm{H}_{2}$ Addition on the Emissions of PM, N=1200 RPM, 10-20\% Load............. 88 Figure 82 Effect of $\mathrm{H}_{2}$ Addition on the Emissions of CO, N=1200 RPM, 10-50\% Load............. 89 
Figure 83 Effect of $\mathrm{H}_{2}$ Addition on the Emissions of CO, N=1200 RPM, 70-100\% Load. 89

Figure 84 Effect of $\mathrm{H}_{2}$ Addition on the Emissions of HC, N=1200 RPM, 10-100\% Load........... 90

Figure 85 Effect of $\mathrm{H}_{2}$ Addition on the Emissions of $\mathrm{CO}_{2}$, N=1200 RPM, 10-70\% Load........... 91

Figure 86 Effect of $\mathrm{H}_{2}$ Addition on Diesel Substitution for 2004 Mack MP7 355E, N=1200 RPM, 10-70\% Load 91

Figure 87 Effect of $\mathrm{H}_{2}$ Addition on the BTE, N=1200 RPM, 10\% Load................................... 92

Figure 88 Effect of $\mathrm{H}_{2}$ Addition on the BTE, N=1200 RPM, 20\% Load................................... 93

Figure 89 Effect of $\mathrm{H}_{2}$ Addition and Engine Load on BTE under Low Load Operation, N=1200 RPM, 10-30\% Load.

Figure 90 Effect of $\mathrm{H}_{2}$ Addition and Engine Load on BTE When Operated from Medium to High Load Operation, N=1200 RPM (For 100\% Operation, 2 and 4\% $\mathrm{H}_{2}$ Data Was Measured at 1225 RPM) 94

Figure 91 Effect of $\mathrm{H}_{2}$ Addition and Engine Load in Improving the BTE under Low Load Operation, N=1200 RPM, 10-30\% Load. 95

Figure 92 Effect of $\mathrm{H}_{2}$ Addition and Engine Load in Improving the BTE under Medium to High Load Operation, N=1200 RPM, 50-100\% Load 95

Figure 93 Effect of Engine Load on BTE Improvement with the Addition of $6 \% \mathrm{H}_{2}, \mathrm{~N}=1200$ RPM . 96

Figure 94 Effect of Engine Load on the Minimum $\mathrm{H}_{2}$ Supplementation Rate Needed for Positive Effect on BTE, N=1200 RPM 97

Figure 95 Effect of $\mathrm{H}_{2}$ Addition on the BTE, N=1200 RPM. For Constant Diesel Fuel Flow Rate (16.44 kg/hr) Operation, Engine Load Was Changed by the Addition of $\mathrm{H}_{2}$. 98

Figure 96 Effect of $\mathrm{H}_{2}$ Addition on the BTE, N=1200 RPM. For Constant Diesel Fuel Flow Rate

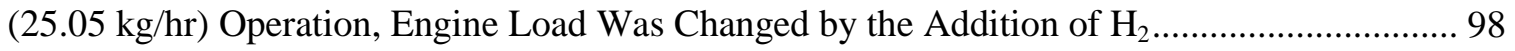

Figure 97 Effect of $\mathrm{H}_{2}$ Addition on Cylinder Pressure, N=1200 RPM, 70\% Load....................... 99

Figure 98 Effect of $\mathrm{H}_{2}$ Addition on Peak Cylinder Pressure and Its Phasing, N=1200 RPM, 70\% Load.. 99

Figure 99 Effect of $\mathrm{H}_{2}$ Addition on Premixed Combustion, N=1200 RPM, 70\% Load.............. 100

Figure 100 Effect of $\mathrm{H}_{2}$ Addition on Heat Release Process, N=1200 RPM, 70\% Load ............. 102

Figure 101 The Heat Release Process of $\mathrm{H}_{2}$-Diesel Dual Fuel Engine Operation, N=1200 RPM, $70 \%$ Load, $\mathrm{H}_{2} /\left(\mathrm{H}_{2}+\mathrm{Air}\right)=6 \%$, vol. 102 
Figure 102 Effect of $\mathrm{H}_{2}$ Addition on Peak Heat Release Rate and Its Phasing, N=1200 RPM, 70\%

Load. 103

Figure 103 Effect of $\mathrm{H}_{2}$ Addition on Cylinder Pressure, N=1200 RPM, 50\% Load. 104

Figure 104 Effect of $\mathrm{H}_{2}$ Addition on Peak Cylinder Pressure and Its Phasing, N=1200 RPM, 50\%

Load. 104

Figure 105 Effect of $\mathrm{H}_{2}$ Addition on Peak Heat Release Rate and Its Phasing, N=1200 RPM, 50\% Load... 105

Figure 106 Effect of $\mathrm{H}_{2}$ Addition Heat Release Rate, N=1200 RPM, 50\% Load, $\mathrm{H}_{2} /\left(\mathrm{H}_{2}+\mathrm{Air}\right)=5 \%$, vol. 106

Figure 107 Effect of $\mathrm{H}_{2}$ Addition on Heat Release Rate, N=1200 RPM, 50\% Load.................. 106

Figure 108 Effect of $\mathrm{H}_{2}$ Addition on Cylinder Pressure, N=1200 RPM, 30\% Load................... 107

Figure 109 Effect of $\mathrm{H}_{2}$ Addition on Peak Cylinder Pressure and Its Phasing, N=1200 RPM, 30\% Load. 108

Figure 110 Effect of $\mathrm{H}_{2}$ Addition on Heat Release Rate, N=1200 RPM, 30\% Load. 108

Figure 111 Effect of $\mathrm{H}_{2}$ Addition on Peak Heat Release Rate and Its Phasing, N=1200 RPM, 30\% Load. 109

Figure 112 Effect of $\mathrm{H}_{2}$ Addition on Cylinder Pressure, N=1200 RPM, 15\% Load. 110

Figure 113 Effect of $\mathrm{H}_{2}$ Addition on Peak Cylinder Pressure and Its Phasing, N=1200 RPM, 15\% Load. 110

Figure 114 Effect of $\mathrm{H}_{2}$ Addition on Heat Release Rate, N=1200 RPM, 15\% Load. 111

Figure 115 Effect of $\mathrm{H}_{2}$ Addition on Peak Heat Release Rate and Its Phasing, N=1200 RPM, 15\% Load......

Figure 116 Effect of $\mathrm{H}_{2}$ Addition on Cylinder Pressure, N=1200 RPM, 10\% Load..... 113

Figure 117 Effect of $\mathrm{H}_{2}$ Addition on Peak Cylinder Pressure and Its Phasing, N=1200 RPM, 10\% Load..

Figure 118 Effect of $\mathrm{H}_{2}$ Addition on Heat Release Rate, N=1200 RPM, 10\% Load..... 114

Figure 119 Effect of $\mathrm{H}_{2}$ Addition on Peak Heat Release Rate and Its Phasing, N=1200 RPM, 10\% Load. 114

Figure 120 Effect of Engine Load on Heat Release Process, N=1200 RPM, Diesel Only ... 115

Figure 121 Effect of Engine Load on Heat Release Process, N=1200 RPM, $\mathrm{H}_{2} /\left(\mathrm{H}_{2}+\mathrm{Air}\right)=6 \%$, vol. 116 


\section{NONMENCLATURE}

\begin{tabular}{|c|c|}
\hline $\mathrm{ADC}$ & Analog to Digital Converter \\
\hline B20 & Biodiesel 20 (a mixture composed of $20 \%$ of biodiesel with $80 \%$ of diesel) \\
\hline BMEP & Brake Mean Effective Pressure \\
\hline BSN & Bosch Smoke Number \\
\hline BTE & Brake Thermal Efficiency \\
\hline CAFEE & Center for Alternative Fuels, Engines and Emissions \\
\hline CEGR & Cooled Exhaust Gas Recirculation \\
\hline CFR & Code of Federal Regulations \\
\hline $\mathrm{CFV}$ & Critical Flow Venturi \\
\hline $\mathrm{CO}_{2}$ & Carbon Dioxide \\
\hline $\mathrm{CO}$ & Carbon Monoxide \\
\hline $\mathrm{COV}$ & Coefficient of Variation \\
\hline CVS & Constant Volume Sampler \\
\hline $\mathrm{DC}$ & Direct Current \\
\hline EERL & Engine and Emissions Research Laboratory \\
\hline EGR & Exhaust Gas Recirculation \\
\hline ESC & European Stationary Cycle \\
\hline ETC & European Transient Cycle \\
\hline ELR & European Load Response \\
\hline FSN & Filter Smoke Number \\
\hline GHG & Green House Gas \\
\hline $\mathrm{H}_{2}$ & Hydrogen \\
\hline $\mathrm{H}_{2} \mathrm{O}$ & Water \\
\hline $\mathrm{HC}$ & Hydrocarbon \\
\hline HP & Horsepower \\
\hline IC Engine & Internal Combustion Engine \\
\hline ID & Ignition Delay \\
\hline LFE & Laminar Flow Element \\
\hline NO & Nitric Oxide \\
\hline $\mathrm{NO}_{\mathrm{x}}$ & Oxides of Nitrogen \\
\hline
\end{tabular}




$\begin{array}{ll}\mathrm{NO}_{2} & \text { Nitrogen Dioxide } \\ \mathrm{O}_{2} & \text { Oxygen } \\ \mathrm{O} / \mathrm{C} & \text { Oxygen Carbon Ratio } \\ \mathrm{PM} & \text { Particulate Matter } \\ \mathrm{PO} & \text { Partial Oxidation } \\ \text { ppm } & \text { Parts per Million } \\ \text { REGR } & \text { Reformed Exhaust Gas Recirculation } \\ \text { RME } & \text { Rapeseed Methyl Ester } \\ \text { RPM } & \text { Revolution per Minute } \\ \text { SI Engine } & \text { Spark Ignition Engine } \\ \text { SCFM } & \text { Standard Cubic Feet per Minute } \\ \text { SME } & \text { Soy Methyl Ester } \\ \text { SMPS } & \text { Scanning Mobility Particle Sizing } \\ \text { SO } & \text { Sulfur Dioxide } \\ \text { SOC } & \text { Start of Combustion } \\ \text { SOI } & \text { Start of Injection } \\ \text { TDI } & \text { Turbocharged Direct Injection } \\ \text { UDDS } & \text { Urban Dynamometer Driving Schedule } \\ \text { ULSD } & \text { Ultra Low Sulfur Diesel } \\ \text { VGT } & \text { Variable Geometry Turbocharger } \\ \text { WVU } & \text { West Virginia University } \\ & \end{array}$




\section{INTRODUCTION}

\subsection{Introduction}

Hydrogen $\left(\mathrm{H}_{2}\right)$ has long been recognized as a carbon-free fuel having excellent combustion characteristics compared to the hydrocarbon fuel for applications in internal combustion (IC) engines. The burning of $\mathrm{H}_{2}$ in air produces mainly water $\left(\mathrm{H}_{2} \mathrm{O}\right)$, small amount of oxides of nitrogen $\left(\mathrm{NO}_{\mathrm{x}}\right)$ when burned at excessive lean mixture, without fuelresourced particulate matter (PM) emissions due to the unique fuel composition without bearing any carbon. These features make $\mathrm{H}_{2}$ an excellent fuel for both traditional power production devices such as IC engines and the latest innovative power devices such as fuel cells. The application of $\mathrm{H}_{2}$ in these devices makes it possible to potentially meet the ever increasingly stringent emission regulation, including the possible elimination of the on-site green house gas (GHG) emissions. The concise statements and detailed discussions of the positive features of $\mathrm{H}_{2}$ as a fuel and the associated limitations to its wide application as fuel have been the subject of much research and many publications [Das, 1990; Furuhama, 1983; Karim, 2003; White et al., 2006]. The past research of $\mathrm{H}_{2}$ as fuel has focused mainly on its application in spark ignition (SI) engines utilizing its fast flame propagation properties. Hydrogen has also been demonstrated as a fuel being able to support a propagating flame with extremely lean mixture, which is a very attractive property of the $\mathrm{H}_{2}$ as a SI engine fuel.

Diesel engines are widely used in transportation and off-road vehicles due to their high power density and fuel conversion efficiency. However, the further development of advanced diesel engine technologies is facing significant challenges. These include the 
requirements of simultaneously reducing the exhaust emissions of both $\mathrm{NO}_{\mathrm{x}}$ and $\mathrm{PM}$. In principle, $\mathrm{NO}_{\mathrm{x}}$ is formed under high combustion temperature and oxygen $\left(\mathrm{O}_{2}\right)$-rich operating conditions [Heywood, 1988]. The approaches tending to reduce the combustion temperature will reduce the engine out $\mathrm{NO}_{\mathrm{x}}$ emissions. In comparison, $\mathrm{PM}$ is formed in a diesel engine due mainly to the heterogeneous combustion characteristics of diesel engine. The presence of a fuel rich mixture under high temperature and pressure enhance the formation of PM. The approaches that help to improve the fuel vaporization and mixing process can reduce the formation of PM and correspondingly reduce PM emissions. The application of cooled exhaust gas recirculation (CEGR) has been demonstrated as an effective approach that can significantly reduce $\mathrm{NO}_{\mathrm{x}}$ emissions. However, the application of EGR increases the PM emissions, especially under high load operation.

Hydrogen as fuel can also be burned in compression ignition (CI) engines using a $\mathrm{H}_{2}$-diesel dual fuel combustion mode with $\mathrm{H}_{2}$ or $\mathrm{H}_{2}$-rich syngas supplemented to the intake mixture. At the end of the compression stroke, the compressed hot $\mathrm{H}_{2}$-air mixture is ignited by a pilot diesel spray. Such a dual fuel combustion mode has been demonstrated as an efficient and reliable approach of burning $\mathrm{H}_{2}$ in CI engines. Extensive research has been conducted using small single cylinder diesel engines and multi-cylinder light-duty diesel engines to investigate the effect of the addition of $\mathrm{H}_{2}$ on the performance, combustion, and emissions characteristics of CI engines [Bika et al., 2008; and Varde and Frame, 1983]. These include the brake thermal efficiency (BTE), heat release process, exhaust emissions of $\mathrm{NO}_{\mathrm{x}}, \mathrm{PM}, \mathrm{CO}, \mathrm{CO}_{2}$ and $\mathrm{HC}$. However, these criteria have not been reported in heavy-duty diesel engines application yet. 


\subsection{Objective}

The objective of this research was to investigate the effect of $\mathrm{H}_{2}$ addition on combustion and emission characteristics of heavy-duty diesel engines. The effects of the $\mathrm{H}_{2}$ addition, engine load, engine speed, and the diesel fuel flow rate on the engine performance, combustion process, and exhaust emissions have been explored. 


\section{LITERATURE REVIEW}

\subsection{Hydrogen Application as Fuel}

As a long time recognized carbon-free fuel, $\mathrm{H}_{2}$ can be used in traditional IC engines, gas turbines and also the fuel cells. Among these, the operation of the most fuel cells requires high quality pure $\mathrm{H}_{2}$. The presence of other components such as carbon monoxide (CO) and Sulfur Dioxide $\left(\mathrm{SO}_{2}\right)$ has been shown to deactivate the catalyst of fuel cells and reduce significantly the service life. Such an excessively demanding requirement for high purity $\mathrm{H}_{2}$ makes the operation of fuel cells economically uncompetitive though high thermal efficiency could be achieved without formation of pollutants. In comparison to fuel cells, IC engines can burn almost any low purity $\mathrm{H}_{2}$ even with the presence of quite a large amount of diluents. For example, the reformed gas containing mainly $\mathrm{H}_{2}$ with the presence of carbon dioxide $\left(\mathrm{CO}_{2}\right), \mathrm{CO}, \mathrm{H}_{2} \mathrm{O}$ and nitrogen $\left(\mathrm{N}_{2}\right)$, has been demonstrated as a suitable fuel showing $\mathrm{H}_{2}$-like desirable combustion properties [Li and Karim, 2005]. The application of $\mathrm{H}_{2}$ or its mixtures with traditional fuels also offers the opportunity of optimizing engine performance and reducing exhaust emissions.

\subsubsection{Application of $\mathrm{H}_{2}$ in SI Engines}

Hydrogen has long been recognized as a fuel having some unique and highly desirable properties, such as low ignition energy, very fast flame propagation speed, and wide lean operational range. The capability of $\mathrm{H}_{2}$ in supporting a propagating flame at extremely lean mixture was an attractive property of $\mathrm{H}_{2}$ as $\mathrm{SI}$ engine fuel. The extensive research on pure $\mathrm{H}_{2}$ as fuel has led to the development of the dedicated $\mathrm{SI}-\mathrm{H}_{2}$ engine. For 
example, Ford developed P2000 $\mathrm{H}_{2}$ engine, which was used to power Ford's E-450 Shuttle Bus [Gopalakrishnan et al., 2007; Stockhausen et al., 2002; and Tang et al., 2002]. BMW developed a 6 liter, $\mathrm{V}-12$ engine using liquid $\mathrm{H}_{2}$ as fuel [Kiesgen et al., 2006]. With an external mixture formation system, this engine has a power out about 170 $\mathrm{kW}$ and an engine torque of 340 N.m.

Most of the past research associated with $\mathrm{H}_{2}$ application in SI engines focused on its substitution to gasoline, a well known $\mathrm{H}_{2}$ enriching process. The extensive research in this area has demonstrated that $\mathrm{H}_{2}$ enriching helps to improve the performance of SI engine for the following reasons: (1) Enhancing the $\mathrm{H}_{2}$ flame propagation rate about 4 times that of traditional fuels. The addition of $\mathrm{H}_{2}$ to slow burning fuel enhanced substantially the flame propagation rate; (2) The addition of $\mathrm{H}_{2}$ to traditional fuels has been shown to extend the operational region toward the leaner mixture, which is very important to obtain extremely low $\mathrm{NO}_{\mathrm{x}}$ emissions; (3) Improving combustion stability (less cycle to cycle variation) and enhancing combustion efficiency benefiting from the reduced emissions of CO and hydrocarbon (HC). Detailed information can be found in the literature [Das, 1990; Karim, 2003; Li and Karim, 2005; Munshi et al., 2004; Topinka et al., 2004; and White et al., 2006].

\subsubsection{Application of $\mathrm{H}_{2}$ in Compression Ignition Engines as Sole Fuel}

Although the energy needed to ignite an $\mathrm{H}_{2}$-air mixture is much less than most hydrocarbon fuels, but the ignition temperature of $\mathrm{H}_{2}$ is much higher than other diesel fuel. Wong [1990] investigated the feasibility of using $\mathrm{H}_{2}$ as the sole fuel in a direct injection diesel engine. The engine combustion chamber was coated with ceramics to 
reduce the heat rejection from combustion chamber to coolant so as to increase the bulk gas temperature. By using a compression ratio of 17.9 to obtain a maximum compression temperature of approximately $900 \mathrm{~K}$, the lubrication oil was found to burn prior to that of $\mathrm{H}_{2}$ fuel. Only sporadic CI of $\mathrm{H}_{2}$ was achieved in a lower compression ratio of 17.1 and an engine speed of 1450 RPM. The ignition timing cannot be controlled and varied significantly under identical experimental conditions. It was concluded that the application of $\mathrm{H}_{2}$ as the sole fuel in direct injection diesel engine without an external ignition source, was neither practical nor feasible. A number of researchers demonstrated that it was necessary to employ a suitable ignition assistance device to ignite $\mathrm{H}_{2}$-air mixture in CI engine. The approaches tested included glow plug, spark assistance and pilot injection of diesel fuel to achieve reliable ignition of $\mathrm{H}_{2}$ in $\mathrm{CI}$ engines [Gopal et al., 1982; Ikegami et al., 1982; and Karim and Klat, 1982]. For example, Homan et al. [1979] demonstrated that it was very difficult to operate an $\mathrm{H}_{2}$ engine with just compression. However, the injection of pilot diesel fuel provided reliable ignition of $\mathrm{H}_{2}$. Furuhama and Fukuma [1986] developed a turbo-charged, two-stroke CI engine using $\mathrm{H}_{2}$ as the sole fuel. A hot surface igniter was developed to help the ignition of $\mathrm{H}_{2}$ supplied by direct incylinder injection. It was reported that such a hot surface igniter successfully ignited the $\mathrm{H}_{2}$ from low to full load operation.

\subsubsection{Application of $\mathbf{H}_{2}$ in Diesel Engines as Supplemental Fuels}

Considering the high temperature needed to ignite an $\mathrm{H}_{2}$-air mixture, external ignition resources is needed for the reliable, stable and repeatable ignition of $\mathrm{H}_{2}$-air mixtures. When burned in a CI engine, $\mathrm{H}_{2}$ was usually mixed with air in the intake manifold. At the end of the compression stroke, the $\mathrm{H}_{2}$-air mixture was ignited by a pilot 
diesel spray, which vaporized, mixed and reacted with $\mathrm{O}_{2}$ that contained in the $\mathrm{H}_{2}$-air mixture and finally ignited. The energy released from diesel combustion provided sufficient energy to initiate the ignition of $\mathrm{H}_{2}$ and its combustion. Such a dual fuel operation mode has been shown to be the most popular and stable combustion mode for gaseous fuels including $\mathrm{H}_{2}$ when used as a supplemental fuel in a diesel engine [Karim, 2003]. When burned in a $\mathrm{H}_{2}$-Diesel dual fuel engine, the $\mathrm{H}_{2}$-air mixture can be either burned through flame propagation like a SI engine if the $\mathrm{H}_{2}$-air mixture is rich enough to support the propagation of the flame; or the $\mathrm{H}_{2}$ can be burned through oxidation of $\mathrm{H}_{2}$ in air if a $\mathrm{H}_{2}$-air mixture was leaner than flammability limit. For example, Gopal et al. [1982] investigated the effect of the addition of $\mathrm{H}_{2}$ on the combustion and emission of a single cylinder diesel engine. It was shown that the addition of $\mathrm{H}_{2}$ to diesel fuel increased the energy release rate of the premixed combustion and thereby improved the thermal efficiency. The detailed information of dual fuel engine combustion process could be found in the literature [Boehman and Corre, 2008; and Karim, 2003].

\subsection{Literature Review of $\mathbf{H}_{2}$-Diesel Dual Fuel Engine 2.2.1 Emissions of $\mathrm{NO}_{\mathrm{x}}$}

Many $\mathrm{H}_{2}$-diesel dual fuel research projects expressed their wishes to reduce the emissions of $\mathrm{NO}_{\mathrm{x}}$ through the substitution of diesel fuel with $\mathrm{H}_{2}$. However, the research results reported in the literature did not support the expectations. For example, Varde and Frame [1983] reported some of the earlier work in examining the effect of the $\mathrm{H}_{2}$ addition on diesel combustion and emissions. They used a single cylinder small diesel engine with a rated power of $5 \mathrm{~kW}$. The addition of $\mathrm{H}_{2}$ to this diesel engine increased the emissions of $\mathrm{NO}_{\mathrm{x}}$ especially when operated under full load. For example, the $\mathrm{NO}_{\mathrm{x}}$ emissions increased 
almost linearly from about $900 \mathrm{ppm}$ for pure diesel operation to about $1150 \mathrm{ppm}$ with $15 \%$ of diesel substituted by $\mathrm{H}_{2}$ when operated at $82 \%$ load. In addition, the $\mathrm{NO}_{\mathrm{x}}$ emissions increased from $750 \mathrm{ppm}$ approximately linearly to $950 \mathrm{ppm}$ when $17 \%$ of diesel fuel was substituted.

Kumar et al. [2003] investigated the effect of the $\mathrm{H}_{2}$ addition on $\mathrm{NO}_{\mathrm{x}}$ emissions of a single cylinder, four stroke, diesel engine with a rated power of $3.7 \mathrm{~kW}$. For both standard diesel and Jatropha oil as main fuel, the addition of $\mathrm{H}_{2}$ increased the emissions of $\mathrm{NO}_{\mathrm{x}}$ when operated under high load. In comparison, the addition of $\mathrm{H}_{2}$ had negligible effect on $\mathrm{NO}_{\mathrm{x}}$ emissions when operated at low to medium load $(<60 \%)$. This was consistent with the $\mathrm{NO}_{\mathrm{x}}$ emission trends obtained in a 0.64 liter, single cylinder, directinjection diesel engine [Tomita, et al., 2001]. In this experiment, the overall equivalence ratio was kept as constant with the substitution of up to $80 \%$ diesel by $\mathrm{H}_{2}$. It was reported that the substitution of diesel by up to $70 \%$ of $\mathrm{H}_{2}$ had negligible effect on $\mathrm{NO}_{\mathrm{x}}$ emissions for low to medium load operation with overall equivalence ratio value of 0.3 and 0.4 , respectively. However, the substitution of diesel fuels with $\mathrm{H}_{2}$ increased the emissions of $\mathrm{NO}_{\mathrm{x}}$ from $200 \mathrm{ppm}$ for pure diesel operation to $450 \mathrm{ppm}$ when operated at overall equivalence ratio of 0.5 . It seems that the engine operating load may dominate the enhancing effect of the $\mathrm{H}_{2}$ addition on the variation of $\mathrm{NO}_{\mathrm{x}}$ emissions.

Saravanan and Nagarajan [2008] reported differently trend in examining the effect of engine load and the addition $\mathrm{H}_{2}$ on $\mathrm{NO}_{\mathrm{x}}$ emissions using a single cylinder, four-stroke diesel engine with a rated power of $3.7 \mathrm{~kW}$. The addition of 10 and $20 \% \mathrm{H}_{2}$ into the diesel engine increased the emissions of $\mathrm{NO}_{\mathrm{x}}$ measured in the examined load range. However, the $\mathrm{NO}_{\mathrm{x}}$ emissions decreased with further increase in the amount of diesel fuel 
substituted by $\mathrm{H}_{2}\left(>30 \% \mathrm{H}_{2}\right.$ substitution) when operated at $60 \%$ load. A minimum $\mathrm{NO}_{\mathrm{x}}$ emissions level of 575 ppm was achieved when $90 \%$ of diesel was substituted by $\mathrm{H}_{2}$.

It should be noted that most of the $\mathrm{H}_{2}$-diesel dual fuel engine research was conducted using single cylinder small diesel engines, which were designed without using the advanced diesel engine technologies. The exhaust emissions were measured at constant speed with a number of different loads without following emission measurement cycles specified in national or international emission regulations. For example, the emissions of $\mathrm{NO}_{\mathrm{x}}$ were reported in concentration (ppm) other than those presented in specific rate such as $\mathrm{g} / \mathrm{kW}$-h or equivalent. This made it difficult to evaluate the compliance of these engines with past and current emission regulations.

Recently, some interests rises on examined the effect of $\mathrm{H}_{2}$ addition on exhaust emissions using specific emission measurement cycle. For example, Tsolakis, et al. [2005] investigated the effect of $\mathrm{H}_{2}$-rich gases on the exhaust emissions of a single cylinder diesel engine measured at 9 different engine operating conditions, which were part of the 13-mode European Stationary Cycle (ESC). The addition of $\mathrm{H}_{2}$-riches syngas was found to reduce the emissions of $\mathrm{PM}$ and $\mathrm{NO}_{\mathrm{x}}$. More recently, a number of research studies were conducted using light-duty multi-cylinder diesel engines with modern engine technologies following the modern emission measurement approach. For example, Bika et al. [2008] examined the effect of $\mathrm{H}_{2}$ addition on $\mathrm{NO}_{\mathrm{x}}$ emissions of a 1999 Volkswagen 4 cylinder, 1.9 L, turbocharged direct injection (TDI) diesel engine. The addition of $\mathrm{H}_{2}$ for the substitution up to $40 \%$ of total energy had negligible effect on $\mathrm{NO}_{\mathrm{x}}$ emissions reported in ppm. The addition of $\mathrm{H}_{2}$ into diesel engine increased the nitrogen dioxide $\left(\mathrm{NO}_{2}\right) / \mathrm{NO}_{\mathrm{x}}$ ratio especially under low load operation. Shirk et al. [2008] 
examined the effect of $\mathrm{H}_{2}$ supplementation on exhaust emissions of a modern production 1.3 L, turbo-charged, light-duty diesel engine with a common-rail fuel system. When installed in the engine test cell, eight steady state operating points were tested with $\mathrm{H}_{2}$ flow rate equivalent to 0,5 , and $10 \%$ of the total fuel energy. The addition of $\mathrm{H}_{2}$ was shown to slightly increase the emissions of $\mathrm{NO}_{\mathrm{x}}$. However, its effect on the thermal efficiency was small. This engine was also installed in a 2005 Chevrolet Equinox and tested on a chassis dynamometer following the Urban Dynamometer Driving Schedule (UDDS) and 505 urban driving cycles. The addition of $5 \% \mathrm{H}_{2}$ showed negligible effect on $\mathrm{NO}_{\mathrm{x}}$ emissions. However, the substitution of $10 \%$ diesel by $\mathrm{H}_{2}$ reduced the $\mathrm{NO}_{\mathrm{x}}$ emission rate from 0.75 to $0.6 \mathrm{~g} /$ mile, a $20 \%$ reduction compared to diesel operation.

Exhaust gas recirculation (EGR) has been widely used in modern diesel engines to reduce the engine-out $\mathrm{NO}_{\mathrm{x}}$ emissions. For example, McWilliam et al. [2008] investigated the effects of $\mathrm{H}_{2}$ addition on the combustion and emissions of a modern 2.0 L, turbo-charged, 4 cylinders, four stroke diesel engine with EGR. The effects of engine load, EGR rate and the addition of $\mathrm{H}_{2}$ on exhaust emissions were experimentally investigated. The $\mathrm{NO}_{\mathrm{x}}$ emissions data were reported in $\mathrm{g} / \mathrm{kW}$-hr. The addition of $\mathrm{H}_{2}$ into this light-duty diesel engine increased substantially the emissions of $\mathrm{NO}_{\mathrm{x}}$ especially for low load operation without EGR. When operated at 2.7 brake mean effective pressure (BMEP), the emissions of $\mathrm{NO}_{\mathrm{x}}$ were increased almost linearly from 6.1 to $19.2 \mathrm{~g} / \mathrm{kW}$-hr with the addition of $6 \% \mathrm{H}_{2}$. In comparison, the emissions of $\mathrm{NO}_{\mathrm{x}}$ were $5.3 \mathrm{~g} / \mathrm{kW}$-hr when operated with pure diesel operation at $10 \%$ of EGR. With the addition of $6 \% \mathrm{H}_{2}$, the emissions of $\mathrm{NO}_{\mathrm{x}}$ were $12.0 \mathrm{~g} / \mathrm{kW}$-hr, which was 2.2 times that of pure diesel engine operation. With the help of EGR, it was possible to obtain lower $\mathrm{NO}_{\mathrm{x}}$ emissions with the 
addition of $\mathrm{H}_{2}$. The researchers also tested similar criteria but higher load was applied. With the help of $\mathrm{H}_{2}$ as supplemental fuel, it was possible to develop suitable engine operation strategies that could substantially reduce the emissions of $\mathrm{NO}_{\mathrm{x}}$ while overcoming the penalty in fuel economies when EGR was employed.

\subsubsection{Emissions of PM}

Particulate matter has continued to be one of the problematic pollutants associated with diesel engines since the stringent emission control standards were implemented. In the early decades of $\mathrm{H}_{2}$-diesel dual fuel emissions research, the PM emissions were usually qualitatively measured using simple smoke meters such as the devices developed by AVL and Bosch. The PM emissions were reported as Filter Smoke Number (FSN) or Bosch Smoke Number (BSN). For example, Varde and Frame [1983] examined the effect of $\mathrm{H}_{2}$ substitution to diesel fuel on PM emissions using an air-cooled single cylinder diesel engine. The smoke level was reduced when a small percentage of diesel was substituted by $\mathrm{H}_{2}$ until the minimum PM emissions were observed. Beyond the limit, increasing further in $\mathrm{H}_{2}$ flow rate produced more $\mathrm{PM}$ as represented by the increased BSN number. This was due to the displacement of air by $\mathrm{H}_{2}$, which reduced the overall air/fuel ratio of diesel fuel and resulted in increased formation of PM. Tomita et al. [2001] examined the PM emissions of a $0.64 \mathrm{~L}$, single cylinder, direct-injection, diesel engine supplemented with $\mathrm{H}_{2}$ while using a Bosch type smoke meter (Zexel, DSM10). The addition of $\mathrm{H}_{2}$ to this small diesel engine was demonstrated to reduce the smoke emission level especially when operating at higher load (60\% of load). 
Recently, some research was conducted using light-duty multi-cylinder diesel engines. For example, McWilliam et al. [2008] examined the effect of $\mathrm{H}_{2}$ addition on the PM emissions through measuring variation of FSN of a turbo-charged diesel engine. The addition of $\mathrm{H}_{2}$ into the diesel engine reduced substantially the PM emissions especially when operated at high load without EGR. Bika et al. [2008] examined the effect of $\mathrm{H}_{2}$ addition on PM emissions of a 1.9 L Volkswagen TDI engine. The PM emissions were measured using a Scanning Mobility Particle Sizer (SMPS). The amount of $\mathrm{H}_{2}$ added varied from $10-40 \%$ when evaluated on the total intake energy basis. For all load conditions examined, the addition of $\mathrm{H}_{2}$ reduced the $\mathrm{PM}$ emissions ranging from 10 to 50\% in both total PM concentration and total PM number. Using the PM concentration, soot diameter distribution and the assumed density of $1 \mathrm{~g} / \mathrm{cm}^{3}$ of the spherical soot particles, the PM mass flow rate was calculated. This demonstrated that the addition of $\mathrm{H}_{2}$ into the diesel engine reduced the PM mass emissions beyond the amount expected from the reduction of diesel fuel flow rate.

Saravanan and Nagarajan [2008] reported PM emissions quantitatively using the gravimetric method with a single cylinder small diesel engine. The PM emissions were reported in $\mathrm{g} / \mathrm{kW}$-h. However, the approach to quantitatively measure the emissions of PM was not reported. The PM emissions were observed to reduce dramatically with the increased addition of $\mathrm{H}_{2}$. For example, the $\mathrm{PM}$ emissions were reduced by $70 \%$ with the substitution of $90 \%$ diesel by $\mathrm{H}_{2}$. Masood et al. [2007] examined the effect of compression ratio and $\mathrm{H}_{2}$ substitution ratio on $\mathrm{PM}$ emissions at full load operation using a single cylinder diesel engine with a rated power of $3.7 \mathrm{~kW}$. The PM emissions rated as $\mathrm{g} / \mathrm{m}^{3}$ were reported without describing the measurement method. As $\mathrm{H}_{2}$ substitution 
percentage increased from 10 to 90\%, the PM emissions reduce by $92.7 \%$ when operated at compression ratio of 18.35 .

\subsubsection{Emissions of $\mathrm{HC}, \mathrm{CO}$, and $\mathrm{CO}_{2}$}

The addition of $\mathrm{H}_{2}$ to a diesel engine has been demonstrated to reduce the exhaust emissions of $\mathrm{HC}, \mathrm{CO}$, and $\mathrm{CO}_{2}$. The literature data obtained from a number of diesel engines with different fuel mixing and engine technologies demonstrated the varying trend of $\mathrm{HC}, \mathrm{CO}$, and $\mathrm{CO}_{2}$ emissions. Most of the researchers reported the addition of $\mathrm{H}_{2}$ to diesel engine would reduce $\mathrm{HC}, \mathrm{CO}$, and $\mathrm{CO}_{2}$ emissions [Lambe and Watson, 1992; McWilliam et al., 2008; and Saravanan and Nagarajan, 2008]. For example, McWilliam et al. [2008] investigated the effects of $\mathrm{H}_{2}$ addition on $\mathrm{CO}$ emissions of a multi-cylinder light-duty diesel engine with EGR. The addition of $\mathrm{H}_{2}$ decreased substantially the emissions of CO especially for high load operation. When operated at 5.4 bmep, the emissions of CO decreased almost linearly from 24.0 to 9.50 $\mathrm{g} / \mathrm{kW}$-hr with the addition of $6 \% \mathrm{H}_{2}$. McWilliam et al. [2008] also investigated the effects of $\mathrm{H}_{2}$ addition on $\mathrm{HC}$ emissions but only reported in ppm concentration. The addition of $\mathrm{H}_{2}$ produced negligible amount of $\mathrm{HC}$ emission between 150 to $200 \mathrm{ppm}$ at 2.7 and 5.4 bmep, respectively. However, research conducted by Varde and Frame [1983] reported that both $\mathrm{CO}$ and $\mathrm{HC}$ emissions increased with $\mathrm{H}_{2}$ addition.

\subsubsection{Brake Thermal Efficiency}

Thermal efficiency is one of the main parameters associated with power and fuel economy. Most of the early research associated with the $\mathrm{H}_{2}$-diesel dual fuel engines evaluated the improvement of the engine efficiencies. For example, Varde and Frame 
[1983] examined the effect of $\mathrm{H}_{2}$ substitution on the brake thermal efficiency using a direct injection single cylinder diesel engine. With the addition of $\mathrm{H}_{2}$ into diesel engine, the brake thermal efficiency was found to increase significantly. When operated at full load, the BTE increased from $30.5 \%$ for pure diesel operation to $33.7 \%$ for dual fuel operation with $12.5 \%$ of the energy supplied by $\mathrm{H}_{2}$. However, the addition of small portion of $\mathrm{H}_{2}(<5 \%$ of total energy) into diesel engine reduced the BTE. It was believed that this was due to the extremely lean $\mathrm{H}_{2}$-air mixture, which cannot support the flame propagation and resulted in low combustion efficiency.

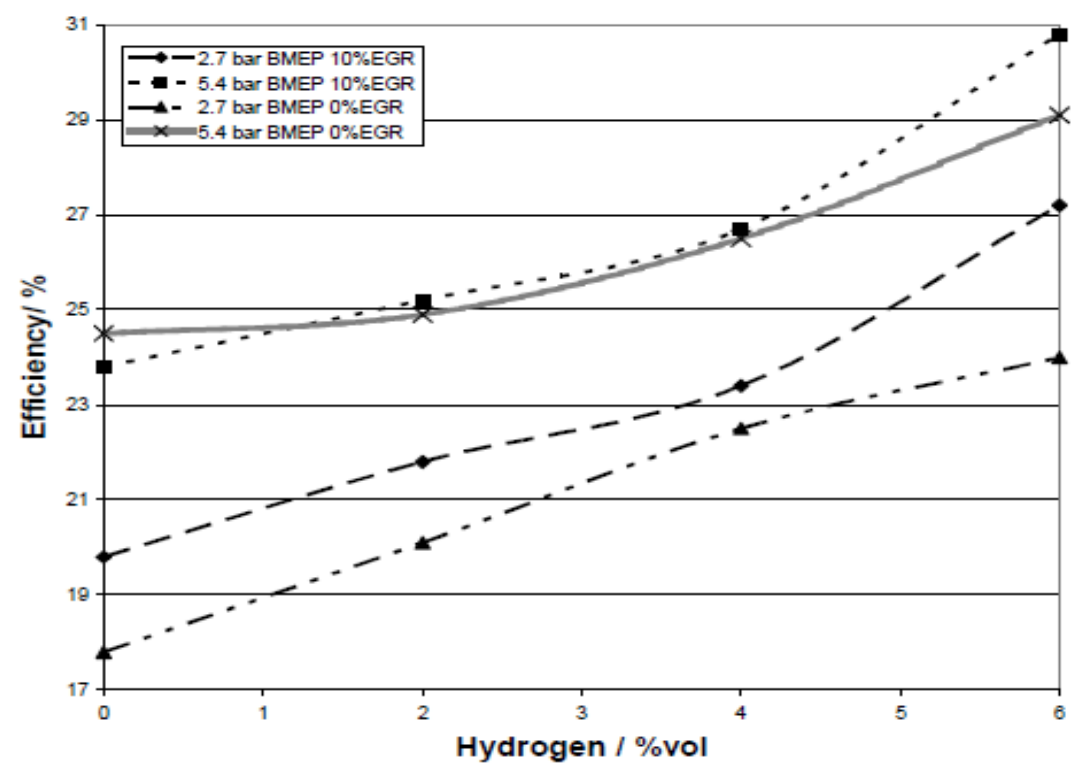

Figure 1 Effect of $\mathrm{H}_{2}$ Addition on Fuel Conversion Efficiency at 2500 RPM [McWilliam et al., 2008]

Recently, McWilliam et al. [2008] investigated the effect of $\mathrm{H}_{2}$ addition on the thermal efficiency of a light-duty diesel engine. As shown in Figure 1, the addition of $\mathrm{H}_{2}$ to this modern multi-cylinder diesel engine significantly improved the thermal efficiency. As shown in Table 1 for operation at 5.4 BMEP with 10\% EGR, the addition of $6 \% \mathrm{H}_{2}$ into intake manifold improved the thermal efficiency from $23.8 \%$ for pure diesel 
operation to $30.8 \%$, an improvement of $29.2 \%$. When operated at 2.7 BMEP, the brake thermal efficiency was increased by $37.4 \%$ with the addition of $6 \% \mathrm{H}_{2}$.

Table 1 Variation of Thermal Efficiency with the Addition of $\mathrm{H}_{2}$ [McWilliam et al., 2008]

\begin{tabular}{|c|c|c|c|}
\hline \multirow{2}{*}{$\begin{array}{c}\text { Load } \\
\text { (BMEP) }\end{array}$} & $\begin{array}{c}\mathrm{H}_{2} /\left(\mathrm{H}_{2}+\text { air }\right), \\
\%\end{array}$ & $\begin{array}{c}\text { Thermal } \\
\text { efficiency, } \%\end{array}$ & $\begin{array}{c}\text { Thermal efficiency } \\
\text { increase compared to that } \\
\text { of pure diesel operation, } \\
\%\end{array}$ \\
\hline \multirow{4}{*}{5.4} & 0 & 23.8 & 0 \\
\cline { 2 - 4 } & 2 & 25.2 & 5.78 \\
\cline { 2 - 4 } & 4 & 26.7 & 12.0 \\
\hline \multirow{4}{*}{2.7} & 6 & 30.8 & 29.2 \\
\cline { 2 - 4 } & 2 & 19.8 & 0 \\
\cline { 2 - 4 } & 4 & 21.8 & 10.1 \\
\cline { 2 - 4 } & 6 & 27.2 & 18.2 \\
\hline
\end{tabular}




\section{EXPERIMENTAL SETUP AND SAFETY APPROACH}

\subsection{Test Engines}

The Engine and Emissions Research Laboratory (EERL) of West Virginia University's (WVU) is located in Morgantown, West Virginia. The laboratory was built to meet the specification of CFR 40, Part 86 Subpart N [CFR (1), 1998]. The laboratory is facilitated with four engine test skids and two full flow dilution tunnels. In this research study, two class-8 heavy-duty diesel engines were used. The detail specifications of these test engines are shown in Table 2.

Table 2 The Specifications of the Test Engines

\begin{tabular}{|l|c|c|}
\hline Engine Manufacturer & Mack & Cummins \\
\hline Engine Model & MP7 355E & ISM370ESP \\
\hline Model Year & 2004 & 1999 \\
\hline Displacement & 10.8 Liter & 10.8 Liter \\
\hline Power Rating & 355 bhp @ 1800 RPM & bhp @ 2100 RPM \\
\hline Torque Rating & 1360 ft-lb @ 1200 RPM & 1350 ft-lb @ 1200 RPM \\
\hline Configuration & Inline 6-cylinder & Inline 6-cylinder \\
\hline Bore x Stroke & 4.84 in. x 5.98 in. & 4.92 in. x 5.79 in. \\
\hline Induction & Turbocharged with in-house & $\begin{array}{c}\text { Turbocharged with in-house } \\
\text { Aftercooler }\end{array}$ \\
\hline Fuel Type & Aftercooler & Diesel \\
\hline Engine Strokes per Cycle & 4 & 4 \\
\hline Injection & Direct Injection, Electronic & Direct Injection, Electronic \\
\hline Cooled EGR & Yes & No \\
\hline $\begin{array}{l}\text { Variable Geometry } \\
\text { Turbo Charger (VGT) }\end{array}$ & Yes & No \\
\hline
\end{tabular}




\subsection{Dynamometer}

The engine dynamometer was designed to absorb the load or output of the engine. When testing an engine in the test cell, a computer program was commanded the dynamometer to control the load of an engine. In this research, a 550 hp DC dynamometer manufactured by GE was used. The detailed of specification of the dynamometer can be found in Figure 2 and Table 3.

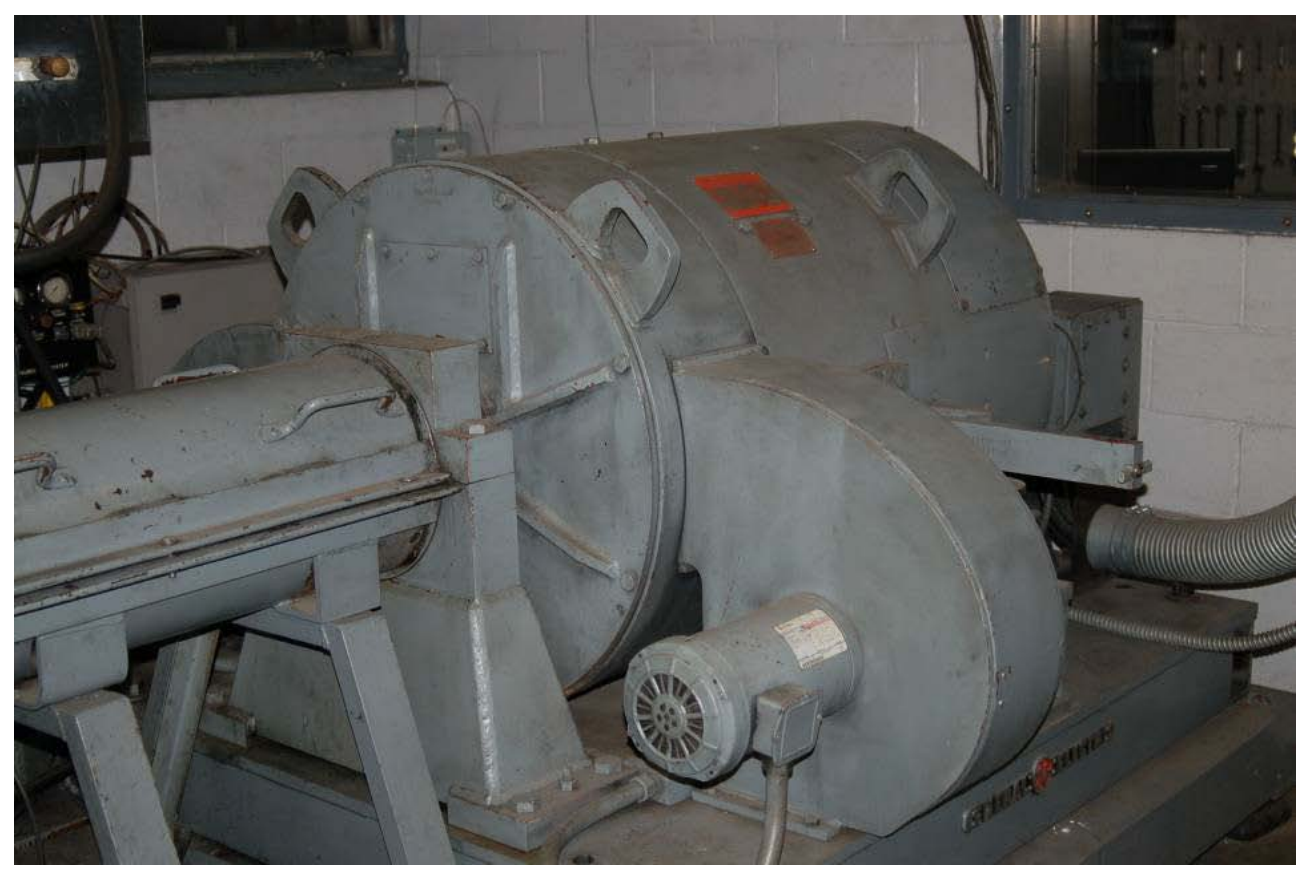

Figure 2 GE Dynamometer

Table 3 Dynamometer Specification

\begin{tabular}{|c|c|}
\hline Dynamometer Manufacturer & General Electric \\
\hline Model & DYC 243 \\
\hline Absorbing Capacity & 550 hp @ 474 V @ 812 amp \\
\hline Motoring Capacity & 500 hp @ 507 V @ 812 amp \\
\hline Current & Direct Current \\
\hline Serial Number & ZG-2-44-2G \\
\hline
\end{tabular}




\subsection{The Measurement of Exhaust Emissions}

\subsubsection{Dilution Tunnel}

The engine exhaust was ducted to a full-scale dilution tunnel (18 inches in diameter, 20 feet in length (Figure 3) with flow control accomplished using a critical flow venturi-constant volume sampler (CFV-CVS) system. A 10-inch diameter orifice located 3 feet from the tunnel entrance, ensured that exhaust was thoroughly mixed with dilution air before it reached the emissions sampling zone, located ten tunnel diameters downstream. The CFV-CVS controlled the dilute exhaust flow at a nominal 2400 standard cubic feet per minute (scfm) throughout the test program. Instantaneous measurement of CFV-CVS flow was accomplished using a fast-response thermocouple and pressure transducer at the venturi entrance. Dilute exhaust samples were drawn from the tunnel using heated sample probes and lines to individual emissions analyzers. Dilute exhaust was also drawn from the dilution tunnel sample plane through a series of two 70 mm filters to collect PM samples.

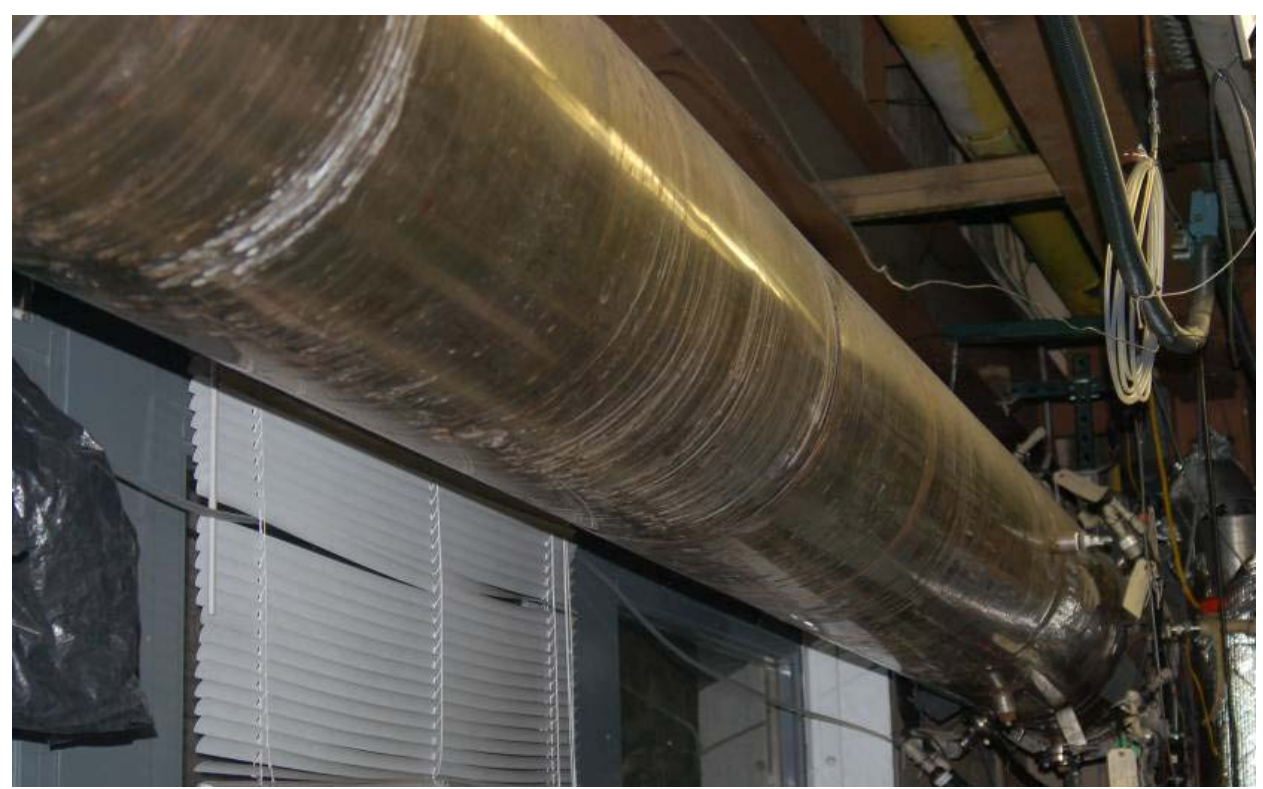

Figure 3 Dilution Tunnel for Diluted Exhaust 


\subsubsection{Measurement of Gases Emissions}

The WVU EERL is capable of measuring multiple types of exhaust gas emissions. The specification and setup of all analyzers are shown in Table 4 and Figure 4. The diluted exhaust was drawn from the full flow dilution tunnel into an insulated sample line that was connected to analyzers. Heated pumps were installed prior to the each analyzer in order to maintain the flow pressures and flow temperatures. Prior to the test, the analyzers were calibrated with specific gas concentration. In addition, span/zero, flow temperatures, and flow pressures were checked before and after each test. These procedures were conducted according to WVU Center for Alternative Fuels, Engines and Emissions (CAFEE) protocols per 40 CFR Part 86 Subpart N §1310-90 [CFR (2), 1998].

Table 4 Exhaust Gas Analyzer Specifications

\begin{tabular}{|c|c|c|c|}
\hline $\begin{array}{c}\text { Exhaust Gas } \\
\text { Constituent }\end{array}$ & $\begin{array}{c}\text { Measurement } \\
\text { Technology }\end{array}$ & Manufacturer & Model \\
\hline $\begin{array}{c}\text { Oxides of Nitrogen } \\
\left(\mathrm{NO}_{\mathrm{x}}\right)\end{array}$ & Chemiluminescence & Eco Physics & CLD822CMH \\
\hline Nitric Oxide (NO) & Chemiluminescence & Eco Physics & CLD822CMH \\
\hline $\begin{array}{c}\text { Hydrocarbon (HC) } \\
\text { Flame Ionization } \\
\text { Detection }\end{array}$ & $\begin{array}{c}\text { California } \\
\text { Analytical } \\
\text { Instruments }\end{array}$ & 600M HFID \\
\hline $\begin{array}{c}\text { Carbon Monoxide } \\
(\mathrm{CO})\end{array}$ & $\begin{array}{c}\text { Non-dispersive } \\
\text { infrared }\end{array}$ & Horiba & AIA-210 \\
\hline $\begin{array}{c}\text { Carbon Dioxide }\left(\mathrm{CO}_{2}\right) \\
\text { Particulate Matter } \\
(\mathrm{PM})\end{array}$ & $\begin{array}{c}\text { Non-dispersive } \\
\text { infrared }\end{array}$ & Hravimetric \\
Analysis & $\begin{array}{c}\text { PM Sampling } \\
\text { Accordance to } \\
40 \text { CFR Part } 86\end{array}$ & AIA-210 \\
\hline
\end{tabular}




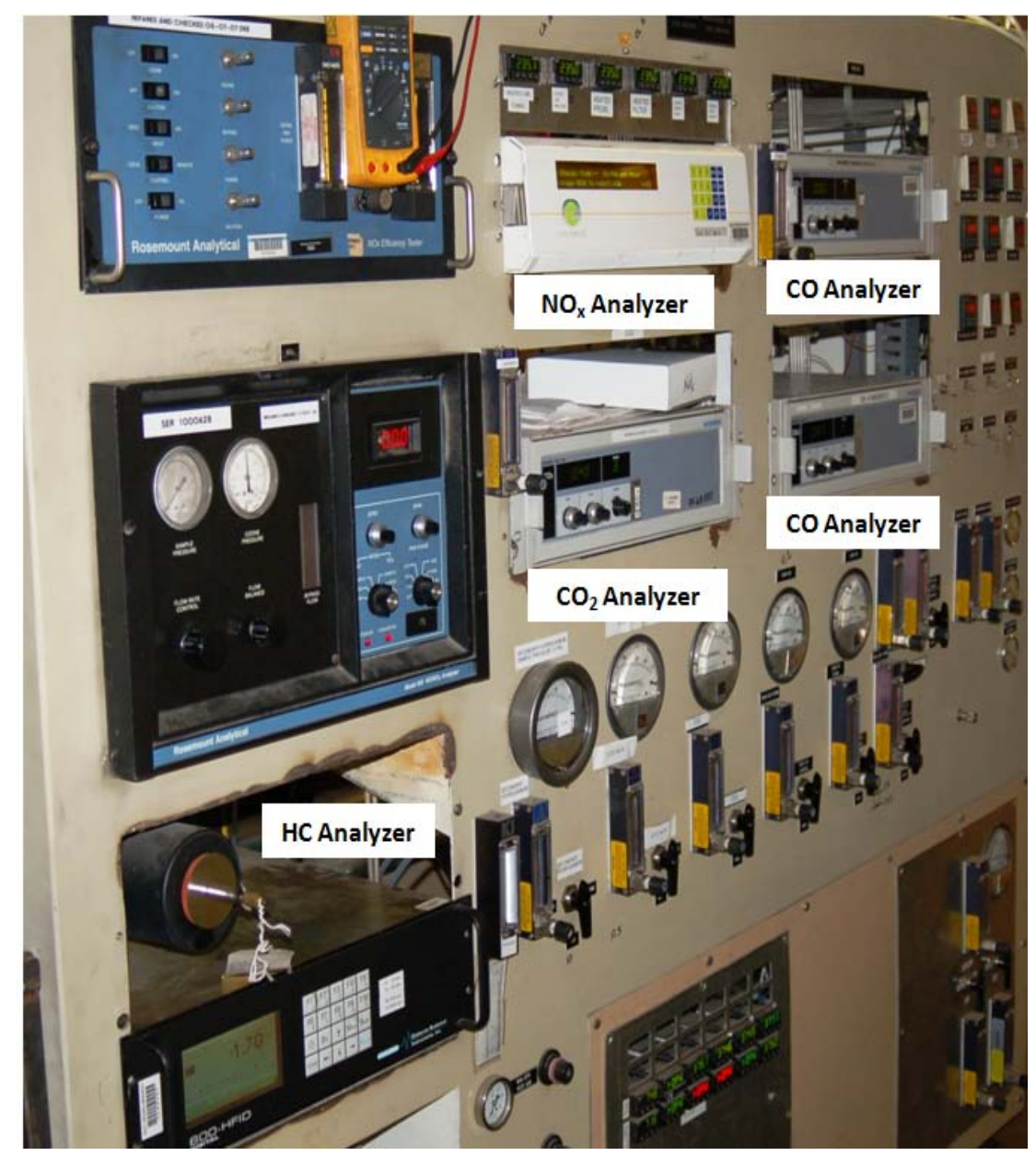

Figure 4 Analyzers Bench

\subsubsection{Measurement of PM Emissions}

PM was measured by the gravimetric method accordance to 40 CFR Part 86 Subpart N § 1312-88 [CFR (3), 1998]. Diluted exhaust was drawn from the full flow dilution tunnel into a stainless steel 4 inch diameter by 30 inch long secondary dilution tunnel and, then passes through a stainless steel filter holder that contained two Pallflex 70 mm diameter Model T60A20 fluorocarbon-coated glass microfiber filters in series. The sample stream was maintained at temperatures below $125^{\circ} \mathrm{F}$ as measured at the inlet of the PM filter holder. Secondary dilution air, which can be used to lower the 
temperature of the dilute sample upstream of the sample filters, was not required during this evaluation. Prior to weighing (both before and after PM measurement), sample filters were conditioned for at least an hour in an environmentally controlled room to a nominal $22{ }^{\circ} \mathrm{C}$ dry bulb, $9.5{ }^{\circ} \mathrm{C}$ dew point, and $45 \%$ relative humidity, in compliance with requirements presented in CFR 40, Part 86 Subpart N § 1312-88 [CFR (3), 1998]. Filters were weighed using a Sartorius microbalance in a controlled environment as shown in Figure 5.

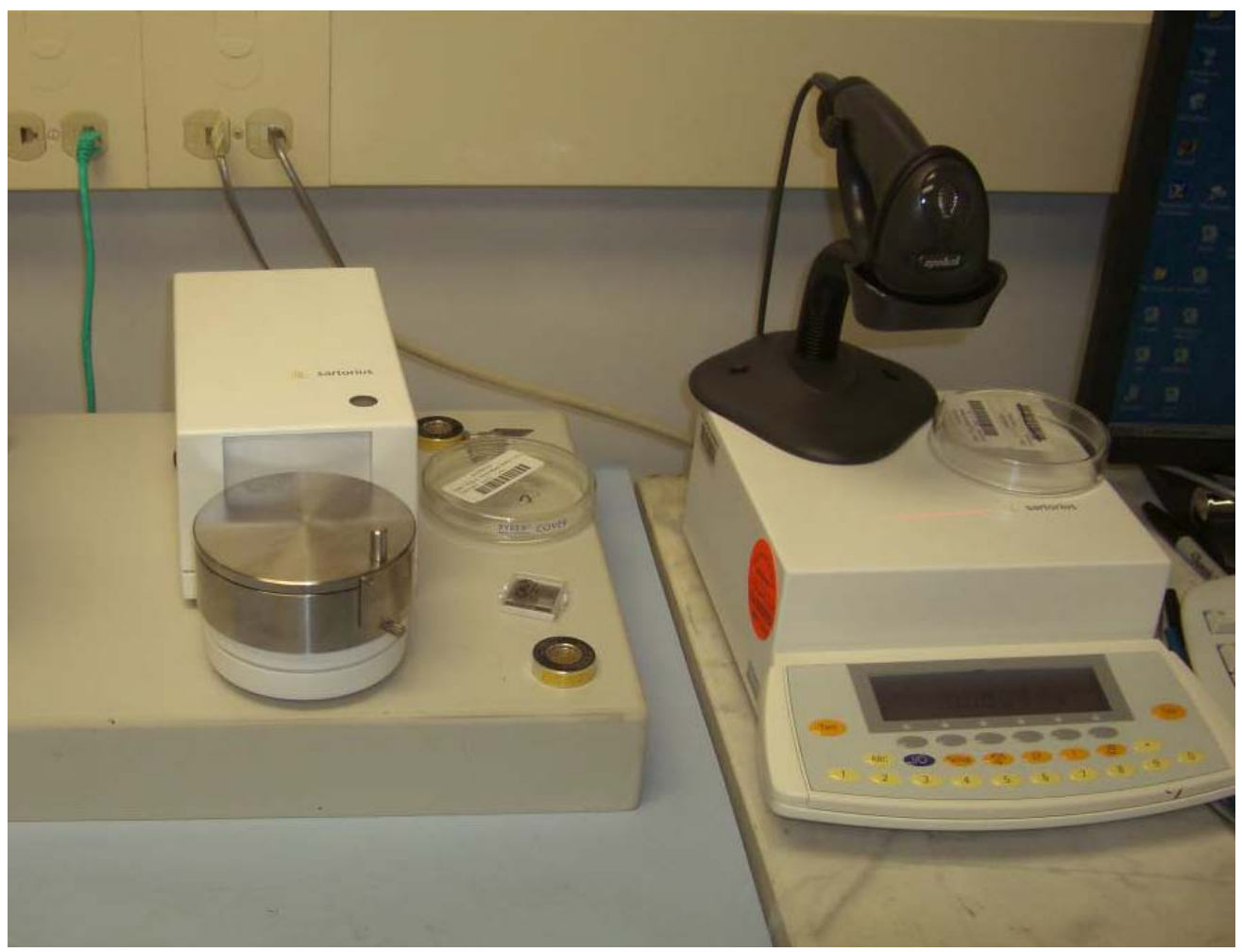

Figure 5 PM Filter Weighting Devices 


\subsection{Hydrogen Fuel System}

As shown in Figure 6, the $\mathrm{H}_{2}$ fuel system consisted of a high pressure $\mathrm{H}_{2}$ supply system, low pressure $\mathrm{H}_{2}$, fuel metering and delivery system, and safety system.

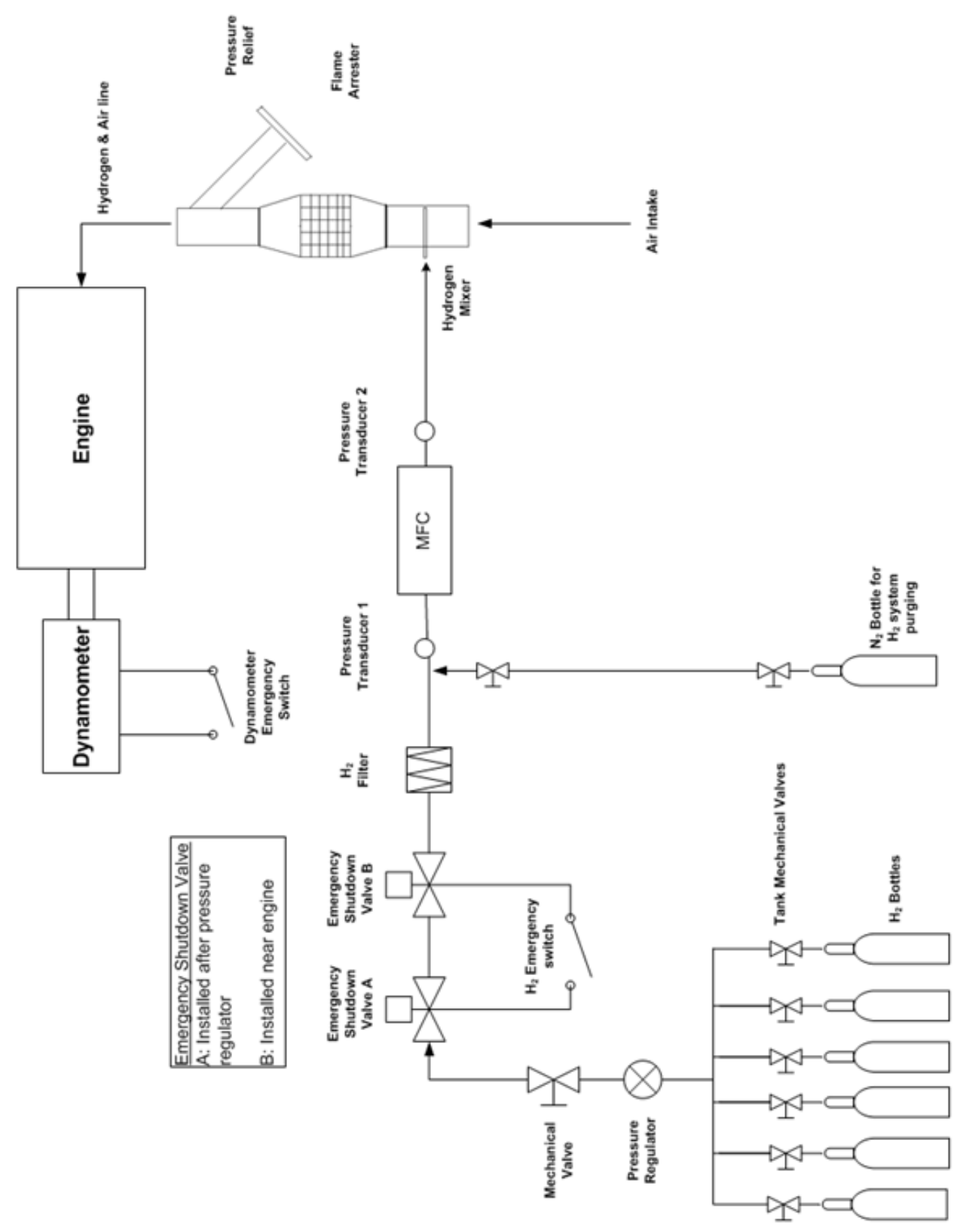

Figure 6 Schematic Diagram of $\mathrm{H}_{2}$ Fuel System 


\subsubsection{High Pressure $\mathrm{H}_{2}$ Fuel System}

The high pressure $\mathrm{H}_{2}$ fuel system was located outside the engine laboratory as shown in Figure 7. The module consisted of two sets of pressure regulators. Each regulator was connected to six $\mathrm{H}_{2}$ tanks with maximum pressure of 2000 psi and used to steadily provide $\mathrm{H}_{2}$ with gauge pressure of 45 psi. One emergency shut-down valve driven by the pneumatic actuator operated by compressed air was installed after the pressure regulator as shown in Figure 7.

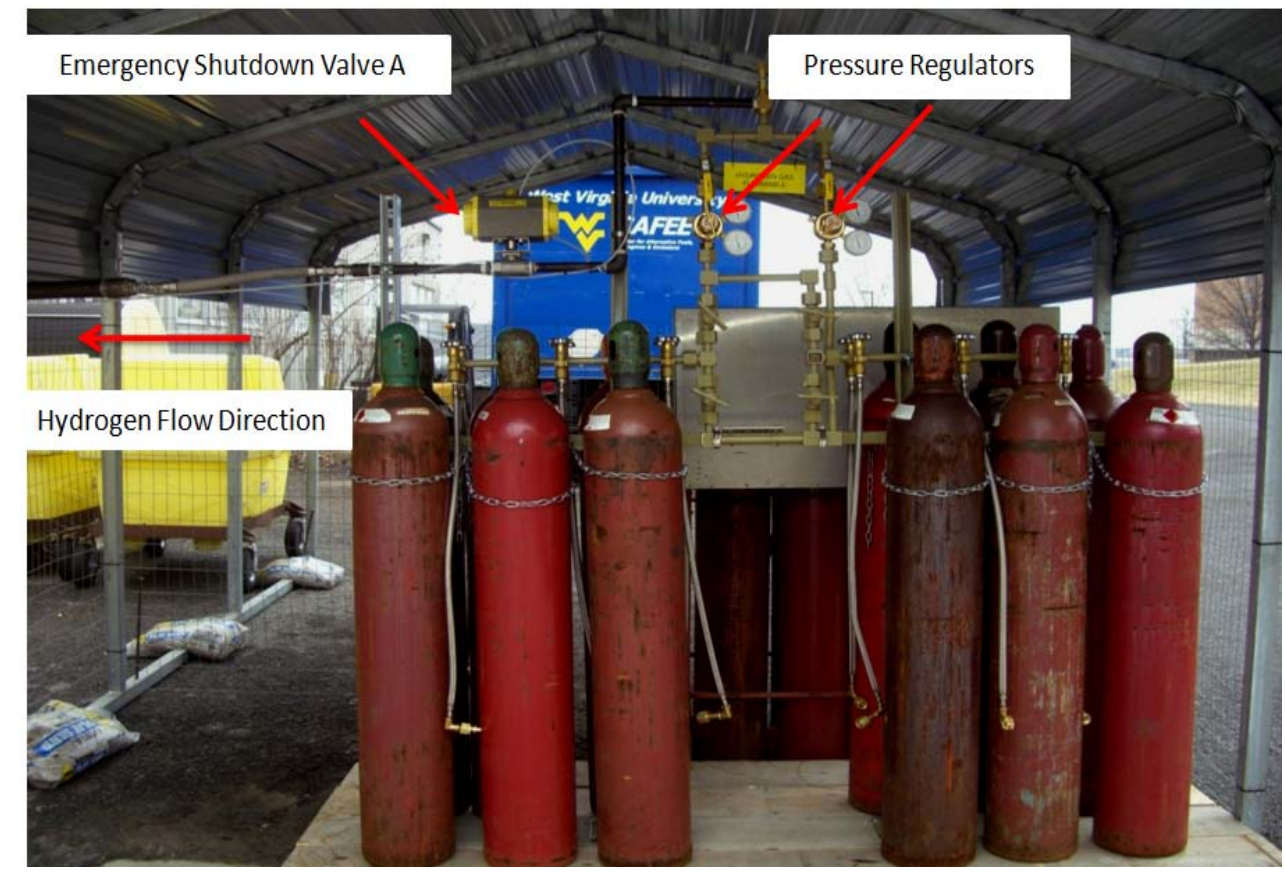

Figure 7 Hydrogen Station with Pressure Regulation Module and Emergency Valve A

\subsubsection{Low Pressure $\mathrm{H}_{2}$ Fuel System}

The low pressure $\mathrm{H}_{2}$ fuel system consisted of an emergency shut-down valve B, $\mathrm{H}_{2}$ filter, mass flow controller, and mixer as shown in Figure 8. The $\mathrm{H}_{2}$ filter was installed prior to all other devices in order to trap particulate. A second emergency shutdown valve B was located prior to the filter. Both emergency shut-down valves acted 
simultaneously to cut off $\mathrm{H}_{2}$ flow if the switch was activated. A mass flow controller was used to control and meter the flow rate of $\mathrm{H}_{2}$. An in-house made fuel mixer as shown in Figure 9 was installed about 0.5 feet prior to the flame arrester. The mixer was designed for delivering $\mathrm{H}_{2}$ into the main stream of the intake air.

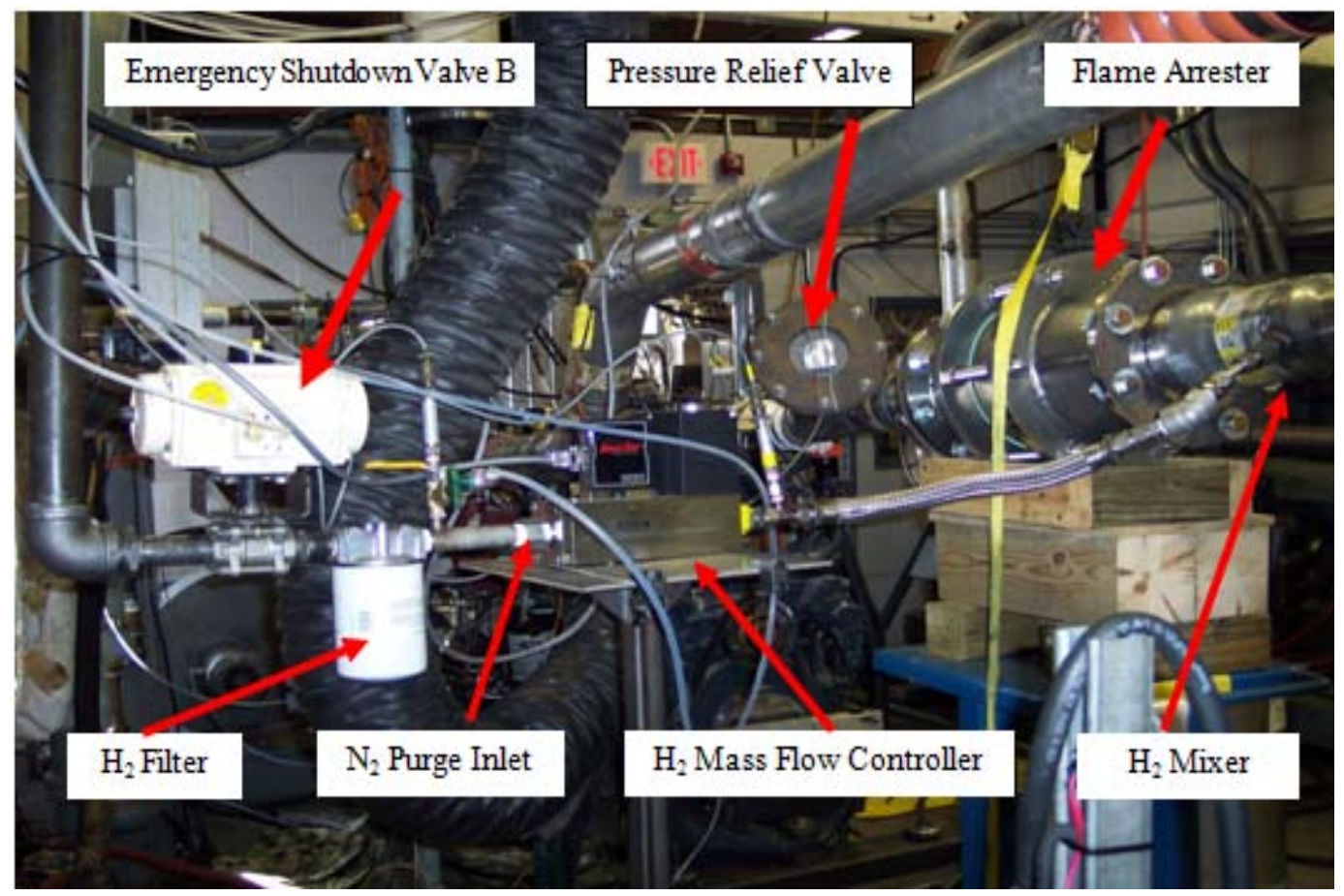

Figure 8 Hydrogen Fuel Metering and Control System with Safety Devices and Emergency Valve B

\subsubsection{Safety System and Safety Operation Procedure}

The safety system consisted of a stainless steel flame arrester, a pressure relief valve and the control system as shown in Figure 8. The flame arrester and pressure relief valve were installed prior to the engine intake manifold. The flame arrester was used to quench the flame propagation beyond the flame arrester and the pressure relief valve was acted to release the pressure established in the intake system in case of backfire. 


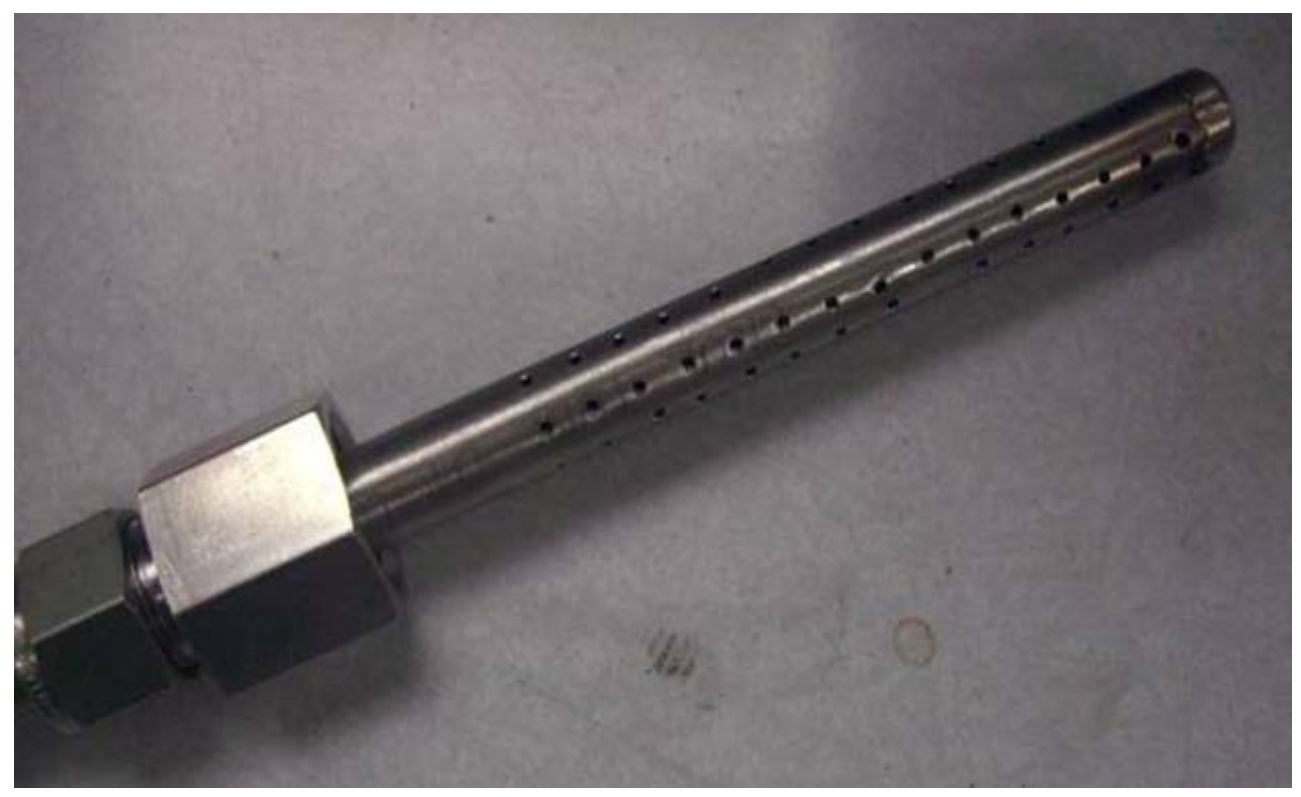

Figure 9 In-House $\mathrm{H}_{2}$ Mixer

Leakage check of the entire $\mathrm{H}_{2}$ fuel system using Snoop® product was conducted during the first day of testing and every week of the experimental period. In addition, verification of pressure drop along the $\mathrm{H}_{2}$ fuel system was conducted every day in order to ensure the system leakage free. Although leakage check was performed, but it may not guarantee leakage free. Therefore, the $\mathrm{H}_{2}$ fuel module was placed outside the research laboratory under a shed to avoid $\mathrm{H}_{2}$ accumulation. In the research laboratory, ventilation fans within the engine lab were turned on prior to, during, and at least 20 minutes after testing. The ventilation of the laboratory was maintained to avoid any $\mathrm{H}_{2}$ accumulation if an emergency or $\mathrm{H}_{2}$ system leak occurred.

Additional safety approaches were also implemented into the engine control system and the operation of $\mathrm{H}_{2}$ mass flow controller. The control system was designed to force the engine back to idle and shut down the mass flow controller if any of the following cases were detected: (1) the engine load was higher than the set value; (2) the flow of $\mathrm{H}_{2}$ was higher than the set value. 
A pressure transducer was installed prior to the mass flow controller and used as a reference signal for the opening and closing of the mass flow controller. The test cell control system was designed in such a way that it would not open the mass flow controller before the $\mathrm{H}_{2}$ pressure prior to the mass flow controller reached the set value and close the mass flow controller once the $\mathrm{H}_{2}$ pressure dropped below the set value. This prevented the over-opening of the mass flow controller in the event of a malfunction with the emergency valve.

\subsection{Flow Measurement of $\mathbf{H}_{2}$, Diesel, and Intake Air}

The diesel fuel flow rate was measured using a MAX 710 Fuel Measurement System manufactured by Max Machinery Inc. The intake air flow was measured using a laminar flow element (LFE) capable of measuring the flow of air from 0.2 to 957.12 scfm. The flow rate of $\mathrm{H}_{2}$ was controlled and measured using a compact-size digitally controlled mass flow controller manufactured by Sierra Instruments Inc. The small and large flow rate of $\mathrm{H}_{2}$ was controlled and measured using two compact-size, digitally controlled mass flow controllers. The small and large flow rate mass flow controller was capable of measuring and controlling from 0 to 10 standard liters per minute (slpm) and from 10 to 1200 slpm, respectively. In this research, the flow of $\mathrm{H}_{2}$ was controlled according to the air flow measured to obtain the pre-set $\mathrm{H}_{2}$ flow. The amount of $\mathrm{H}_{2}$ supplemented was reported as the volumetric concentration in the intake mixture noted as $\mathrm{H}_{2} /\left(\mathrm{H}_{2}+\right.$ air $)$. This made it easier to estimate the potential occurrence of backfire and engine knock and also to compare the emissions results obtained in different engines on the same basis. 


\subsection{In Cylinder Pressure Measurement}

The measurement of in-cylinder pressure was necessary to obtain the heat release rate. In this research, a piezoelectric pressure transducer was used to measure the dynamic cylinder pressure. The in-cylinder pressure for 1999 Cummins ISM370ESP engine and 2004 Mack MP7 355E engine were acquired at cylinder 6 and 1, respectively. The pressure transducer signal was converted to an amplified voltage through a charge amplifier, whereby this signal was sent to a high speed data acquisition system to record the in-cylinder pressure data in order to accommodate the in-cylinder pressure results. An incremental shaft encoder as shown in Figure 10 was installed to measure the crank angle.

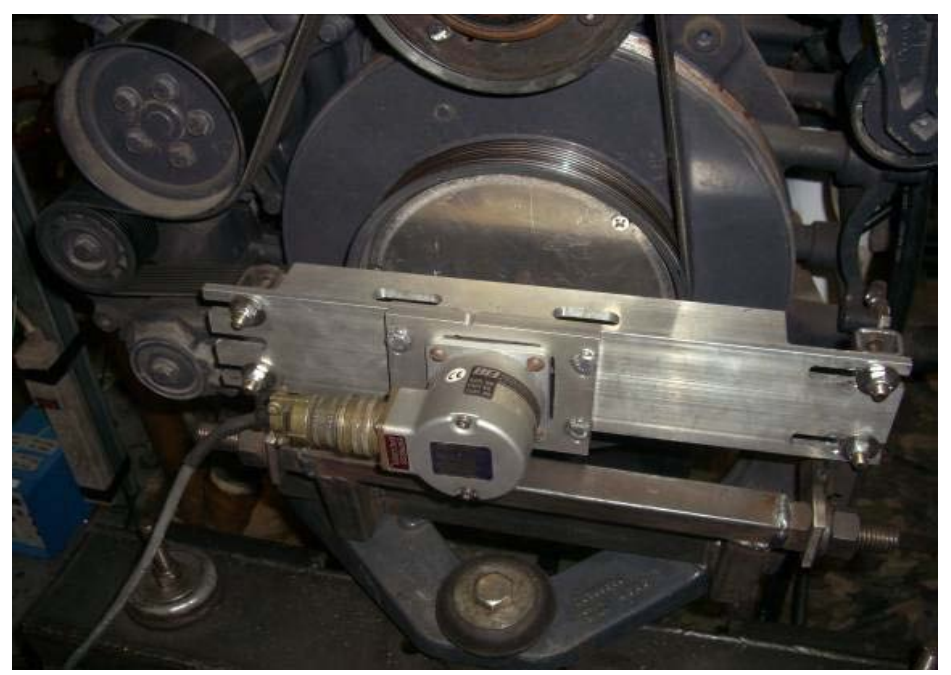

Figure 10 The Incremental Shaft Encoder

At the end of each emission sampling period, the cylinder pressure of 200 consecutive cycles were collected and averaged. A low-pass filter was applied to the measured in-cylinder pressure to minimize fluctuations caused by the pressure wave and reduce the high frequency combustion noise. The cut-off frequencies applied to the incylinder pressure of the 2004 Mack MP7 355E engine and 1999 Cummins ISM370ESP 
was $2000 \mathrm{~Hz}$ and $2500 \mathrm{~Hz}$, respectively. The filtered cylinder pressure was further processed to obtain the heat release process.

\subsection{Data Acquisition System}

During the experiment, the engine operation and performance data were acquired using the software and data acquisition hardware of WVU EERL. The engine testing data were collected using a signal conditioning backplane with Analog Devices 3B system modules and RTI-815 analog-to-digital converter data acquisition boards housed inside of the computer. The transducers and sensors needed were calibrated before initial testing. The engine data were first recorded in ADC code and then processed with an in-house software to convert them into engineering units. The setup of the instrumentation and data acquisition system is shown in Figure 11.

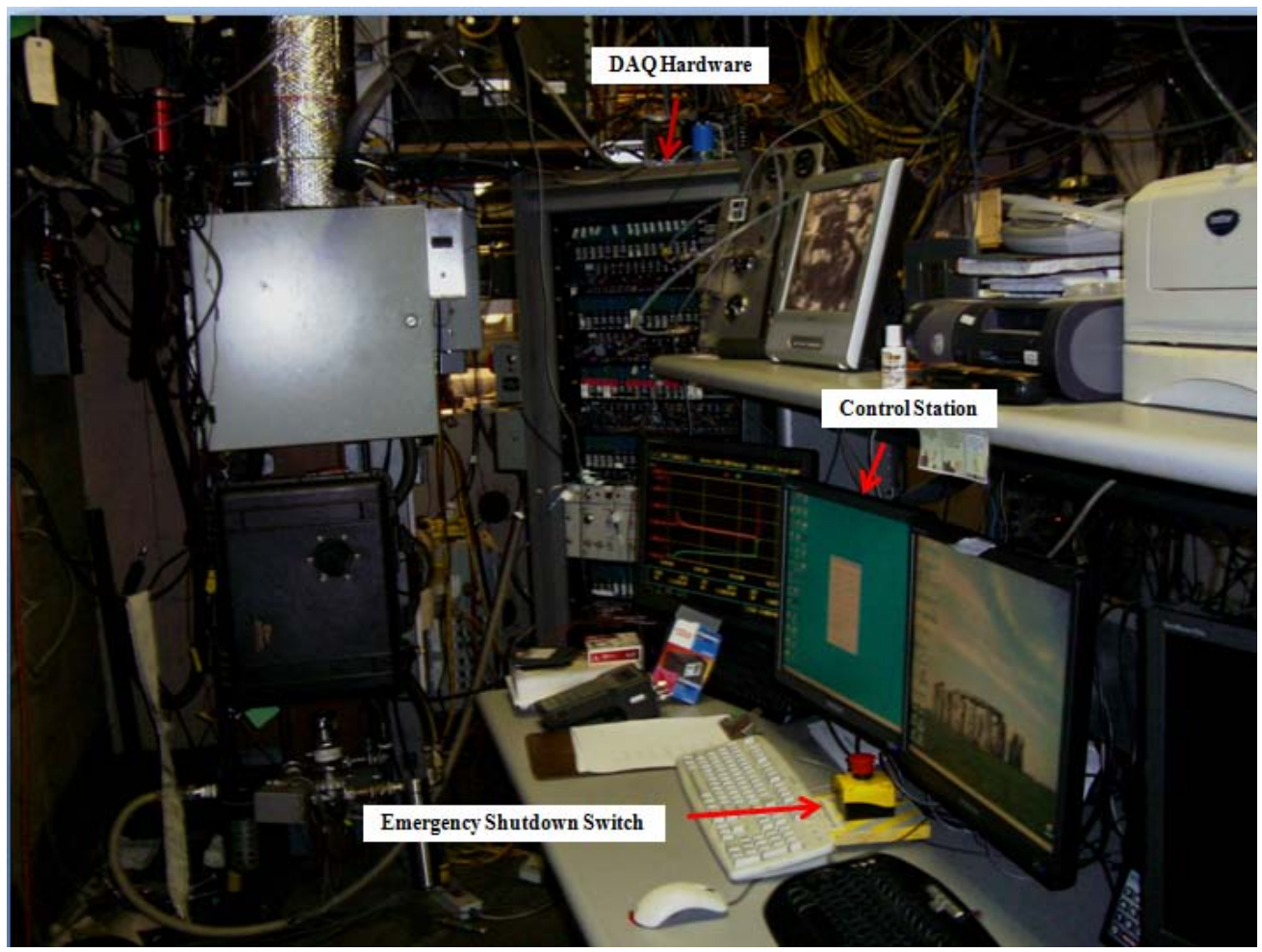

Figure 11 Instrumentation Control and Data Acquisition Bench 


\subsection{Engine Mapping}

Both engines were mapped prior to the initial test. Engine mapping procedures were followed in accordance to CFR 40, Part 86 Subpart N §86.1332-90 [CFR (4), 1998]. At least five maps were performed on each engine. Prior to the start of the mapping, the engine was warmed up at 3 minutes free idle, 7 minutes of 50\% peak torque speed and 10 minutes for rated speed and wide open throttle. Then, the engine was operated at wide open throttle and minimum engine speed. Engine speed was increased at an average rate of $8 \mathrm{RPM} / \mathrm{sec}( \pm 1 \mathrm{RPM} / \mathrm{sec})$ from minimum to maximum speed. The engine speed and torque points were recorded at $1 \mathrm{~Hz}$. The maximum torque for 2004 Mack MP7 355E and 1999 Cummins ISM370ESP at 1200 RPM was found to be 1399 and $1260 \mathrm{ft}-\mathrm{lb}$, respectively. As shown in Figure 12, the installation of $\mathrm{H}_{2}$ flame arrester has negligible effect on one of the engine map.

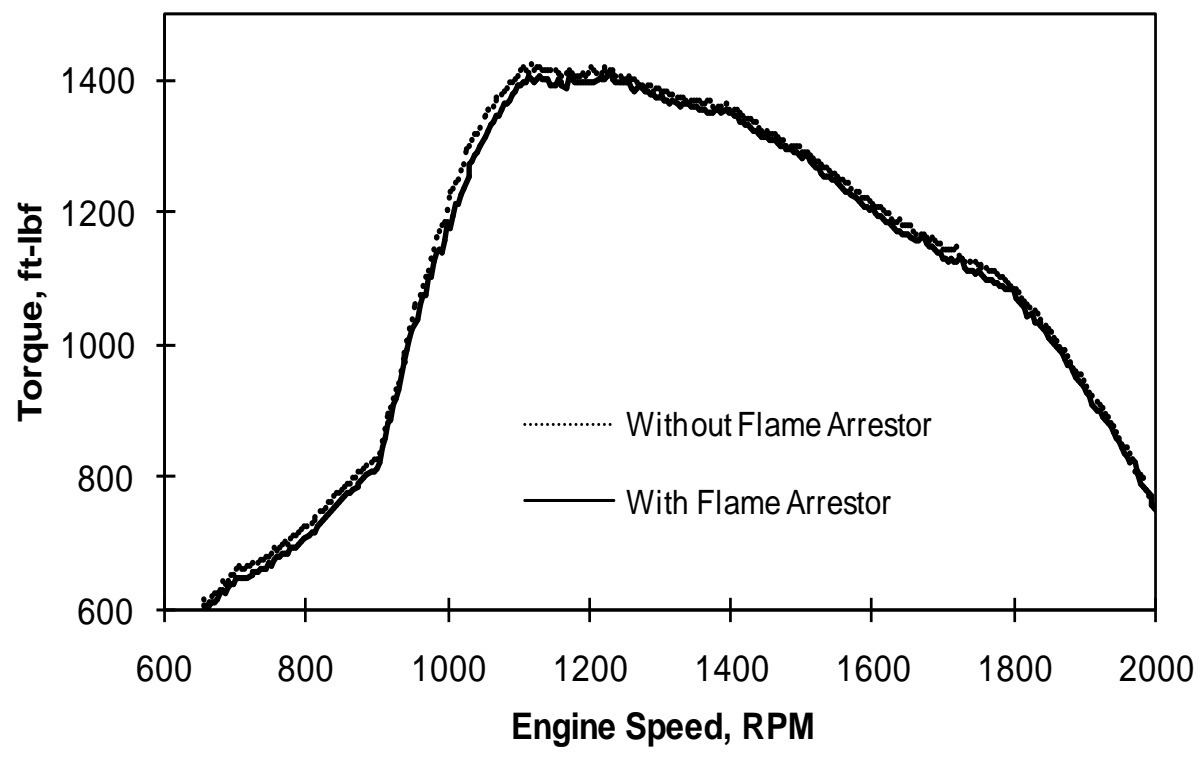

Figure 12 Effect of Flame Arrester on Engine Map of the 2004 Mack MP7 355E Engine 


\subsection{Uncertainty Analysis}

Experimental data are often used to supplement engineering analysis as a basis for design. Not all data are equally good, the validity of data should be documented before test results are used for design. Uncertainty analysis is the procedure used to quantify data validity and accuracy. Errors always are present when experimental measurements are made. There are two typical types of errors, the fixed error and random error. Fixed error is the same for each reading that can be removed by proper calibration or correction. However, random error is different for every reading and hence cannot be removed. The factors that introduce random error are uncertain by nature. The objective of uncertainty analysis is to estimate the probable random error in an experimental result.

In this research project, the validity of the experimental data is crucial when presenting the result. As shown in Figure 13, the calculated BTE with respect to the $\mathrm{H}_{2} /\left(\mathrm{H}_{2}+\right.$ Air) flow, involved with instrument's error such as LFE, fuel flow meter, and mass flow controller. Disregarding these probable errors in the BTE and $\mathrm{H}_{2} /\left(\mathrm{H}_{2}+\mathrm{Air}\right)$ flow calculation will deteriorate the validity of the experimental results. Therefore, the objective of this section is to determine the acceptable range for the experimental data by implementing the uncertainty analysis.

The calculation for the brake thermal efficiency and $\mathrm{H}_{2} /\left(\mathrm{H}_{2}+\right.$ Air $)$ flow involved with many parameters including intake air flow, diesel fuel flow, dynamometer speed and torque. Each parameter associate with an error percentage that provided from manufacturer's specification sheet as shown in Table 5. These range of errors will be integrate into the uncertainty analysis for calculation. The uncertainty analysis of BTE and $\mathrm{H}_{2} /\left(\mathrm{H}_{2}+\right.$ Air) flow for 2004 MACK MP7 355E at 30\% load with the addition of 6\% 
$\mathrm{H}_{2}$ was performed. The BTE accounted with LFE, mass flow controller, and fuel meter as the error parameter. The $\mathrm{H}_{2} /\left(\mathrm{H}_{2}+\right.$ Air) flow accounted LFE and mass flow controller as the error parameter. Due to the complexity of the equation, a MATLAB program as shown in the appendix was developed to perform the uncertainty analysis. The uncertainty results for the BTE and $\mathrm{H}_{2} /\left(\mathrm{H}_{2}+\right.$ Air) flow for 2004 MACK MP7 355E at 30\% ( $6 \% \mathrm{H}_{2}$ ) were $38.8 \% \pm 0.36 \%$ and $5.84 \% \pm 0.102 \%$, respectively.

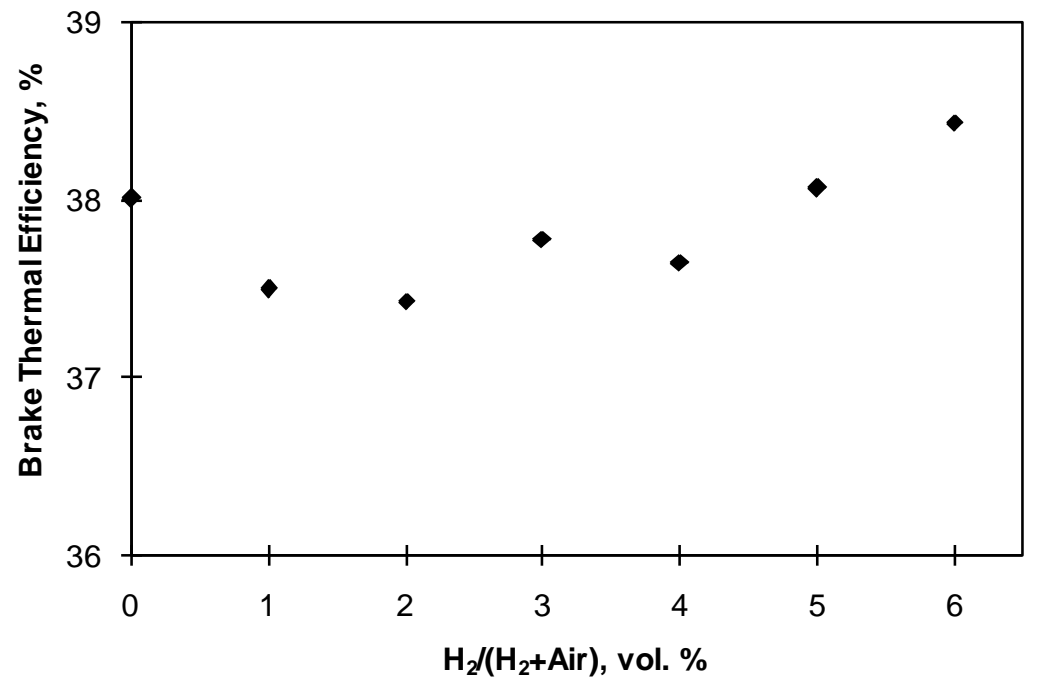

Figure 13 Effect of $\mathrm{H}_{2}$ Addition and Engine Load on BTE for 2004 Mack MP7 355E, $\mathrm{N}=1200 \mathrm{RPM}, 30 \%$ Load

Table 5 Percentage Error of Measurement Instruments [Sierra Instrument, 2008; Meriam, 2010; Max Machinery, 2004]

\begin{tabular}{|c|c|c|}
\hline Manufacturer & Instrument & Error (Full scale at operating condition) \\
\hline Sierra Instrument & Mass flow controller & $1 \%$ \\
\hline Meriam & Laminar flow element & $0.86 \%$ \\
\hline Max Machinery & Fuel meter & $0.50 \%$ \\
\hline
\end{tabular}




\section{INVESTIGATION OF EMISSIONS AND COMBUSTION OF A 1999 CUMMINS ISM370ESP ENGINE SUPPLEMENTED WITH $\mathrm{H}_{2}$}

\subsection{Test Matrix}

The test matrix was designed to investigate the effect of $\mathrm{H}_{2}$ addition, engine load, and engine speed on the engine performance, exhaust emissions, and combustion process of diesel engine operation. The effect of $\mathrm{H}_{2}$ addition on the exhaust emissions was also measured using 13-mode ESC. The mode was set according to the ESC standard as shown in Figure 14 and Table 6. The effect of the addition of 2 and $4 \% \mathrm{H}_{2}$ on the exhaust emissions was investigated using 13-mode ESC.

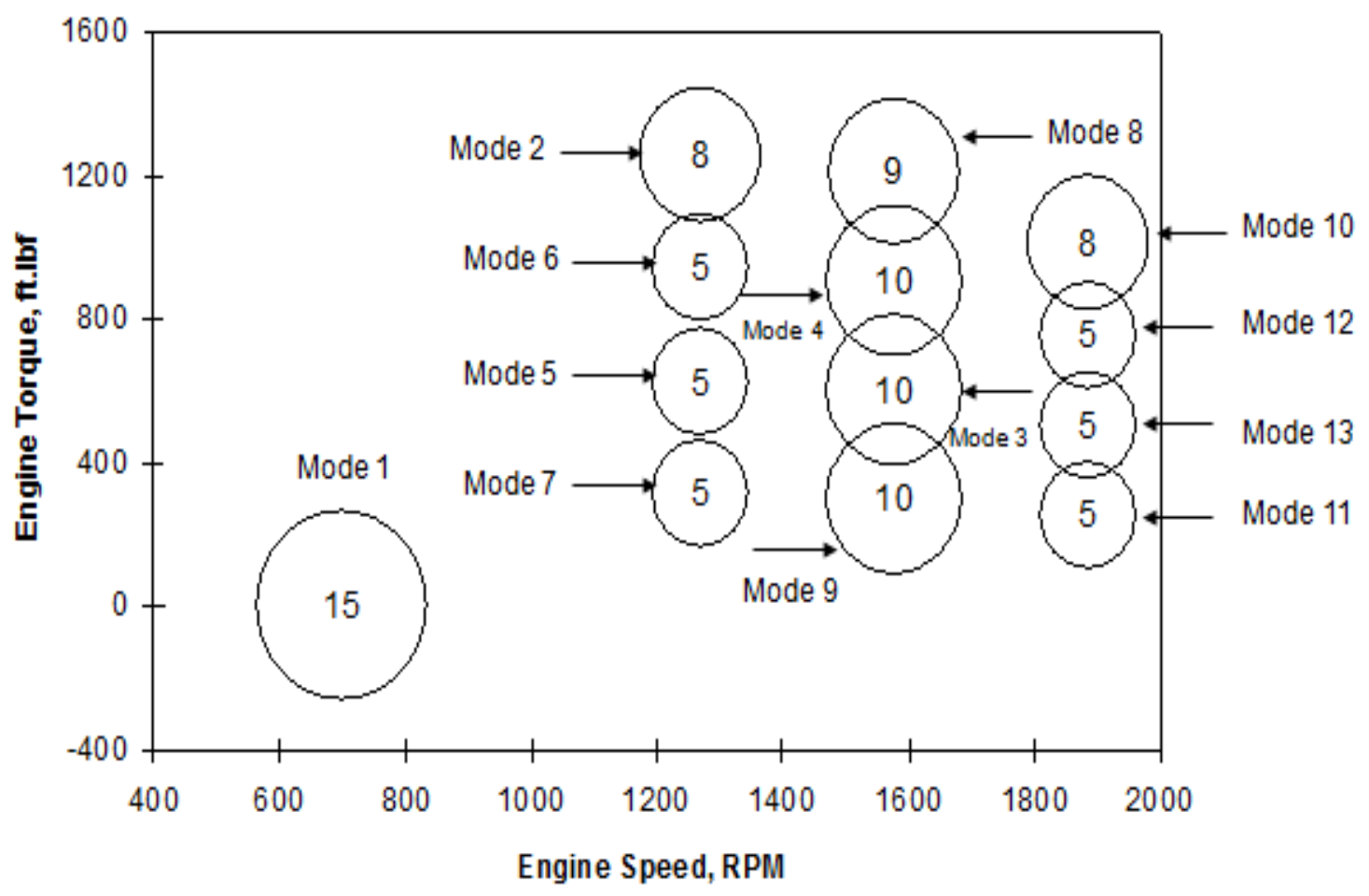

Figure 14 Set Points for 13-Mode ESC Emission Testing 
Table 6 Set Points for 13-Mode ESC, 1999 Cummins ISM370ESP

\begin{tabular}{|c|c|c|c|}
\hline Mode & $\begin{array}{c}\text { Speed, } \\
\text { RPM }\end{array}$ & Torque, ft-lb & Weighting Factor, \% \\
\hline 1 & 700 & 0 & 15 \\
\hline 2 & 1272 & 1258 & 8 \\
\hline 3 & 1580 & 606 & 10 \\
\hline 4 & 1580 & 908 & 10 \\
\hline 5 & 1272 & 629 & 5 \\
\hline 6 & 1272 & 944 & 5 \\
\hline 7 & 1272 & 315 & 5 \\
\hline 8 & 1580 & 1211 & 10 \\
\hline 9 & 1580 & 303 & 8 \\
\hline 10 & 1887 & 1011 & 5 \\
\hline 11 & 1887 & 253 & 5 \\
\hline 12 & 1887 & 758 & 5 \\
\hline 13 & 1887 & 506 & 9 \\
\hline
\end{tabular}

The detailed effect of $\mathrm{H}_{2}$ addition on the combustion and exhaust emissions was investigated under constant load varied from 10 to $70 \%$ with addition of up to $6.5 \% \mathrm{H}_{2}$ into intake air. The complete constant load test matrix for 1999 Cummins ISM370ESP was described in Table 7. Figure 15 shows the effect of $\mathrm{H}_{2}$ addition on equivalent ratio. The equivalent ratio of $\mathrm{H}_{2}$ increased linearly from 0 to 0.17 , with the addition of $\mathrm{H}_{2}$ from 1 to $6.5 \%$, respectively. 
Table 7 Constant Load Test Matrix for 1999 Cummins ISM370ESP, N=1200 RPM

\begin{tabular}{|c|c|}
\hline Torque, $\%$ & $\mathbf{H}_{2} /\left(\mathbf{H}_{2}+\right.$ Air $)$, vol. $\%$ \\
\hline 10 & $0.0,1.0,2.0,3.0,3.5,4.0,4.5,5.0,5.5$, and 6.0 \\
\hline 15 & $0.0,0.2,0.4,0.6,0.8,1.0,2.0,3.0,3.5,4.0,4.5,5.0,5.5,6.0$, and 6.5 \\
\hline 20 & $0.0,1.0,2.0,3.0,3.5,4.0,4.5,5.0,5.5,6.0$, and 6.5 \\
\hline 30 & $0.0,0.2,0.4,0.6,0.8,1.0,2.0,3.0,3.5,4.0,4.5,5.0,5.5,6.0$, and 6.5 \\
\hline 50 & $0.0,1.0,2.0,3.0,3.5,4.0,4.5,5.0,5.5,6.0$, and 6.5 \\
\hline 70 & $0.0,0.2,0.4,0.6,0.8,1.0,2.0,2.5,3.0,3.5,4.0,4.5,5.0$, and 6.0 \\
\hline
\end{tabular}

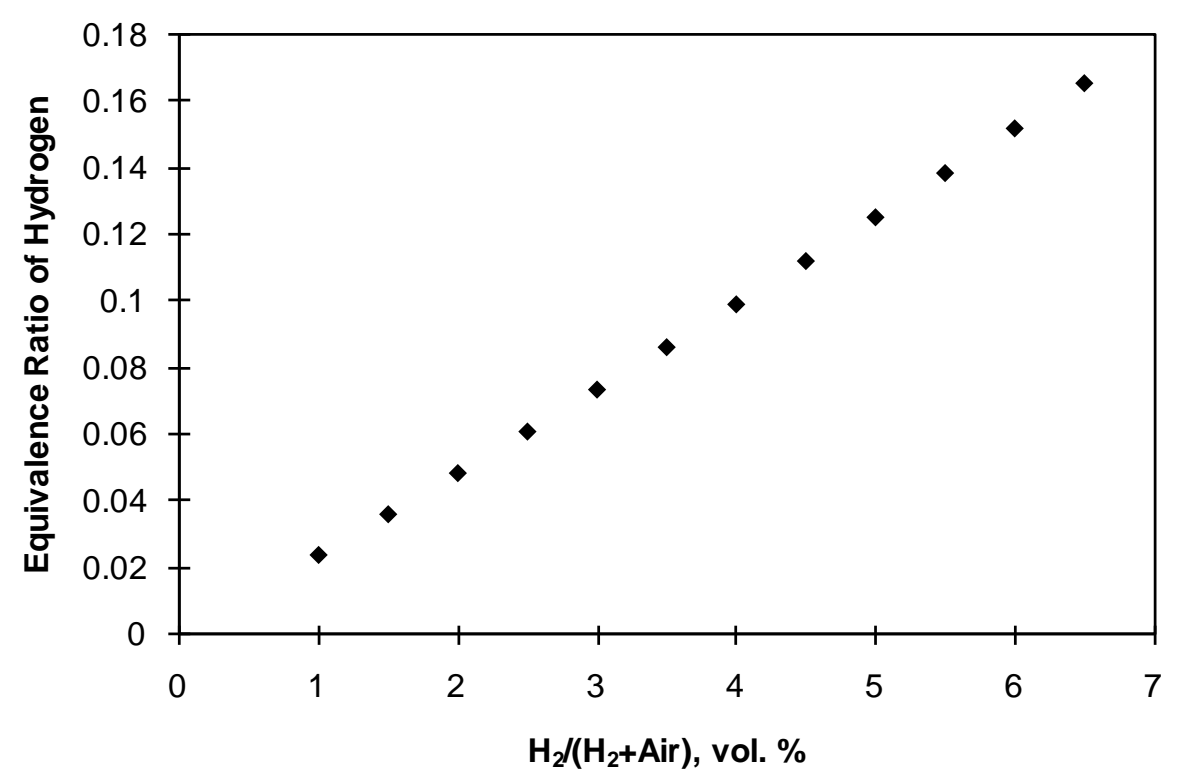

Figure 15 Effect of $\mathrm{H}_{2}$ Addition on $\mathrm{H}_{2}$ Equivalence Ratio, 1999 Cummins ISM370ESP

Table 8 shows the variation of $\mathrm{H}_{2}$ flow rate and diesel substitution with the change in engine load at $6 \% \mathrm{H}_{2}$ addition into the intake mixture. Figure 16 shows the variation of the substitution of diesel by $\mathrm{H}_{2}$ with the changes in engine load and the 
addition of $\mathrm{H}_{2}$. The addition of $6 \% \mathrm{H}_{2}$ contributed to $92.1 \%$ of the intake energy including $\mathrm{H}_{2}$ and diesel fuel.

Table 8 Hydrogen Flow Rate at $\mathrm{H}_{2} /\left(\mathrm{H}_{2}+\mathrm{Air}\right)=$ vol. $6 \%$ for 1999 Cummins ISM370ESP

\begin{tabular}{|c|c|c|c|}
\hline \multicolumn{4}{|c|}{$\mathbf{H}_{2}$ Flow at $\mathbf{H}_{2} /\left(\mathbf{H}_{2}+\right.$ Air $)=$ vol. 6\% } \\
\hline Load, \% & Kg/hr & L/min & $\begin{array}{c}\text { Diesel } \\
\text { Substitution, \% }\end{array}$ \\
\hline 10 & 2.10 & 391.07 & 92.1 \\
\hline 15 & 2.08 & 387.52 & 77.4 \\
\hline 20 & 2.10 & 391.44 & 64.5 \\
\hline 30 & 2.30 & 430.08 & 49.3 \\
\hline 50 & 2.78 & 518.37 & 37.3 \\
\hline 70 & 3.30 & 615.25 & 31.7 \\
\hline
\end{tabular}

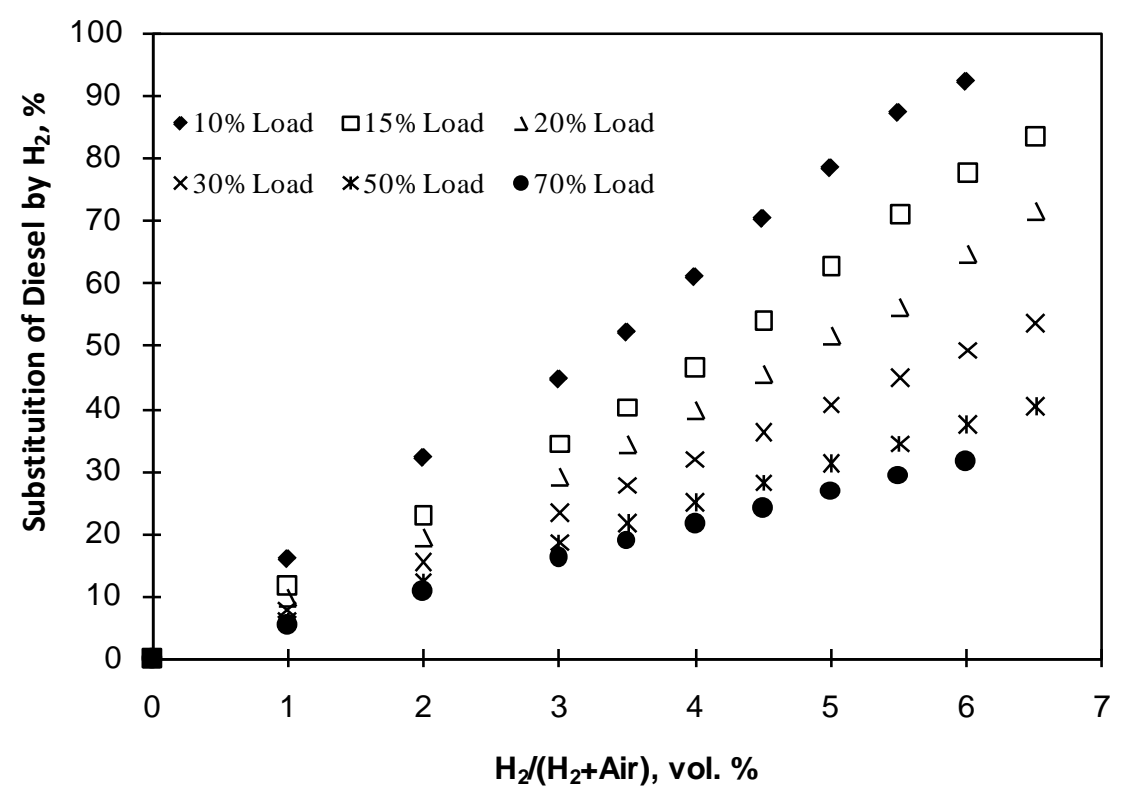

Figure 16 Effect of $\mathrm{H}_{2}$ Addition on Diesel Substitution, 1999 Cummins ISM370ESP, $\mathrm{N}=1200$ RPM, 10-70\% Load

Figure 17 shows the effect of $\mathrm{H}_{2}$ addition on the equivalent ratio of diesel fuel. The equivalent ratio on every load decreased linearly with the addition of $\mathrm{H}_{2}$ up to 6.5\%. 
The addition of $\mathrm{H}_{2}$ reduced the equivalence ratio of diesel fuel due to the reduced diesel flow rate. The lowest equivalent ratio of 0.015 was observed at $10 \%$ load with $6 \% \mathrm{H}_{2}$ addition. The total equivalent ratio of $\mathrm{H}_{2}$ and diesel fuel was calculated with respect to the addition of $\mathrm{H}_{2}$ as shown in Figure 18. The effect of $\mathrm{H}_{2}$ addition on total equivalent ratio was small.

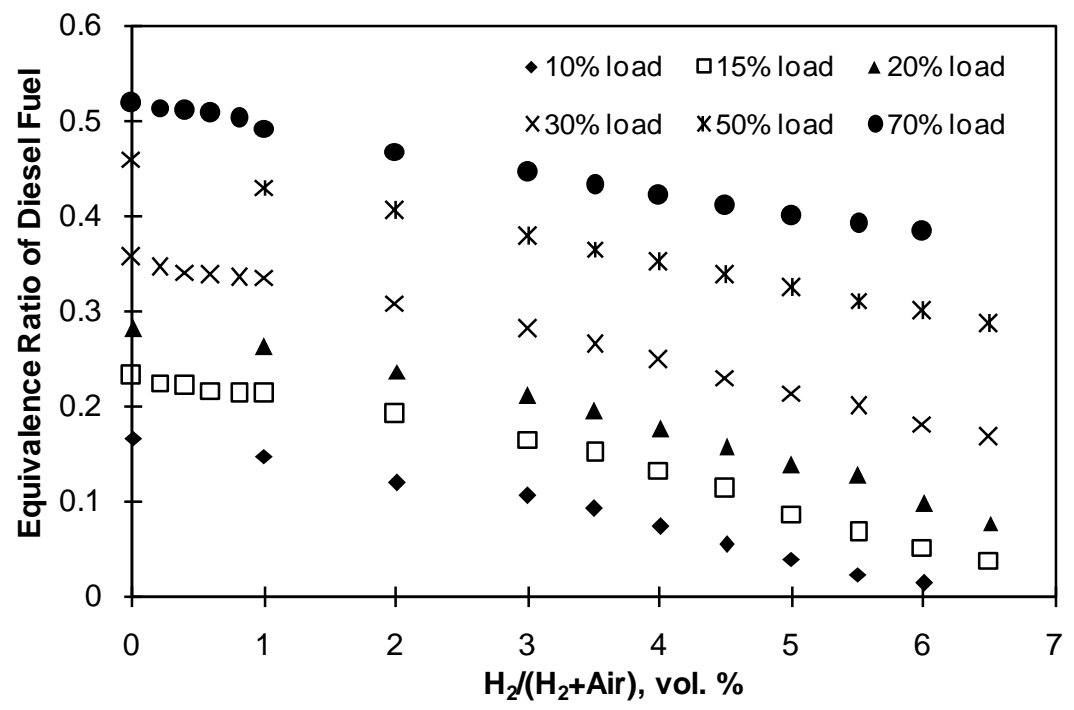

Figure 17 Effect of $\mathrm{H}_{2}$ Addition on Diesel Fuel Equivalence Ratio, 1999 Cummins ISM370ESP, N=1200 RPM, 10-70\% Load

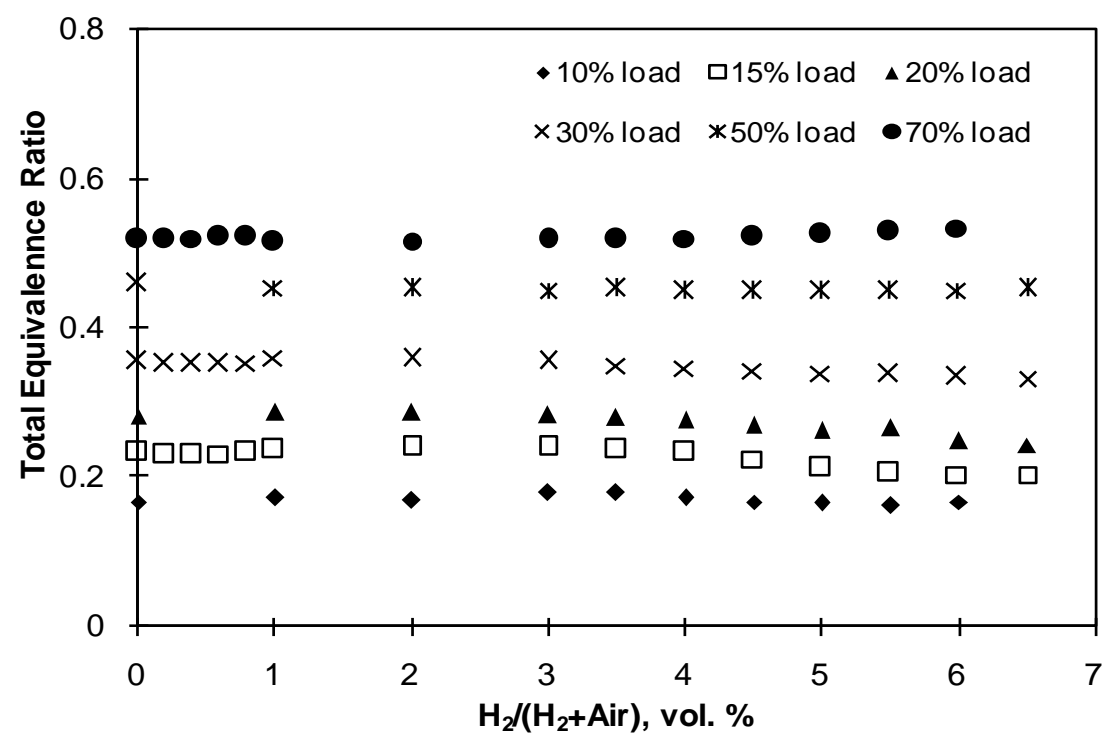

Figure 18 Effect of $\mathrm{H}_{2}$ Addition on Total Equivalence Ratio, 1999 Cummins ISM370ESP, N=1200 RPM, 10-70\% Load 
The operating conditions under constant diesel fuel flow rate at 1200 RPM were shown in Table 9. The engine load was varied by adjusting the amount of $\mathrm{H}_{2}$ supplemented into the diesel engine. When running this test for 1999 Cummins ISM370ESP, the flow rate of diesel fuel was kept approximately at a constant 22.35 $\mathrm{kg} / \mathrm{hr}$, corresponding to $50 \%$ load for pure diesel operation. The maximum $\mathrm{H}_{2}$ supplemented was 5.5\%.

Table 9 Test Matrix for Constant Diesel Fuel Flow Rate, 1999 Cummins ISM370ESP

\begin{tabular}{|c|c|}
\hline Diesel Flow Rate, $\mathbf{k g} / \mathbf{h r}$ & $\mathbf{H}_{\mathbf{2}} /\left(\mathbf{H}_{2}+\right.$ Air $)$, vol. \% \\
\hline 22.35 & $0.0,1.0,2.0,3.0,4.0,4.5,5.0$, and 5.5 \\
\hline
\end{tabular}

As shown in Table 10, the effect of engine speed and $\mathrm{H}_{2}$ addition was examined under constant torque of $700 \mathrm{ft}-\mathrm{lb}$ with the addition of $4 \% \mathrm{H}_{2}$ in the intake mixture and engine speed ranging from 1200 to 1800 RPM.

Table 10 Test Matrix for Constant Torque with Variable Engine Speed, 1999 Cummins ISM370ESP

\begin{tabular}{|c|c|c|}
\hline $\begin{array}{c}\text { Engine } \\
\text { Torque (ft-lb) }\end{array}$ & $\mathbf{H}_{2} /\left(\mathbf{H}_{2}+\right.$ Air $)$, vol. $\%$ & Engine Speed, RPM \\
\hline 700 & 4 & $1200,1300,1400,1500,1600,1700$, and 1800 \\
\hline
\end{tabular}

\subsection{Repeatability of Exhaust Emissions and Fuel Consumption Measurement}

The engine test used in this research was able to obtain good repeatability of exhaust emissions [Tincher, 2007] and fuel consumption. In this research, the repeatability of this engine test cell was examined by measuring the exhaust emissions of a 1999 Cummins ISM370ESP diesel engine using 13-mode ESC. As shown in Table 11, 
the emissions of $\mathrm{NO}_{\mathrm{x}}, \mathrm{NO}, \mathrm{PM}, \mathrm{CO}, \mathrm{HC}$ and $\mathrm{CO}_{2}$ were shown to have good repeatability for four tests. The coefficient of variation (COV) for $\mathrm{NO}_{\mathrm{x}}, \mathrm{NO}, \mathrm{PM}, \mathrm{CO}, \mathrm{HC}$ and $\mathrm{CO}_{2}$ emissions were $0.30,0.27,7.70,0,4.16$, and $0.06 \%$, respectively.

Table 11 Repeatability of $\mathrm{NO}_{\mathrm{x}}$ Exhaust Emissions Measured Using 13-Mode ESC, g/bhp$\mathrm{hr}$

\begin{tabular}{|c|c|c|c|c|c|c|}
\hline Emissions (g/bhp-hr) & $\mathrm{NO}_{\mathrm{x}}$ & $\mathrm{NO}$ & $\mathrm{PM}$ & $\mathrm{CO}$ & $\mathrm{HC}$ & $\mathrm{CO}_{2}$ \\
\hline Test 1 & 3.50 & 3.38 & 0.025 & 0.22 & 0.12 & 473.8 \\
\hline Test 2 & 3.49 & 3.36 & 0.028 & 0.22 & 0.12 & 473.6 \\
\hline Test 3 & 3.49 & 3.37 & 0.027 & 0.22 & 0.13 & 473.4 \\
\hline Test 4 & 3.48 & 3.36 & 0.024 & 0.22 & 0.12 & 473.0 \\
\hline Average & 3.49 & 3.37 & 0.026 & 0.22 & 0.12 & 473.5 \\
\hline Std Deviation & 0.01 & 0.01 & 0.002 & 0.00 & 0.005 & 0.3 \\
\hline COV, \% & 0.30 & 0.27 & 7.70 & 0.00 & 4.16 & 0.06 \\
\hline
\end{tabular}

As shown in Table 12, the COV of $\mathrm{NO}_{\mathrm{x}}$ emissions measured for each mode was within $1.03 \%$. The $\mathrm{NO}_{\mathrm{x}}$ emissions of each mode are shown in Figure 19. The accuracy of engine test cell was also examined by comparing the diesel fuel consumption measured using diesel fuel flow meter and the carbon balance method. As shown in Table 13, the maximum difference of diesel fuel flow rate measured using these two approaches were $2.8 \%$.

Table 12 Repeatability of $\mathrm{NO}_{\mathrm{x}}$ Exhaust Emissions of Each Mode Measured Using 13Mode ESC, g/bhp-hr

\begin{tabular}{|c|c|c|c|c|c|c|c|c|c|c|c|c|}
\hline Mode & 2 & 3 & 4 & 5 & 6 & 7 & 8 & 9 & 10 & 11 & 12 & 13 \\
\hline Test 1 & 2.86 & 3.13 & 3.65 & 3.73 & 3.57 & 4.09 & 3.33 & 4.16 & 3.44 & 4.30 & 3.66 & 4.03 \\
\hline Test 2 & 2.83 & 3.10 & 3.64 & 3.74 & 3.58 & 4.07 & 3.33 & 4.19 & 3.44 & 4.31 & 3.63 & 4.02 \\
\hline Test 3 & 2.79 & 3.09 & 3.64 & 3.78 & 3.57 & 4.10 & 3.30 & 4.19 & 3.43 & 4.32 & 3.65 & 4.00 \\
\hline Test 4 & 2.80 & 3.09 & 3.63 & 3.74 & 3.54 & 4.06 & 3.30 & 4.19 & 3.44 & 4.26 & 3.62 & 4.00 \\
\hline Average & 2.82 & 3.10 & 3.64 & 3.75 & 3.56 & 4.08 & 3.31 & 4.18 & 3.44 & 4.30 & 3.64 & 4.01 \\
\hline Std Dev & 0.03 & 0.02 & 0.01 & 0.02 & 0.02 & 0.02 & 0.02 & 0.01 & 0.00 & 0.02 & 0.02 & 0.01 \\
\hline COV, \% & 1.03 & 0.64 & 0.27 & 0.63 & 0.47 & 0.42 & 0.47 & 0.36 & 0.00 & 0.56 & 0.44 & 0.33 \\
\hline
\end{tabular}




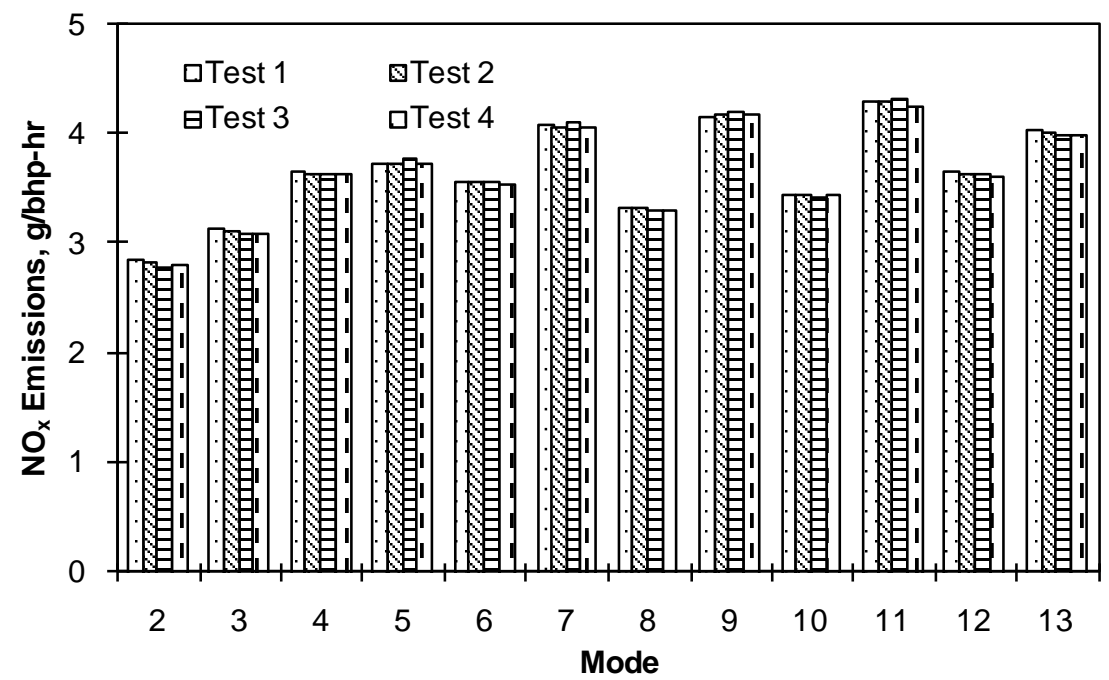

Figure 19 Repeatability of $\mathrm{NO}_{\mathrm{x}}$ Emissions of Each Mode Measured During 13-Mode ESC, g/bhp-hr

Table 13 Comparison of Diesel Flow Rate Measured Using 13-Mode ESC

\begin{tabular}{|c|c|c|c|c|c|c|c|c|c|c|c|c|}
\hline Mode & 2 & 3 & 4 & 5 & 6 & 7 & 8 & 9 & 10 & 11 & 12 & 13 \\
\hline $\begin{array}{c}\text { Diesel Flow } \\
\text { Meter (kg/hr) }\end{array}$ & 45.97 & 27.76 & 39.91 & 23.08 & 33.71 & 12.44 & 53.50 & 15.51 & 54.02 & 16.71 & 41.16 & 28.58 \\
\hline $\begin{array}{c}\text { Carbon } \\
\text { Balance } \\
\text { (kg/hr) }\end{array}$ & 45.78 & 28.46 & 39.95 & 23.21 & 33.72 & 12.68 & 53.04 & 15.77 & 53.60 & 17.17 & 41.23 & 28.78 \\
\hline \begin{tabular}{c} 
Difference, \% \\
\hline
\end{tabular} & 0.41 & -2.49 & -0.09 & -0.59 & -0.04 & -1.98 & 0.86 & -1.68 & 0.79 & -2.80 & -0.17 & -0.71 \\
\hline
\end{tabular}

\subsection{3-Mode ESC}

In this research, the effect of $\mathrm{H}_{2}$ addition $\left(\mathrm{H}_{2} /\left(\mathrm{H}_{2}+\mathrm{Air}\right)\right.$, vol=2 and 4\%) on regulated emissions was measured using 13-mode ESC. As shown in Table 14 the addition of $2 \% \mathrm{H}_{2}$ increased PM emissions from 0.032 to $0.037 \mathrm{~g} / \mathrm{bhp}-\mathrm{hr}(+15.6 \%)$. In comparison, the addition of $4 \% \mathrm{H}_{2}$ reduced the PM emissions to $0.029 \mathrm{~g} / \mathrm{bhp}-\mathrm{hr}(-9.4 \%)$. 
Table 14 Effect of $\mathrm{H}_{2}$ Addition on Exhaust Emissions Measured Using 13-Mode ESC, g/bhp-hr

\begin{tabular}{|c|c|c|c|c|c|}
\hline $\mathbf{H}_{2} /\left(\mathbf{H}_{\mathbf{2}}+\right.$ Air), vol. $\%$ & $\mathbf{P M}$ & $\mathbf{N O}_{\mathbf{x}}$ & $\mathbf{C O}$ & $\mathbf{H C}$ & $\mathbf{C O}_{\mathbf{2}}$ \\
\hline 0 & 0.032 & 3.41 & 0.25 & 0.12 & 474.7 \\
\hline 2 & 0.037 & 3.59 & 0.26 & 0.12 & 416.7 \\
\hline 4 & 0.029 & 3.94 & 0.21 & 0.13 & 347.9 \\
\hline
\end{tabular}

As shown in Table 14, the addition of 2 and $4 \% \mathrm{H}_{2}$ increased the emissions of $\mathrm{NO}_{\mathrm{x}}$ from 3.41 to 3.59 (+5.28\%) and $3.94 \mathrm{~g} / \mathrm{bhp}-\mathrm{hr}(+15.5 \%)$, respectively. The effect of $\mathrm{H}_{2}$ addition on $\mathrm{NO}_{\mathrm{x}}$ emissions measured in each mode is shown in Figure 20. The addition of 2 and $4 \%$ of $\mathrm{H}_{2}$ increased the $\mathrm{NO}_{\mathrm{x}}$ emissions in all modes with the exception of mode 9 (1578 RPM, $306 \mathrm{ft}-\mathrm{lb}$ ) and 11 (1886 RPM and $254 \mathrm{ft}-\mathrm{lb})$, representing the low load operation. This may reflect to the different response of $\mathrm{NO}_{\mathrm{x}}$ emissions with the addition of $\mathrm{H}_{2}$ under high and low load operation.

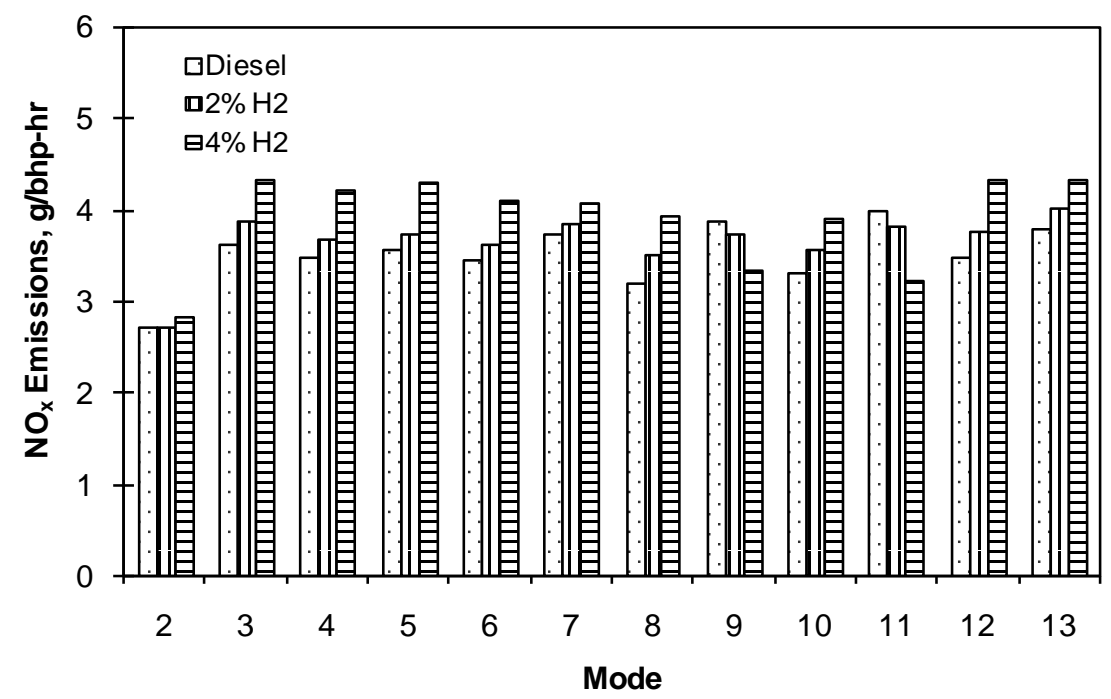

Figure 20 Effect of $\mathrm{H}_{2}$ Addition on $\mathrm{NO}_{\mathrm{x}}$ Emissions, 13-Mode ESC 
As shown Table 14, the addition of $2 \% \mathrm{H}_{2}$ slightly increased the $\mathrm{CO}$ emissions from 0.25 to $0.26 \mathrm{~g} / \mathrm{bhp}-\mathrm{hr}(+4.0 \%)$ compared to pure diesel operation. However, the addition of $4 \% \mathrm{H}_{2}$ reduced $\mathrm{CO}$ emissions from 0.25 to $0.21 \mathrm{~g} / \mathrm{bhp}-\mathrm{hr}$ (-16.0\%). The detailed effect of $\mathrm{H}_{2}$ addition on $\mathrm{CO}$ emissions measured at each mode is shown in Figure 21. The addition of $2 \% \mathrm{H}_{2}$ increased the emissions of $\mathrm{CO}$ at mode $2,4,5,6$, and 8 . The addition of $4 \% \mathrm{H}_{2}$ reduced the emissions of $\mathrm{CO}$ at all modes with exception on mode 2 .

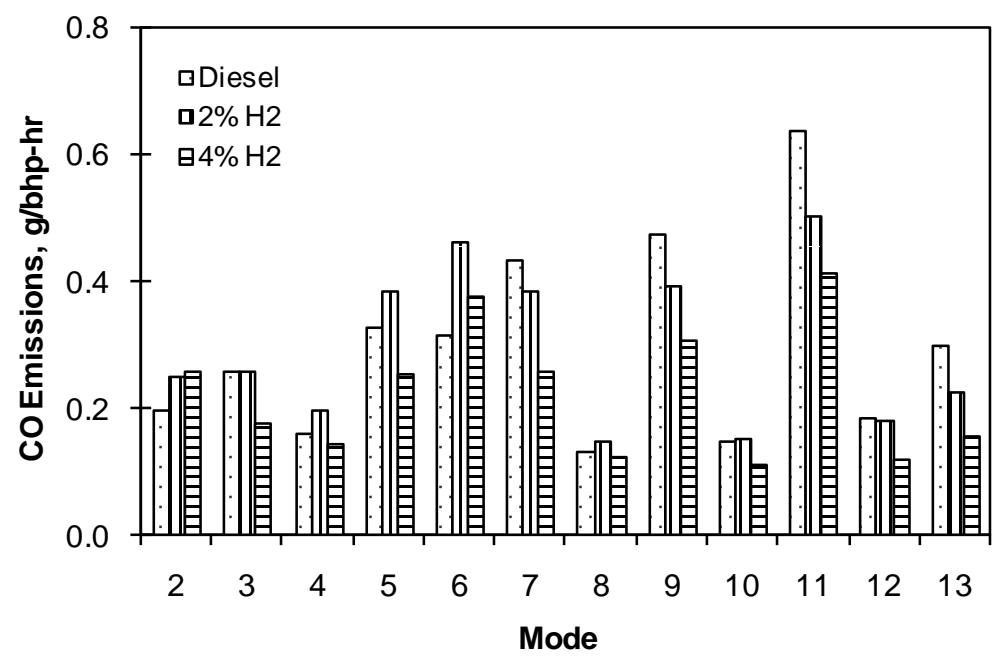

Figure 21 Effect of $\mathrm{H}_{2}$ Addition on CO Emission, 13-Mode ESC

As shown in Table 14, the addition of $2 \% \mathrm{H}_{2}$ had negligible effect on the emission of HC. In comparison, the addition of $4 \% \mathrm{H}_{2}$ slightly increased the emissions of $\mathrm{HC}$ from 0.12 to $0.13 \mathrm{~g} / \mathrm{bhp}-\mathrm{hr}(+8.3 \%)$. As shown in Figure 22, the addition of $4 \% \mathrm{H}_{2}$ increased the $\mathrm{HC}$ emissions for all of the emissions modes. However, the addition of $2 \% \mathrm{H}_{2}$ slightly increased the HC emissions with the exception of mode 2, 4, 6, 7, and 8. 


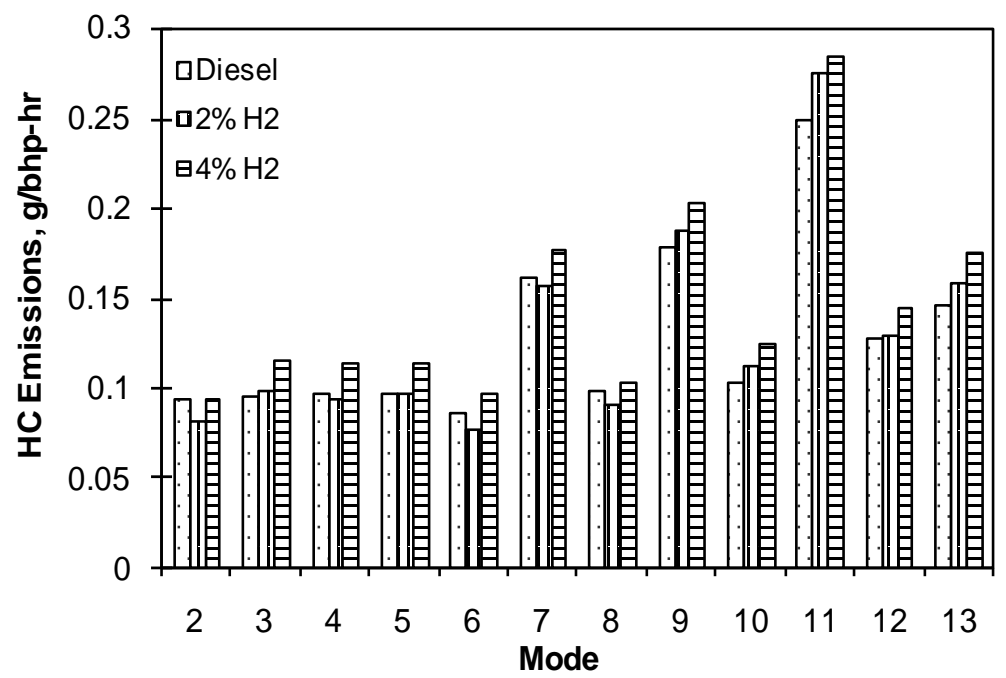

Figure 22 Effect of $\mathrm{H}_{2}$ Addition on HC Emissions, 13-Mode ESC

As shown in Table 14, the addition of 2 and $4 \% \mathrm{H}_{2}$ reduced $\mathrm{CO}_{2}$ emissions from 474.7 to $416.7(-12.2 \%)$ and $347.9 \mathrm{~g} / \mathrm{bhp}-\mathrm{hr}(-26.7 \%)$, respectively. The detailed effect of $\mathrm{H}_{2}$ addition on $\mathrm{CO}_{2}$ emissions can be found in Figure 23. The addition of 2 and $4 \% \mathrm{H}_{2}$ reduced the $\mathrm{CO}_{2}$ emissions measured at each mode.

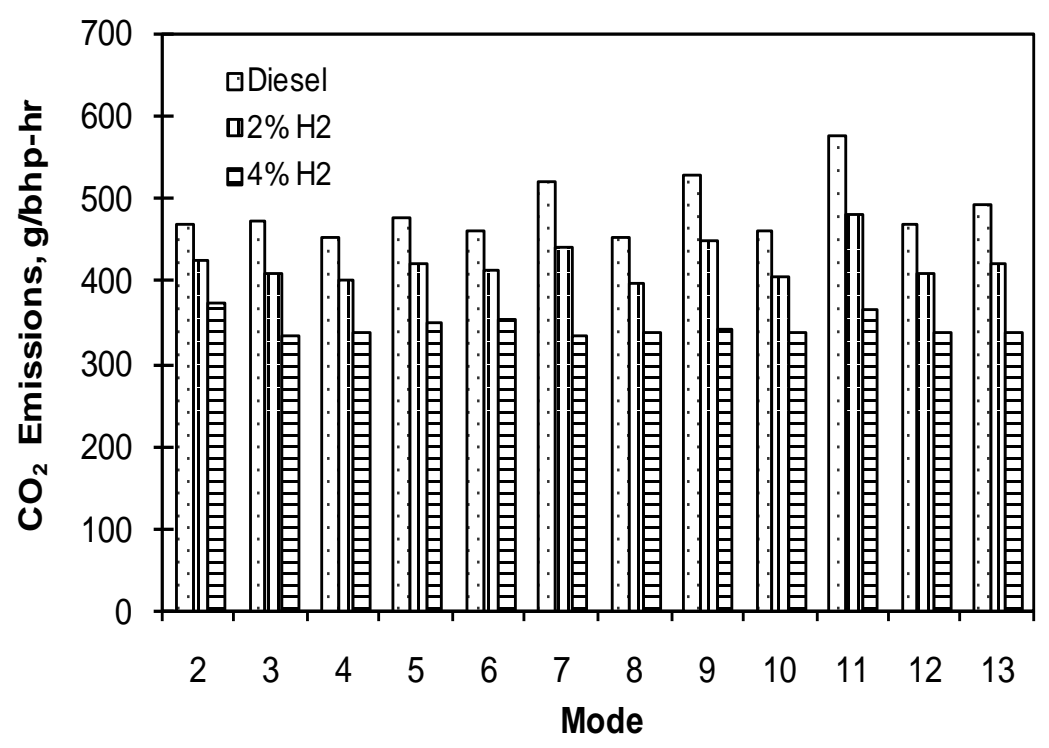

Figure 23 Effect of $\mathrm{H}_{2}$ Addition on $\mathrm{CO}_{2}$ Emissions, 13-Mode ESC 


\subsection{Effect of $\mathrm{H}_{2}$ Addition and Engine Load on Exhaust Emissions 4.4.1 Effect of $\mathrm{H}_{2}$ Addition on the Emissions of $\mathrm{NO}_{\mathrm{x}}$, $\mathrm{NO}$, and $\mathrm{NO}_{2}$}

The effect of $\mathrm{H}_{2}$ addition on $\mathrm{NO}_{\mathrm{x}}$ emissions was examined under constant load operation. As shown in Figure 24 for medium to high load operation, the addition of $\mathrm{H}_{2}$ into the intake mixture of this 1999 Cummins ISM370ESP diesel engine increased gradually the $\mathrm{NO}_{\mathrm{x}}$ emissions, which was consistent with the data reported in the literature [McWilliam et al., 2008; and Varde and Frame, 1983]. This was due to the increased combustion temperature when $\mathrm{H}_{2}$ was added. As shown in Figure 25 for $70 \%$ load operation, the addition of a small amount of $\mathrm{H}_{2}$ into the diesel engine slightly reduced the maximum averaged bulk mixture temperature without reducing the $\mathrm{NO}_{\mathrm{x}}$ emissions. The addition of a relatively large amount of $\mathrm{H}_{2}$ increased substantially the maximum averaged bulk mixture temperature, which was accompanied by the increased $\mathrm{NO}_{\mathrm{x}}$ emissions. As shown in Figure 26, the addition of $\mathrm{H}_{2}$ also enhanced the conversion of $\mathrm{NO}$ to $\mathrm{NO}_{2}$.

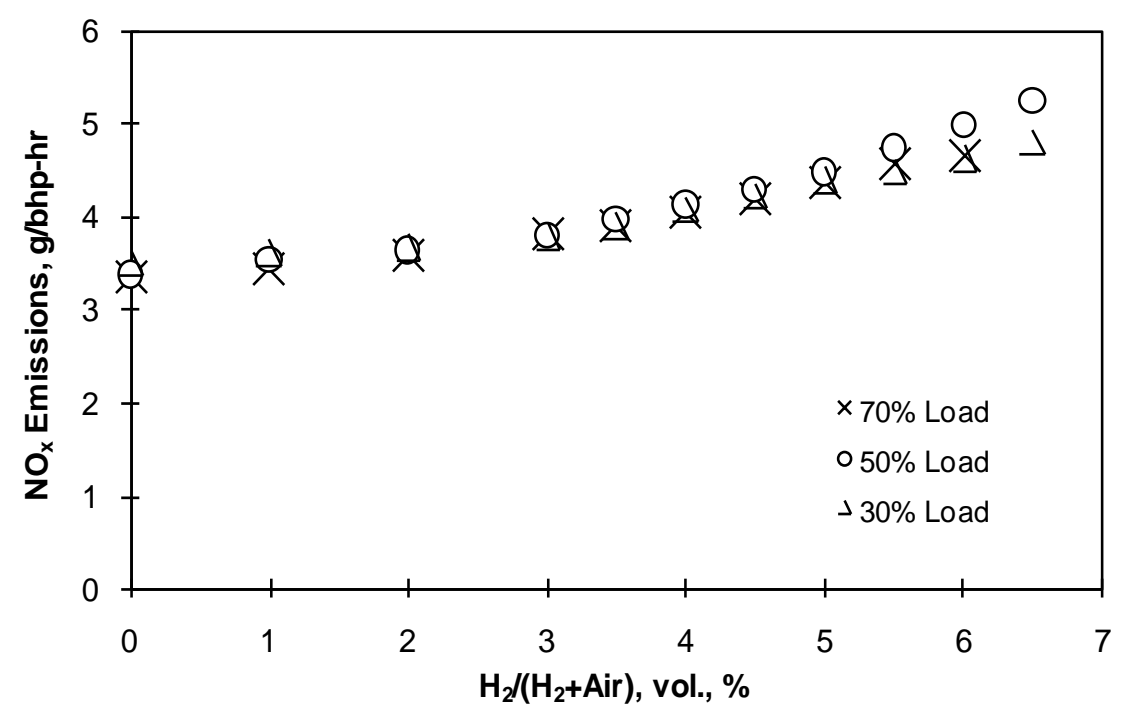

Figure 24 Effect of $\mathrm{H}_{2}$ Addition on $\mathrm{NO}_{\mathrm{x}}$ Emissions, N=1200 RPM, 30-70\% Load 


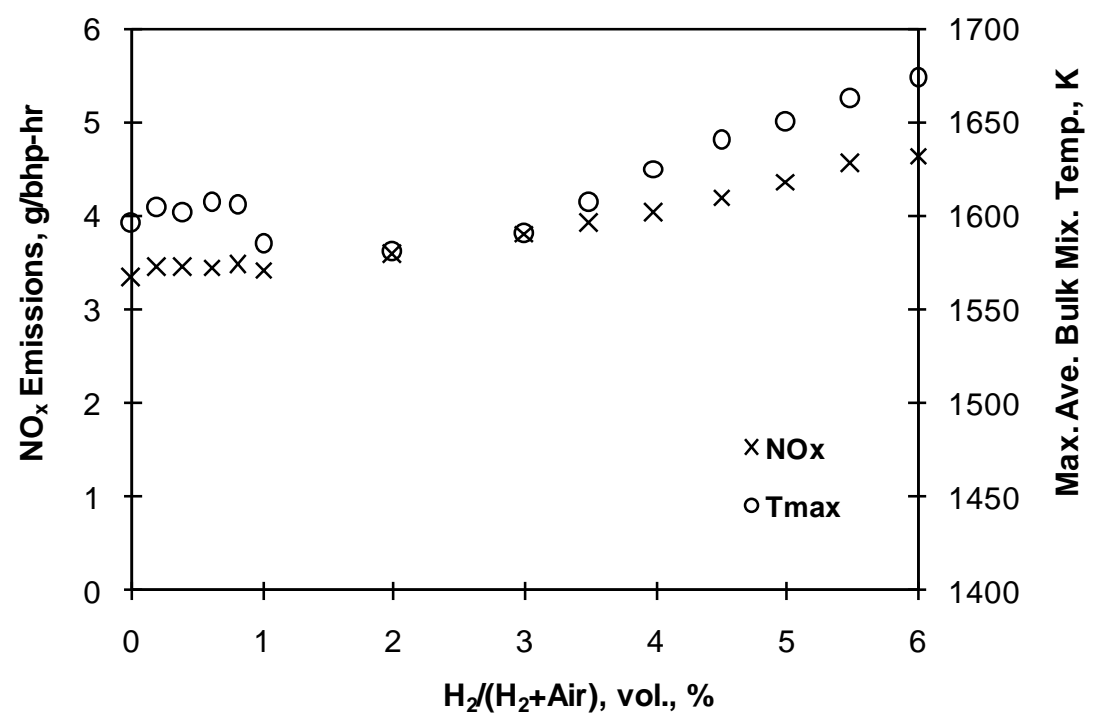

Figure 25 Effect of $\mathrm{H}_{2}$ Addition on $\mathrm{NO}_{\mathrm{x}}$ Emissions and Maximum Average Bulk Mixture Temperature Calculated Using Cylinder Pressure, N=1200 RPM, 70\% Load

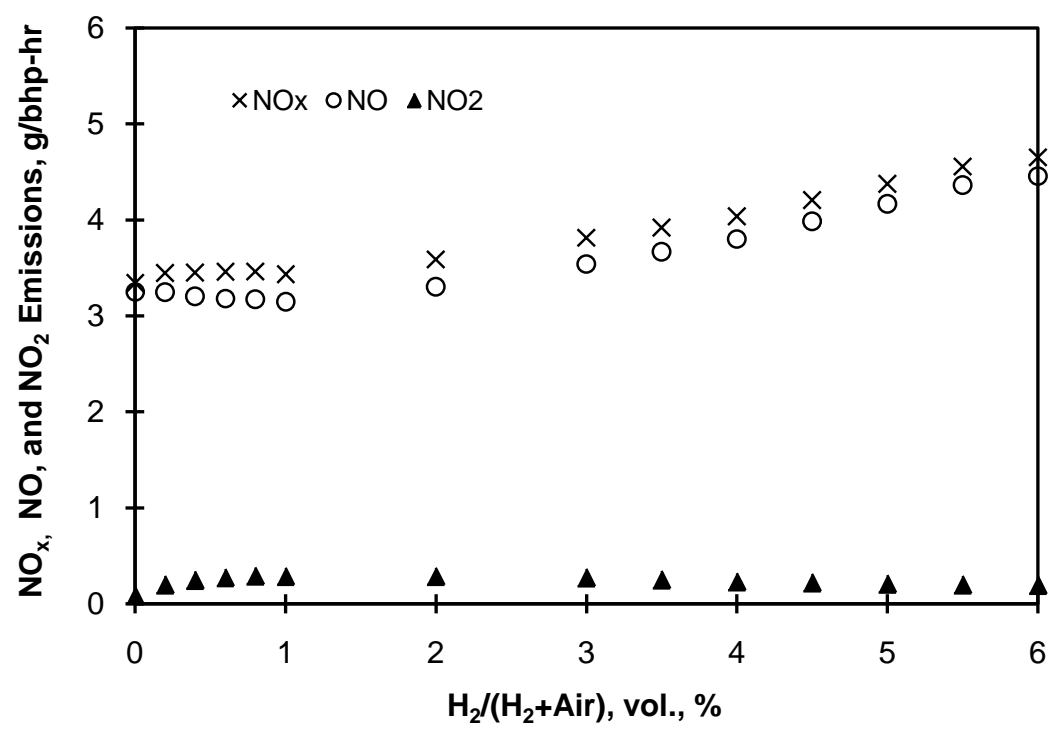

Figure 26 Effect of $\mathrm{H}_{2}$ Addition on the Emissions of $\mathrm{NO}_{x}, \mathrm{NO}$, and $\mathrm{NO}_{2}, \mathrm{~N}=1200 \mathrm{RPM}$, $70 \%$ Load

The effect of $\mathrm{H}_{2}$ addition on $\mathrm{NO}_{\mathrm{x}}$ emissions was also examined under low load operation. As shown in Figure 27, the addition of a small amount of $\mathrm{H}_{2}(<3 \%)$ at $10 \%$ load had a negligible effect on $\mathrm{NO}_{\mathrm{x}}$ emissions. Increasing the addition of $\mathrm{H}_{2}$ beyond $3 \%$ substantially reduced the emissions of $\mathrm{NO}_{\mathrm{x}}$. In comparison, the addition of $\mathrm{H}_{2}$ at 15 and 
$20 \%$ load slightly increased the emissions of $\mathrm{NO}_{\mathrm{x}}$ until a maximum value was observed. Further increasing the addition of $\mathrm{H}_{2}$ started to reduce the emissions of $\mathrm{NO}_{\mathrm{x}}$. The substantial reduction of $\mathrm{NO}_{\mathrm{x}}$ emissions was only obtained at a very narrow low load operational range with the addition of a relatively large amount of $\mathrm{H}_{2}$.

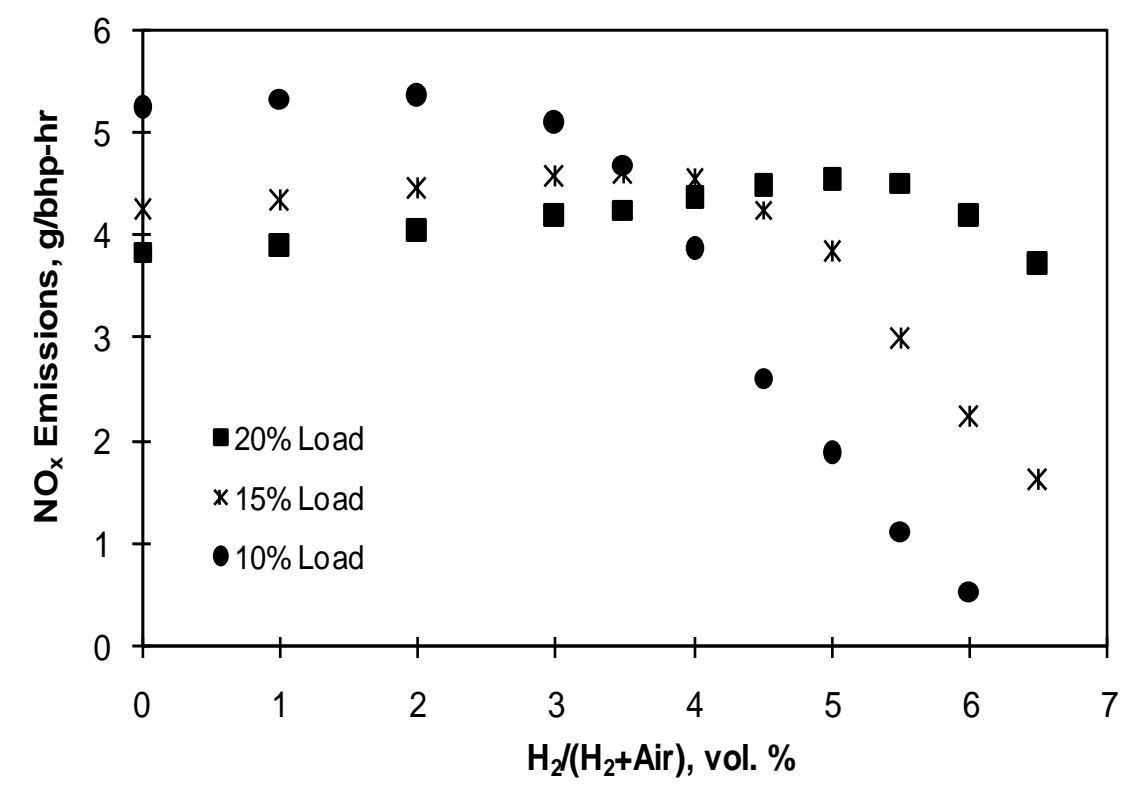

Figure 27 Effect of $\mathrm{H}_{2}$ Addition on $\mathrm{NO}_{\mathrm{x}}$ Emissions, $\mathrm{N}=1200 \mathrm{RPM}, 10-20 \%$ Load

As shown in Figure 28, the addition of a small amount of $\mathrm{H}_{2}$ at $15 \%$ load slightly reduced the averaged bulk mixture temperature accompanied with slightly increasing $\mathrm{NO}_{\mathrm{x}}$ emissions. This was not consistent with the traditional $\mathrm{NO}_{\mathrm{x}}$ formation mechanism. As shown in Figure 29, the addition of a small amount of $\mathrm{H}_{2}$ substantially enhanced the conversion of $\mathrm{NO}$ to $\mathrm{NO}_{2}$. As shown in Figure 28, the dramatic reduction in $\mathrm{NO}_{\mathrm{x}}$ emissions associated with the addition of a large amount of $\mathrm{H}_{2}$ at $15 \%$ load was due to the reduced bulk mixture temperature. The emission of $\mathrm{NO}, \mathrm{NO}_{2}$, and $\mathrm{NO}_{\mathrm{x}}$ were reduced. 


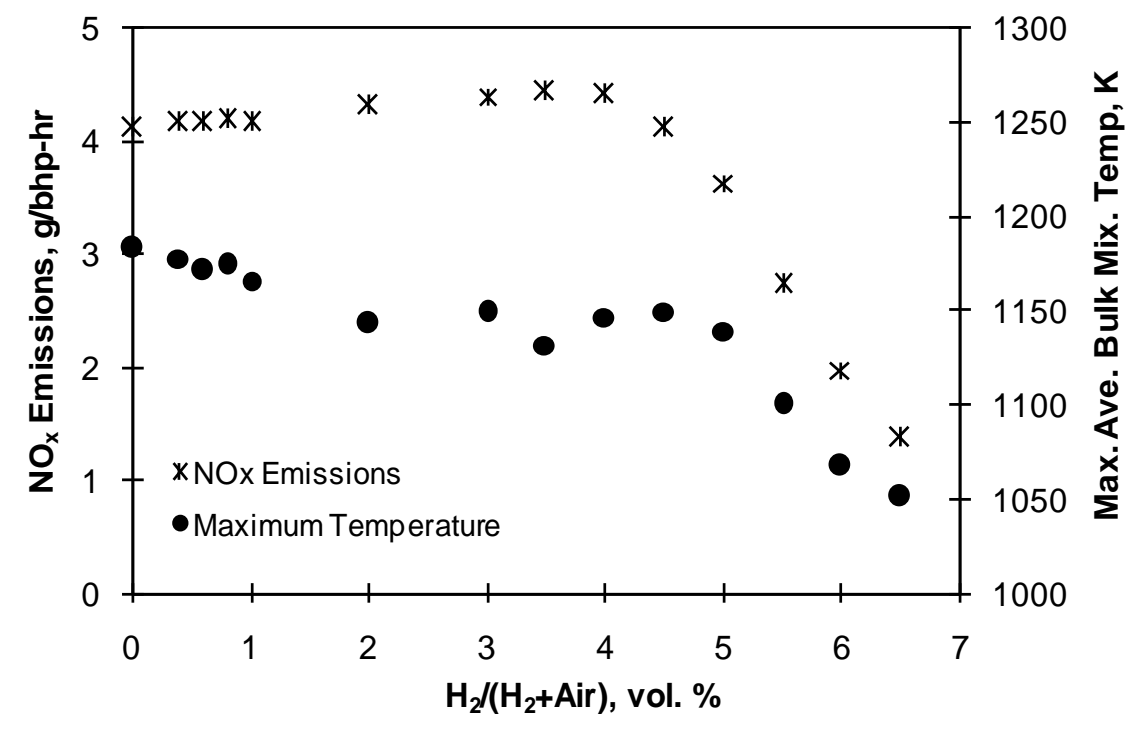

Figure 28 Effect of $\mathrm{H}_{2}$ Addition on $\mathrm{NO}_{\mathrm{x}}$ Emissions (mass) and Maximum Average Bulk Mixture Temperature, N=1200 RPM, 15\% Load

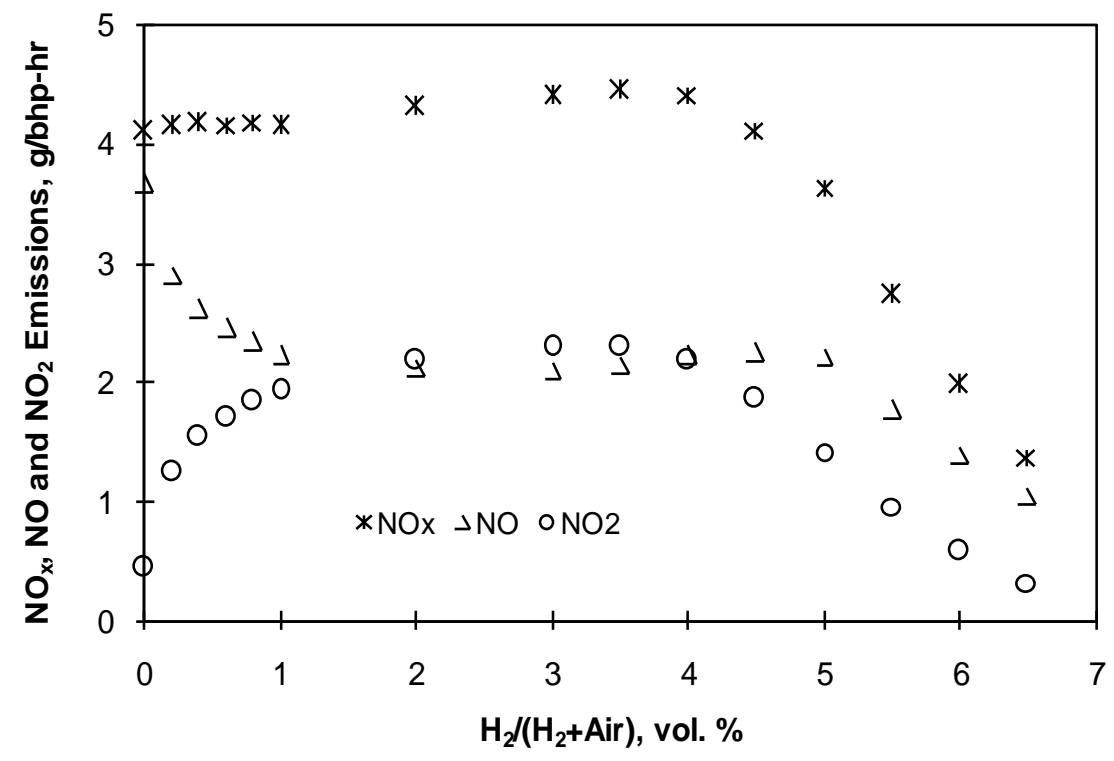

Figure 29 Effect of $\mathrm{H}_{2}$ Addition on the Emissions of $\mathrm{NO}_{x}, \mathrm{NO}$, and $\mathrm{NO}_{2}, \mathrm{~N}=1200 \mathrm{RPM}$, $15 \%$ Load 


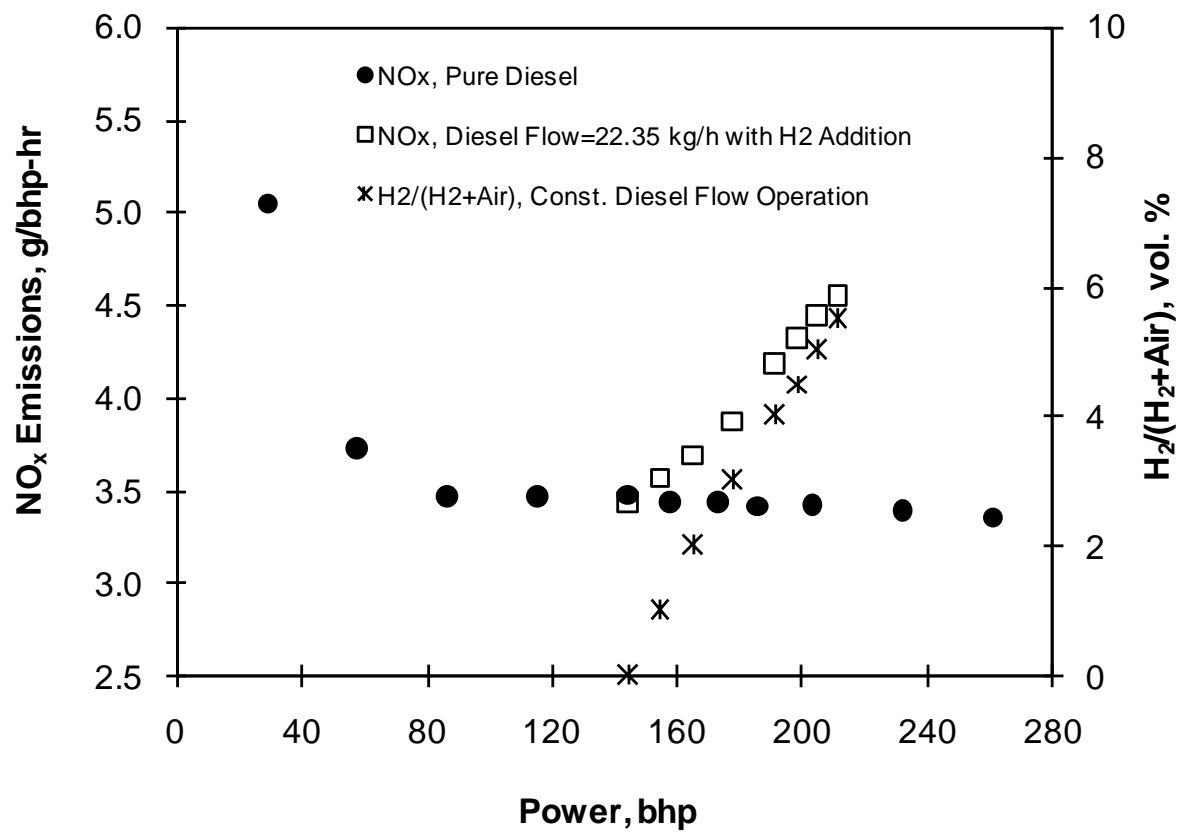

Figure 30 Effect of $\mathrm{H}_{2}$ Addition on $\mathrm{NO}_{\mathrm{x}}$ Emissions Operated with Constant Diesel Flow Rate of $22.45 \mathrm{~kg} / \mathrm{hr}$ (Corresponding to 50\% Load for Pure Diesel Operation). N=1200 RPM. For Constant Diesel Fuel Flow Rate Operation, Engine Load was varied by Adding $\mathrm{H}_{2}$

The enhancement of $\mathrm{H}_{2}$ on the $\mathrm{NO}_{\mathrm{x}}$ emissions was also examined under constant diesel flow rate. As shown in Figure 30, the addition of $\mathrm{H}_{2}$ under constant diesel flow rate increased substantially the emissions of $\mathrm{NO}_{\mathrm{x}}$.

\subsubsection{Effect of $\mathrm{H}_{2}$ Addition on the Emissions of PM}

The effect of $\mathrm{H}_{2}$ addition on the emissions of $\mathrm{PM}$ is shown in Figure 31 and Figure 32. As shown in Figure 31 for medium to high load operation, the emissions of PM were reduced gradually with the addition of $\mathrm{H}_{2}$ until $4.5 \% \mathrm{H}_{2}$ was added. Further increasing the amount of $\mathrm{H}_{2}$ had negligible effect on the PM emissions. 


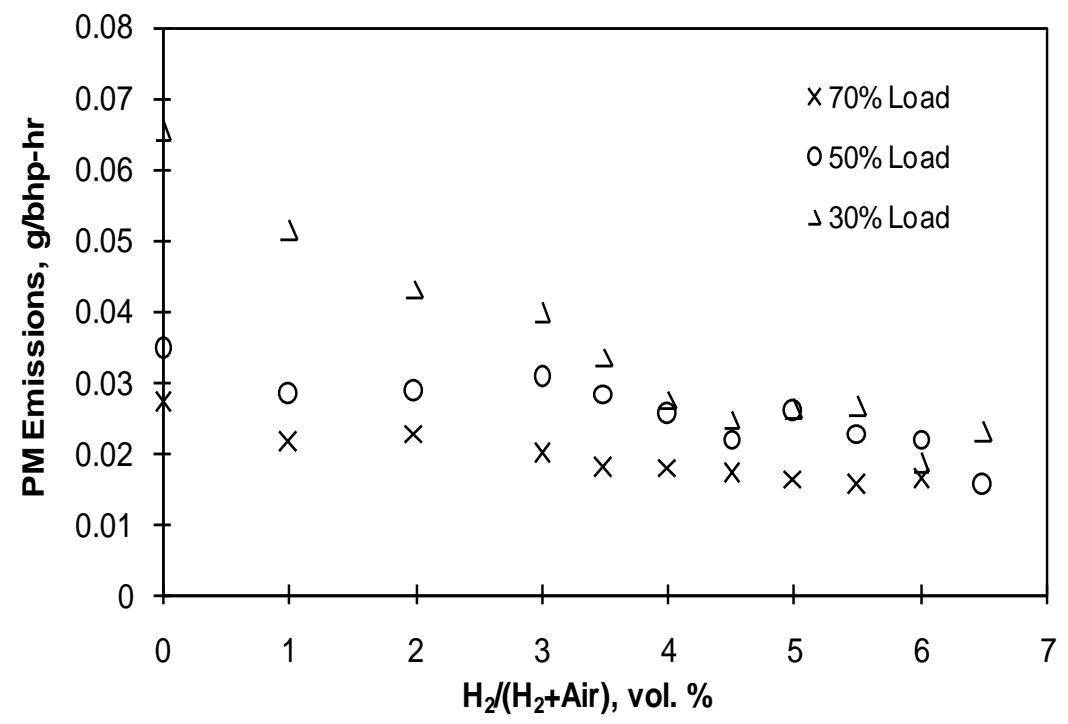

Figure 31 Effect of $\mathrm{H}_{2}$ Addition on PM Emissions, N=1200 RPM, 30-70\% Load

A similar trend was observed for the addition of the $\mathrm{H}_{2}$ under low load operation. As shown in Figure 32, the addition of up to $4.5 \% \mathrm{H}_{2}$ gradually reduced the emissions of PM. However, the addition of $\mathrm{H}_{2}$ beyond $4.5 \%$ increased the emissions of PM especially for $10 \%$ load. This may have been due to the burning of diesel in the hot bulk gases when the $\mathrm{H}_{2}$-air mixture was rich enough to support a fast propagating flame. The detailed explanation of this phenomenon may need further detailed experimental research. It was evident that the addition of $\mathrm{H}_{2}$ below 4\% reduced the PM emissions, which was consistent with those obtained in 13-mode emissions measurement. Compared to pure diesel operation, the maximum PM reduction obtained was 40 to $65 \%$ when operated from 10 to $70 \%$ load. 


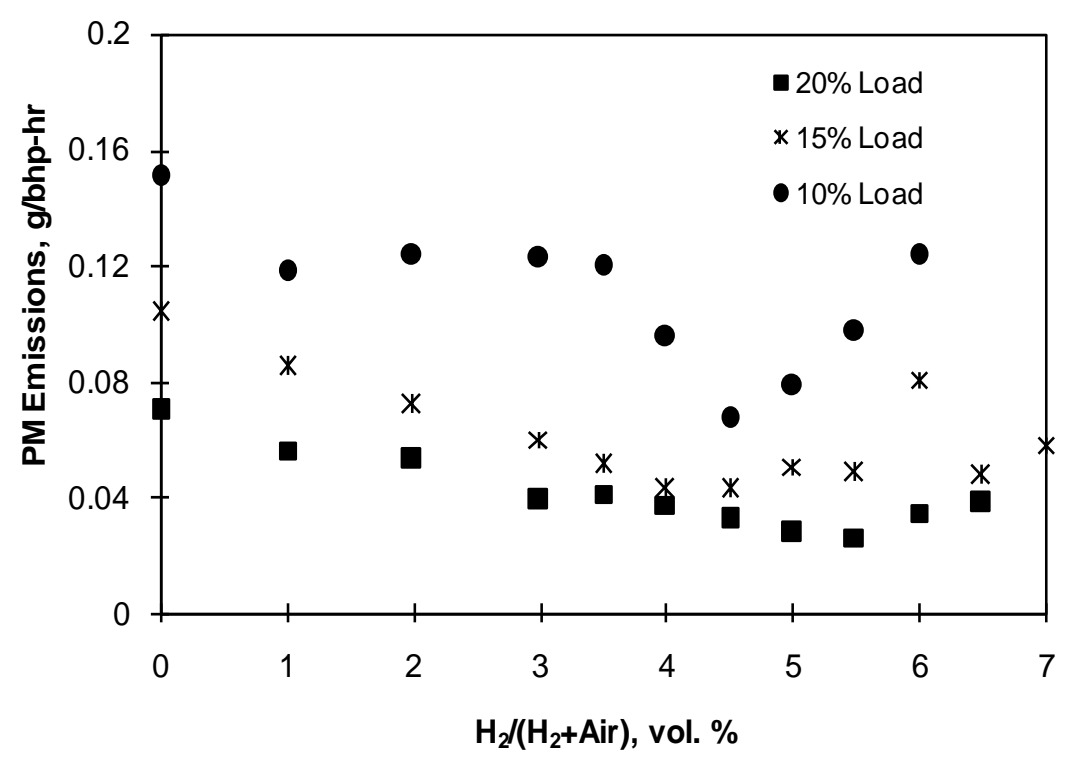

Figure 32 Effect of $\mathrm{H}_{2}$ Addition on PM Emissions, N=1200 RPM, 10-20\% Load

\subsubsection{Effect of $\mathrm{H}_{2}$ Addition on the Emissions of $\mathrm{CO}$}

$\mathrm{CO}$ is formed in the diesel engine due to the incomplete combustion of diesel fuels and also the dissociation of $\mathrm{CO}_{2}$ under high temperature conditions. As shown in Figure 33 and Figure 34, the CO emissions decreased almost linearly with the addition of $\mathrm{H}_{2}$ with the exception of 70\% load operation. As shown in Figure 33, the addition of $\mathrm{H}_{2}$ beyond 5\% at 20\% load started to increase the CO emissions. As shown in Figure 34 for $70 \%$ load operation, the addition of a small amount of $\mathrm{H}_{2}(<3.5 \%)$ had a negligible effect on $\mathrm{CO}$ emissions. Increasing the amount of $\mathrm{H}_{2}$ beyond $4 \%$ increased the $\mathrm{CO}$ emissions. 


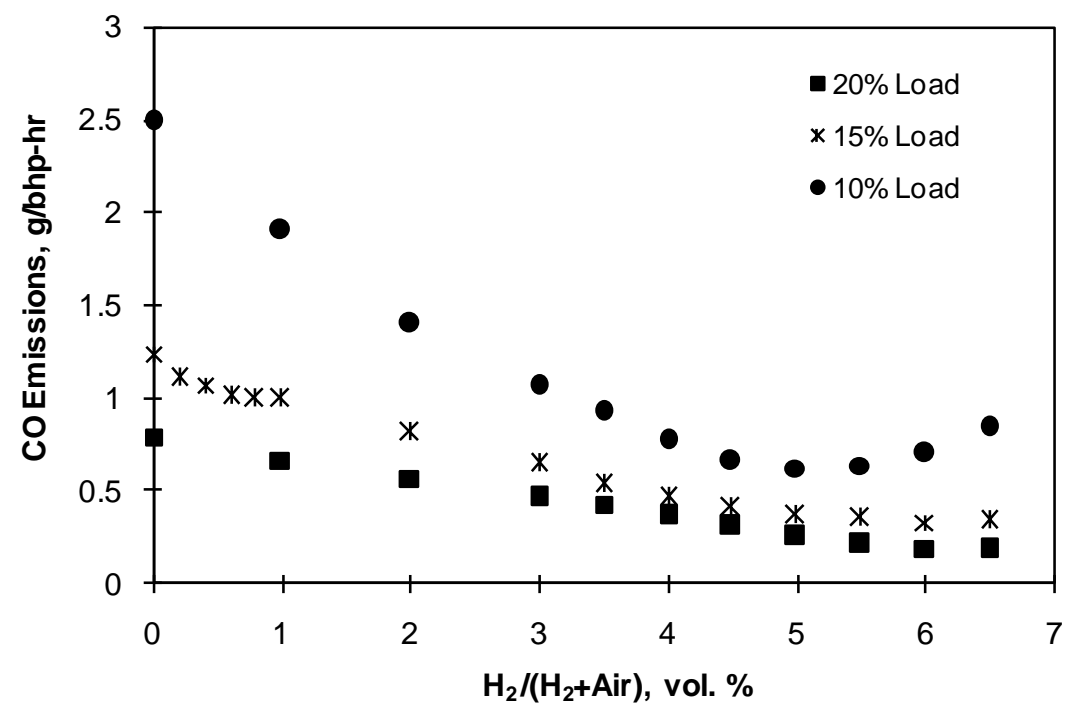

Figure 33 Effect of $\mathrm{H}_{2}$ Addition on CO Emissions, N=1200 RPM, 10-20\% Load

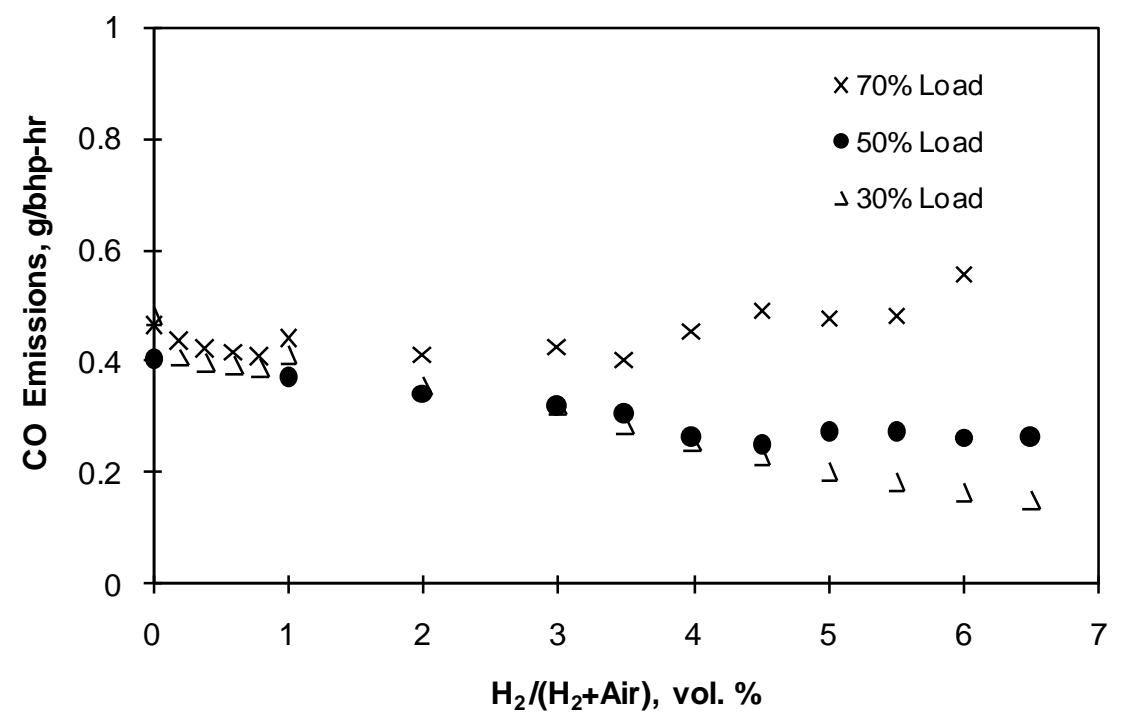

Figure 34 Effect of $\mathrm{H}_{2}$ Addition on CO Emissions, N=1200 RPM, 30-70\% Load

\subsubsection{Effect of $\mathrm{H}_{2}$ Addition on the Emissions of $\mathrm{HC}$}

The effect of $\mathrm{H}_{2}$ addition on $\mathrm{HC}$ emissions is shown Figure 35 and Figure 36. As shown in Figure 35, the addition of $\mathrm{H}_{2}$ at low load slightly increased the $\mathrm{HC}$ emissions. When operated at medium to high load, the effect of $\mathrm{H}_{2}$ addition on $\mathrm{HC}$ emissions was 
very small as shown in Figure 36. This was consistent with the results reported in the 13mode ESC, which showed a very small effect of $\mathrm{H}_{2}$ on $\mathrm{HC}$ emissions.

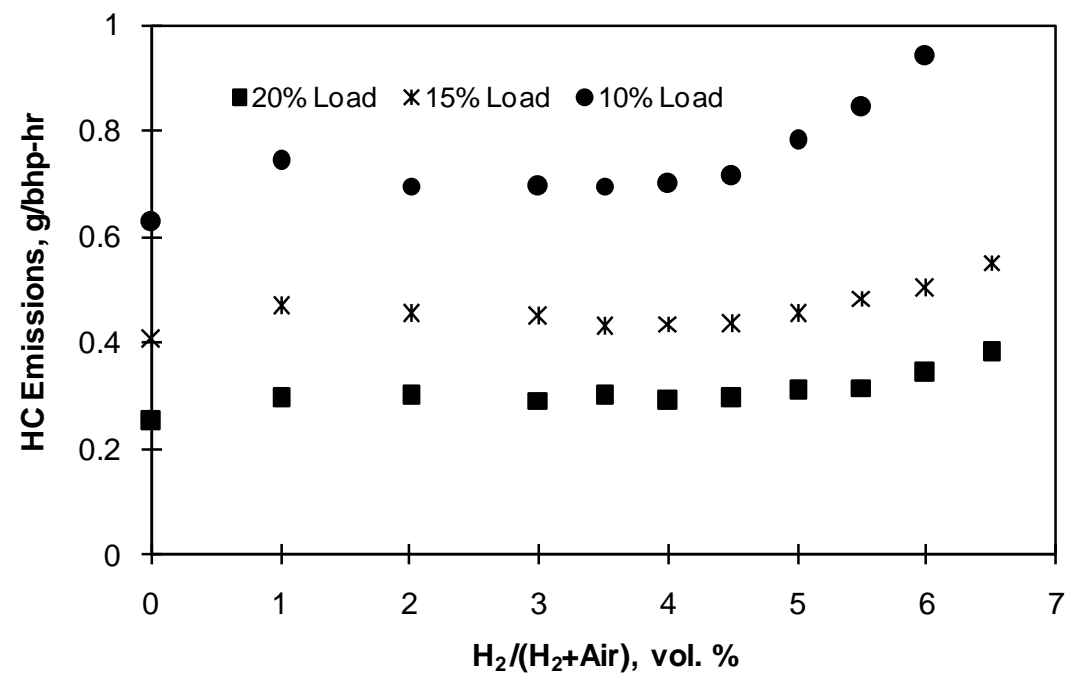

Figure 35 Effect of $\mathrm{H}_{2}$ Addition on HC Emissions, N=1200 RPM, 10-20\% Load

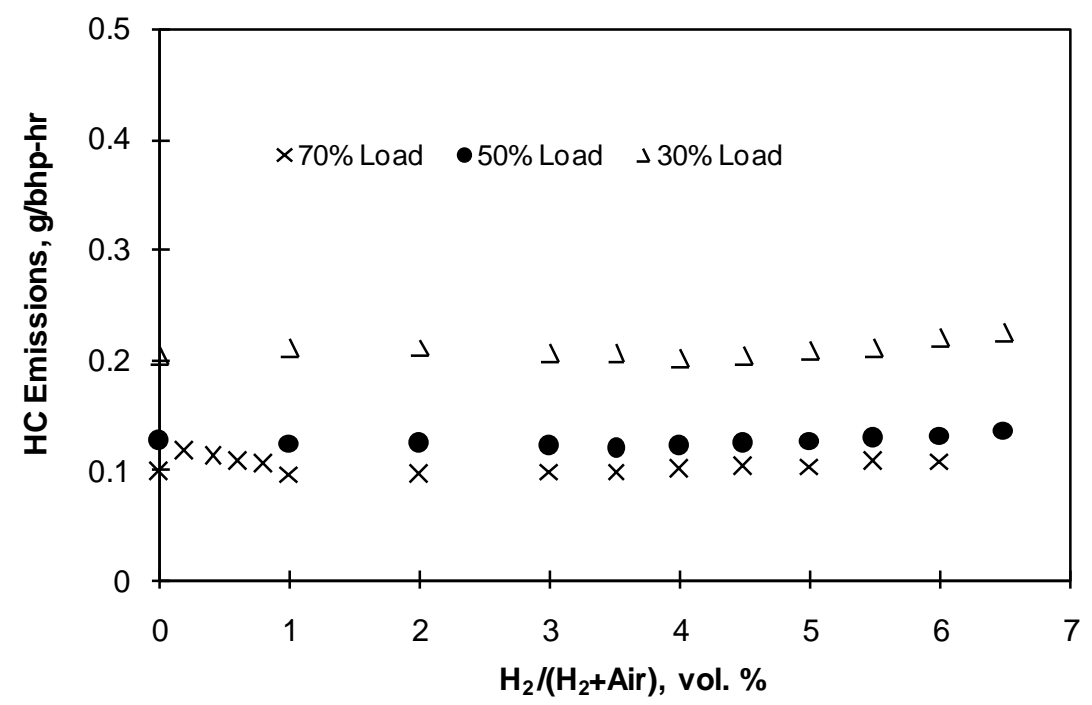

Figure 36 Effect of $\mathrm{H}_{2}$ Addition on HC Emissions, N=1200 RPM, 30-70\% Load 


\subsubsection{Effect of $\mathrm{H}_{2}$ Addition on the Emissions of $\mathrm{CO}_{2}$}

The effect of $\mathrm{H}_{2}$ addition on $\mathrm{CO}_{2}$ emissions is shown in Figure 37. The addition of $\mathrm{H}_{2}$ into the diesel engine gradually reduced the $\mathrm{CO}_{2}$ emissions. With the addition of a small amount of $\mathrm{H}_{2}$, the operation at high load produced less $\mathrm{CO}_{2}$ than low load operation due to the higher BTE at higher load operation. With the addition of $4 \% \mathrm{H}_{2}$ into the intake mixture, the $\mathrm{CO}_{2}$ emissions obtained were comparable for the range of engine load examined. Further increasing the condition of $\mathrm{H}_{2}$, the operation at lower load produced less $\mathrm{CO}_{2}$ than higher load operation. This was due mainly to the substitution of higher percentage of diesel fuel by $\mathrm{H}_{2}$ for lower load operation. As shown in Table 8, the addition of $6 \% \mathrm{H}_{2}$ to intake mixture contributed to $92.1 \%$ of the total intake energy. When operated at $70 \%$ load, the addition of $6 \% \mathrm{H}_{2}$ contributed to $31.7 \%$ of the total intake energy.

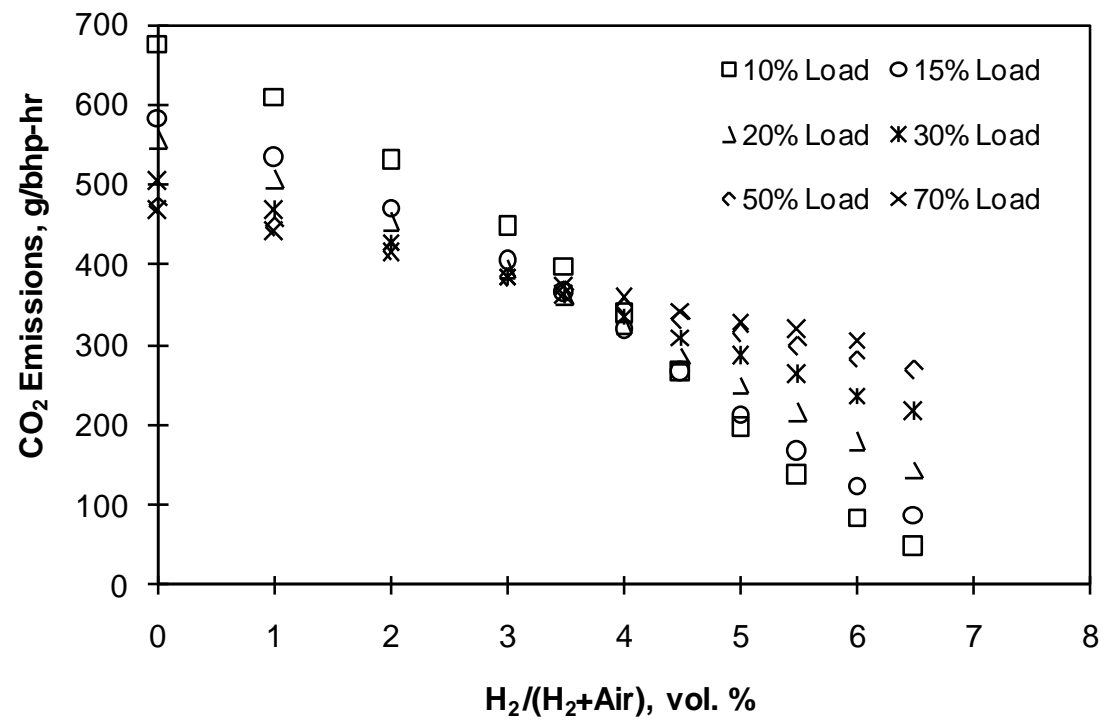

Figure 37 Effect of $\mathrm{H}_{2}$ Addition on $\mathrm{CO}_{2}$ Emissions, $\mathrm{N}=1200$ RPM, 10-70\% Load 


\subsection{Brake Thermal Efficiency and Its Improvement}

As shown in Figure 38 for 30\% load operation, the addition of a small amount of $\mathrm{H}_{2}$ reduced the BTE with its minimum value observed with the addition of $2 \% \mathrm{H}_{2}$. The addition of $\mathrm{H}_{2}$ beyond 2\% started to improve the BTE. With the addition of $3.5 \% \mathrm{H}_{2}$, the BTE obtained was comparable to that of pure diesel operation. With the addition of $6.5 \%$ $\mathrm{H}_{2}$ into the intake mixture, the BTE obtained was $41.9 \%$, a much better value than $38.9 \%$ obtained for pure diesel operation. The BTE of $\mathrm{H}_{2}$-diesel dual fuel operation was further processed to calculate the improvement to the BTE relative to pure diesel operation. As shown in Figure 38, the addition of $\mathrm{H}_{2}$ beyond 3\% improved the BTE. The addition of 6.5\% $\mathrm{H}_{2}$ improved the brake thermal efficiency by 7.7\% (relative).

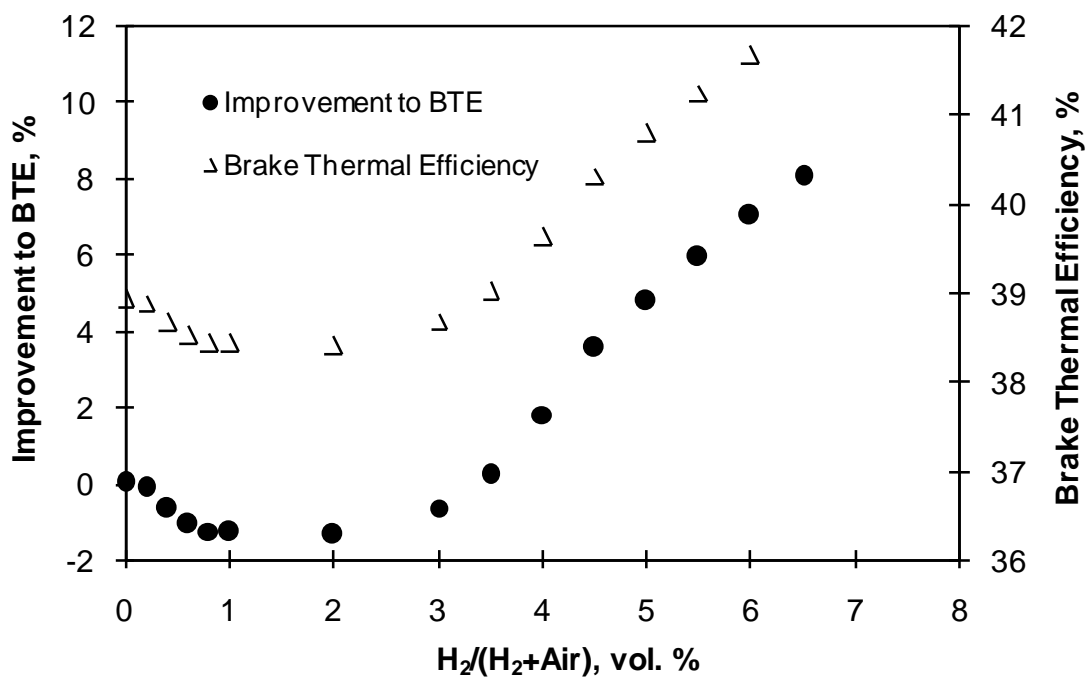

Figure 38 Effect of $\mathrm{H}_{2}$ Addition on BTE and Its Improvements, N=1200 RPM, 30\% Load

As shown in Figure 39, the addition of $\mathrm{H}_{2}$ at $10 \%$ load was shown to reduce the BTE. When operated at higher load, the addition of a relatively large amount of $\mathrm{H}_{2}$ improved the BTE. It was evident that there was a minimum $\mathrm{H}_{2}$ addition rate, beyond which a positive effect on BTE was obtained. Such a rate was defined as the minimum $\mathrm{H}_{2}$ 
addition limit. For example, improved BTE was obtained with the addition of $\mathrm{H}_{2}$ beyond 4.5 at $15 \%$ load operation. When operated at $50 \%$ load, the addition of $\mathrm{H}_{2}$ over $1 \%$ improved the BTE.

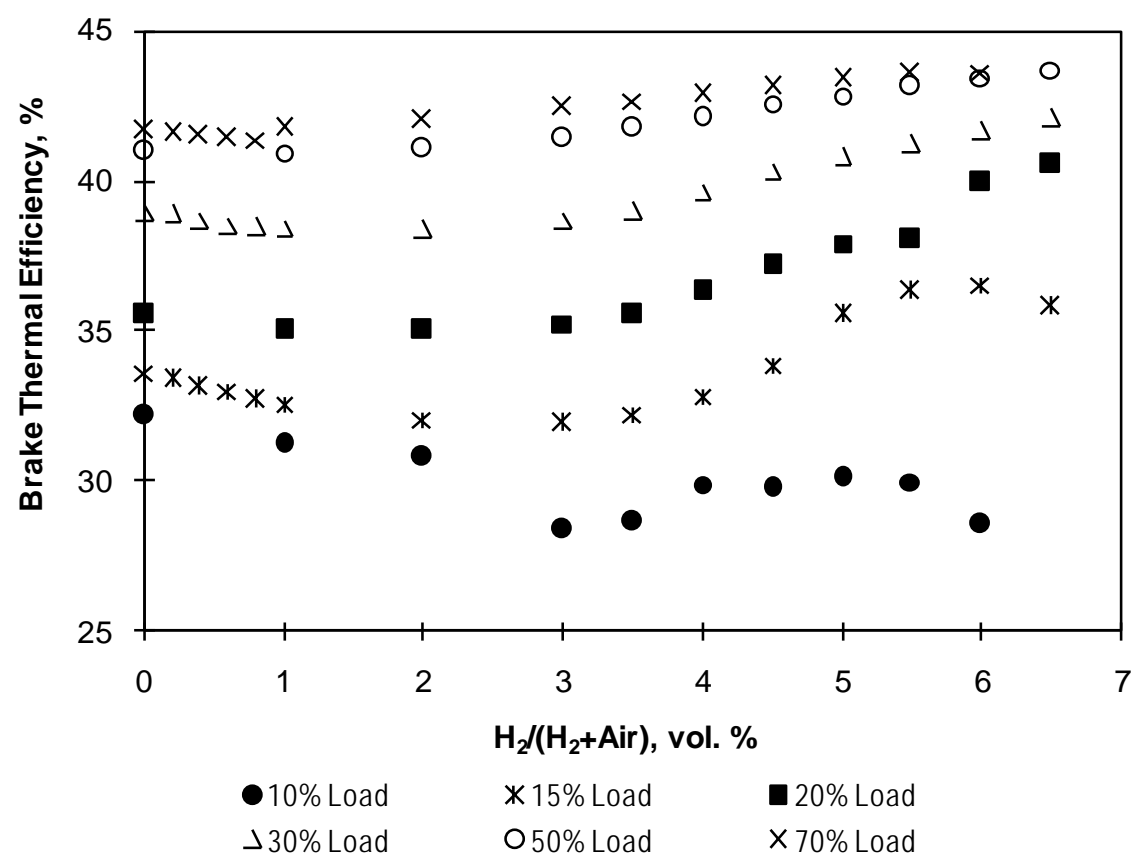

Figure 39 Effect of $\mathrm{H}_{2}$ Addition and Engine Load on the Improvement to BTE, N=1200 RPM, 10-70\% Load

As shown in Figure 40, with the increased engine load, the $\mathrm{H}_{2}$ addition limit to obtain a positive effect in improving the BTE expanded toward lower $\mathrm{H}_{2}$ concentration. For example, the addition of $\mathrm{H}_{2}$ beyond 3\% improved BTE when operated at 20\% load. When operated at 50\% load, the improved BTE could be obtained with the addition of $\mathrm{H}_{2}$ beyond $1 \%$. It was evident that the operation under lower load required the addition of more $\mathrm{H}_{2}$ to obtain an improvement to the BTE.

Figure 41 shows the effect of $\mathrm{H}_{2}$ addition on the improvement of the BTE. The maximum improvement to the BTE of $14.1 \%$ was obtained at $20 \%$ load operation with the addition of $6.5 \% \mathrm{H}_{2}$. 


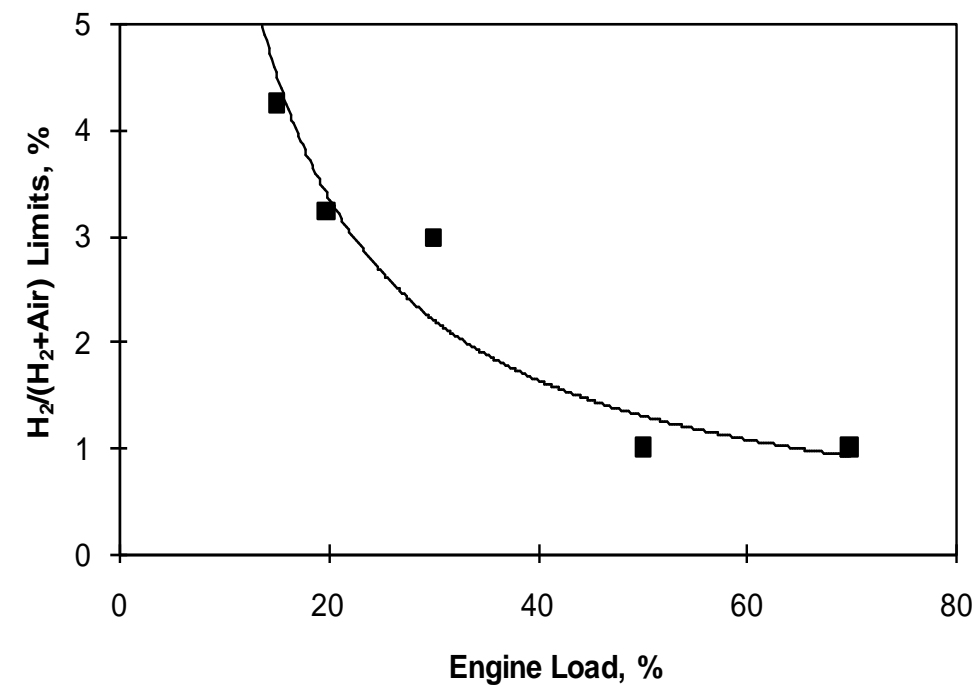

Figure 40 Effect of Engine Load on the Minimum $\mathrm{H}_{2}$ Supplementation Rate Needed for Positive Effect on the BTE

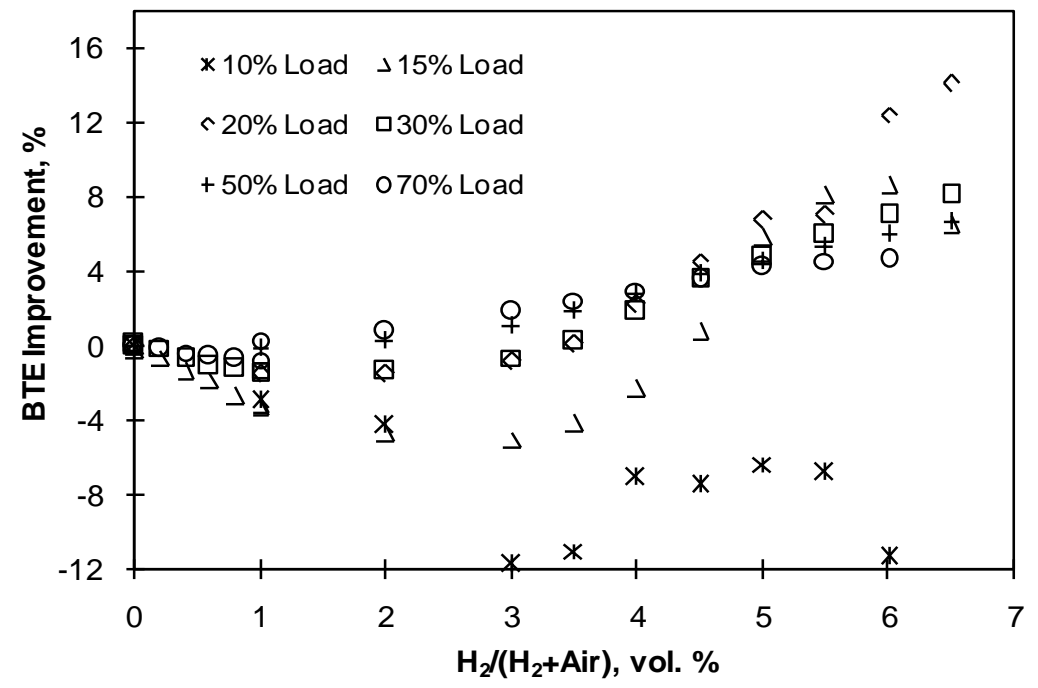

Figure 41 Effect of $\mathrm{H}_{2}$ Addition in Improving the BTE, N=1200 RPM, 10-70\% Load

As shown in Figure 42 for the addition of $6 \% \mathrm{H}_{2}$, the improvement to the BTE was found to decrease with the increased engine load with the exception of $10 \%$ load operation. The addition of $\mathrm{H}_{2}$ at $10 \%$ load operation did not improve the BTE. The effect of the engine speed and the $4 \% \mathrm{H}_{2}$ addition on the BTE is shown in Figure 43 . The engine speed had negligible effect on the improvement to the BTE resulted from the 
addition of $4 \% \mathrm{H}_{2}$. The addition of $4 \% \mathrm{H}_{2}$ improved the BTE by $3.7 \%$ for the range of engine speed examined.

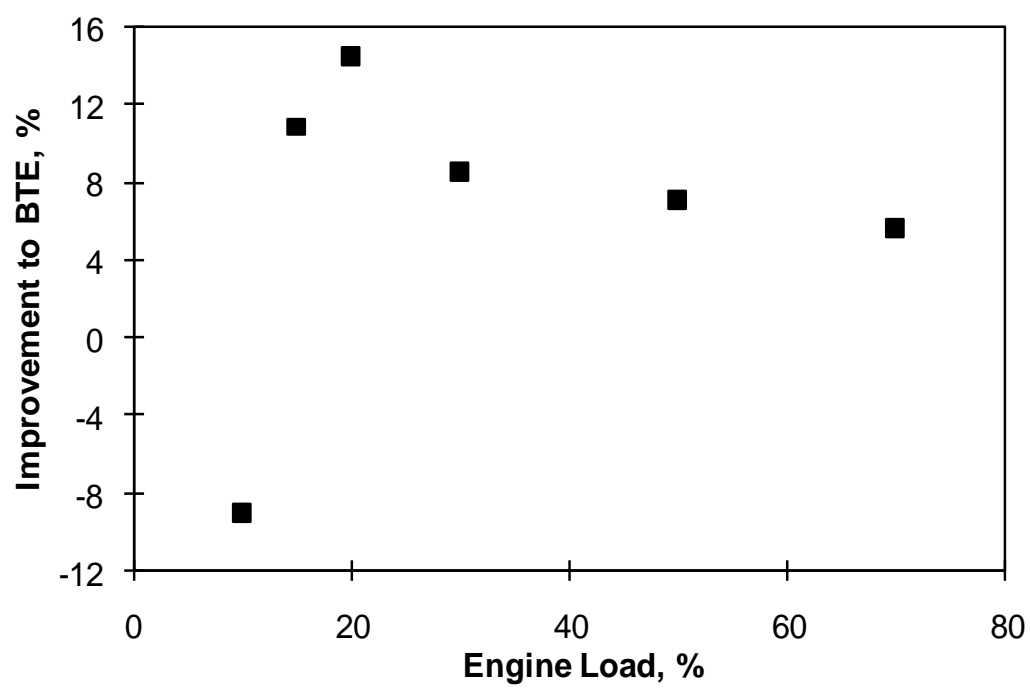

Figure 42 Effect of Engine Load on the Improvement to BTE with the Addition of 6\% $\mathrm{H}_{2}, \mathrm{~N}=1200 \mathrm{RPM}$

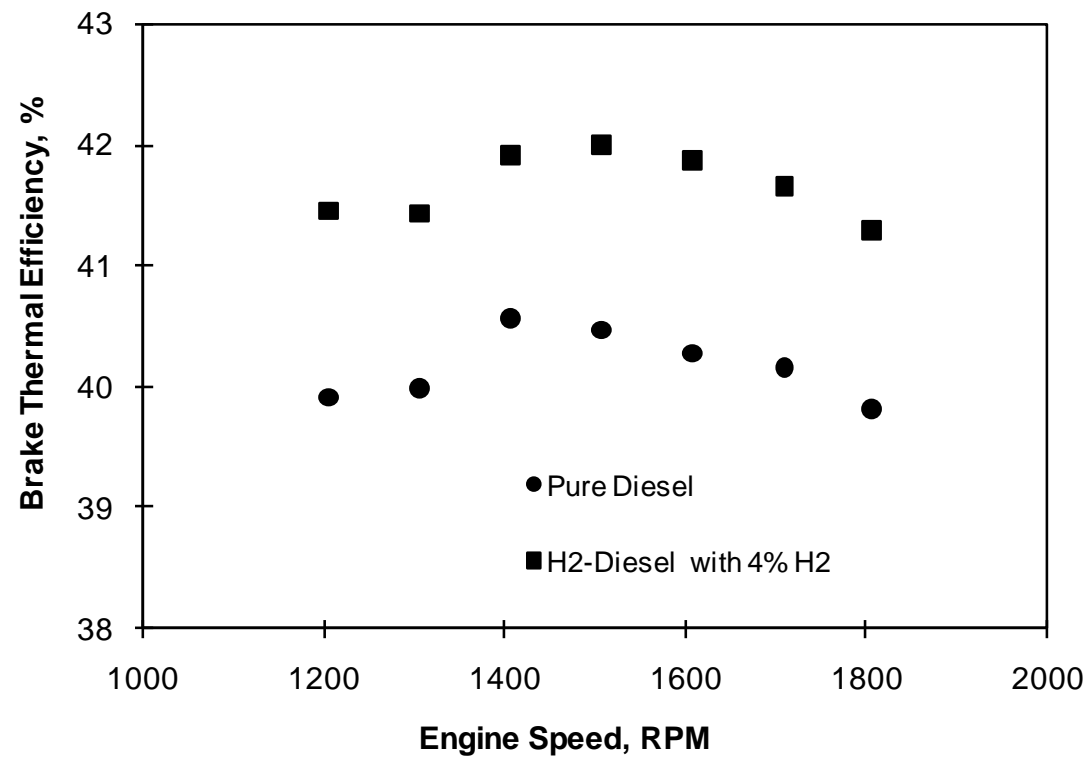

Figure 43 Effect of $\mathrm{H}_{2}$ Addition and Engine Speed on BTE and Improvement, Torque $=700 \mathrm{ft}-\mathrm{lb}$, Pure Diesel and $\mathrm{H}_{2} /\left(\mathrm{H}_{2}+\mathrm{Air}\right)=4 \%$, vol. 
The effect of $\mathrm{H}_{2}$ addition on the BTE was also investigated while the diesel fuel flow rate was held constant. The engine load was increased by gradually adding more $\mathrm{H}_{2}$ into the intake mixture. Compared to pure diesel operation, the addition of a small amount of $\mathrm{H}_{2}$ reduced the BTE as shown in Figure 44 . With the addition of $2 \% \mathrm{H}_{2}$, the BTE obtained was comparable to that of pure diesel operation. Further increasing the addition of $\mathrm{H}_{2}$ beyond 2\% substantially improved the BTE. The maximum BTE of $44.8 \%$ was obtained with the addition of $5.5 \% \mathrm{H}_{2}$. Compared to the BTE of $41.6 \%$ obtained with pure diesel operation at same load, the BTE was increased by 7.7\% (relative).

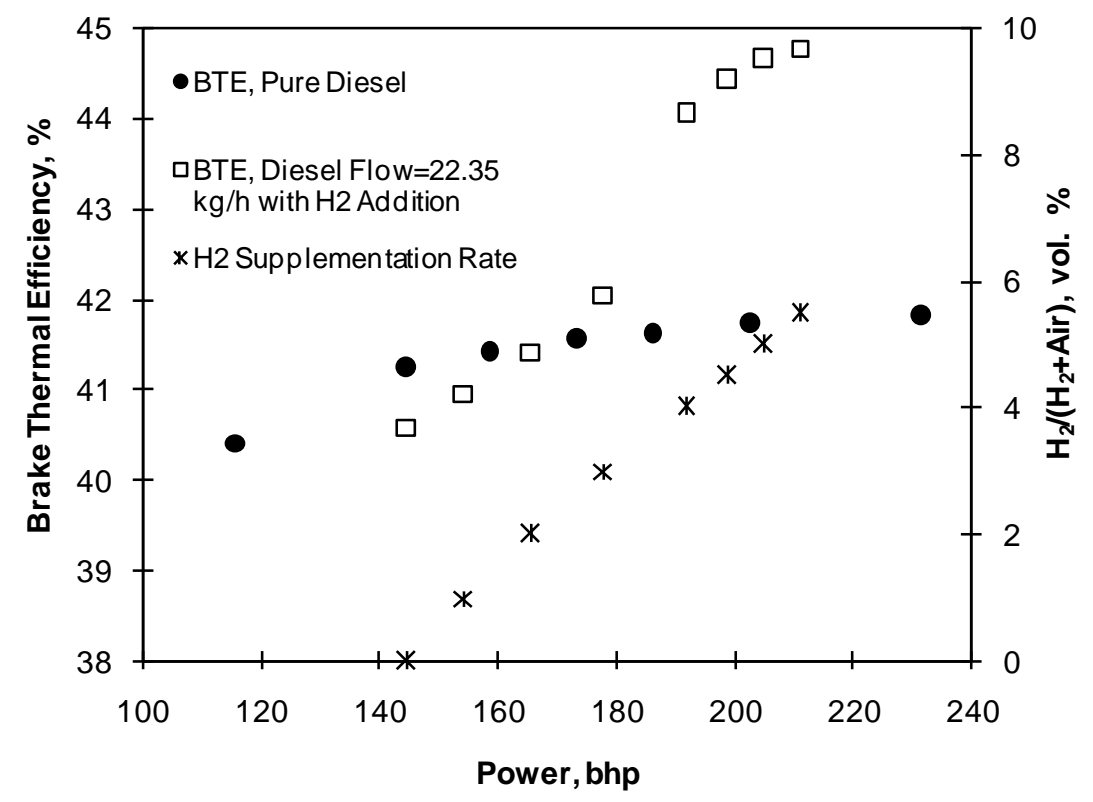

Figure 44 Effect of $\mathrm{H}_{2}$ Addition on BTE, N=1200 RPM for Constant Diesel Flow Operation, Engine Load Was Increased by the Addition of $\mathrm{H}_{2}$

\subsection{Effect of $\mathrm{H}_{2}$ Addition on Cylinder Pressure and Heat Release Process}

Figure 45 shows the effect of $\mathrm{H}_{2}$ addition on cylinder pressure when operated at $70 \%$ load. With the addition of a relatively small amount $(<3 \%)$ of $\mathrm{H}_{2}$, the cylinder pressure prior to the initiation of combustion was found to be higher than that of pure 
diesel operation. This was due to the increased intake pressure as shown in Figure 46. The maximum intake pressure was observed with the addition of $2 \% \mathrm{H}_{2}$. Further increasing the addition of $\mathrm{H}_{2}$ beyond $2 \%$ gradually reduced the intake pressure and also the cylinder pressure prior to the initiation of combustion. As shown in Figure 45, the addition of $\mathrm{H}_{2}$ substantially increased the cylinder pressure after the combustion was initiated. This was further demonstrated by examining the effect of $\mathrm{H}_{2}$ addition on the peak cylinder pressure. As shown in Figure 47, the addition of a small amount of $\mathrm{H}_{2}$ slightly increased the peak cylinder pressure with negligible effect on the phasing when peak cylinder pressure was observed. Further increasing the addition of $\mathrm{H}_{2}$ beyond 3\% substantially increased the peak cylinder pressure. The addition of $6 \% \mathrm{H}_{2}$ increased the peak cylinder pressure from 107.2 to 120.9 bar. As shown in Figure 47, the addition of $\mathrm{H}_{2}$ beyond 3.5\% gradually advanced the phasing when peak cylinder pressure was observed.

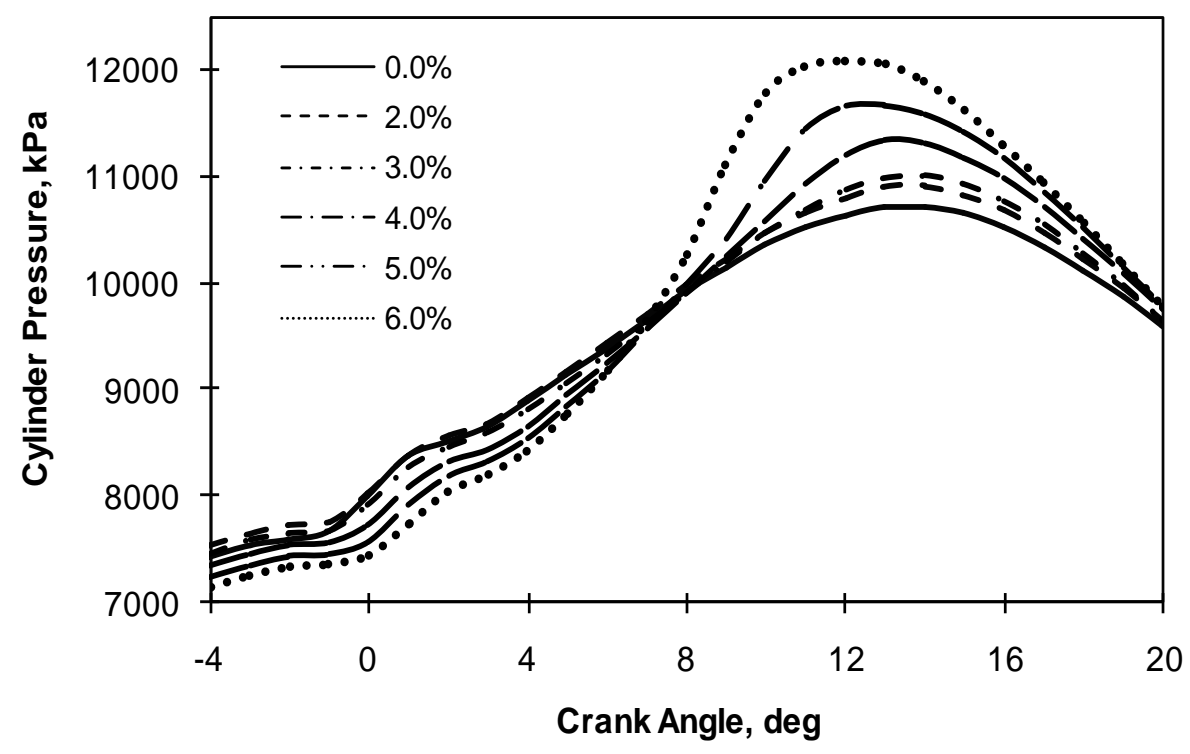

Figure 45 Effect of $\mathrm{H}_{2}$ Addition on Cylinder Pressure, N=1200 RPM, 70\% Load 


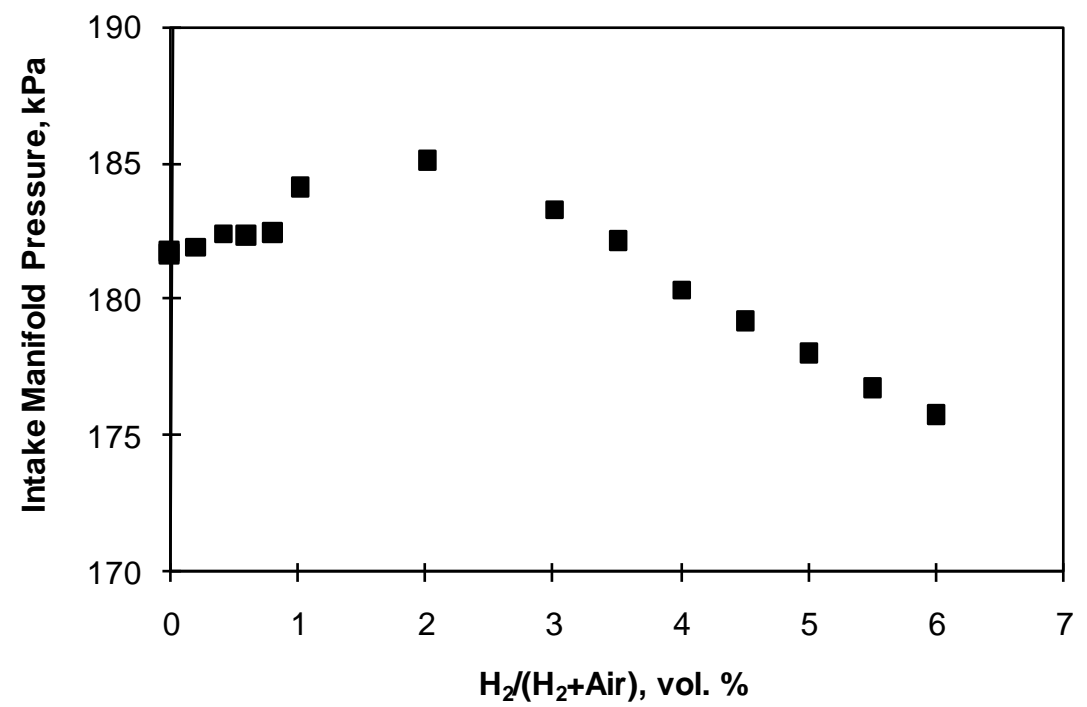

Figure 46 Effect of $\mathrm{H}_{2}$ Addition on Intake Manifold Pressure, N=1200 RPM, 70\% Load

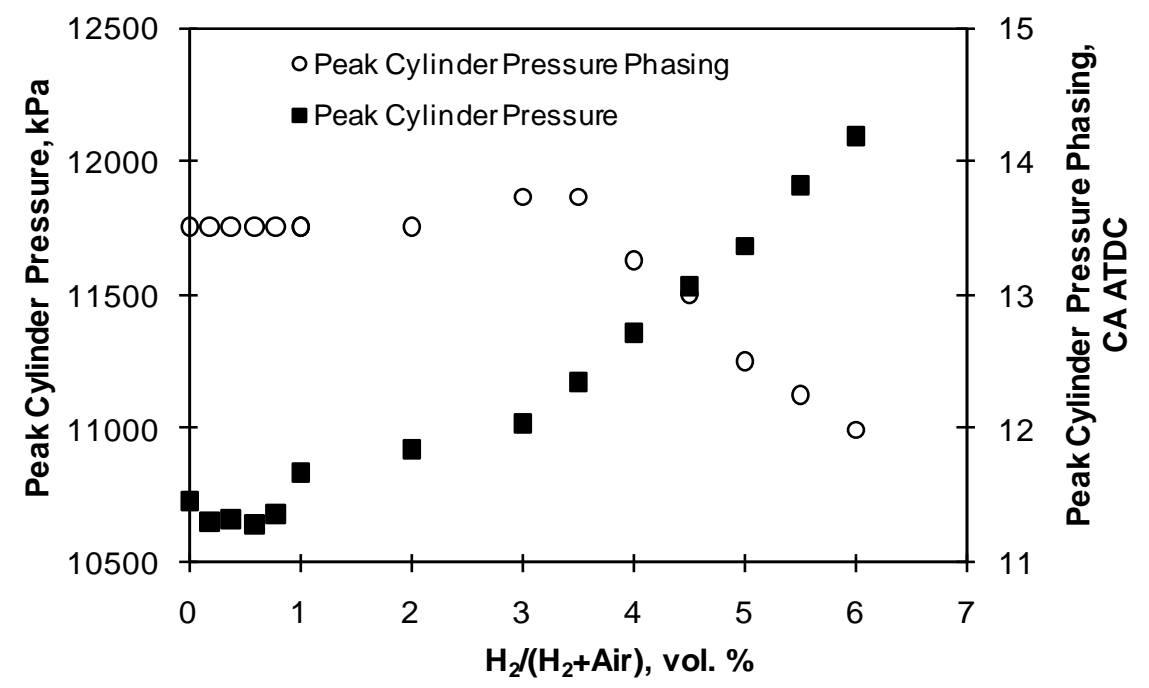

Figure 47 Effect of $\mathrm{H}_{2}$ Addition on Peak Cylinder Pressure and Its Phasing, N=1200 RPM, 70\% Load

The cylinder pressure was processed to obtain the heat release rate. As shown in Figure 48 for the premixed combustion, the addition of $\mathrm{H}_{2}$ slightly retarded the initiation of premixed combustion and reduced the peak heat release rate observed in the premixed combustion stage. As shown in Figure 49, the addition of $\mathrm{H}_{2}$ into this diesel engine enhanced the mixing controlled diffusion combustion process. When a large amount of 
$\mathrm{H}_{2}(>4 \%)$ was added, the traditional two-stage combustion process of diesel operation as shown in Figure 50, developed to a three-stage combustion process featured with a significantly enhanced heat release peak observed at the middle of diffusion combustion. This was further demonstrated in Figure 51 for the addition of $6 \% \mathrm{H}_{2}$. Following the premixed combustion, the diffusion combustion of the $\mathrm{H}_{2}$-diesel dual fuel engine was initiated by the continuous injection, atomization, vaporization, and mixing of diesel fuel with air, followed by an extremely high heat release rate beyond that observed in traditional diesel diffusion combustion. It was believed that such a "huge" heat release peak was due to the initiation of multi $\mathrm{H}_{2}$-air flames, which burned the $\mathrm{H}_{2}$ quickly through the propagation of multi turbulent flames. The combination of the diesel diffusion combustion and the turbulent flames of $\mathrm{H}_{2}$-air fuel mixture created the high heat release peak observed in $\mathrm{H}_{2}$-diesel dual fuel combustion. After the turbulent $\mathrm{H}_{2}$-air flames propagated through the entire bulk mixture or quenched due to the slow reaction rate, the diffusion combustion of diesel continued until completion, noted as late diesel diffusion combustion. As shown in Figure 50 and Figure 51, the peak heat release rate of $\mathrm{H}_{2}$-diesel dual fuel engine was over two times that of pure diesel combustion. In comparison, the diffusion combustion of pure diesel operation was relatively "flat". As shown in Figure 51, the dual fuel diesel engine combustion consisted of premixed diesel combustion, early stage diffusion combustion of diesel, burning of $\mathrm{H}_{2}$ by multi turbulent flames and late state diffusion combustion of diesel fuel. 


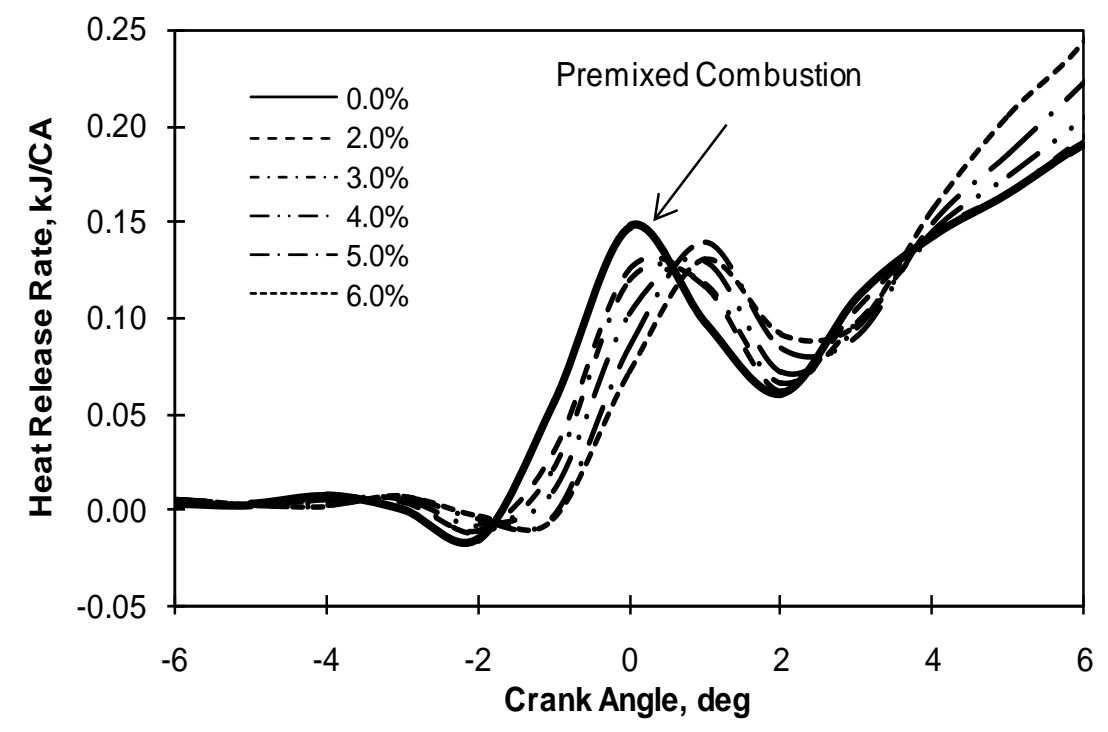

Figure 48 Effect of $\mathrm{H}_{2}$ Addition on Heat Release Rate of Premixed Combustion, N=1200 RPM, 70\% Load

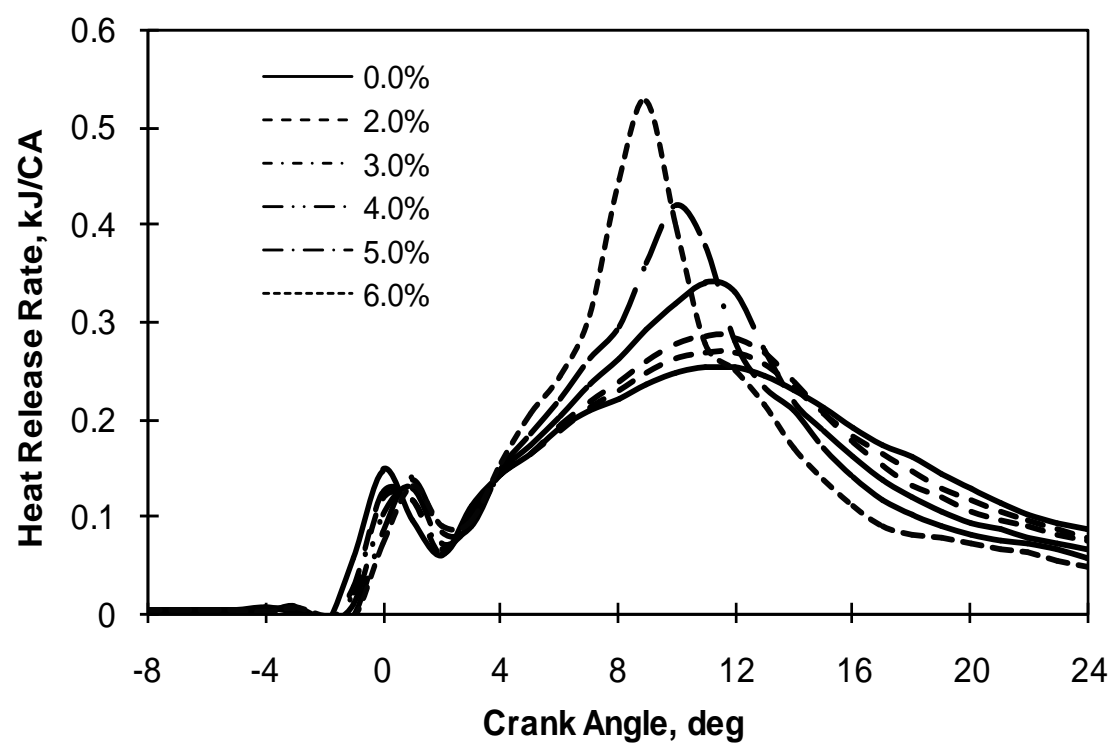

Figure 49 Effect of $\mathrm{H}_{2}$ Addition on Heat Release Rate, N=1200 RPM, 70\% Load 


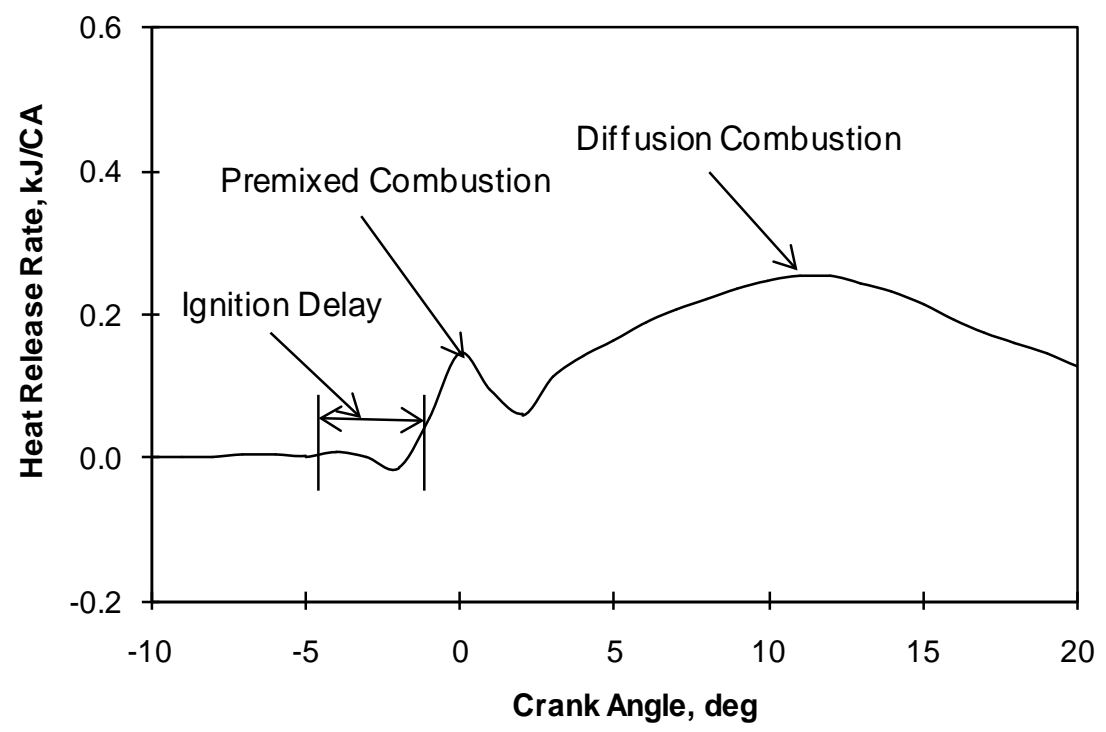

Figure 50 The Two-Stage Heat Release Process of Pure Diesel Operation, N=1200 RPM, $70 \%$ Load

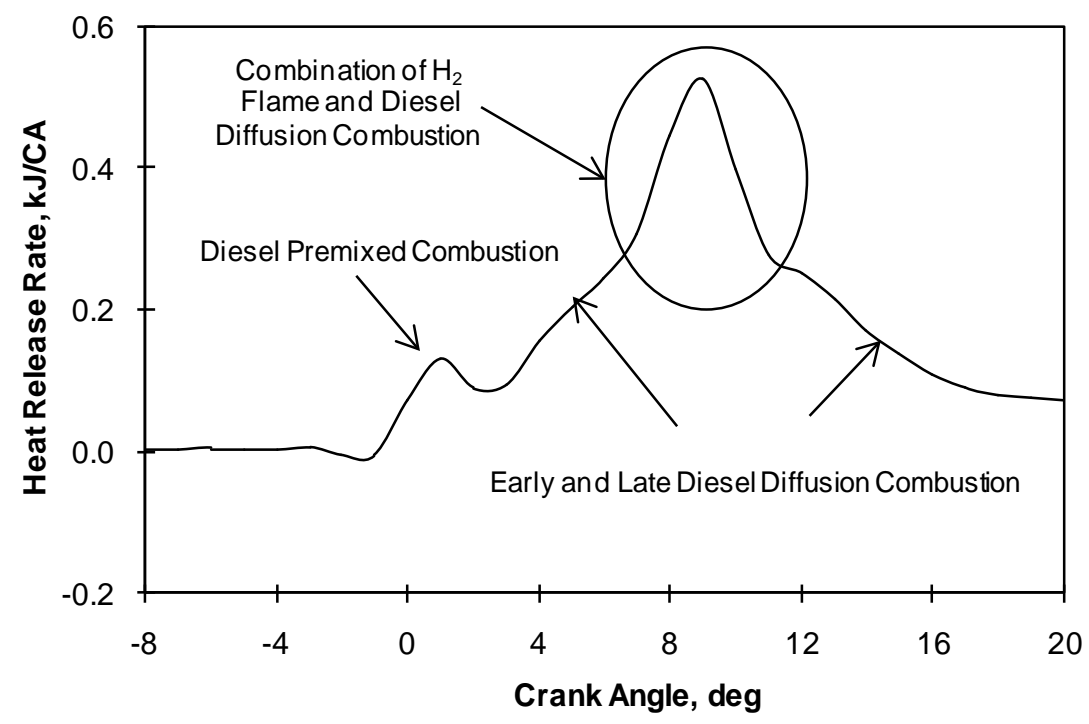

Figure 51 The Three-Stage Heat Release Process of $\mathrm{H}_{2}$-Diesel Dual Fuel Engine, $\mathrm{N}=1200$ RPM, 70\% Load, $\mathrm{H}_{2} /\left(\mathrm{H}_{2}+\mathrm{Air}\right)=6 \%$, vol.

As shown in Figure 50, the start of injection (SOI) was defined as the crank angle when the first tiny "heat release" bump associated with diesel injection was observed. The start of combustion (SOC) was defined as the crank angle when the heat release rate at premixed stage reached $0.05 \mathrm{~kJ} / \mathrm{deg} \mathrm{CA}$. The crank angle period between the SOI and 
SOC was defined as the ignition delay. As shown in Table 15, the addition of $\mathrm{H}_{2}$ was found slightly retarded the SOC. Compared to pure diesel operation, the addition of $6 \%$ $\mathrm{H}_{2}$ retarded the SOC by approximately 0.84 deg CA. In comparison, the effect of the addition of $\mathrm{H}_{2}$ on ignition delay was small. With addition of $\mathrm{H}_{2}$ at $70 \%$ load, the retardation of the premixed combustion was due mainly to the retarded fuel injection.

Table 15 Effect of $\mathrm{H}_{2}$ Addition on SOI, SOC, and Ignition Delay (ID) When Operated at 1200 RPM, 70\% Load

\begin{tabular}{|c|c|c|c|}
\hline $\begin{array}{c}\mathbf{H}_{2} /\left(\mathbf{H}_{2}+\text { Air), vol. }\right. \\
\mathbf{\%}\end{array}$ & SOI, CA ATDC & SOC, CA ATDC & $\begin{array}{c}\text { Ignition Delay, } \\
\text { CA }\end{array}$ \\
\hline 0 & -5.20 & -1.10 & 4.10 \\
\hline 1 & -5.10 & -0.85 & 4.25 \\
\hline 2 & -5.05 & -0.75 & 4.30 \\
\hline 3 & -5.00 & -0.68 & 4.32 \\
\hline 4 & -4.90 & -0.55 & 4.35 \\
\hline 5 & -4.40 & -0.37 & 4.03 \\
\hline 6 & -4.20 & -0.26 & 3.94 \\
\hline
\end{tabular}

As shown in Figure 52, the addition of a small amount of $\mathrm{H}_{2}(<3 \%)$ slightly enhanced the peak heat release rate without affecting the phasing when peak heat release rate was observed. However, further increasing the addition of $\mathrm{H}_{2}$ beyond 3.5\% substantially increased the peak heat release rate and also advanced the phasing when the peak heat release rate was observed. This was due to the gradual development of the turbulent $\mathrm{H}_{2}$ flame at the early stage of diesel diffusion combustion, which released more energy at advanced phasing as shown in Figure 49 and Figure 51. 


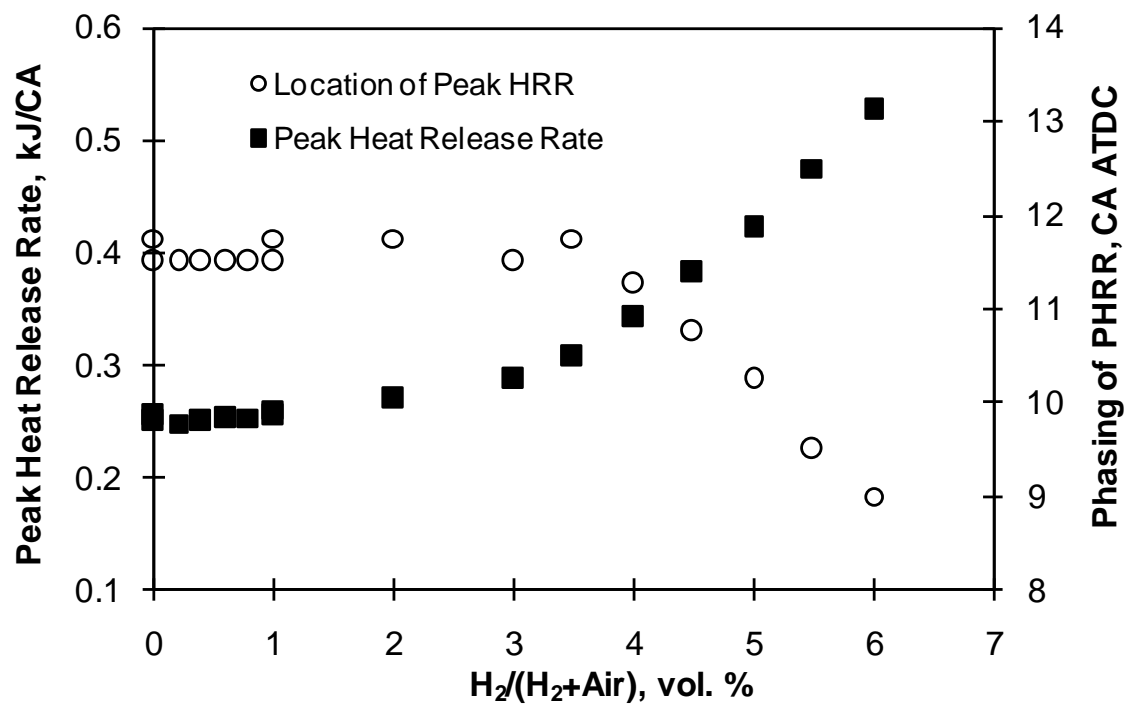

Figure 52 Effect of $\mathrm{H}_{2}$ Addition on Peak Heat Release Rate and Its Phasing, $\mathrm{N}=1200$ RPM, 70\% Load

Figure 53 to Figure 57 shows the effect of $\mathrm{H}_{2}$ addition on cylinder pressure, intake pressure, heat release process, and the peak heat release rate when operated at $30 \%$ load. As shown in Figure 53 and Figure 54, the addition of $\mathrm{H}_{2}$ at $30 \%$ load increased slightly the cylinder pressure and the intake pressure after combustion was initiated. However, its effect on the peak cylinder pressure and their phasing was relatively small as shown in Figure 55. Similar to that of peak cylinder pressure, the addition of $\mathrm{H}_{2}$ at $30 \%$ load slightly increased the peak heat release rate. However, its effect on the phasing of the peak heat release rate was small. As shown in Figure 56 and Figure 57, the addition of $\mathrm{H}_{2}$ at 30\% load enhanced the premixed combustion and retarded its phasing, due to the retarded injection timing. In comparison, its addition was shown slightly inhibit the diffusion combustion. Compared to high load operation, the peak heat release rate was obtained at the premixed combustion stage when operated at $30 \%$ load as shown in Figure 56. 


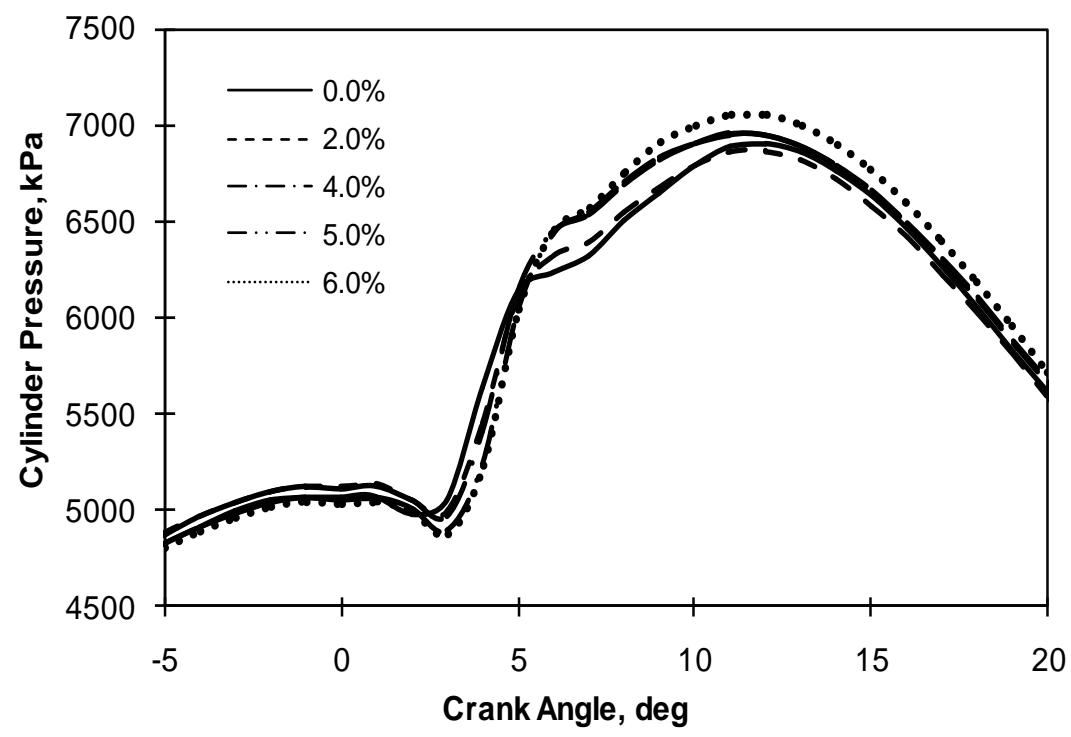

Figure 53 Effect of $\mathrm{H}_{2}$ Addition on Cylinder Pressure, N=1200 RPM, 30\% Load

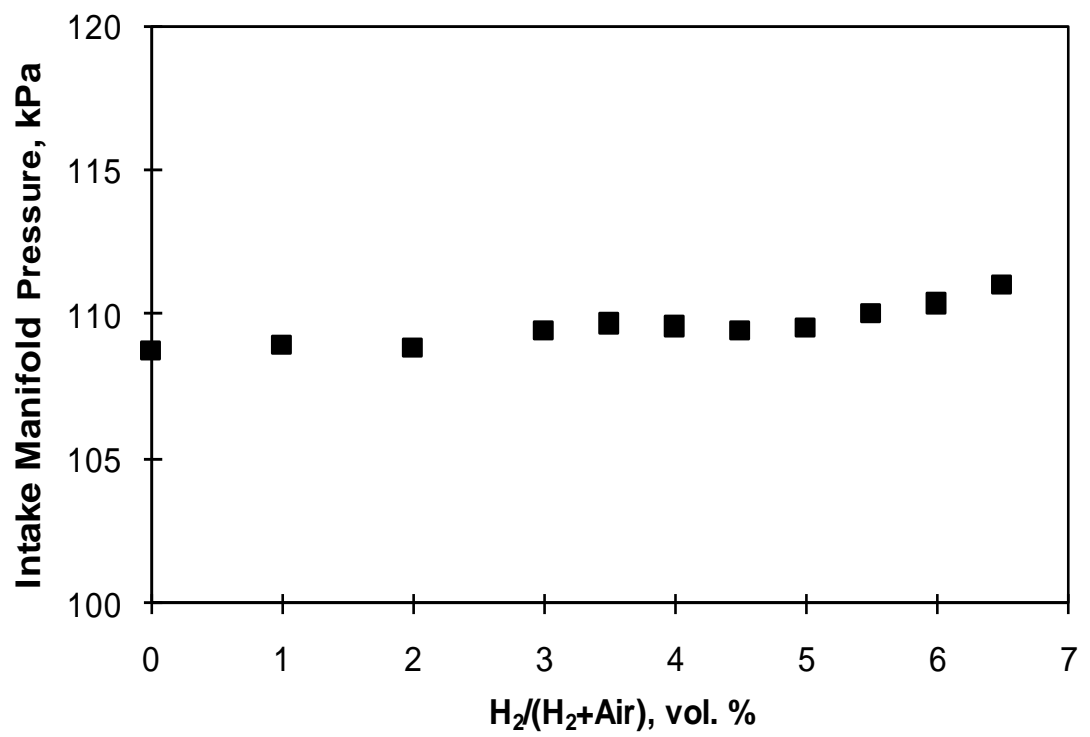

Figure 54 Effect of $\mathrm{H}_{2}$ Addition on Intake Manifold Pressure, N=1200 RPM, 30\% Load 


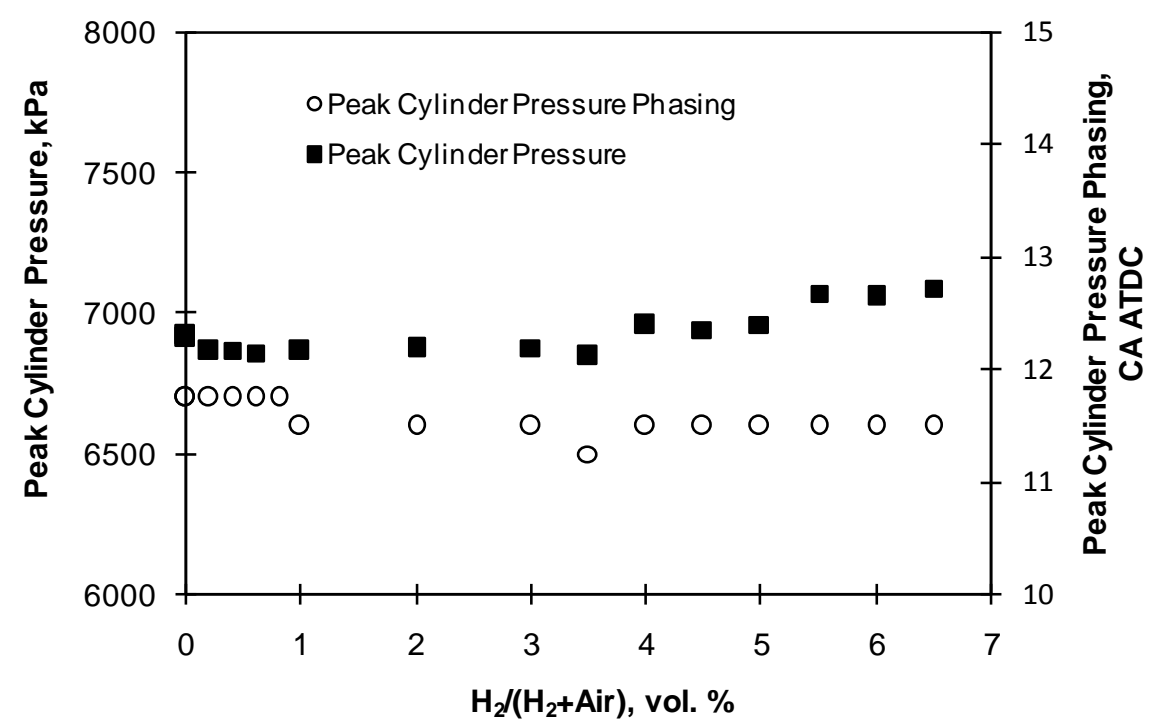

Figure 55 Effect of $\mathrm{H}_{2}$ Addition on Peak Cylinder Pressure and Its Phasing, $\mathrm{N}=1200$ RPM, 30\% Load

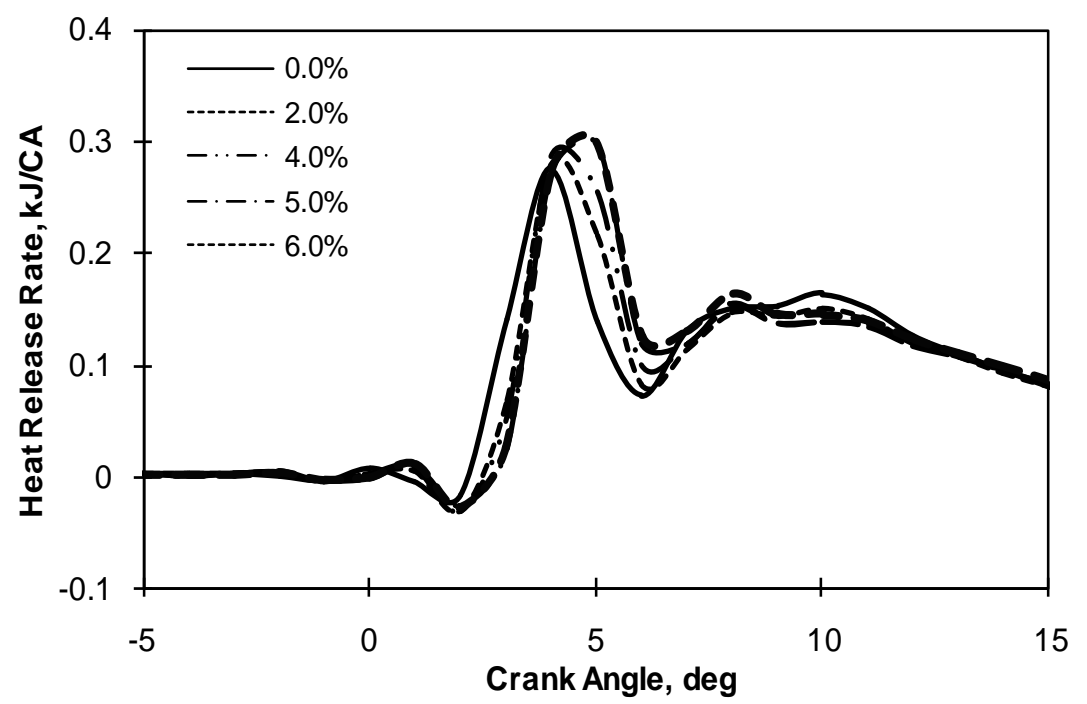

Figure 56 Effect of $\mathrm{H}_{2}$ Addition on Heat Release Rate, N=1200 RPM, 30\% Load 


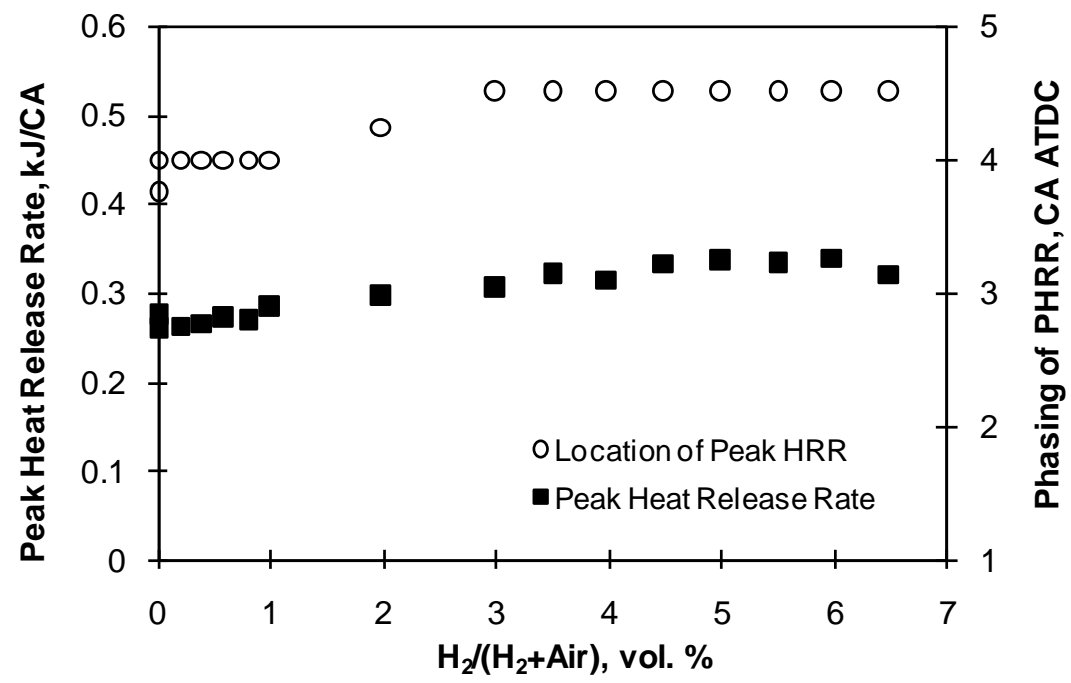

Figure 57 Effect of $\mathrm{H}_{2}$ Addition on Peak Heat Release Rate and Its Phasing, $\mathrm{N}=1200$ RPM, 30\% Load

Figure 58 to Figure 62 shows the effect of $\mathrm{H}_{2}$ addition on the cylinder pressure, and heat release process when operated at 15\% load. As shown in Figure 58 and Figure 59 , the addition of $\mathrm{H}_{2}$ at $15 \%$ load reduced substantially the cylinder pressure with negligible effect on the phasing when the peak cylinder pressure was observed. This was mainly due to the deteriorated premixed combustion process as shown in Figure 60. In comparison, the diffusion combustion process was further retarded with enhanced heat release rate at the late stage of diffusion combustion. Similar to $30 \%$ load operation, the peak heat release rate was observed at the premixed combustion stage. As shown in Figure 61, the addition of a small amount of $\mathrm{H}_{2}$ (less that 2\%) had negligible effect on the peak heat release rate and its phasing. Increasing the amount of $\mathrm{H}_{2}$ beyond $3 \%$ was shown to substantially reduce the peak heat release rate with negligible effect on the phasing when peak heat release rate was observed. The reduction in the peak heat release rate may be due to the reduction in diesel flow rate. As shown in Figure 62, the peak heat 
release rate was found to decrease with the reduced diesel flow following the addition of the increasing amount of $\mathrm{H}_{2}$.

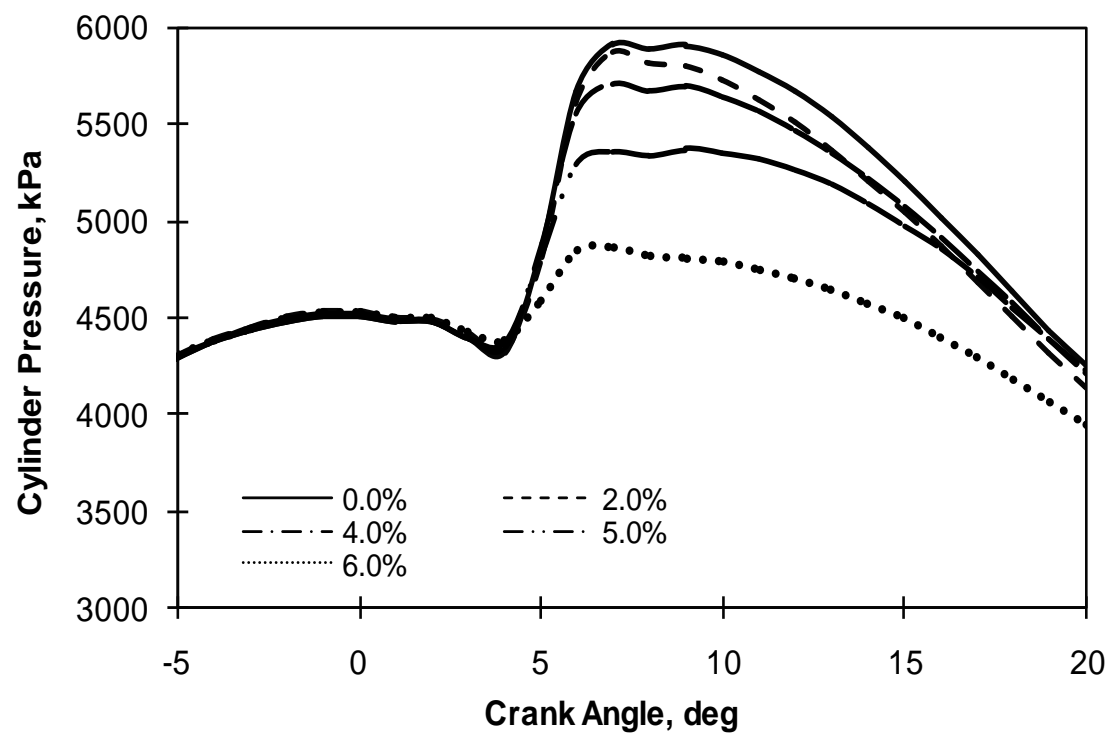

Figure 58 Effect of $\mathrm{H}_{2}$ Addition on Cylinder Pressure, N=1200 RPM, 15\% Load

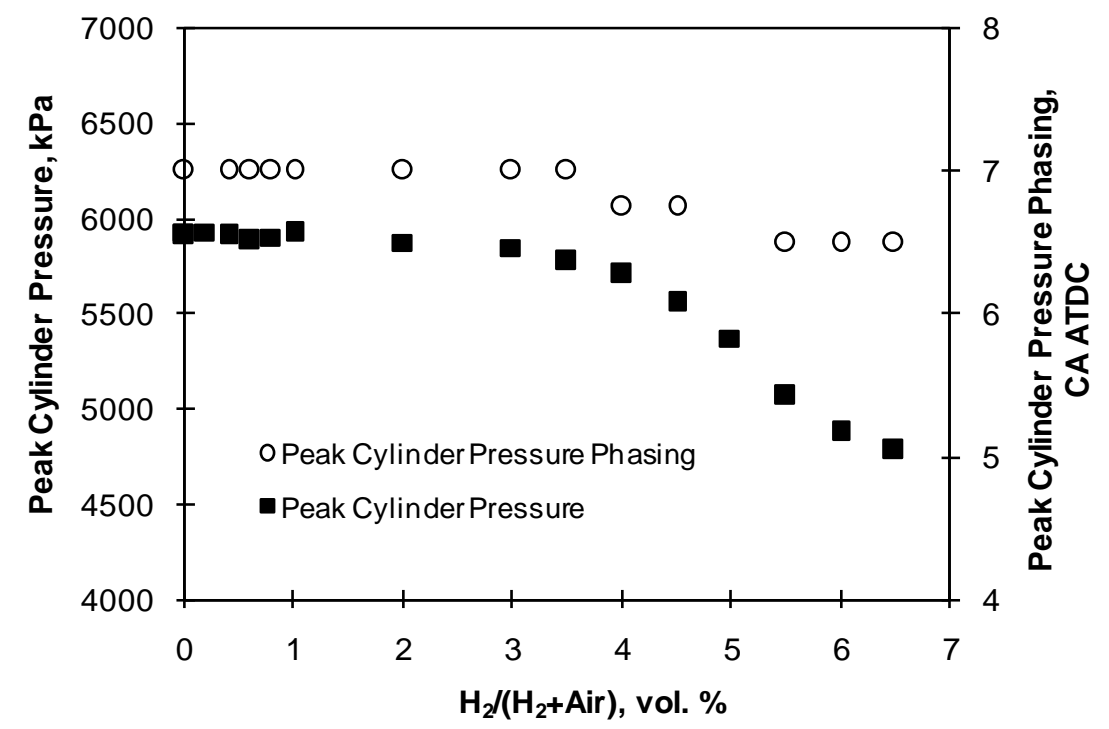

Figure 59 Effect of $\mathrm{H}_{2}$ Addition on Peak Cylinder Pressure and Its Phasing, N=1200 RPM, $15 \%$ Load 


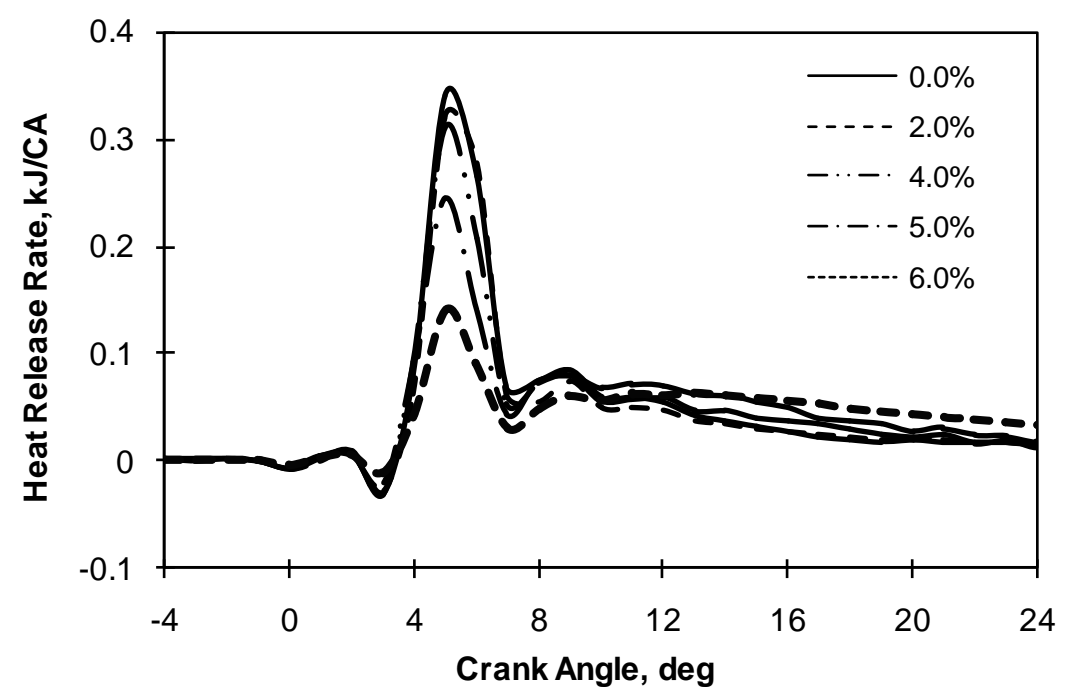

Figure 60 Effect of $\mathrm{H}_{2}$ Addition on Heat Release Rate, N=1200 RPM, 15\% Load

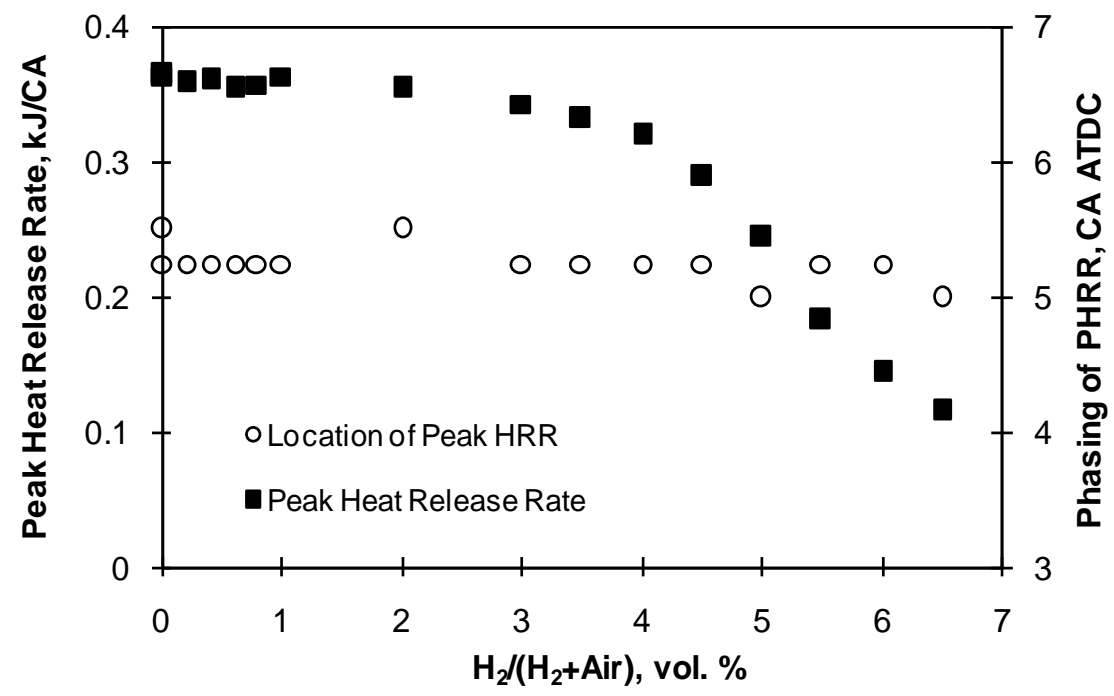

Figure 61 Effect of $\mathrm{H}_{2}$ Addition on Peak Heat Release Rate and Its Phasing, N=1200 RPM, 15\% Load 


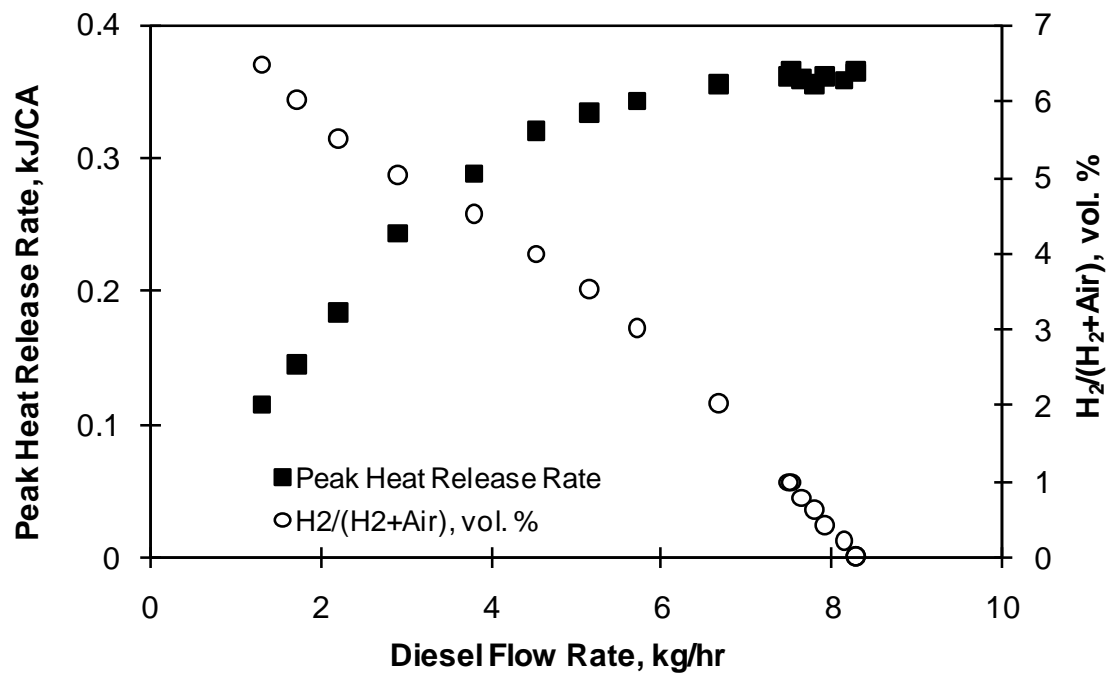

Figure 62 Effect of Diesel Flow Rate on Peak Heat Release Rate of $\mathrm{H}_{2}$-Diesel Dual Fuel Engine, N=1200 RPM, 15\% Load

Table 16 shows the effect of $\mathrm{H}_{2}$ addition on the SOI, SOC and ignition delay at 15\% load operation. The addition of $\mathrm{H}_{2}$ had negligible effect on the SOI and also the ignition delay.

Table 16 Effect of $\mathrm{H}_{2}$ Addition on the SOI, SOC, and Ignition Delay When Operated at 1200 RPM, 15\% Load

\begin{tabular}{|c|c|c|c|}
\hline $\begin{array}{c}\mathbf{H}_{\mathbf{2}} /\left(\mathbf{H}_{\mathbf{2}}+\text { Air), }\right. \\
\text { vol. } \%\end{array}$ & SOI, CA ATDC & SOC, CA ATDC & Ignition Delay, CA \\
\hline 0 & 0.0 & 3.82 & 3.82 \\
\hline 2 & 0.1 & 3.92 & 3.82 \\
\hline 4 & 0.0 & 3.75 & 3.75 \\
\hline 5 & -0.1 & 3.72 & 3.82 \\
\hline 6 & 0.0 & 4.08 & 4.08 \\
\hline
\end{tabular}

Figure 63 compared the effect of engine load and the addition of $\mathrm{H}_{2}$ on the changes of the peak heat release rate. The significant effect of $\mathrm{H}_{2}$ addition on peak heat release rate was observed when the amount of $\mathrm{H}_{2}$ addition was beyond $4 \%$. When 
operated at $70 \%$ load, the addition of $\mathrm{H}_{2}$ beyond $4 \%$ substantially increased the peak heat release rate, which was due to the development of the $\mathrm{H}_{2}$ turbulent flames. When operated at $15 \%$ load, the addition of $\mathrm{H}_{2}$ beyond $4 \%$ reduced the peak heat release rate due mainly to the reduction of diesel fuel flow rate, which resulted in deteriorated premixed combustion. When operated at $30 \%$ load, the effect of $\mathrm{H}_{2}$ addition on peak heat release rate was small.

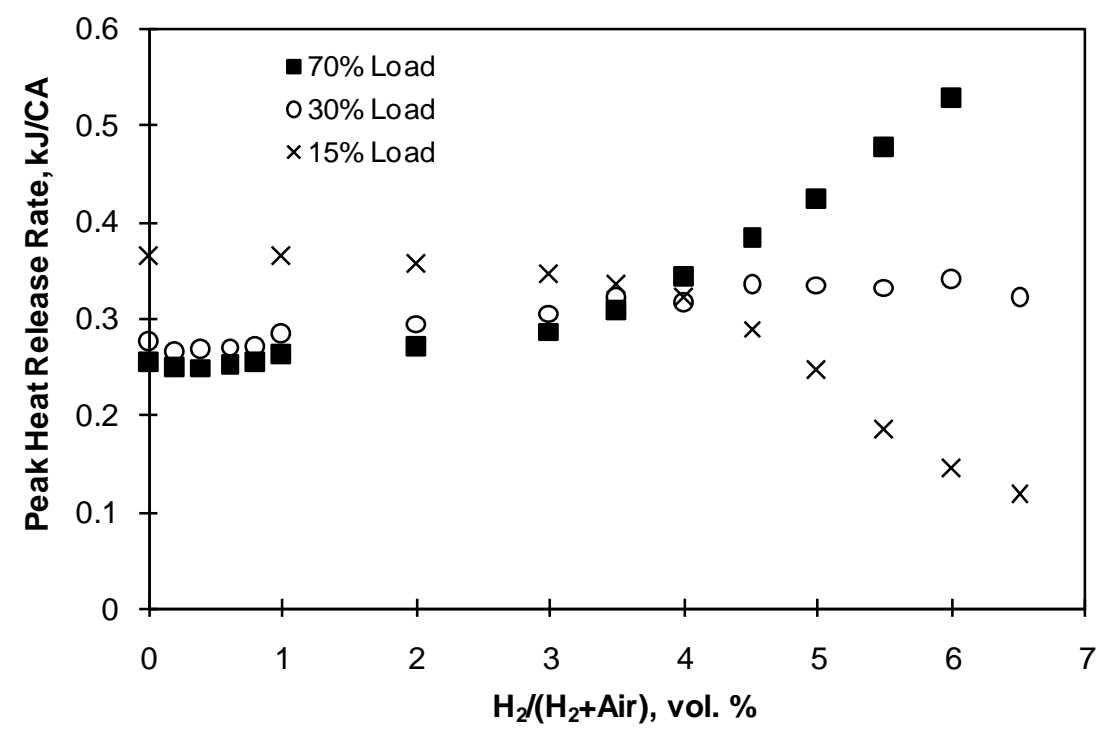

Figure 63 Effect of $\mathrm{H}_{2}$ Addition and Engine Load on the Peak Heat Release Rate, $\mathrm{N}=1200$ RPM, 15, 30, and 70\% Load

\subsection{Summary}

The effect of the addition of $\mathrm{H}_{2}$, engine load, and engine speed on performance, combustion, and exhaust emissions of a 1999 Cummins ISM370ESP diesel engine has been experimentally investigated without modifying the engine control and fuel injection strategies. Following is a brief summary based on the limited results obtained in this research: 
- The addition of $\mathrm{H}_{2}$ at medium to high load (30-70\%) substantially increased the emissions of $\mathrm{NO}_{\mathrm{x}}$. When operated at low load (10-15\%), the addition of a small amount of $\mathrm{H}_{2}(<3 \%)$ had negligible effect on $\mathrm{NO}_{\mathrm{x}}$ emissions. However, the addition of a relatively large amount of $\mathrm{H}_{2}$ (beyond 3-4\% depending on load) at this very narrow low load operational region reduced substantially the emissions of $\mathrm{NO}_{\mathrm{x}}$. When measured using the 13-mode ESC, the addition of 2 and $4 \% \mathrm{H}_{2}$ increased the emissions of $\mathrm{NO}_{\mathrm{x}}$ by 5.28 and $15.5 \%$, respectively.

- The addition of $\mathrm{H}_{2}$ reduced substantially the PM emissions measured under constant load. When operated at $10-70 \%$ load, the addition of $\mathrm{H}_{2}(0-6.5 \%)$ reduced the PM emissions by up to 40 to $65 \%$. When measured using the $13-$ mode emission cycle, the addition of $2 \% \mathrm{H}_{2}$ increased PM emissions from 0.032 to $0.037 \mathrm{~g} / \mathrm{bhp}-\mathrm{hr}(+15.6 \%)$. In comparison, the PM emission obtained at $4 \% \mathrm{H}_{2}$ reduced to $0.029 \mathrm{~g} / \mathrm{bhp}-\mathrm{hr}(-9.4 \%)$.

- The addition of $\mathrm{H}_{2}$ under constant load reduced substantially the emissions of $\mathrm{CO}$ with the exception of $70 \%$ load. When operated at $70 \%$ load, the addition of relatively large amount of $\mathrm{H}_{2}$ (4-6\%) slightly increased the emissions of CO. When measured using the 13-mode ESC, the addition of $2 \% \mathrm{H}_{2}$ increased from 0.25 to $0.26 \mathrm{~g} / \mathrm{bhp}-\mathrm{hr}(+4.0 \%)$ compared to pure diesel operation. In comparison, the addition of $4 \% \mathrm{H}_{2}$ reduced $\mathrm{CO}$ emissions from 0.25 to $0.21 \mathrm{~g} / \mathrm{bhp}-\mathrm{hr}$ (-16.0\%)

- The addition of $\mathrm{H}_{2}$ at medium to high load (30-70\%) had a negligible effect on the emissions of HC. In comparison, the addition of $\mathrm{H}_{2}$ at low load (10-20\%) slightly increased the emissions of HC. When measured using the 13-mode ESC, the 
addition of $2 \% \mathrm{H}_{2}$ had negligible effect on $\mathrm{HC}$ emissions. In comparison, the addition of $4 \% \mathrm{H}_{2}$ increased slightly from 0.12 to $0.13 \mathrm{~g} / \mathrm{bhp}-\mathrm{hr}$ (+8.3\%).

- The addition of $\mathrm{H}_{2}$ reduced substantially the emissions of $\mathrm{CO}_{2}$. When measured using 13-mode ESC, the addition of 2 and $4 \% \mathrm{H}_{2}$ substantially reduced the emissions of $\mathrm{CO}_{2}$ from 474.7 to $416.7(-12.2 \%)$ and 347.9 g/bhp-hr (-26.7\%), respectively.

- The addition of a small amount of $\mathrm{H}_{2}(<1 \%)$ at 10 to $70 \%$ load deteriorated the BTE. However, the addition of $\mathrm{H}_{2}$ (3-6.5\%) at 15 to $70 \%$ load improved the brake thermal efficiency. The addition of $6 \% \mathrm{H}_{2}$ improved the BTE by $8.72-4.56 \%$ (relative) when operated at $15-70 \%$ load.

- When operated at high load, the addition of $\mathrm{H}_{2}$ mainly affected the diffusion combustion process. In comparison, the addition of $\mathrm{H}_{2}$ at low load mainly affected the premixed combustion. With the addition of $\mathrm{H}_{2}$ at large amounts under high load, a featured three-stage combustion process of $\mathrm{H}_{2}$-diesel dual fuel engine was observed.

- The addition of a large amount of $\mathrm{H}_{2}(6 \%)$ at $70 \%$ load increased the peak cylinder pressure and peak heat release rate from 107.2 to 120.9 bar and 0.25 to $0.53 \mathrm{~kJ} / \mathrm{CA}$, respectively. In comparison with the addition of a large amount of $\mathrm{H}_{2}$ (6\%) at 15\% load decreased the peak cylinder pressure and peak heat release rate from 59.2 to 48.6 bar and 0.34 to $0.14 \mathrm{~kJ} / \mathrm{CA}$, respectively. 


\section{INVESTIGATION OF EMISSIONS AND COMBUSTION OF A 2004 MACK MP7 355E ENGINE SUPPLEMENTED WITH $\mathrm{H}_{2}$}

\subsection{Test Matrix}

The test matrix for the 2004 Mack MP7 355E was similar to that of the 1999 Cummins ISM370ESP engine. The details of the engine testing set point for 13-Mode ESC, constant load, and constant diesel fuel flow are shown in Table 17, Table 18, and Table 19.

Table 17 Set Points for 13-Mode ESC, 2004 Mack MP7 355E

\begin{tabular}{|c|c|c|c|}
\hline Mode & Speed & Torque, ft-lb & Weighting Factor, \% \\
\hline 1 & 700 & 0 & 15 \\
\hline 2 & 1225 & 1399 & 10 \\
\hline 3 & 1501 & 640 & 10 \\
\hline 4 & 1501 & 959 & 5 \\
\hline 5 & 1225 & 700 & 5 \\
\hline 6 & 1225 & 1049 & 5 \\
\hline 7 & 1225 & 350 & 10 \\
\hline 8 & 1501 & 1279 & 8 \\
\hline 9 & 1501 & 320 & 5 \\
\hline 10 & 1776 & 1091 & 5 \\
\hline 11 & 1776 & 273 & 518 \\
\hline 12 & 1776 & 546 & 5 \\
\hline 13 & 1776 & & 5 \\
\hline
\end{tabular}


Table 18 Constant Load Test Matrix for 2004 Mack MP7 355E, N=1200 RPM

\begin{tabular}{|c|c|}
\hline Load, $\%$ & $\mathbf{H}_{2} /\left(\mathbf{H}_{2}+\right.$ Air $)$, vol. $\%$ \\
\hline 10 & $0.0,0.2,0.4,0.6,0.8,1.0,2.0,3.0,4.0,4.5,5.0,5.5,6.0,6.5,7.0$, and 7.5 \\
\hline 15 & $0.0,1.0,2.0,3.0,3.5,4.0,4.5,5.0,5.5,6.0,6.5$, and 7.0 \\
\hline 20 & $0.0,0.2,0.4,0.6,0.8,1.0,2.0,3.0,4.0,4.5,5.0,5.5,6.0,6.5,7.0$, and 7.5 \\
\hline 30 & $0.0,1.0,2.0,3.0,4.0,4.5,5.0,5.5,6.0$, and 7.0 \\
\hline 50 & $0.0,0.2,0.4,0.6,0.8,1.0,2.0,3.0,3.5,4.0,4.5,5.0,5.5,6.0$, and 6.5 \\
\hline 70 & $0.0,0.2,0.4,0.6,0.8,1.0,2.0,2.5,3.0,3.5,4.0,4.5,5.0$, and 6.0 \\
\hline 100 & $0.0,2.0(1225 \mathrm{RPM}), 3.0,4.0(1225 \mathrm{RPM})$, and 5.0 \\
\hline
\end{tabular}

Table 19 Test Matrix for Constant Diesel Fuel Flow Rate, 2004 Mack MP7 355E

\begin{tabular}{|c|c|}
\hline Diesel Flow Rate, $\mathbf{k g} / \mathbf{h r}$ & $\mathbf{H}_{2} /\left(\mathbf{H}_{2}+\right.$ Air $), \mathbf{v o l .} \%$ \\
\hline 16.44 & $0.0,1.0,2.0,2.5,3.0,4.0,4.5,5.0,5.5,6.0,6.5$, and 7.0 \\
\hline 25.05 & $0.0,1.0,2.0,2.5,3.0,3.5,4.0,4.5,5.0$, and 5.5 \\
\hline
\end{tabular}

Figure 64 shows the effect of $\mathrm{H}_{2}$ addition on the equivalent ratio of diesel fuel. The equivalent ratio at every load decreased linearly with the addition of $\mathrm{H}_{2}$ up to $7.5 \%$ indicating that the diesel fuel flow reduced. The lowest diesel fuel equivalent ratio was 0.1 at $10 \%$ load with $7.5 \% \mathrm{H}_{2}$ addition. The total equivalent ratio of $\mathrm{H}_{2}$ and diesel fuel was shown in Figure 65. The addition of up to $3 \% \mathrm{H}_{2}$ slightly increased the total equivalence ratio. However, the addition of $\mathrm{H}_{2}$ beyond $3 \%$ decreased slowly towards the baseline total equivalent ratio. The effect of $\mathrm{H}_{2}$ addition on total equivalent ratio for 30$100 \%$ load showed negligible effect up to $3 \% \mathrm{H}_{2}$ addition. However, the addition of $\mathrm{H}_{2}$ beyond 3\% slightly increased the total equivalence ratio. 


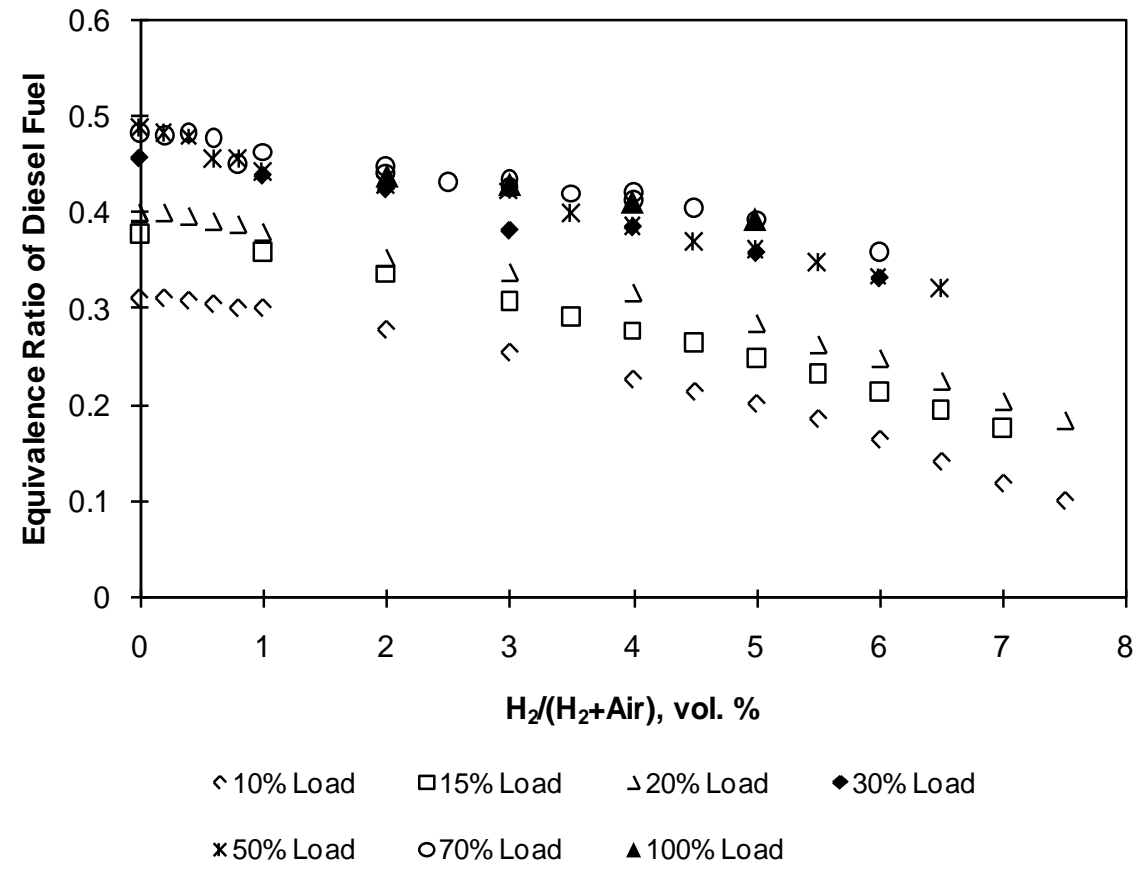

Figure 64 Effect of $\mathrm{H}_{2}$ Addition on Equivalence Ratio of the Diesel Fuels, 2004 Mack MP7 355E, N=1200 RPM, 10-100\% Load

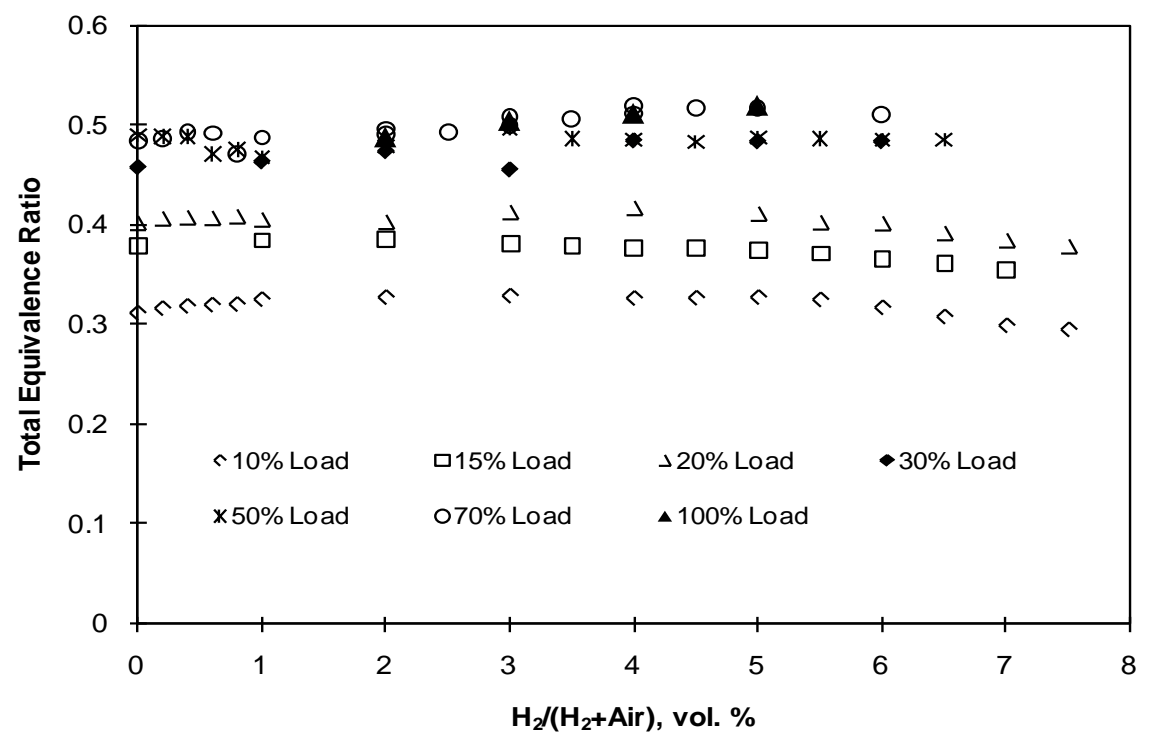

Figure 65 Effect of $\mathrm{H}_{2}$ Addition on Total Equivalence Ratio Including That of $\mathrm{H}_{2}$ and Diesel, 2004 Mack MP7 355E, N=1200 RPM, 10-100\% Load 


\subsection{3-Mode ESC}

The effect of $\mathrm{H}_{2}$ addition on regulated emissions was measured using the 13-mode ESC. As shown in Table 20, the addition of 2 and 4\% $\mathrm{H}_{2}$ into this 2004 Mack MP7 355E diesel engine reduced PM emissions from 0.040 to 0.033 and $0.029 \mathrm{~g} / \mathrm{bhp}-\mathrm{hr}$, respectively. Compared to pure diesel operation, the PM emissions were reduced by 17.5 and $27.5 \%$, respectively.

Table 20 Effect of $\mathrm{H}_{2}$ Addition on Exhaust Emissions Measured using 13-Mode ESC, g/bhp-hr

\begin{tabular}{|c|c|c|c|c|c|}
\hline $\mathbf{H}_{\mathbf{2}} /\left(\mathbf{H}_{\mathbf{2}}+\right.$ Air), vol. $\%$ & $\mathbf{P M}$ & $\mathbf{N O}_{\mathbf{x}}$ & $\mathbf{C O}$ & $\mathbf{H C}$ & $\mathbf{C O}_{\mathbf{2}}$ \\
\hline 0 & 0.040 & 2.02 & 0.76 & 0.072 & 497.0 \\
\hline 2 & 0.033 & 2.03 & 0.74 & 0.078 & 431.0 \\
\hline 4 & 0.029 & 2.10 & 0.82 & 0.072 & 360.2 \\
\hline
\end{tabular}

As shown in Table 20, the addition of $2 \% \mathrm{H}_{2}$ had negligible effect on $\mathrm{NO}_{\mathrm{x}}$ emissions while the addition of $4 \% \mathrm{H}_{2}$ slightly increased the $\mathrm{NO}_{\mathrm{x}}$ emissions from 2.02 to $2.10 \mathrm{~g} / \mathrm{bhp}-\mathrm{hr}$. Compared to pure diesel operation, the emissions of $\mathrm{NO}_{\mathrm{x}}$ were increased by $4.0 \%$. As shown in Table 21, the addition of 2 and $4 \% \mathrm{H}_{2}$ into the 1999 Cummins ISM370ESP engine increased $\mathrm{NO}_{\mathrm{x}}$ emissions by 5.3 and $15.5 \%$, respectively. It is evident that the addition of $\mathrm{H}_{2}$ into the 2004 Mack MP7 355E engine has less effect on $\mathrm{NO}_{\mathrm{x}}$ emissions compared to that of the 1999 Cummins ISM370ESP diesel engine. 
Table 21 Effect of $\mathrm{H}_{2}$ Addition on $\mathrm{NO}_{\mathrm{x}}$ Emissions of a 2004 Mack MP7 355E and a 1999 Cummins ISM370ESP Engine Measured Using 13-Mode ESC, g/bhp-hr

\begin{tabular}{|c|c|c|c|c|}
\hline \multirow{2}{*}{$\begin{array}{c}\mathbf{H}_{2} /\left(\mathbf{H}_{2}+\text { Air }\right), \\
\text { vol. } \%\end{array}$} & \multicolumn{2}{|c|}{2004 Mack MP7 355E } & \multicolumn{2}{|c|}{1999 Cummins ISM370ESP } \\
\hline & $\begin{array}{c}\text { NO }_{\mathrm{x}} \text { Emissions, } \\
\text { g/bhp-hr }\end{array}$ & $\begin{array}{c}\text { Changes, } \\
\%\end{array}$ & $\begin{array}{c}\text { NO }_{x} \text { Emissions, } \\
\text { g/bhp-hr }\end{array}$ & $\begin{array}{c}\text { Changes, } \\
\%\end{array}$ \\
\hline 0 & 2.02 & - & 3.41 & - \\
\hline 2 & 2.03 & +0.5 & 3.59 & +5.3 \\
\hline 4 & 2.10 & +4.0 & 3.94 & +15.5 \\
\hline
\end{tabular}

The detailed effect of the addition of $\mathrm{H}_{2}$ on $\mathrm{NO}_{\mathrm{x}}$ emissions of each mode is shown in Figure 66. The addition of $2 \% \mathrm{H}_{2}$ increased $\mathrm{NO}_{\mathrm{x}}$ emissions at mode 5, 6, 7, 9, 10, 11, and 13. Compared to diesel operation, the addition of $4 \% \mathrm{H}_{2}$ increased the $\mathrm{NO}_{\mathrm{x}}$ emissions at mode $3,5,7,9,10$, and 11 .

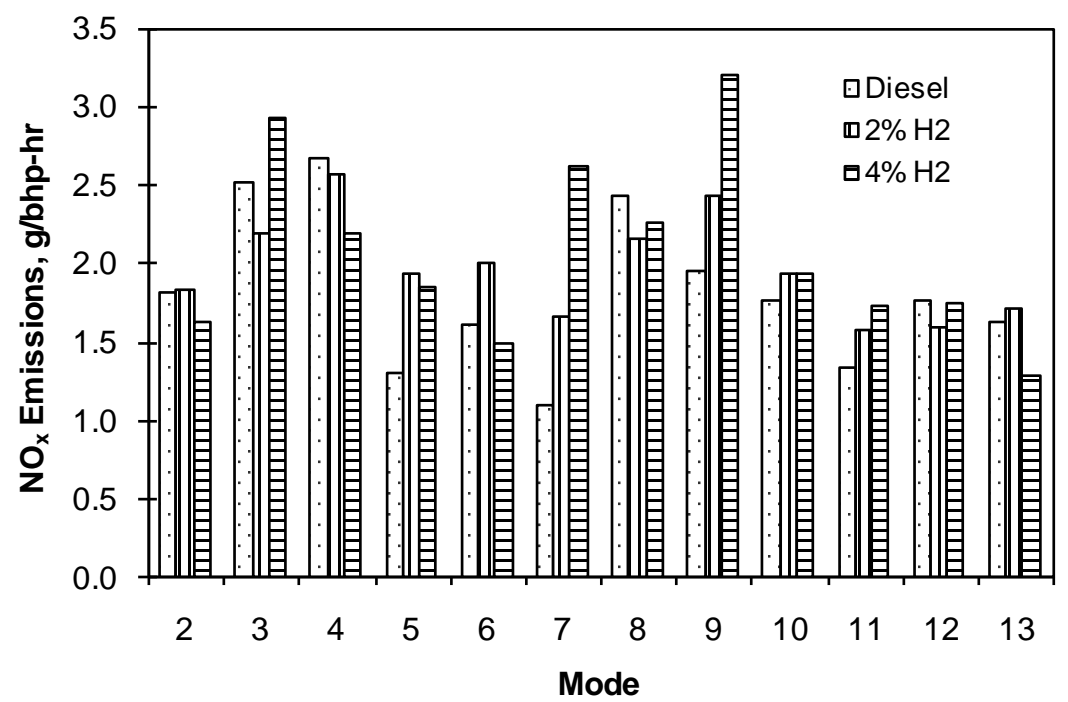

Figure 66 Effect of $\mathrm{H}_{2}$ Addition on $\mathrm{NO}_{\mathrm{x}}$ Emissions, 13-Mode ESC

As shown in Table 20, the addition of $2 \% \mathrm{H}_{2}$ reduced $\mathrm{CO}$ emissions from 0.76 to $0.74 \mathrm{~g} / \mathrm{bhp}-\mathrm{hr}(-2.6 \%)$. However, the addition of $4 \% \mathrm{H}_{2}$ increased the $\mathrm{CO}$ emissions from 0.76 to 0.82 g/bhp-hr (+7.9\%). As shown in Figure 67, the addition of 2 and $4 \% \mathrm{H}_{2}$ 
reduced the $\mathrm{CO}$ emissions at all modes with the exception of mode 2, 6, and 8 which were the high load operating conditions in 13-mode ESC.

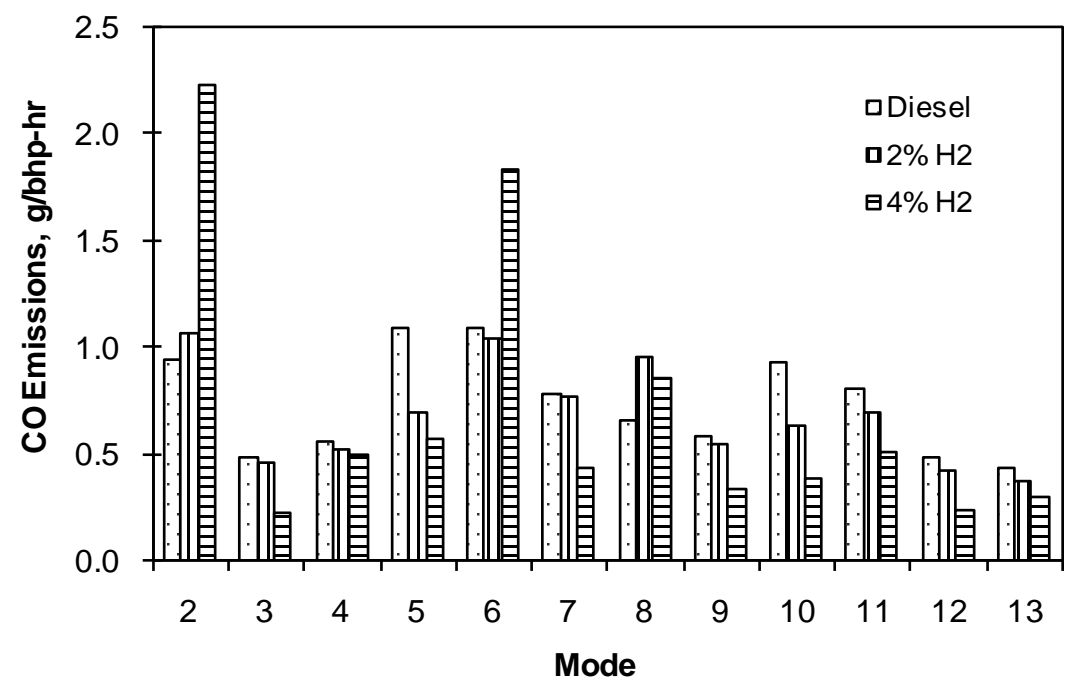

Figure 67 Effect of $\mathrm{H}_{2}$ Addition on CO Emissions, 13-Mode ESC

As shown in Table 20, the addition of $2 \% \mathrm{H}_{2}$ increased the emissions of $\mathrm{HC}$ from 0.072 to $0.078 \mathrm{~g} / \mathrm{bhp}-\mathrm{hr}(+8.3 \%)$. In comparison, the addition of $4 \% \mathrm{H}_{2}$ had negligible effect on $\mathrm{HC}$ emissions. As shown in Figure 68, the addition of $2 \% \mathrm{H}_{2}$ slightly increased the HC emissions at all modes with the exception of mode 2. However, the addition of $4 \% \mathrm{H}_{2}$ produced more $\mathrm{HC}$ at mode 11 but less or comparable $\mathrm{HC}$ emissions at other modes.

As shown in Table 20, the addition of 2 and $4 \% \mathrm{H}_{2}$ reduced the $\mathrm{CO}_{2}$ emissions from 497.0 to 431.0 (-13.3\%) and 360.2 g/bhp-hr (-27.5\%), respectively. The detailed effect of the addition of $\mathrm{H}_{2}$ on $\mathrm{CO}_{2}$ emissions can be found in Figure 69. The addition of 2 and $4 \%$ of $\mathrm{H}_{2}$ reduced the $\mathrm{CO}_{2}$ emissions observed at all modes. 


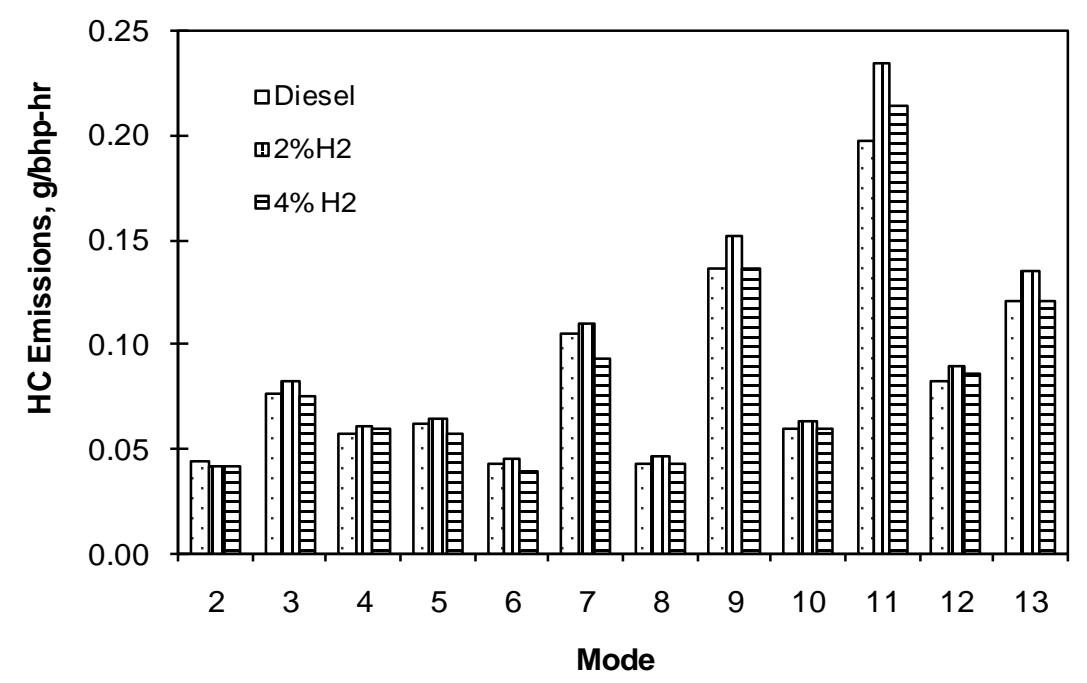

Figure 68 Effect of $\mathrm{H}_{2}$ Addition on HC Emissions, 13-Mode ESC

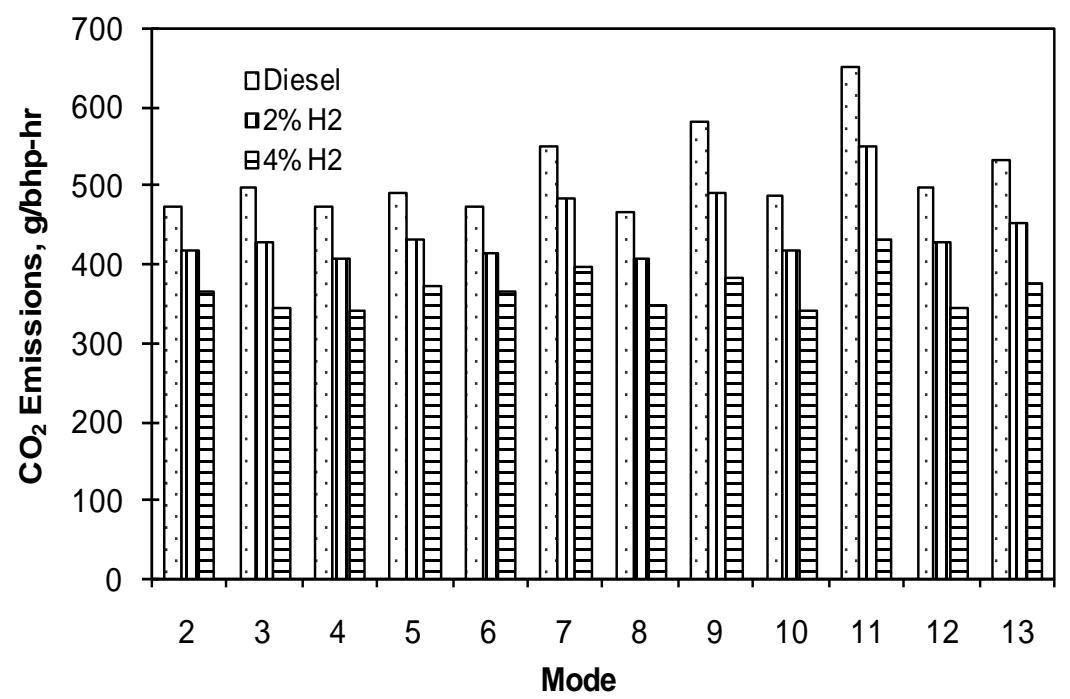

Figure 69 Effect of $\mathrm{H}_{2}$ Addition on $\mathrm{CO}_{2}$ Emissions, 13-Mode ESC

\subsection{Effect of $\mathrm{H}_{2}$ Addition and Engine Load on Exhaust Emissions 5.3.1 Effect of $\mathrm{H}_{2}$ Addition on the Emissions of $\mathrm{NO}_{\mathrm{x}}$, $\mathrm{NO}$, and $\mathrm{NO}_{2}$}

The effect of $\mathrm{H}_{2}$ addition on the $\mathrm{NO}_{\mathrm{x}}$ emissions was examined when operated under $10-100 \%$ load. As shown in Figure 70 , the addition of a small amount of $\mathrm{H}_{2}$ at $10 \%$ load reduced slightly the $\mathrm{NO}_{\mathrm{x}}$ emissions until the concentration of $\mathrm{H}_{2}$ reached $4 \%$ in the 
intake mixture. Further increasing the addition of $\mathrm{H}_{2}$ beyond 4\% reduced substantially the emissions of $\mathrm{NO}_{\mathrm{x}}$. The addition of $\mathrm{H}_{2}$ at $15 \%$ load increased slightly the emissions of $\mathrm{NO}_{\mathrm{x}}$. Further increasing the addition of $\mathrm{H}_{2}$ beyond $6 \%$ reduced the emissions of $\mathrm{NO}_{\mathrm{x}}$. The addition of $\mathrm{H}_{2}$ up to $5 \%$ at $20 \%$ load had mild effect on $\mathrm{NO}_{\mathrm{x}}$ emissions with exception of the addition of $\mathrm{H}_{2}$ at 3\%. Further increasing the addition of $\mathrm{H}_{2}$ beyond $5 \%$ slightly increased the emissions of $\mathrm{NO}_{\mathrm{x}}$.

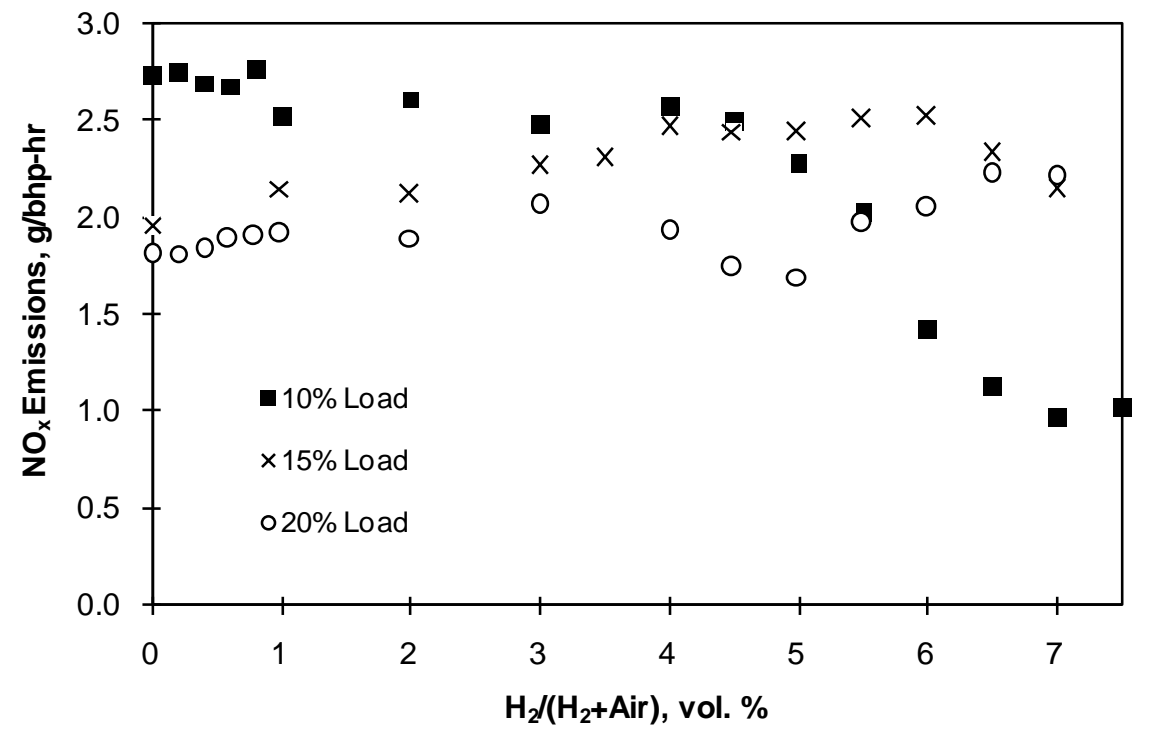

Figure 70 Effect of $\mathrm{H}_{2}$ Addition and Engine Load on $\mathrm{NO}_{\mathrm{x}}$ Emissions, N=1200 RPM, 10$20 \%$ Load

As shown in Figure 71, the addition of a small amount of $\mathrm{H}_{2}$ at $30 \%$ load slightly reduced the $\mathrm{NO}_{\mathrm{x}}$ emissions with its minimum value observed with the addition of $4.5 \%$ $\mathrm{H}_{2}$. Further increasing the amount of $\mathrm{H}_{2}$ added beyond $5 \%$ gradually increased the emissions of $\mathrm{NO}_{\mathrm{x}}$. The $\mathrm{NO}_{\mathrm{x}}$ emissions obtained with the addition of $6 \% \mathrm{H}_{2}$ was comparable to that of pure diesel operation. The high $\mathrm{NO}_{\mathrm{x}}$ emissions at $3 \% \mathrm{H}_{2}$ may be due to the unexpected operation of EGR and VGT, which will be discussed for 50\% load operation. 


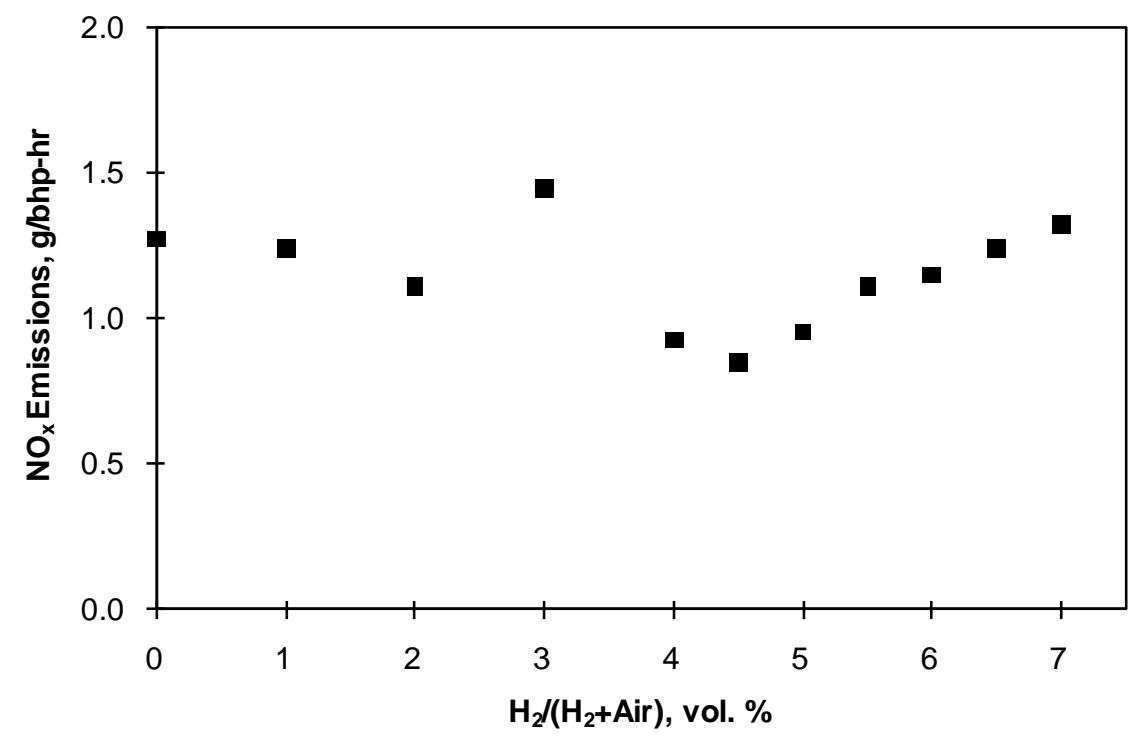

Figure 71 Effect of $\mathrm{H}_{2}$ Addition on $\mathrm{NO}_{\mathrm{x}}$ Emissions, N=1200 RPM, 30\% Load

As shown in Figure 72 for $50 \%$ load, the addition of 0.2 and $0.4 \% \mathrm{H}_{2}$ had negligible effect on the emissions of $\mathrm{NO}_{\mathrm{x}}$. However, a sudden increase in $\mathrm{NO}_{\mathrm{x}}$ emission was observed for the addition of $0.6,0.8,1$, and $2 \% \mathrm{H}_{2}$. This may be due to the sudden change in the VGT and EGR valve positions, which depended to a large extent on engine speed and the flow rate of diesel. As shown in Figure 73, the increased $\mathrm{NO}_{\mathrm{x}}$ emissions were accompanied with increased air flow, indicating the reduced EGR rate. If EGR system responded properly, the addition of a small amount of $\mathrm{H}_{2}$ should have negligible effect on $\mathrm{NO}_{\mathrm{x}}$ emissions. At the same time, the position of VGT may also has changed, which might affect the $\mathrm{NO}_{\mathrm{x}}$ emissions. 


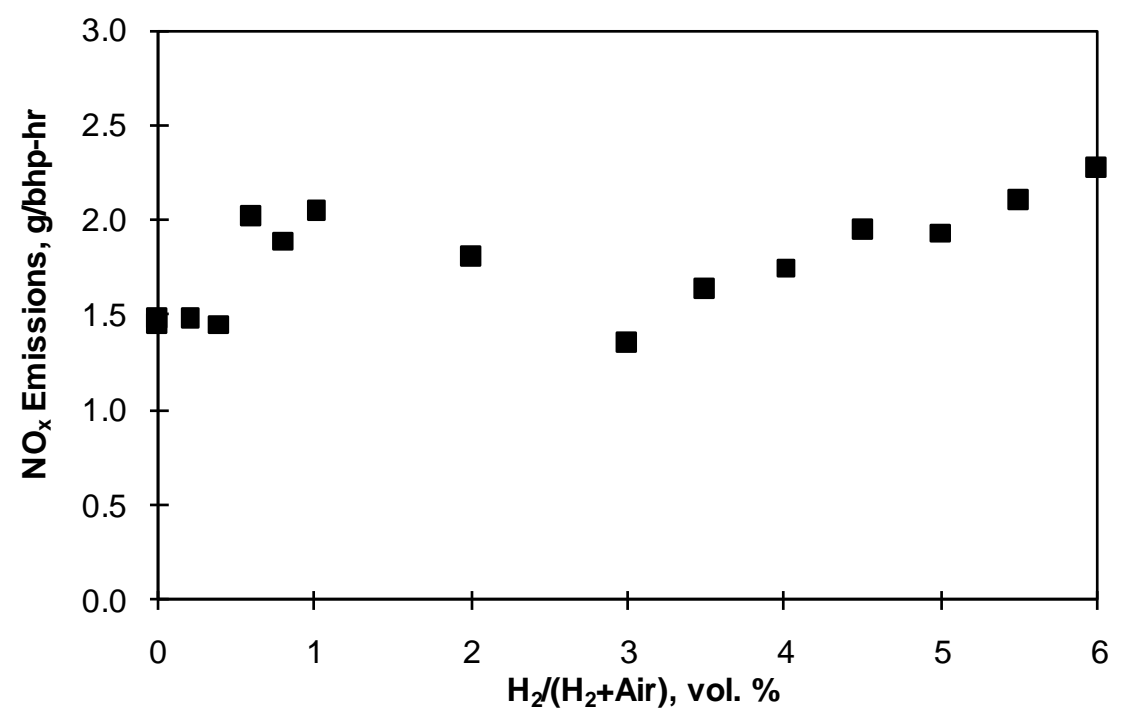

Figure 72 Effect of $\mathrm{H}_{2}$ Addition on $\mathrm{NO}_{\mathrm{x}}$ Emissions, $\mathrm{N}=1200 \mathrm{RPM}$, 50\% Load

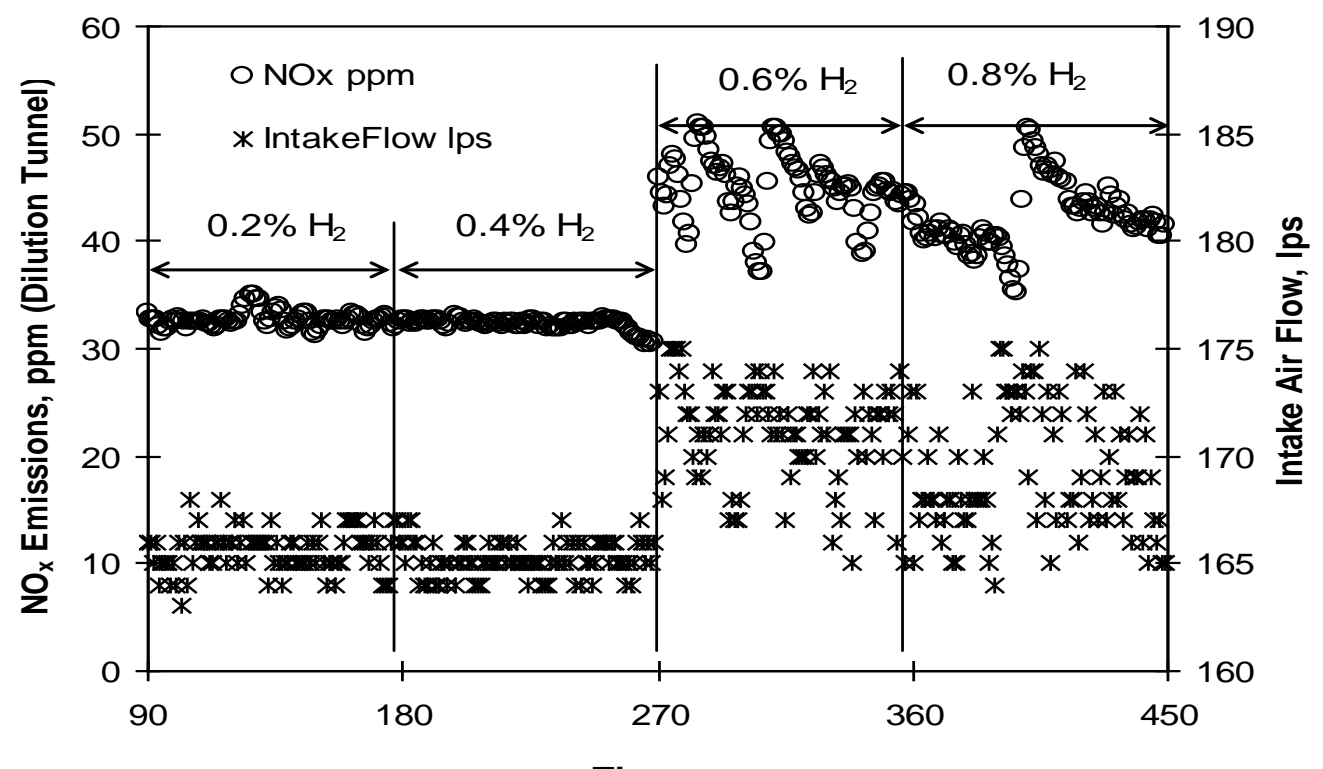

Time, s

Figure 73 Effect of $\mathrm{H}_{2}$ Addition on $\mathrm{NO}_{\mathrm{x}}$ Emissions and Intake Air Flow (liter per second (lps)) Measured Continuously, N=1200 RPM, 50\% Load

As shown in Figure 74, the addition of $\mathrm{H}_{2}$ slightly reduced the emissions of $\mathrm{NO}_{\mathrm{x}}$ with their minimum values observed with the addition of $4.5 \% \mathrm{H}_{2}$. Further increasing the addition of $\mathrm{H}_{2}$ beyond $4.5 \%$ started to increase the emissions of $\mathrm{NO}_{\mathrm{x}}$. As shown in Figure 75, the addition of $\mathrm{H}_{2}$ had negligible effect on $\mathrm{NO}_{\mathrm{x}}$ emissions for full load 
operation. Similar to that of the 1999 Cummins ISM370ESP engine, the addition of $\mathrm{H}_{2}$ was found to enhance the conversion of $\mathrm{NO}$ to $\mathrm{NO}_{2}$ as shown in Figure 76 .

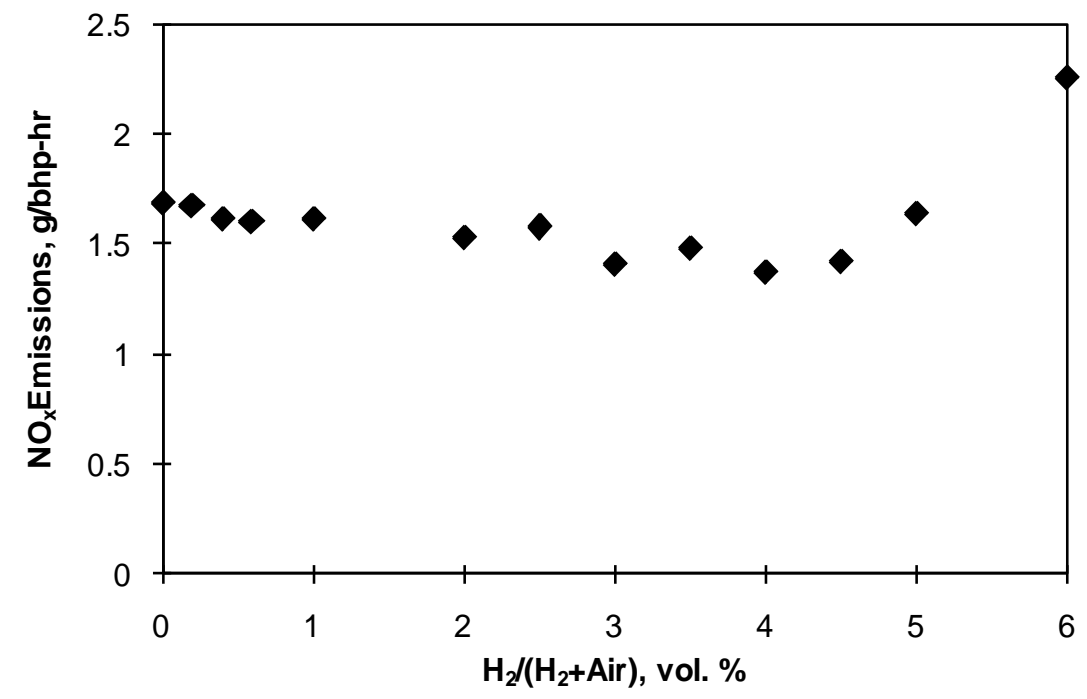

Figure 74 Effect of $\mathrm{H}_{2}$ Addition and Engine Load on $\mathrm{NO}_{\mathrm{x}}$ Emissions, $\mathrm{N}=1200 \mathrm{RPM}, 70 \%$ Load

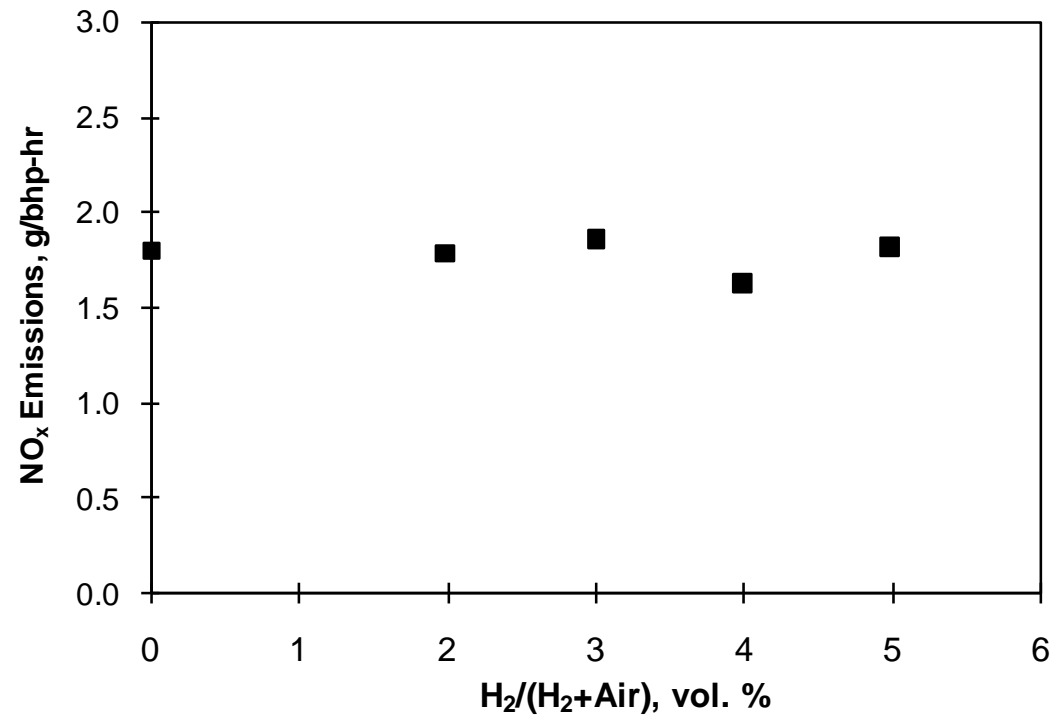

Figure 75 Effect of $\mathrm{H}_{2}$ Addition and Engine Load on $\mathrm{NO}_{\mathrm{x}}$ Emissions, N=1200 RPM, $100 \%$ Load 


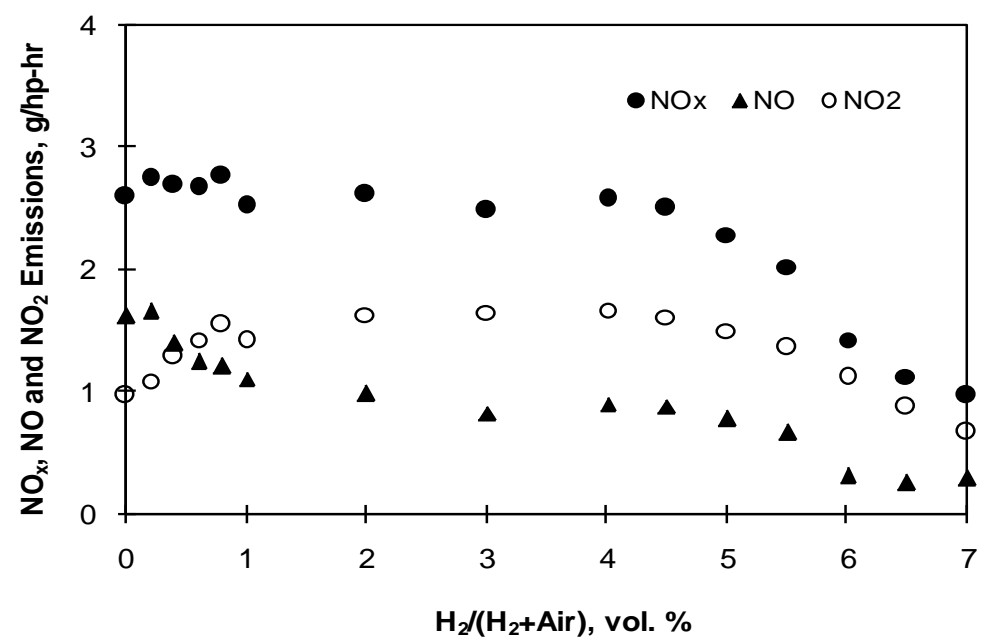

Figure 76 Effect of $\mathrm{H}_{2}$ Addition on the Emissions of $\mathrm{NO}_{x}, \mathrm{NO}$, and $\mathrm{NO}_{2}, \mathrm{~N}=1200 \mathrm{RPM}$, $10 \%$ Load

Figure 77 shows the effect of $\mathrm{H}_{2}$ addition on the emissions of $\mathrm{NO}_{\mathrm{x}}, \mathrm{NO}$, and $\mathrm{NO}_{2}$ at $70 \%$ load operation. The addition of $\mathrm{H}_{2}$ reduced the emissions of $\mathrm{NO}_{\mathrm{x}}$ and $\mathrm{NO}$ with their minimum values observed with the addition of $4.5 \% \mathrm{H}_{2}$. As shown in Figure 77, the addition of $\mathrm{H}_{2}$ enhanced the formation of $\mathrm{NO}_{2}$ with the maximum $\mathrm{NO}_{2}$ emissions observed with 1-2\% $\mathrm{H}_{2}$. Further increasing the addition of $\mathrm{H}_{2}$ started to reduce the $\mathrm{NO}_{2}$ emissions but still produces more $\mathrm{NO}_{2}$ than diesel operation.

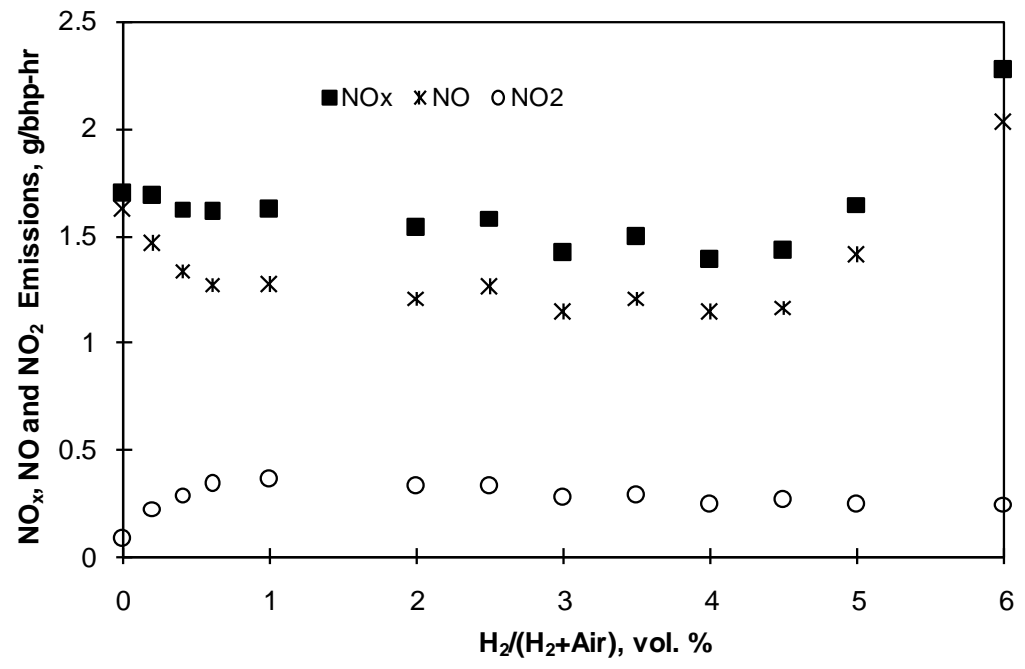

Figure 77 Effect of $\mathrm{H}_{2}$ Addition on the Emissions of $\mathrm{NO}_{\mathbf{x}}, \mathrm{NO}$, and $\mathrm{NO}_{2}, \mathrm{~N}=1200 \mathrm{RPM}$, $70 \%$ Load 


\subsubsection{Effect of $\mathrm{H}_{2}$ Addition on the Emissions of PM}

Figure 78 through Figure 81 shows the effect of $\mathrm{H}_{2}$ additions on $\mathrm{PM}$ emissions. Similar to that of the 1999 Cummins ISM370ESP engine, the addition of $\mathrm{H}_{2}$ to the 2004 Mack MP7 355E engine reduced substantially the PM emissions. As shown in Figure 78, the addition of $\mathrm{H}_{2}$ at 70\% load reduced gradually the emissions of PM. However, the $\mathrm{H}_{2}$ addition at full load operation had negligible effect on PM emissions. As shown in Figure 79, the addition of $\mathrm{H}_{2}(<1 \%)$ reduced substantially the PM emissions. However, the $\mathrm{H}_{2}$ addition beyond $1 \%$ gradually increased the PM emissions until 3.5\%. Then, PM emissions reduced again beyond $3.5 \% \mathrm{H}_{2}$ addition. Figure 80 shows the same trend as $50 \%$ load, the PM emissions reduced substantially until $3 \% \mathrm{H}_{2}$ addition. The PM emissions increased between 3 and $4 \% \mathrm{H}_{2}$ addition and decreased again beyond $4 \% \mathrm{H}_{2}$ addition. With the addition of $\mathrm{H}_{2}$ up to $7.5 \%$ at $10-70 \%$ load, the maximum PM reduction of 65 to $80 \%$ was obtained.

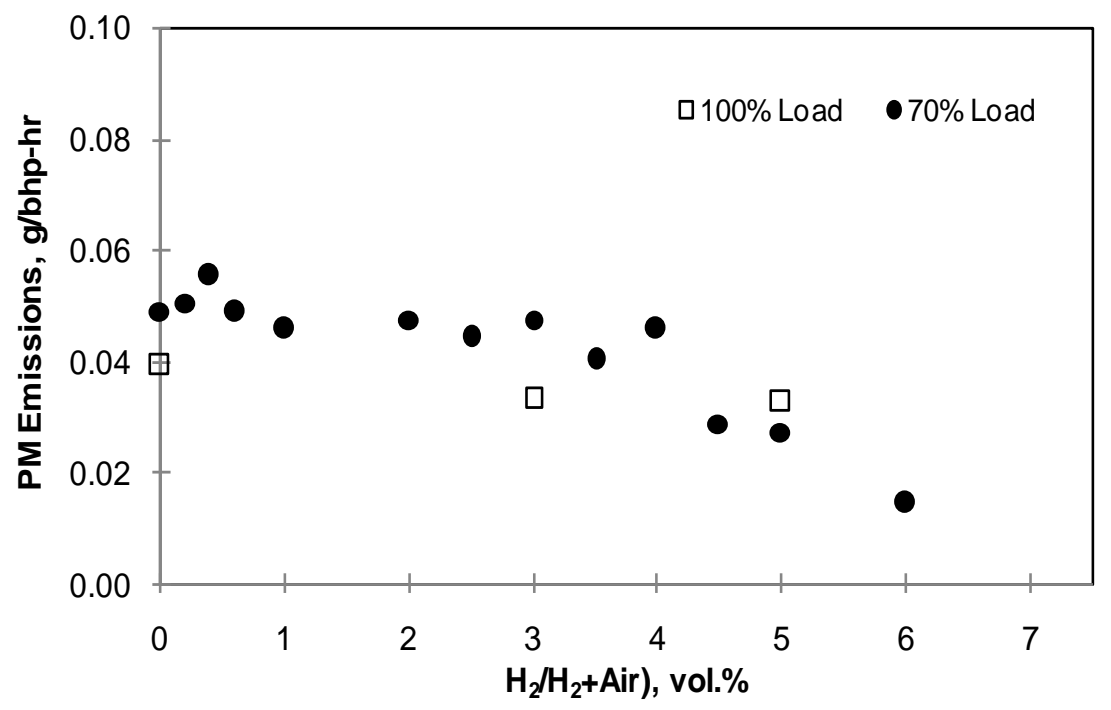

Figure 78 Effect of $\mathrm{H}_{2}$ Addition on the Emissions of PM, N=1200 RPM, 70 and 100\% Load 


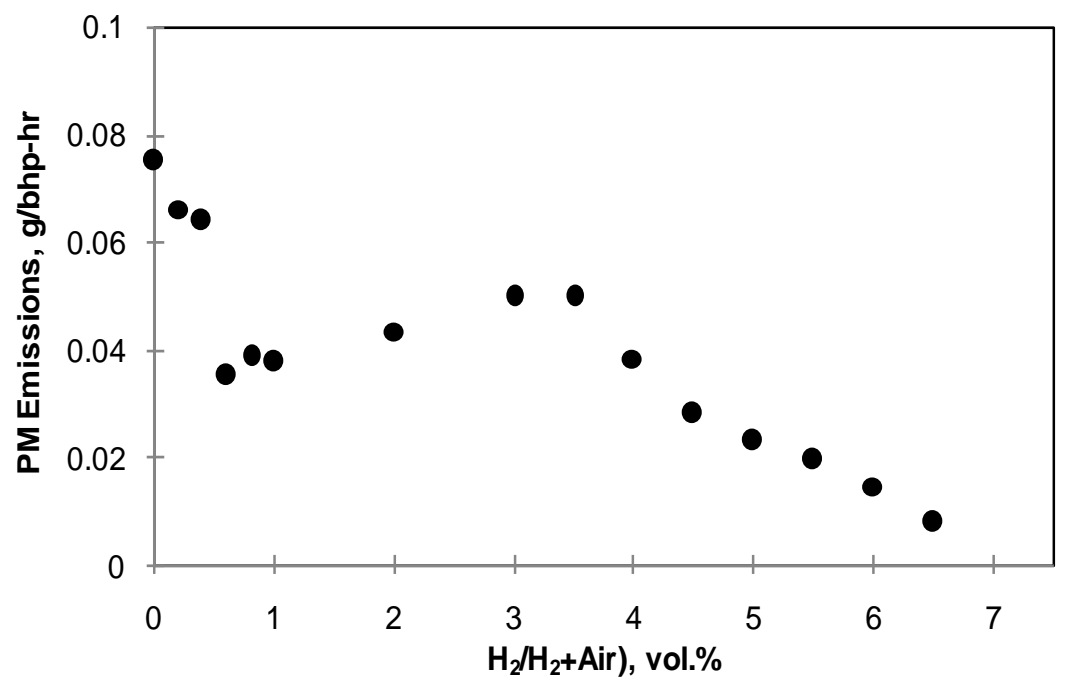

Figure 79 Effect of $\mathrm{H}_{2}$ Addition on the Emissions of PM, N=1200 RPM, 50\% Load

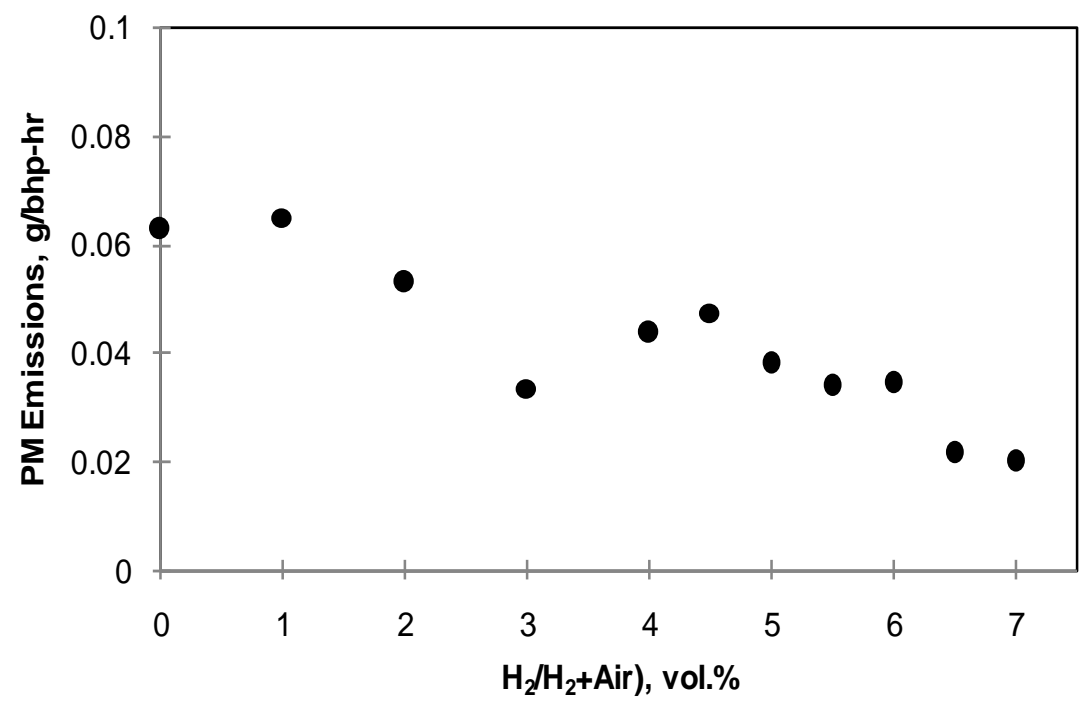

Figure 80 Effect of $\mathrm{H}_{2}$ Addition on the Emissions of PM, N=1200 RPM, 30\% Load

As shown in Figure 81 for low load (10-20\%) operation, the addition of a small amount of $\mathrm{H}_{2}(<3 \%)$ drastically reduced the PM emissions especially for $10 \%$ load. Further increasing the amount of $\mathrm{H}_{2}$ would continue to reduce PM emissions but at a lower rate. 


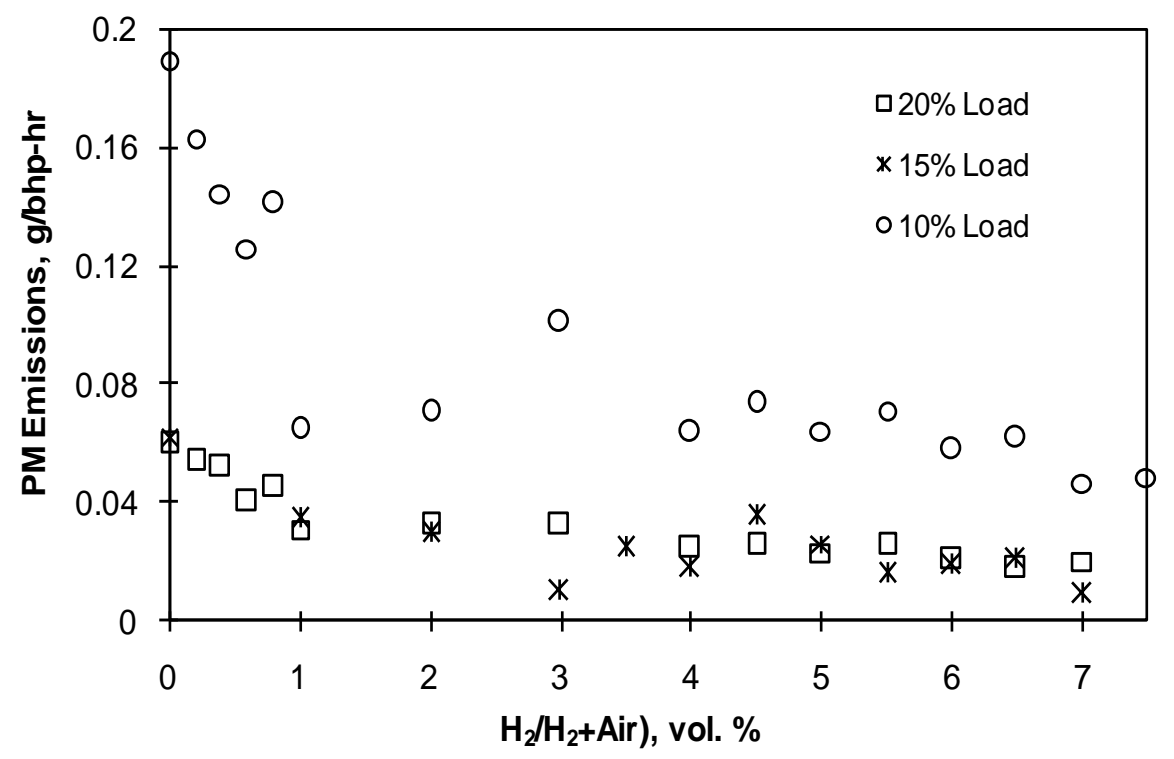

Figure 81 Effect of $\mathrm{H}_{2}$ Addition on the Emissions of PM, N=1200 RPM, 10-20\% Load

\subsubsection{Effect of $\mathrm{H}_{2}$ Addition on the Emissions of $\mathrm{CO}$}

As shown in Figure 82, the addition of $\mathrm{H}_{2}$ at low to medium load reduced the emissions of CO. This was consistent with the experimental results reported in the literature and those obtained in the 1999 Cummins ISM370ESP engine. This may be due to the reduction in the amount of diesel fuel burned and also the enhancement of $\mathrm{H}_{2}$ on oxidation of $\mathrm{CO}$ to $\mathrm{CO}_{2}$. However, the addition of a small amount of $\mathrm{H}_{2}$ at high load operation increased the emissions of $\mathrm{CO}$ with the maximum $\mathrm{CO}$ emissions observed with the addition of $4 \% \mathrm{H}_{2}$ as shown in Figure 83. Further increasing the addition of $\mathrm{H}_{2}$ reduced the emissions of $\mathrm{CO}$. This could be due to the development of the $\mathrm{H}_{2}$ flame, which helps to burn the CO survived the main combustion process. 


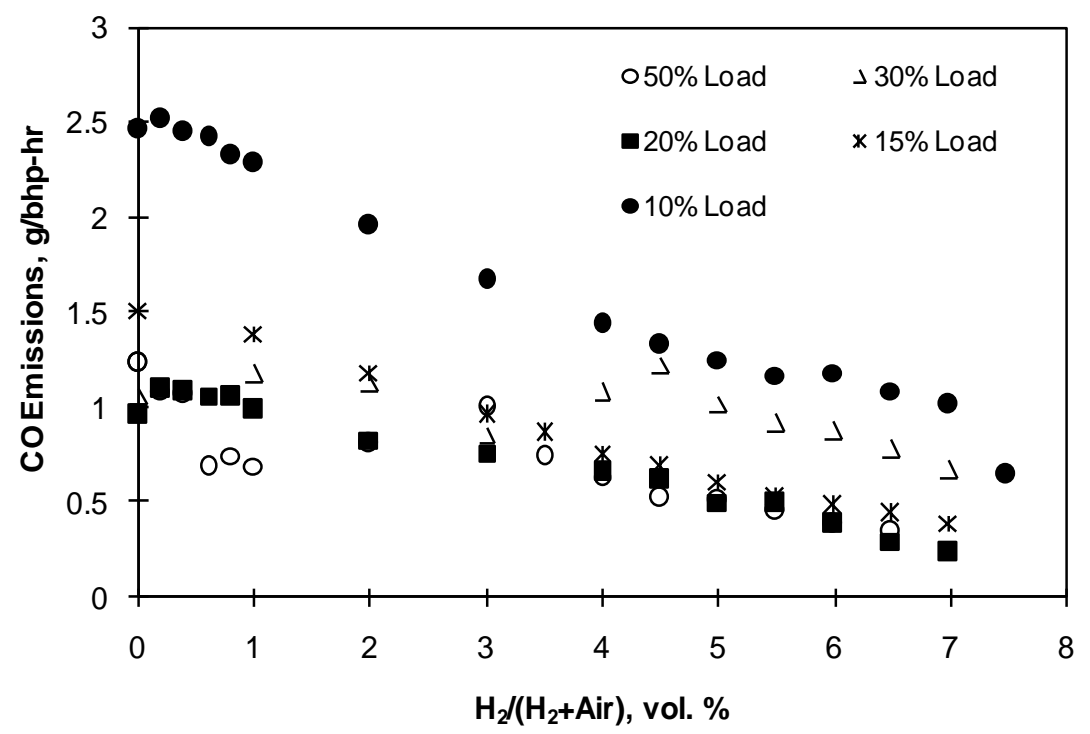

Figure 82 Effect of $\mathrm{H}_{2}$ Addition on the Emissions of CO, N=1200 RPM, 10-50\% Load

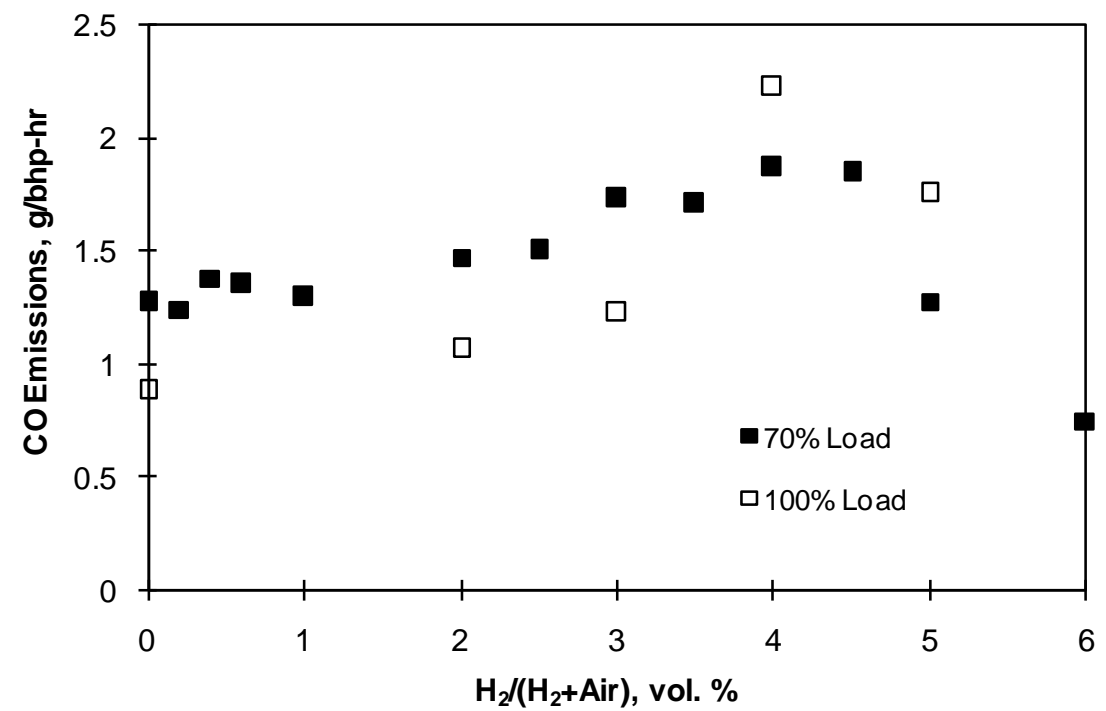

Figure 83 Effect of $\mathrm{H}_{2}$ Addition on the Emissions of CO, N=1200 RPM, 70-100\% Load

\subsubsection{Effect of $\mathrm{H}_{2}$ Addition on the Emissions of $\mathrm{HC}$}

As shown in Figure 84, the addition of $\mathrm{H}_{2}$ had negligible effect on the emissions of $\mathrm{HC}$ at all loads with the exception of $10 \%$ load. The addition of up to $5 \% \mathrm{H}_{2}$ at $10 \%$ load had minor effect on $\mathrm{HC}$ emissions. The addition of $\mathrm{H}_{2}$ beyond $5 \%$ substantially reduced the $\mathrm{HC}$ emissions. 


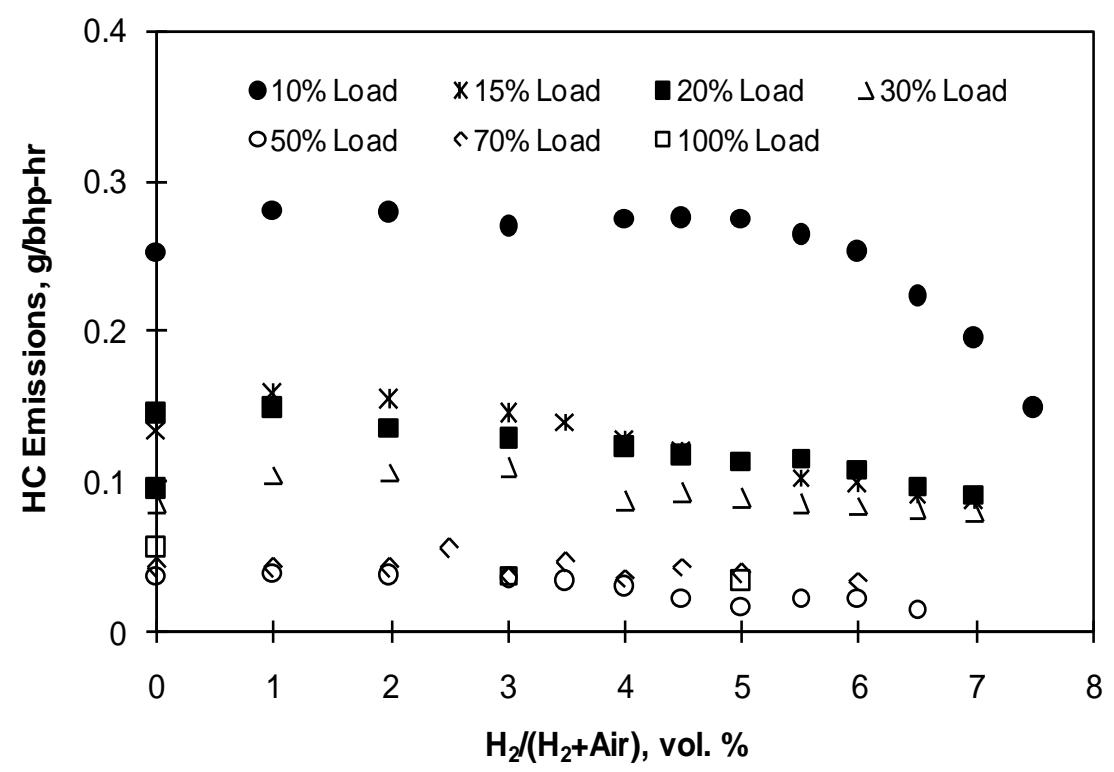

Figure 84 Effect of $\mathrm{H}_{2}$ Addition on the Emissions of HC, N=1200 RPM, 10-100\% Load

\subsubsection{Effect of $\mathrm{H}_{2}$ Addition on the Emissions of $\mathrm{CO}_{2}$}

The effect of $\mathrm{H}_{2}$ addition on the emissions of $\mathrm{CO}_{2}$ can be found in Figure 85. As expected, the addition of $\mathrm{H}_{2}$ into this diesel engine gradually reduced the emissions of $\mathrm{CO}_{2}$. This was due to the reduction in diesel fuel flow and also the improvement in BTE when a relatively large amount of $\mathrm{H}_{2}$ was added. The lower $\mathrm{CO}_{2}$ emissions observed at low load with the addition of large amount of $\mathrm{H}_{2}$ was due mainly to the substitution of large percentage of diesel fuel by $\mathrm{H}_{2}$. As shown in Figure 86, the addition of $6 \% \mathrm{H}_{2}$ at $10 \%$ load contributed up to $51 \%$ of the total intake energy. When operated at $70 \%$ load, the addition of $6 \% \mathrm{H}_{2}$ contributed to $32 \%$ to the total intake energy. 


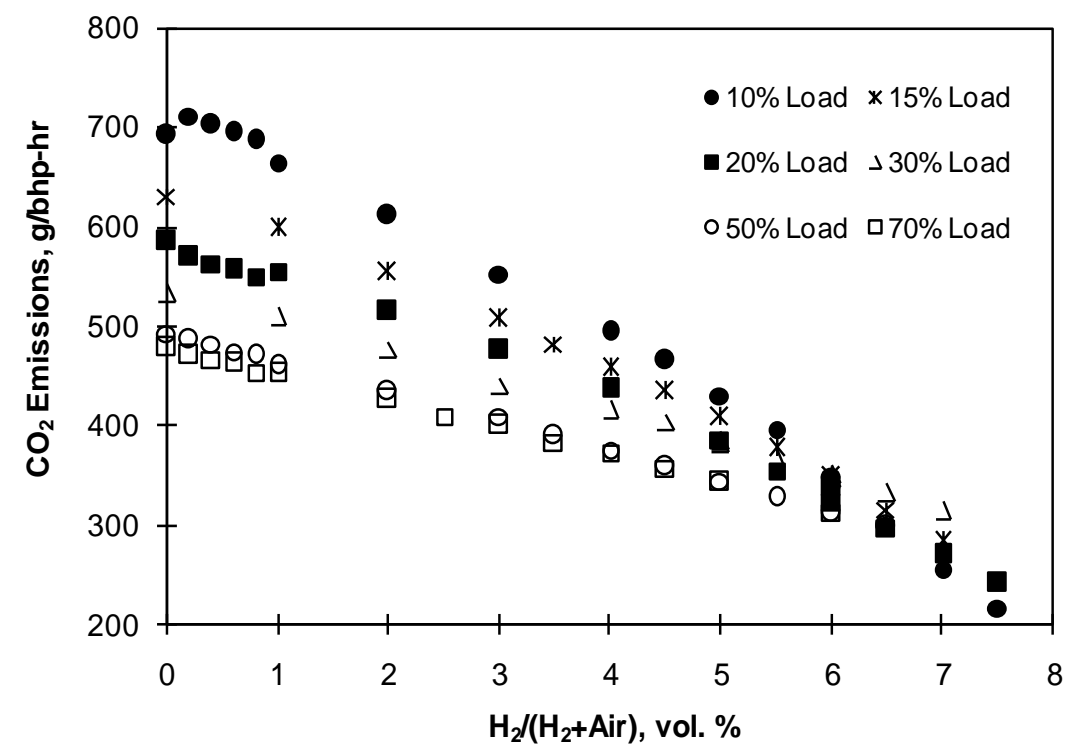

Figure 85 Effect of $\mathrm{H}_{2}$ Addition on the Emissions of $\mathrm{CO}_{2}, \mathrm{~N}=1200 \mathrm{RPM}, 10-70 \%$ Load

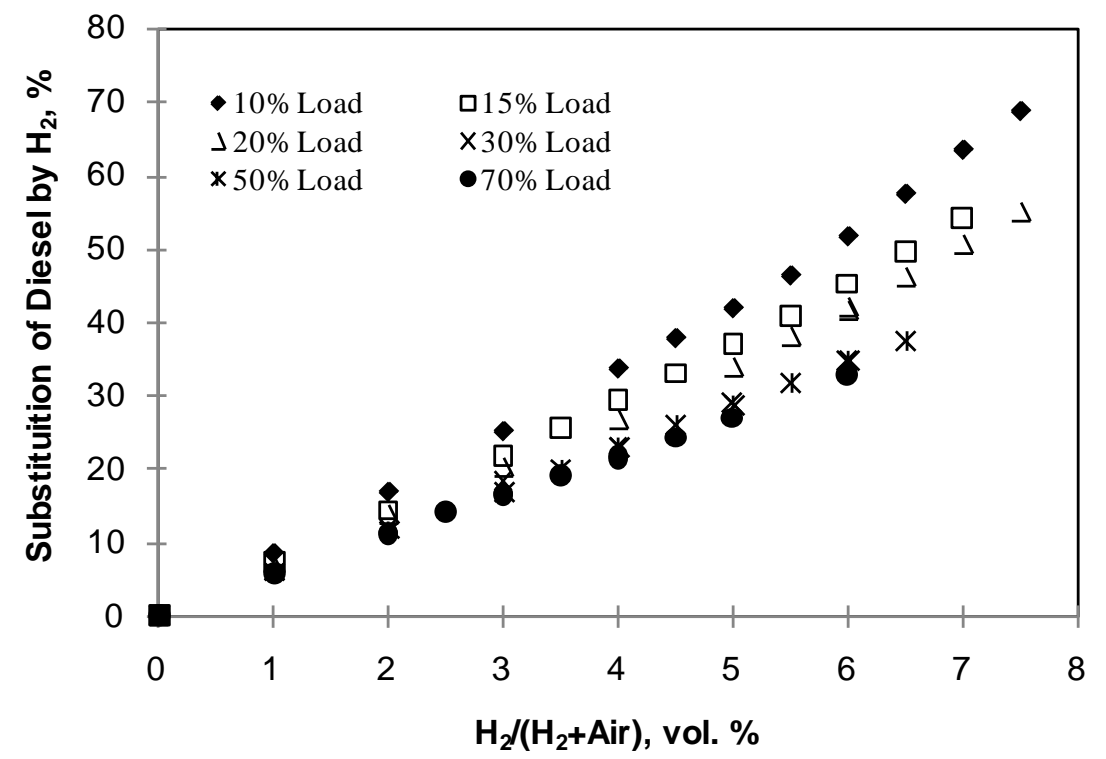

Figure 86 Effect of $\mathrm{H}_{2}$ Addition on Diesel Substitution for 2004 Mack MP7 355E, $\mathrm{N}=1200$ RPM, 10-70\% Load

\subsection{Brake Thermal Efficiency and Its Improvement}

The brake thermal efficiency depends on the combustion efficiency of the fuel, combustion phasing, compression ratio, the heat transfer from the bulk gas to coolant and the mechanical efficiency. As shown in Figure 87, the addition of $\mathrm{H}_{2}$ at $10 \%$ load 
substantially reduced the BTE with its minimum value of $26.1 \%$ observed when the $\mathrm{H}_{2} /\left(\mathrm{H}_{2}+\mathrm{Air}\right)$ reached $4.5 \%$. Further increasing the amount of $\mathrm{H}_{2}$ added beyond $4.5 \%$ improved gradually the BTE. However, the BTE with the addition of $\mathrm{H}_{2}$ at $10 \%$ load was lower than that of pure diesel operation (28.3\%). No benefit in the brake thermal efficiency was obtained with the addition of $\mathrm{H}_{2}$ at $10 \%$ load.

Benefiting from the improved $\mathrm{H}_{2}$ combustion efficiency, the positive effect of the addition of $\mathrm{H}_{2}$ in improving the BTE was observed at higher load operation. As shown in Figure 88 for $20 \%$ load operation, the improved BTE was observed when the $\mathrm{H}_{2}$ addition reached $5.5 \%$. With the addition of $7.5 \% \mathrm{H}_{2}$ into the intake mixture, the BTE of $36.3 \%$ was observed. Compared to pure diesel operation, the BTE was improved from 35.2 to $36.3 \%$ with $3.1 \%$ improvement.

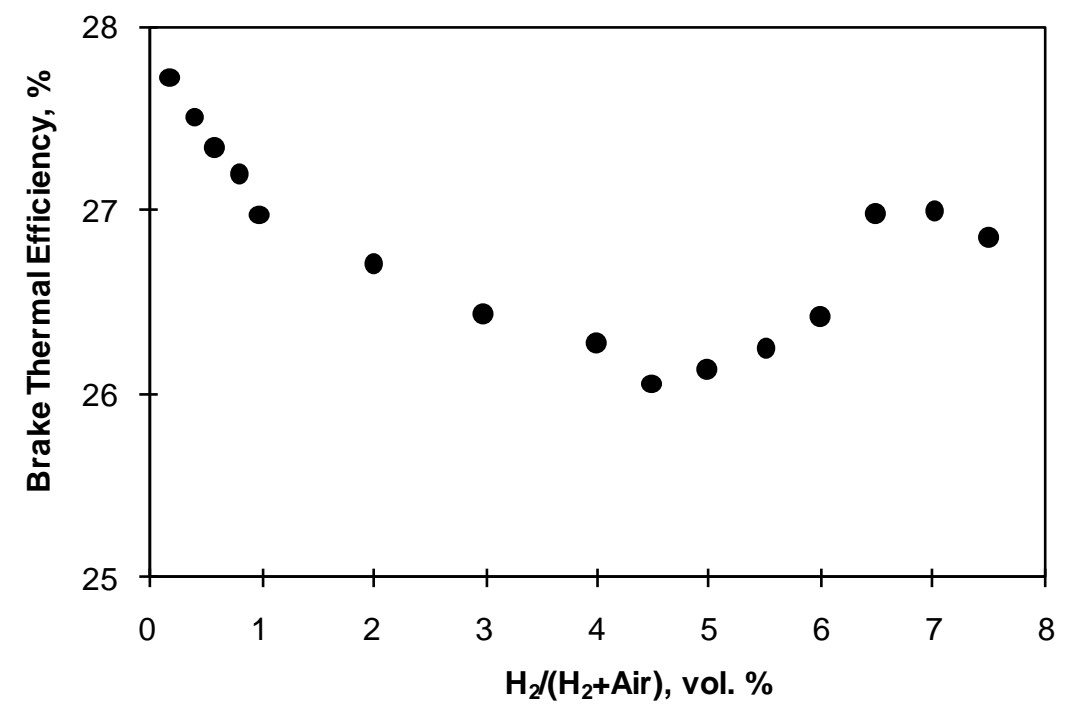

Figure 87 Effect of $\mathrm{H}_{2}$ Addition on the BTE, N=1200 RPM, 10\% Load 


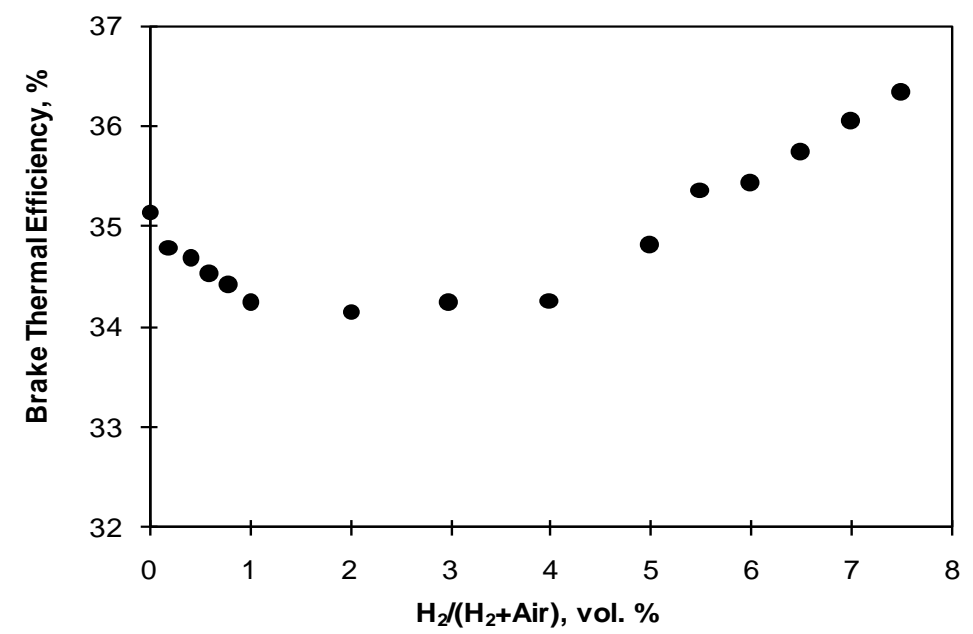

Figure 88 Effect of $\mathrm{H}_{2}$ Addition on the BTE, N=1200 RPM, 20\% Load

Benefiting from the improvement of $\mathrm{H}_{2}$ combustion efficiency and also an enhanced combustion process with the increasing engine load, the penalty in BTE was gradually limited to the lower $\mathrm{H}_{2}$ addition range as shown in Figure 89. When operated at medium to high load, the negative effect of $\mathrm{H}_{2}$ addition on the BTE was only observed when a small amount of $\mathrm{H}_{2}(<1 \%)$ was added as shown in Figure 90 for 50, 70, and 100\% load operation.

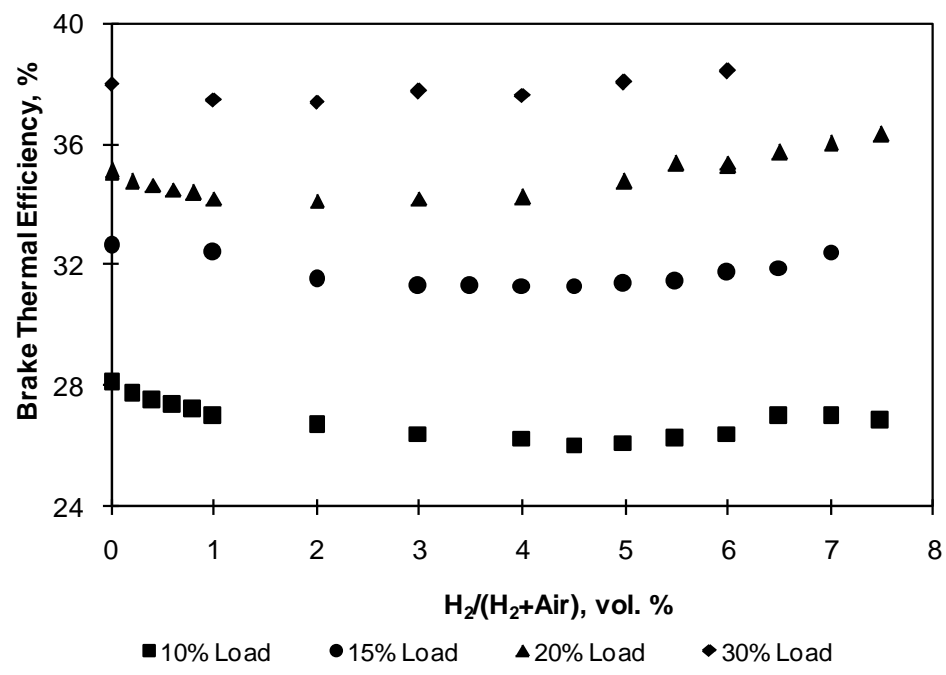

Figure 89 Effect of $\mathrm{H}_{2}$ Addition and Engine Load on BTE under Low Load Operation, $\mathrm{N}=1200$ RPM, 10-30\% Load 


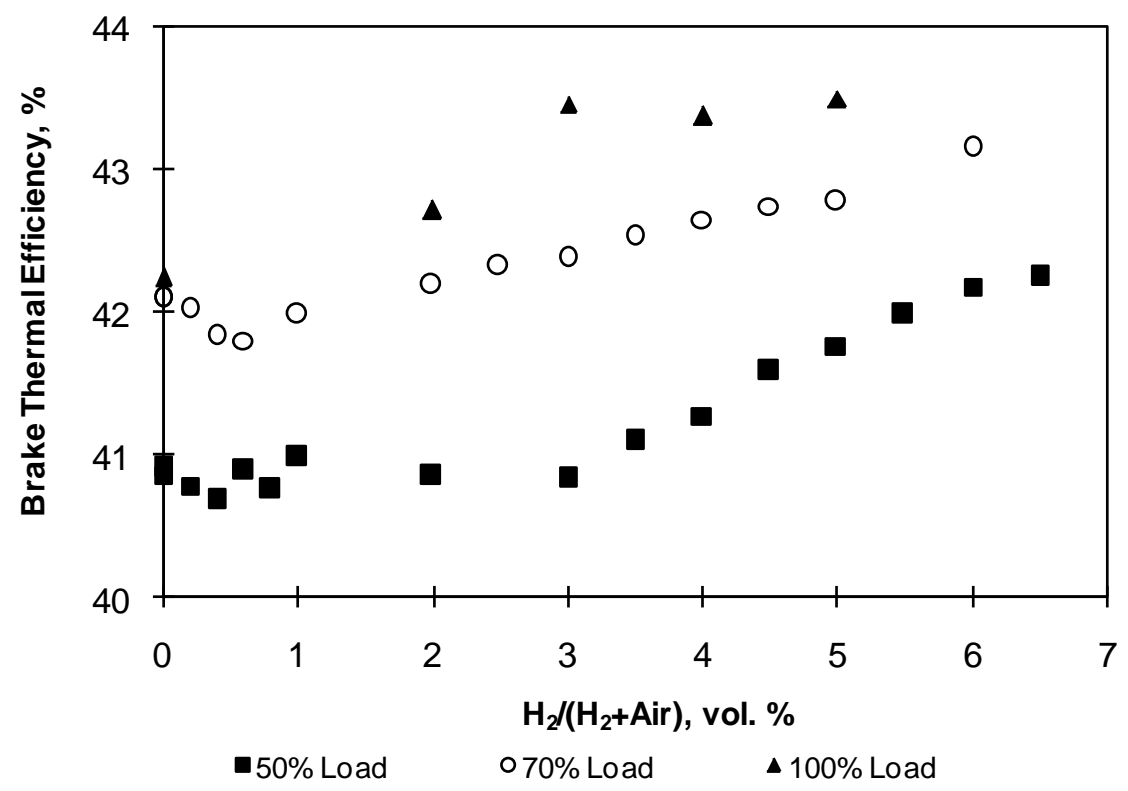

Figure 90 Effect of $\mathrm{H}_{2}$ Addition and Engine Load on BTE When Operated from Medium to High Load Operation, N=1200 RPM (For 100\% Operation, 2 and 4\% $\mathrm{H}_{2}$ Data Was Measured at 1225 RPM)

The effect of $\mathrm{H}_{2}$ addition on the BTE was also explored by examining the improvement to the BTE relative to that of pure diesel operation. As shown in Figure 91, the positive effect of $\mathrm{H}_{2}$ addition on the BTE could only be obtained when a relatively large amount of $\mathrm{H}_{2}$ was added at loads higher than $15 \%$. With the increasing engine load, the positive effect of $\mathrm{H}_{2}$ addition in improving BTE could be obtained with the addition of less $\mathrm{H}_{2}$. As shown in Figure 92 for medium to high load operation, the improvement of BTE can be obtained with the addition of $\mathrm{H}_{2}$ as low as 1\%. 


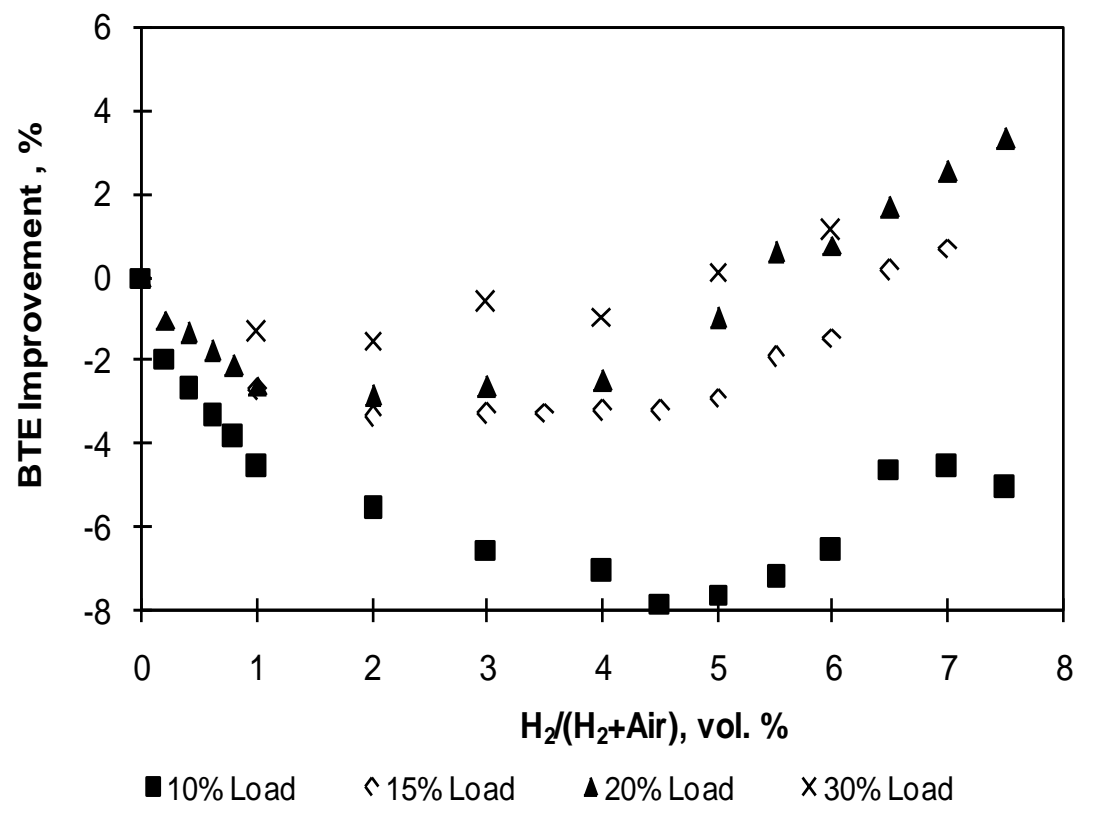

Figure 91 Effect of $\mathrm{H}_{2}$ Addition and Engine Load in Improving the BTE under Low Load Operation, N=1200 RPM, 10-30\% Load

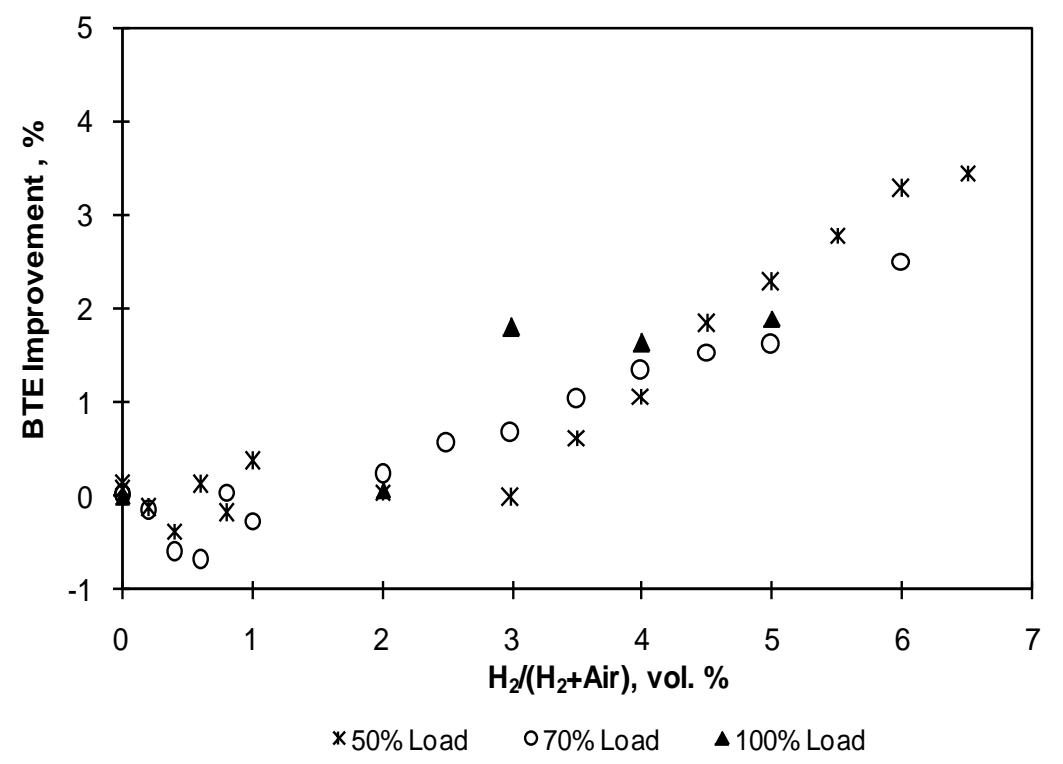

Figure 92 Effect of $\mathrm{H}_{2}$ Addition and Engine Load in Improving the BTE under Medium to High Load Operation, N=1200 RPM, 50-100\% Load

The effect of the engine load on the improvement to the BTE was also examined with the addition of $6 \% \mathrm{H}_{2}$ into the intake mixture. As shown in Figure 93, the maximum 
benefit on the BTE for the 2004 Mack MP7 355E was about 4\%. Compared to that of the 1999 Cummins ISM370ESP engine, the addition of $\mathrm{H}_{2}$ to the 2004 Mack MP7 355E engine was less effective in improving the BTE, especially at low load operation. Due to the application of EGR, the addition of $\mathrm{H}_{2}$ to 2004 Mack MP7 355E substituted less diesel fuel from the reduced intake air flow rate. This was supported by the data shown in Figure 16 and Figure 86, respectively.

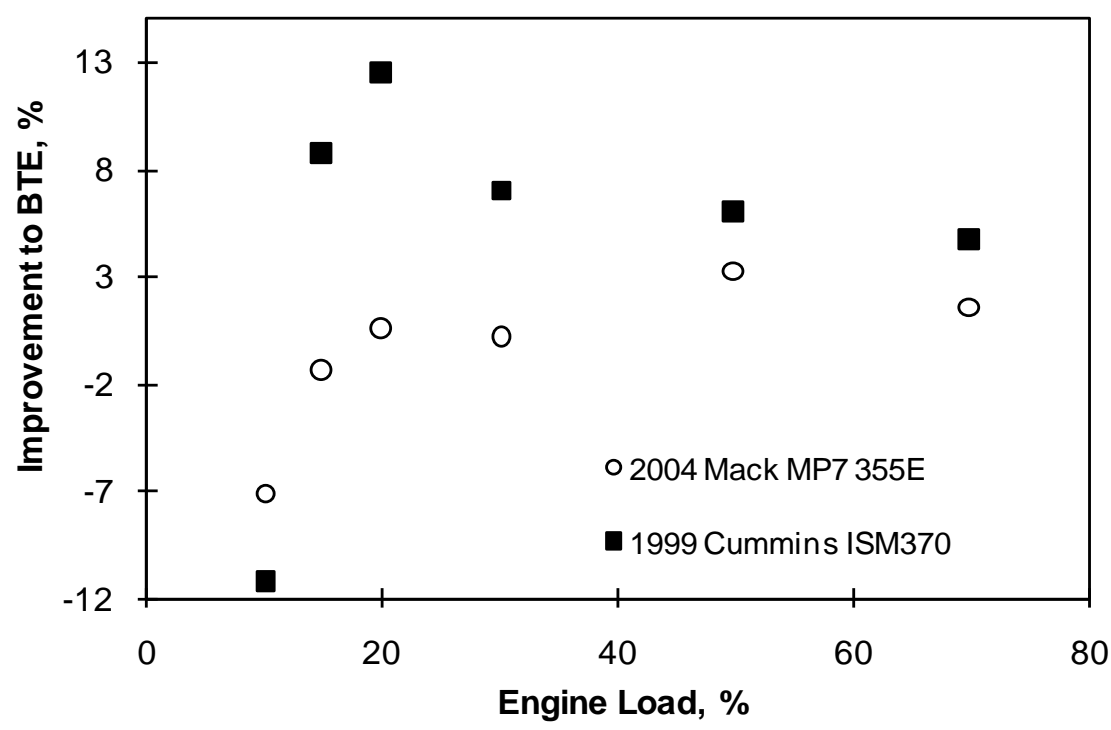

Figure 93 Effect of Engine Load on BTE Improvement with the Addition of $6 \% \mathrm{H}_{2}$, $\mathrm{N}=1200 \mathrm{RPM}$

Figure 94 compared the effect of engine load on the minimum $\mathrm{H}_{2}$ supplementation rate needed to achieve a positive effect on the brake thermal efficiency of both engines. It was shown that more $\mathrm{H}_{2}$ was needed for the 2004 Mack MP7 355E to obtain a positive effect in improving the BTE. This may be due to the application of cooled EGR in the 2004 Mack MP7 355E engine. 


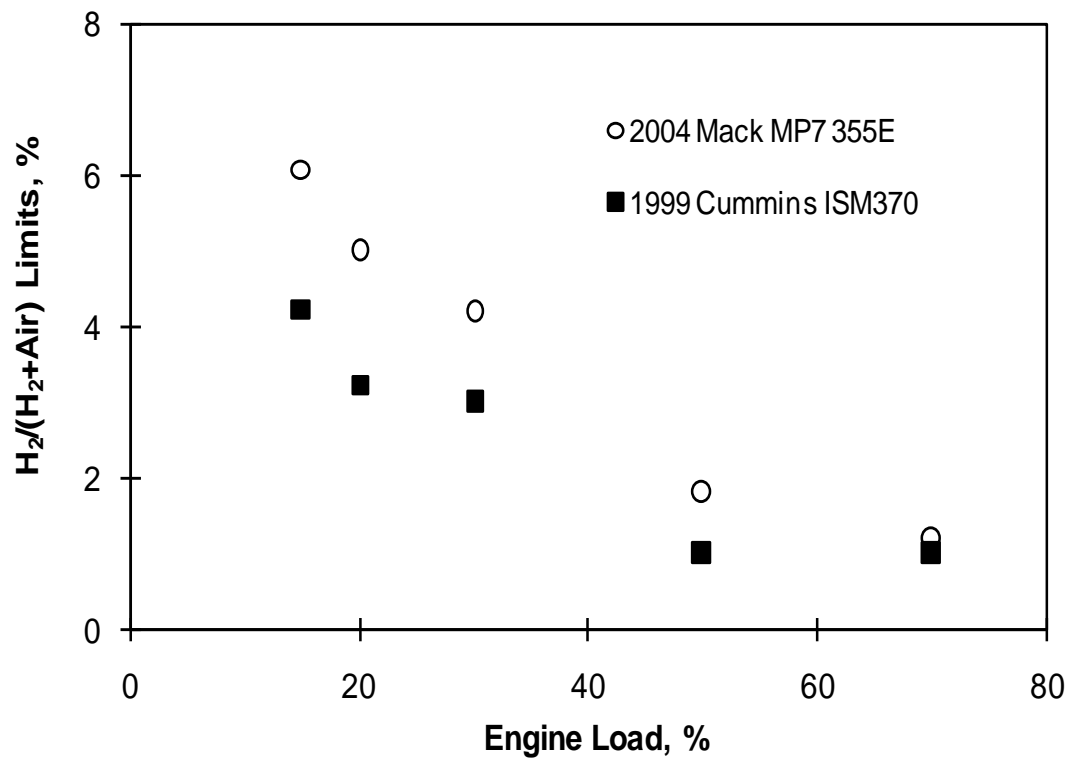

Figure 94 Effect of Engine Load on the Minimum $\mathrm{H}_{2}$ Supplementation Rate Needed for Positive Effect on BTE, N=1200 RPM

For constant diesel fuel flow rate operation, engine load was varied by altering the amount of $\mathrm{H}_{2}$ added. As shown in Figure 95, the addition of a small amount of $\mathrm{H}_{2}$ slightly deteriorated the BTE compared to the burning of pure diesel. The addition of $\mathrm{H}_{2}$ beyond 4\% improved the BTE. A similar result was obtained for the addition of $\mathrm{H}_{2}$ at a higher diesel flow rate. As shown in Figure 96, the positive effect on BTE was obtained for the addition of $\mathrm{H}_{2}$ beyond $3 \%$. 


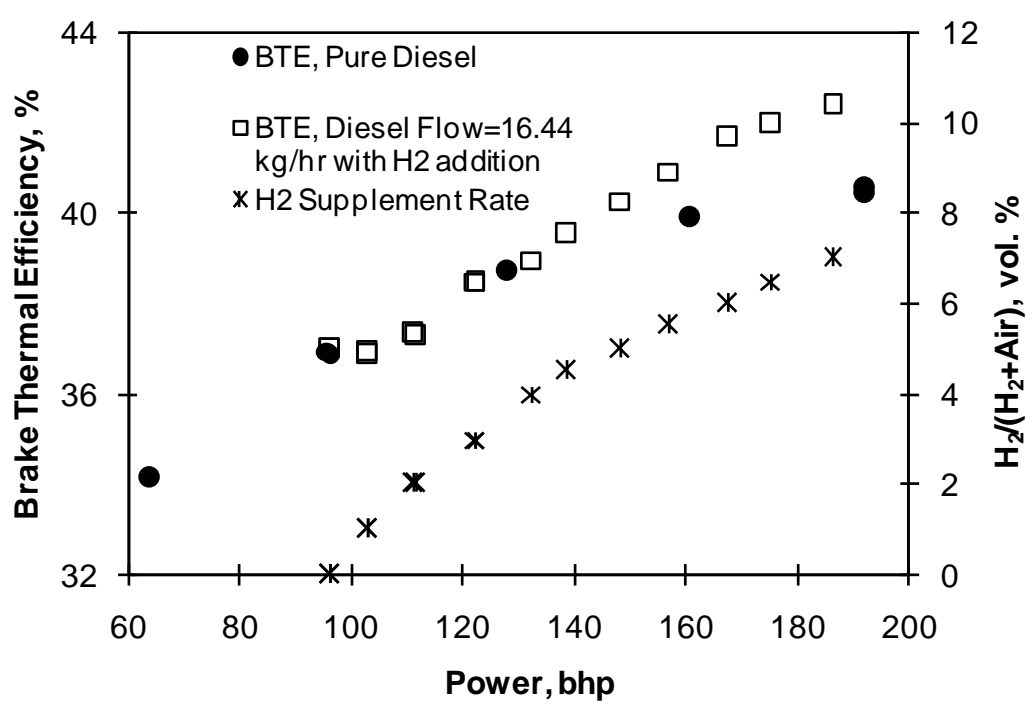

Figure 95 Effect of $\mathrm{H}_{2}$ Addition on the BTE, $\mathrm{N}=1200$ RPM. For Constant Diesel Fuel Flow Rate (16.44 kg/hr) Operation, Engine Load Was Changed by the Addition of $\mathrm{H}_{2}$

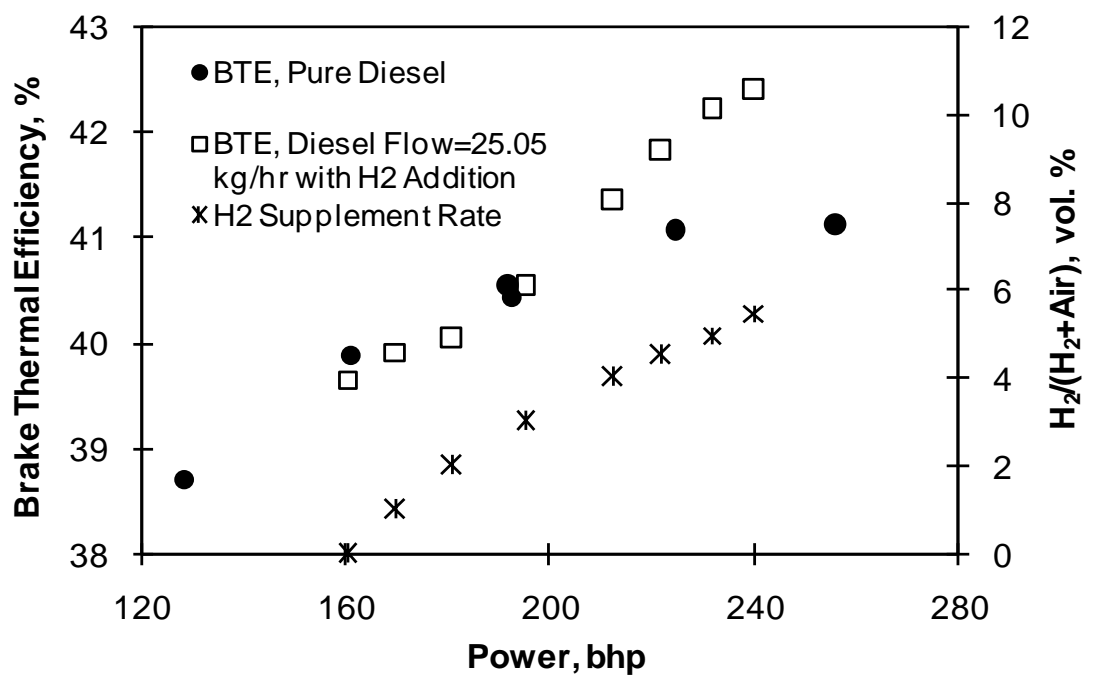

Figure 96 Effect of $\mathrm{H}_{2}$ Addition on the BTE, N=1200 RPM. For Constant Diesel Fuel Flow Rate (25.05 kg/hr) Operation, Engine Load Was Changed by the Addition of $\mathrm{H}_{2}$

\subsection{Effect of $\mathrm{H}_{2}$ Addition on Cylinder Pressure and Heat Release Process}

The addition of $\mathrm{H}_{2}$ into this diesel engine at high load significantly enhanced the combustion process. As shown in Figure 97 for $70 \%$ load operation, the addition of $\mathrm{H}_{2}$ increased the cylinder pressure after combustion was initiated. As shown in Figure 98, 
the addition of a small amount of $\mathrm{H}_{2}(<3 \%)$ increased the peak cylinder pressure with negligible effect on the phasing when peak cylinder pressure was observed. However, further increasing the addition of $\mathrm{H}_{2}$ beyond $3 \%$ continued to increase the peak cylinder pressure but at advanced the phasing when peak cylinder pressure was observed.

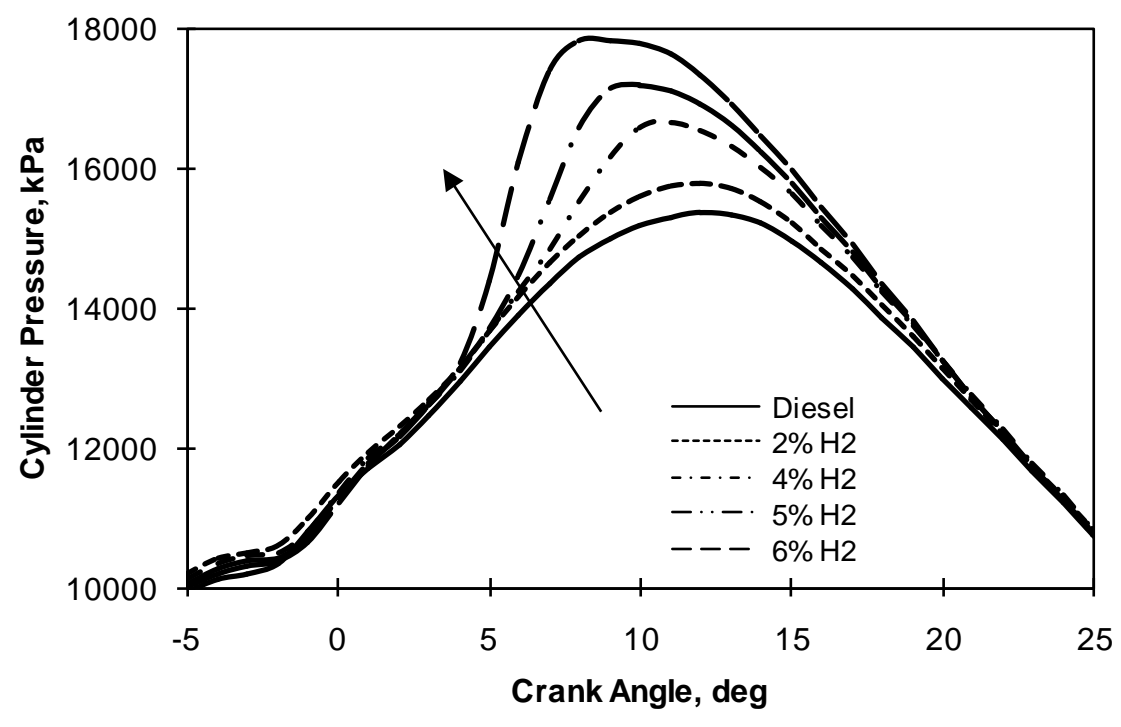

Figure 97 Effect of $\mathrm{H}_{2}$ Addition on Cylinder Pressure, N=1200 RPM, 70\% Load

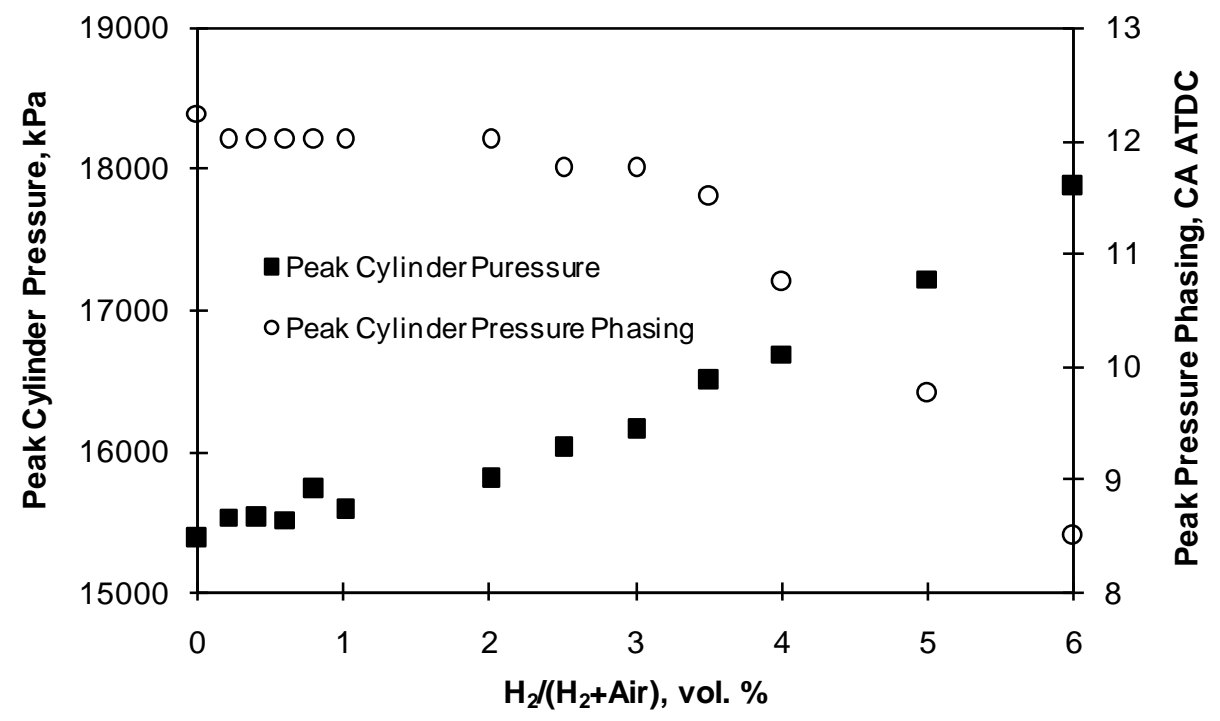

Figure 98 Effect of $\mathrm{H}_{2}$ Addition on Peak Cylinder Pressure and Its Phasing, N=1200 RPM, 70\% Load 
As shown in Figure 99, the addition of $\mathrm{H}_{2}$ was shown to slightly retard the phasing of the premixed combustion. As shown in Table 22, the slight retarding to the phasing of premixed combustion was due to the slightly retarded fuel injection timing and also the slightly longer ignition delay. This made the premixed combustion slightly stronger as more diesel fuel was well mixed with air and ready to be burned in the premixed combustion stage. Also, the addition of $\mathrm{H}_{2}$ to the diesel engine enhanced the heat release rate during the switching process between premixed combustion and diffusion combustion. When $\mathrm{H}_{2} /\left(\mathrm{H}_{2}+\right.$ air $)$ reached $6 \%$, the induction period from premixed combustion to mixing controlled diffusion combustion became negligible. It seems that the premixed combustion may have ignited the $\mathrm{H}_{2}$-air mixture prior to the initiation of diffusion combustion of diesel fuel.

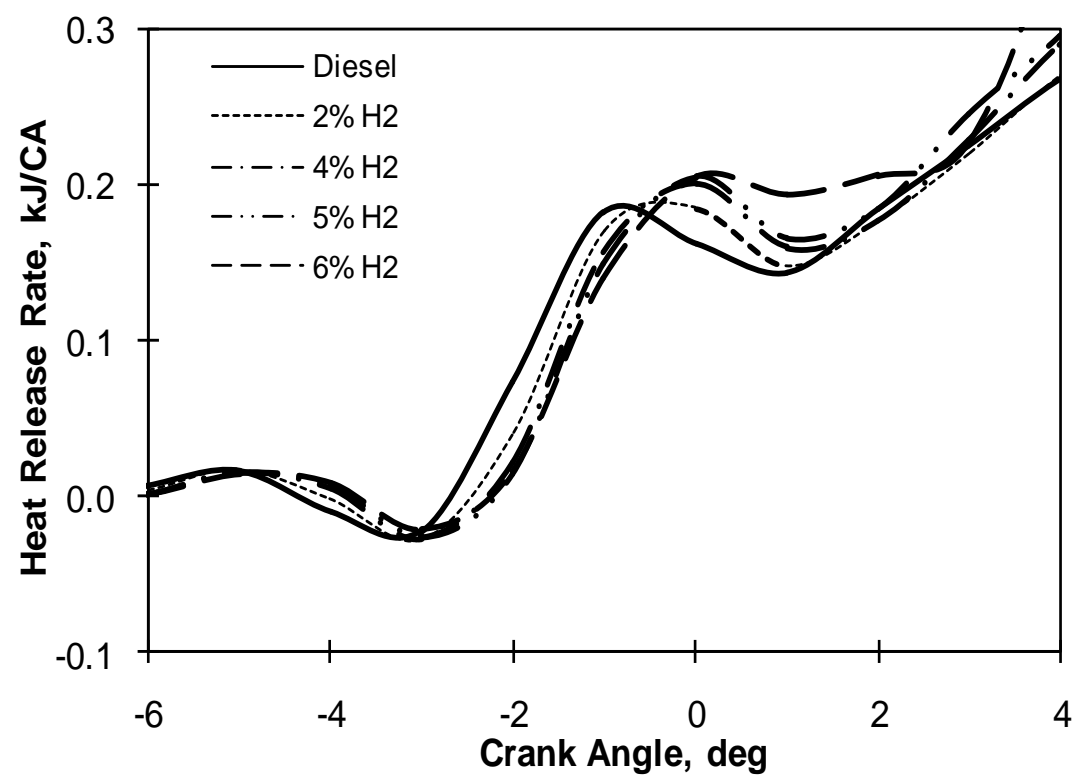

Figure 99 Effect of $\mathrm{H}_{2}$ Addition on Premixed Combustion, N=1200 RPM, 70\% Load 
Table 22 Effect of $\mathrm{H}_{2}$ Addition on SOI, SOC, and Ignition Delay When Operated at 1200 RPM, 70\% Load

\begin{tabular}{|c|c|c|c|}
\hline $\begin{array}{c}\mathbf{H}_{\mathbf{2}} /\left(\mathbf{H}_{\mathbf{2}}+\text { Air), }\right. \\
\mathbf{\%}\end{array}$ & $\begin{array}{c}\text { Start of Injection, CA } \\
\text { ATDC }\end{array}$ & $\begin{array}{c}\text { Start of Combustion, CA } \\
\text { ATDC }\end{array}$ & $\begin{array}{c}\text { Ignition Delay, } \\
\text { CA }\end{array}$ \\
\hline 0 & -7.15 & -2.20 & 4.95 \\
\hline 2 & -7.10 & -1.95 & 5.15 \\
\hline 4 & -6.95 & -1.75 & 5.20 \\
\hline 5 & -6.95 & -1.70 & 5.25 \\
\hline 6 & -6.90 & -1.68 & 5.22 \\
\hline
\end{tabular}

The effect of $\mathrm{H}_{2}$ addition on the heat release process of the diffusion combustion is shown in Figure 100. The addition of $\mathrm{H}_{2}$ at $70 \%$ load has more significant effect on diffusion combustion compared to premixed combustion. The addition of $\mathrm{H}_{2}$ over $2 \%$ enhanced gradually the heat release rate during the middle stage of diffusion combustion. When the concentration of $\mathrm{H}_{2}$ reached $4 \%$ in the intake mixture, the enhanced late diffusion combustion developed gradually to the peak heat release rate at a later phasing compared to diesel combustion. As shown in Figure 101 for the addition of $6 \% \mathrm{H}_{2}$, the featured two-stage combustion process of the diesel engine developed into a three-stage combustion process of dual fuel engine including premixed diesel combustion, early stage diesel diffusion combustion, the combustion of $\mathrm{H}_{2}$ by propagating turbulent flames and late stage diffusion combustion of diesel fuel. The enhanced heat release peak in diffusion combustion represented a combination of the diffusion combustion of diesel fuel and the propagation of multi turbulent $\mathrm{H}_{2}$-air flames. Also, the combustion of $\mathrm{H}_{2}$ finished earlier than the slow diesel diffusion combustion. The fast burning of $\mathrm{H}_{2}$ fuel 
contributed to the advanced phasing of peak cylinder pressure obtained in $\mathrm{H}_{2}$-diesel dual fuel combustion mode.

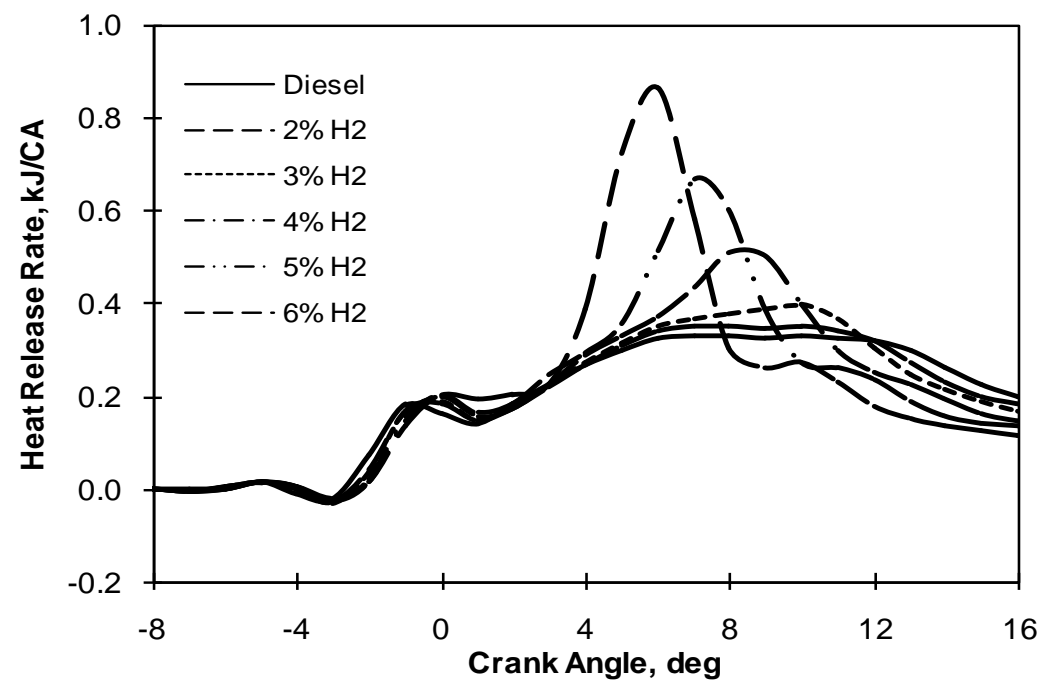

Figure 100 Effect of $\mathrm{H}_{2}$ Addition on Heat Release Process, N=1200 RPM, 70\% Load

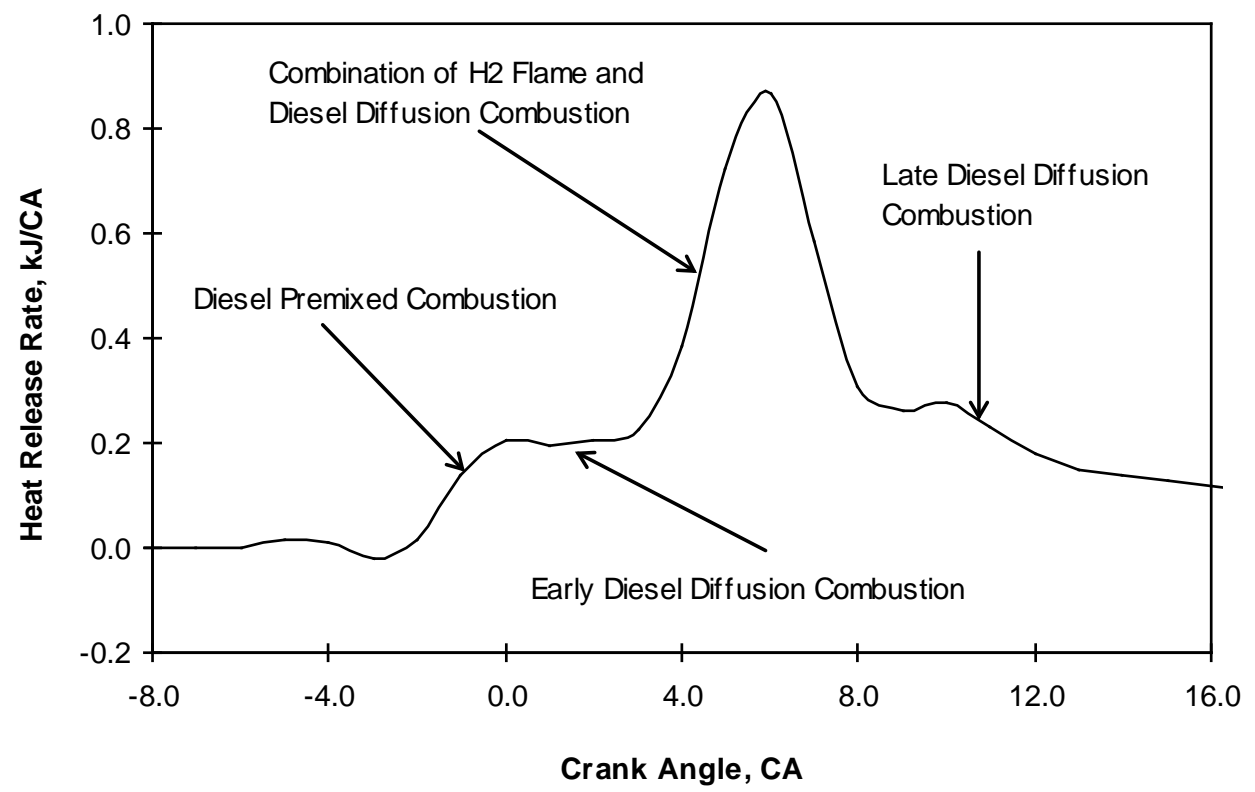

Figure 101 The Heat Release Process of $\mathrm{H}_{2}$-Diesel Dual Fuel Engine Operation, $\mathrm{N}=1200$ RPM, 70\% Load, $\mathrm{H}_{2} /\left(\mathrm{H}_{2}+\right.$ Air $)=6 \%$, vol.

Figure 102 shows the effect of $\mathrm{H}_{2}$ addition on the peak heat release rate and its phasing. The addition of a small amount of $\mathrm{H}_{2}(<3 \%)$ slightly increased the peak heat 
release rate but had negligible effect on the phasing when peak heat release rate was observed. A sudden retard in phasing of peak heat release rate with the addition of 2.5 and $3 \% \mathrm{H}_{2}$ was due to the development of peak heat release rate obtained at late stage of diffusion combustion. As described before, this late heat release bump was due to the gradual development of $\mathrm{H}_{2}$ combustion. As shown in Figure 102, further increasing the amount of $\mathrm{H}_{2}$ beyond 3\% was found to drastically enhance the combustion process represented by the increased peak heat release rate observed at substantially advanced phasing.

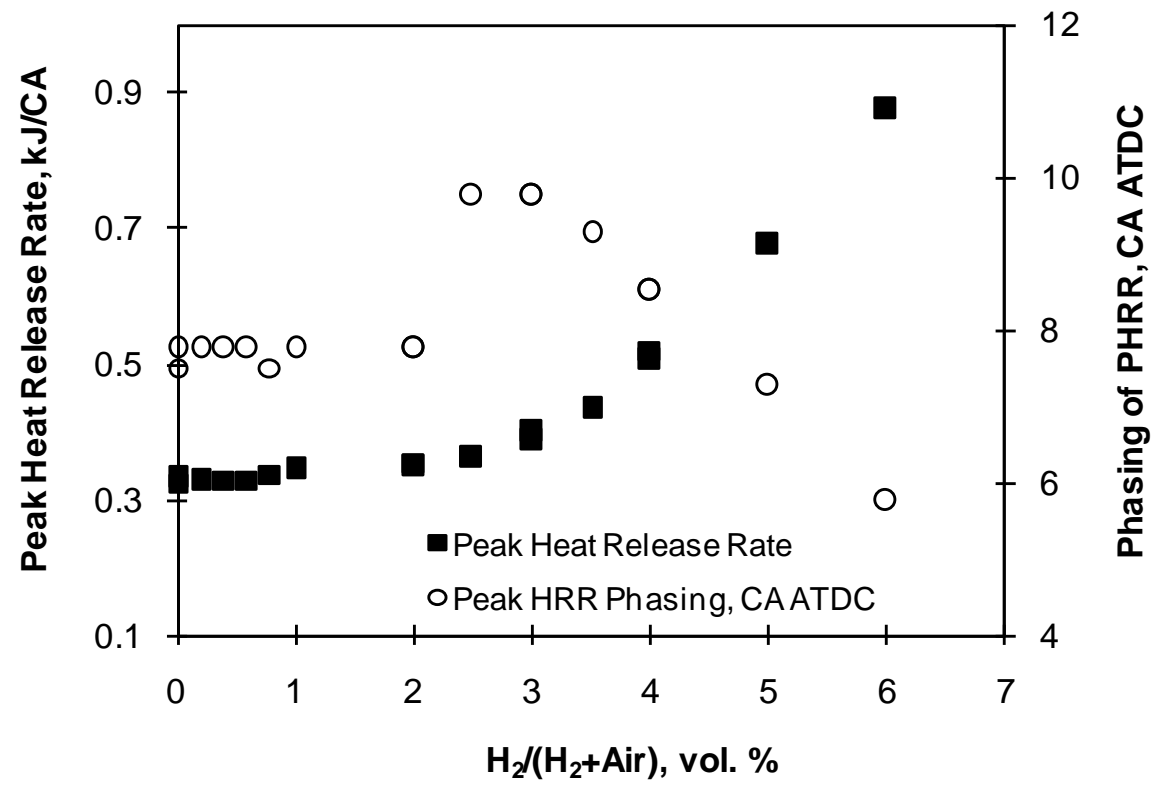

Figure 102 Effect of $\mathrm{H}_{2}$ Addition on Peak Heat Release Rate and Its Phasing, N=1200 RPM, 70\% Load

Figure 103 to Figure 107 shows the effect of $\mathrm{H}_{2}$ addition on the variation of cylinder pressure and heat release process for $50 \%$ load operation. As shown in Figure 103 and Figure 104, the addition of a small amount of $\mathrm{H}_{2}(<3 \%)$ increased slightly the peak cylinder pressure but had negligible effect on its phasing. Similar to $70 \%$ load operation, the sudden retard in the phasing of peak cylinder pressure for 3.5 and $4 \% \mathrm{H}_{2}$ 
addition, as shown in Figure 104, was due to the development of the second heat release peak in diffusion combustion as shown in Figure 106. Increasing the amount of $\mathrm{H}_{2}$ added beyond $5 \%$ was found to drastically increase the peak cylinder pressure with gradually advanced phasing as shown in Figure 107.

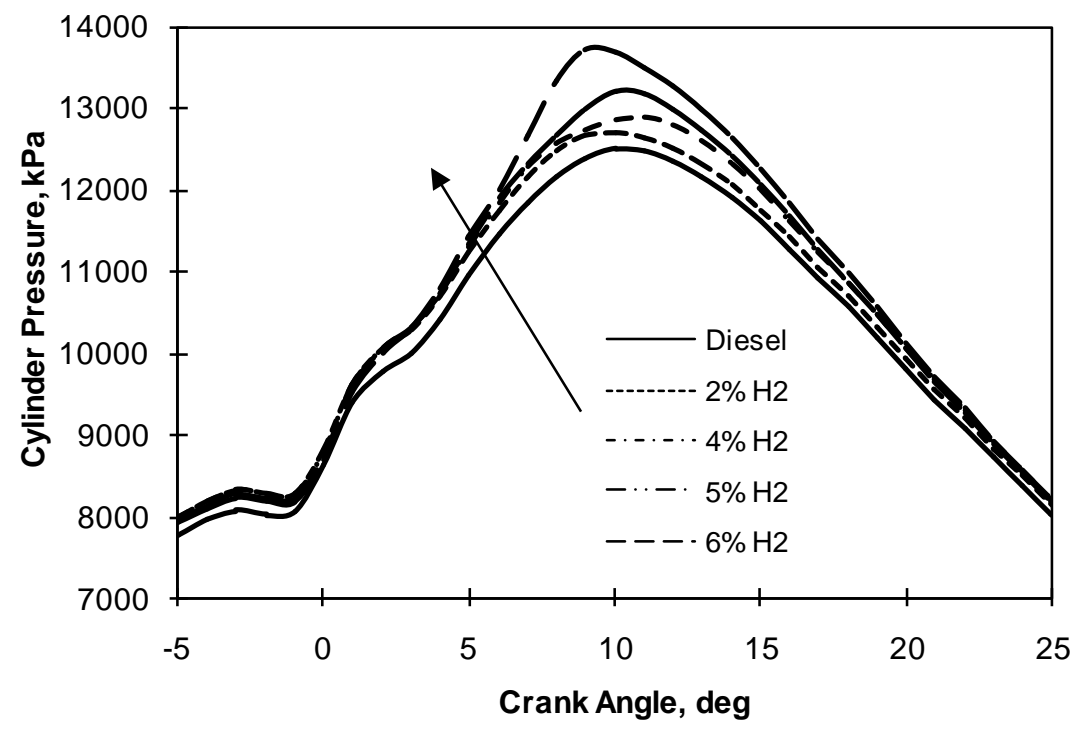

Figure 103 Effect of $\mathrm{H}_{2}$ Addition on Cylinder Pressure, N=1200 RPM, 50\% Load

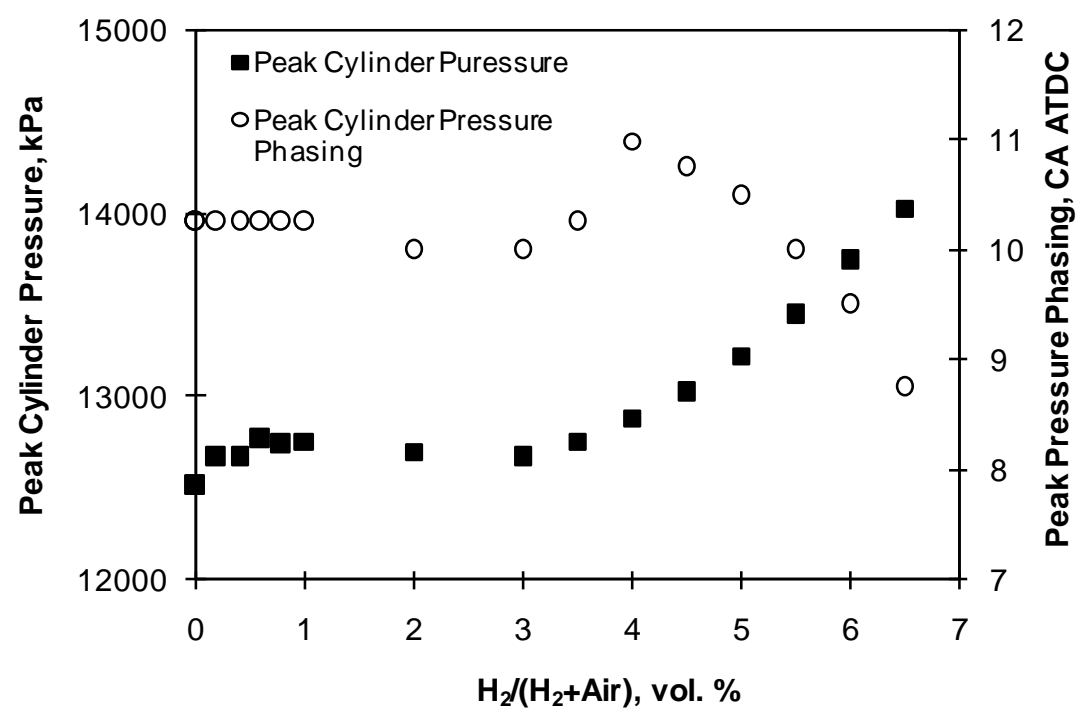

Figure 104 Effect of $\mathrm{H}_{2}$ Addition on Peak Cylinder Pressure and Its Phasing, N=1200 RPM, 50\% Load 
As shown in Figure 105, the addition of a small amount of $\mathrm{H}_{2}(<4.5 \%)$ increased slightly the peak heat release rate with negligible effect on its phasing. Also, the addition of $\mathrm{H}_{2}$ was found to enhance the late diffusion combustion as shown by the gradual development of the second heat release peak observed at late diffusion combustion as shown in Figure 106. Further increasing the addition of $\mathrm{H}_{2}$ enhanced and advanced the heat release peak associated with $\mathrm{H}_{2}$ until it merged with that of diesel diffusion combustion as shown in Figure 107 for the addition of $6 \% \mathrm{H}_{2}$. In comparison, the addition of $\mathrm{H}_{2}$ at $50 \%$ load had negligible effect on the premixed combustion process.

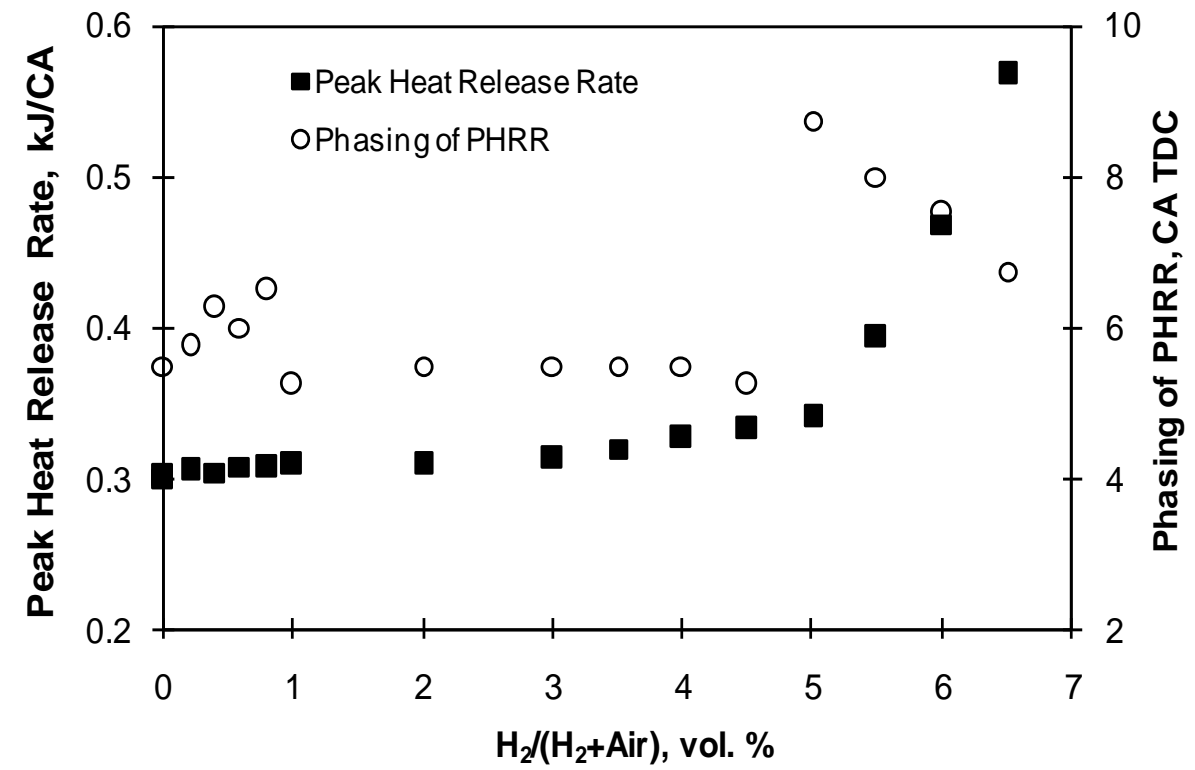

Figure 105 Effect of $\mathrm{H}_{2}$ Addition on Peak Heat Release Rate and Its Phasing, $\mathrm{N}=1200$ RPM, 50\% Load 


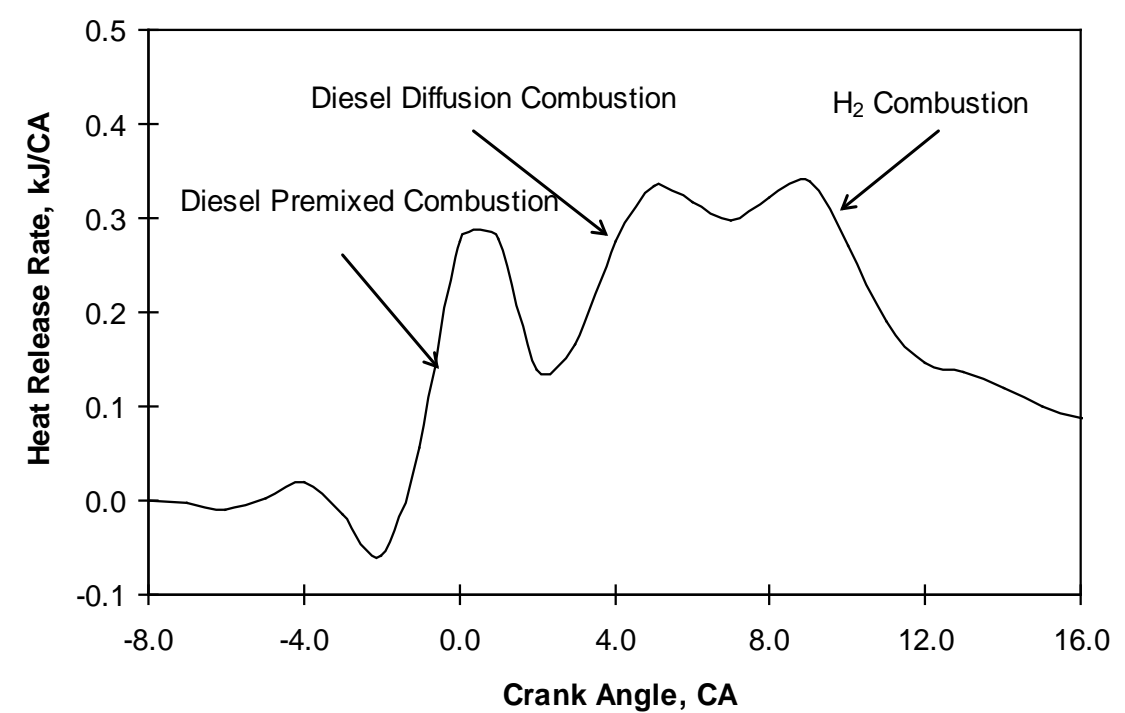

Figure 106 Effect of $\mathrm{H}_{2}$ Addition Heat Release Rate, N=1200 RPM, 50\% Load, $\mathrm{H}_{2} /\left(\mathrm{H}_{2}+\right.$ Air $)=5 \%$, vol.

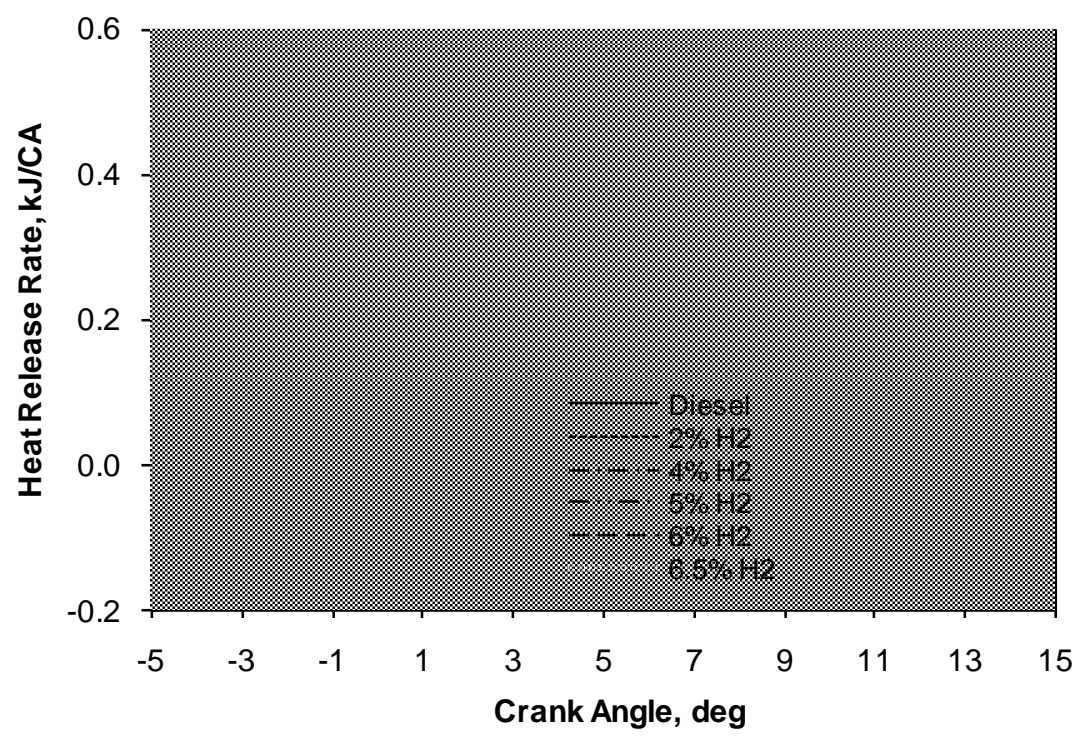

Figure 107 Effect of $\mathrm{H}_{2}$ Addition on Heat Release Rate, N=1200 RPM, 50\% Load

Figure 108 to Figure 111 shows the effect of $\mathrm{H}_{2}$ addition on the cylinder pressure and heat release process for $30 \%$ load operation. Compared to 50 and $70 \%$ load operation, the addition of $\mathrm{H}_{2}$ at $30 \%$ load had mild effect on the cylinder pressure and also peak cylinder pressure. As shown in Figure 108 and Figure 109, the addition of $\mathrm{H}_{2}$ 
below $6 \%$ had a negligible effect on the cylinder pressure after combustion was initiated including the peak cylinder pressure and the phasing when peak cylinder pressure was observed. Further increasing the addition of $\mathrm{H}_{2}$ beyond 6\% slightly increased the peak cylinder pressure observed at a retarded phasing. As shown in Figure 110, the addition of $\mathrm{H}_{2}$ at $30 \%$ load retarded the initiation of premixed combustion, enhanced premixed combustion, inhibited the early stage diffusion combustion and slightly enhanced the late stage diffusion combustion. With the addition $\mathrm{H}_{2}$ over $6 \%$, the late stage diffusion combustion developed into a third heat release peak. Further increasing the amount of $\mathrm{H}_{2}$ advanced and enhanced the third heat release peak until it dominated the heat release process. This might be due to the gradual development of the healthy $\mathrm{H}_{2}$ flame. As shown in Figure 111, the addition of $\mathrm{H}_{2}$ at $30 \%$ load enhanced slightly the peak heat release rate and retarded its phasing. Compared to that of 50 and $70 \%$ load with peak heat release rate observed at diffusion combustion, the peak heat release rate was observed in the premixed combustion stage when operated at $30 \%$ load. In comparison, the diffusion combustion was relatively weak for low load operation.

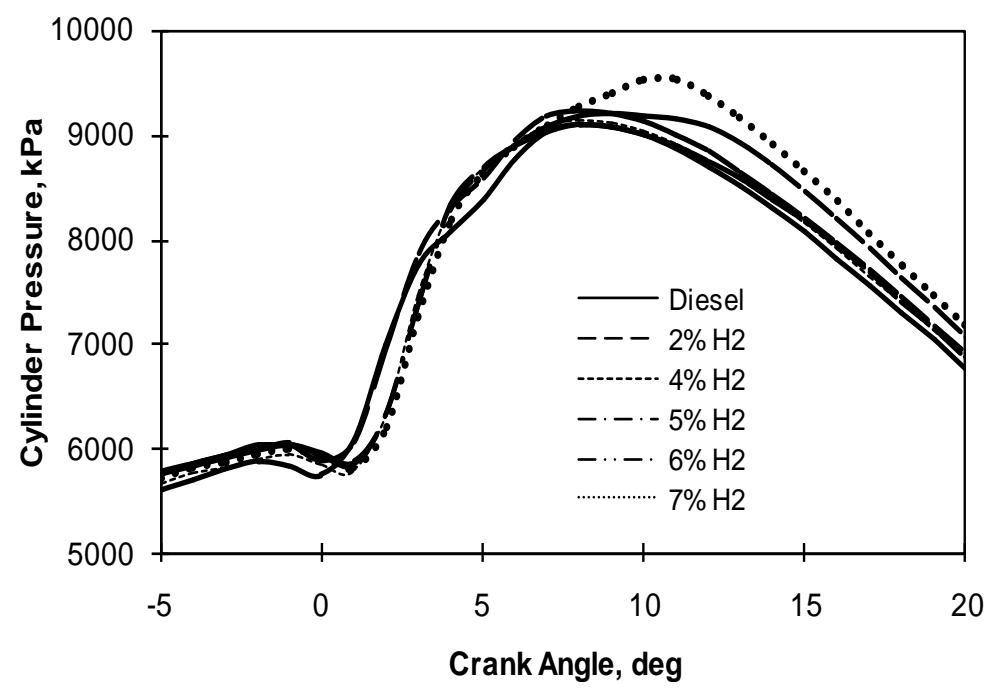

Figure 108 Effect of $\mathrm{H}_{2}$ Addition on Cylinder Pressure, N=1200 RPM, 30\% Load 


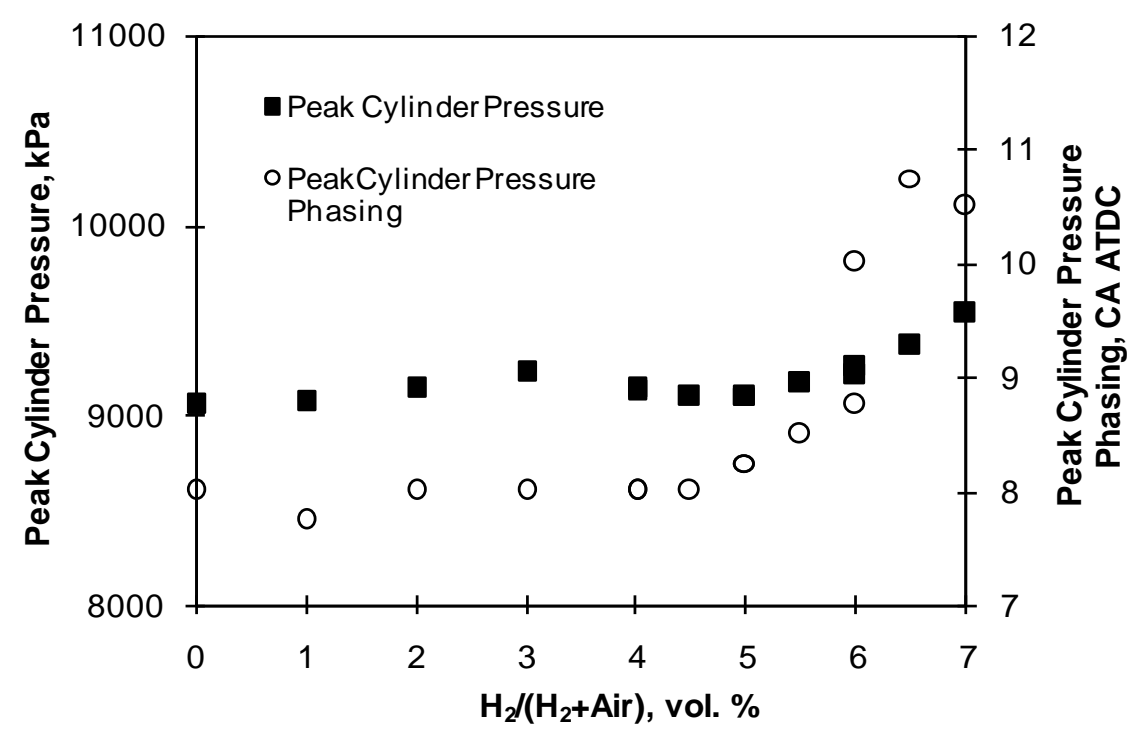

Figure 109 Effect of $\mathrm{H}_{2}$ Addition on Peak Cylinder Pressure and Its Phasing, $\mathrm{N}=1200$ RPM, 30\% Load

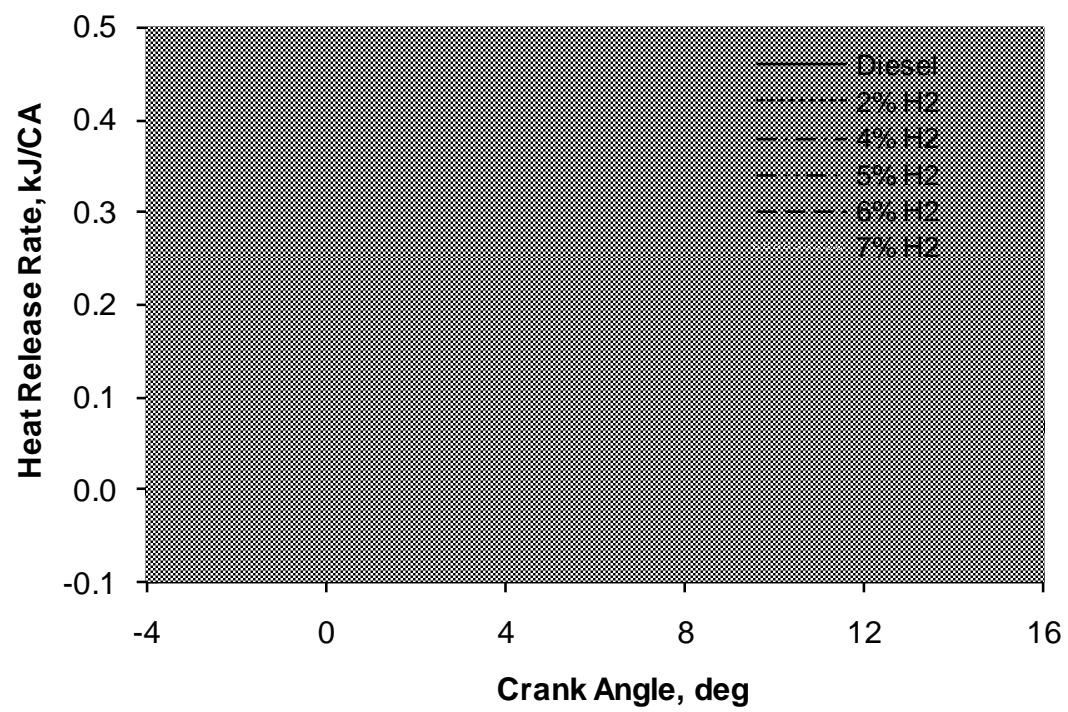

Figure 110 Effect of $\mathrm{H}_{2}$ Addition on Heat Release Rate, N=1200 RPM, 30\% Load 


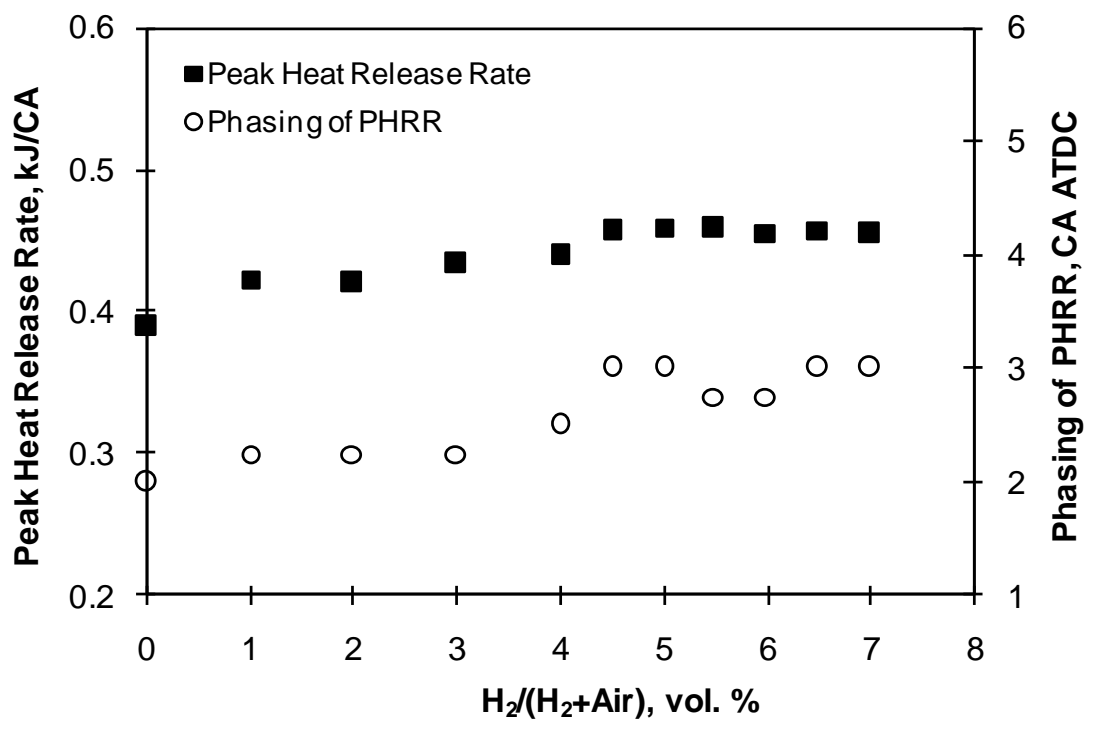

Figure 111 Effect of $\mathrm{H}_{2}$ Addition on Peak Heat Release Rate and Its Phasing, $\mathrm{N}=1200$ RPM, 30\% Load

Figure 112 to Figure 115 shows the effect of $\mathrm{H}_{2}$ addition on the cylinder pressure and heat release process when operated at 15\% load. Compared to medium and high load operation ( $>30 \%$ load), the addition of $\mathrm{H}_{2}$ at $15 \%$ load reduced the peak cylinder pressure, which was observed at a retarded phasing as shown in Figure 112 and Figure 113. As shown in Figure 114, the retarded peak cylinder pressure was due to the retarded combustion phasing. As shown in Table 23, the retarding in combustion phasing with the addition of $\mathrm{H}_{2}$ at $15 \%$ load was mainly due to the retarded injection timing. In comparison, the effect of $\mathrm{H}_{2}$ addition on ignition delay was negligible. Similar to $30 \%$ load operation, the peak heat release rate was observed in premixed combustion as shown in Figure 114. In comparison, the diffusion combustion becomes extremely weak. The addition of $\mathrm{H}_{2}$ retarded the premixed combustion but slightly enhanced the diffusion combustion. 


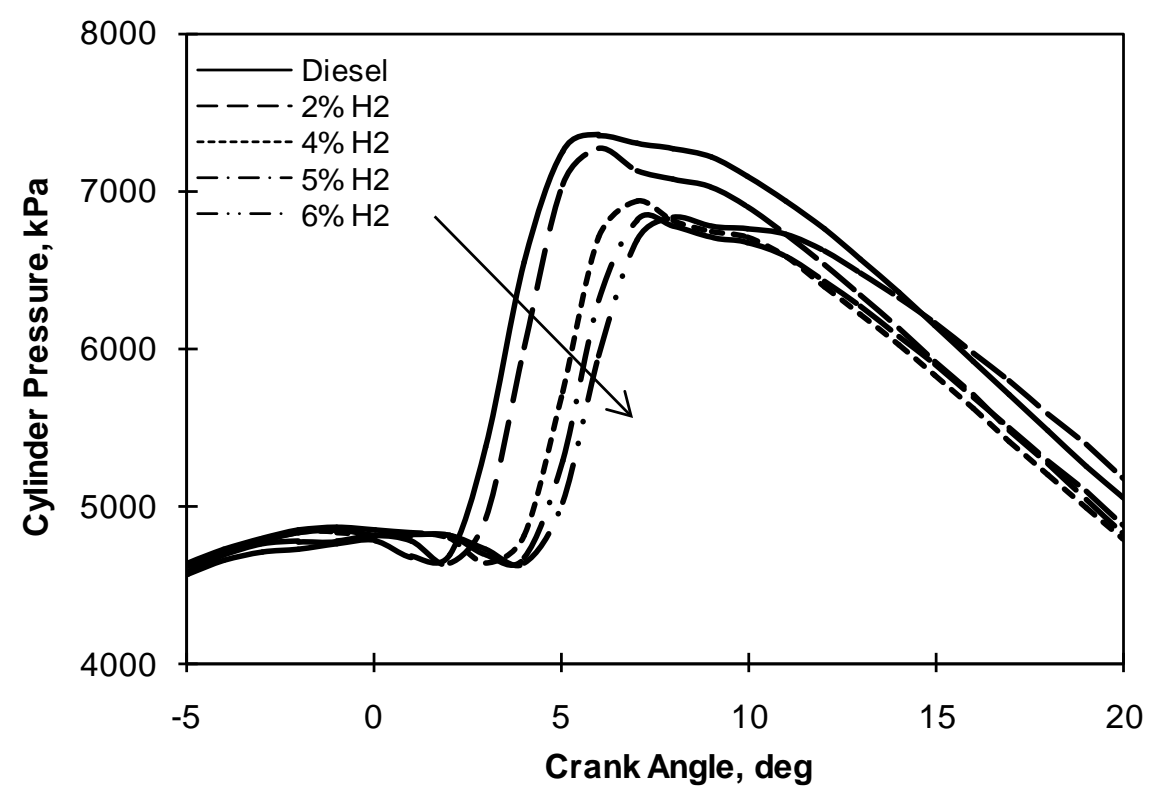

Figure 112 Effect of $\mathrm{H}_{2}$ Addition on Cylinder Pressure, N=1200 RPM, 15\% Load

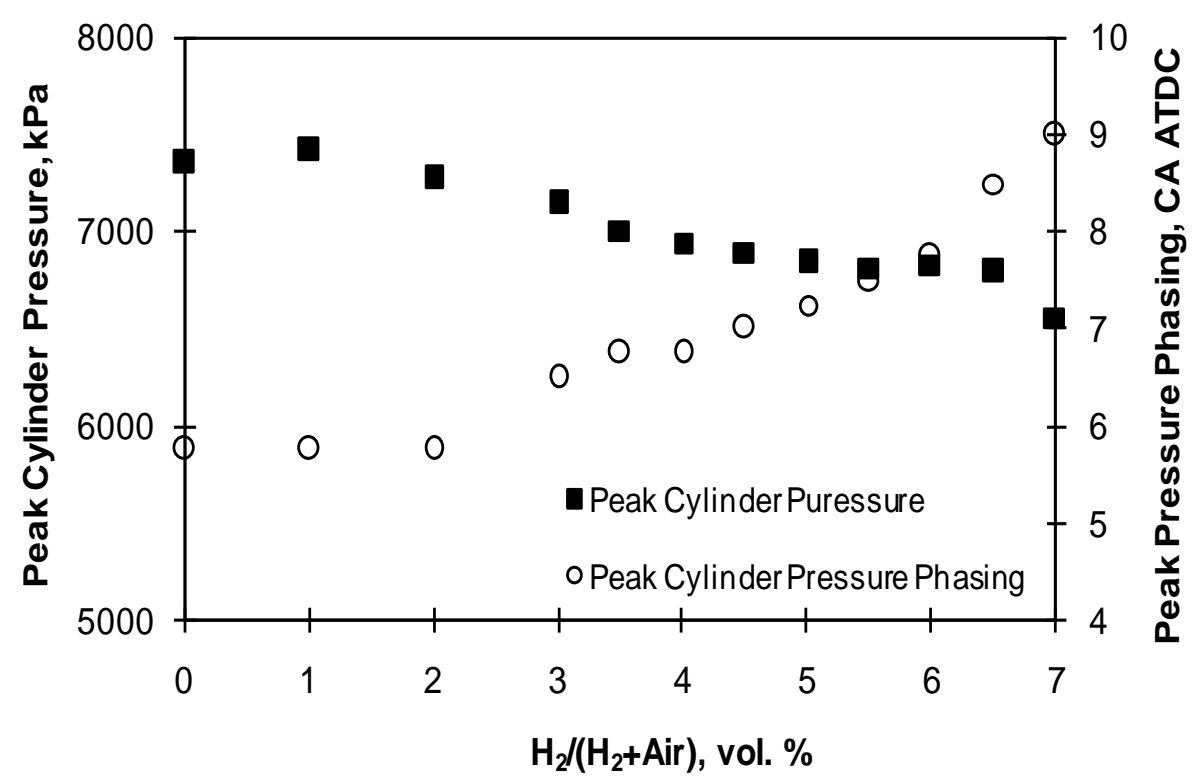

Figure 113 Effect of $\mathrm{H}_{2}$ Addition on Peak Cylinder Pressure and Its Phasing, N=1200 RPM, 15\% Load 


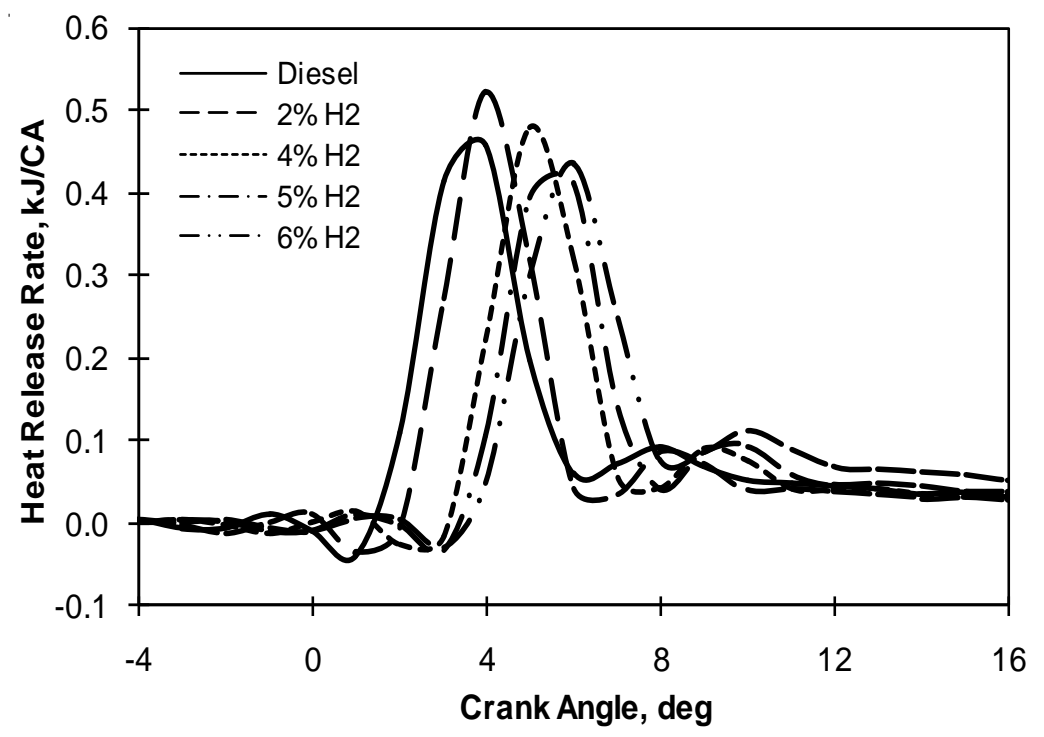

Figure 114 Effect of $\mathrm{H}_{2}$ Addition on Heat Release Rate, N=1200 RPM, 15\% Load

Table 23 Effect of $\mathrm{H}_{2}$ Addition on SOI, SOC, and Ignition Delay When Operated at 1200 RPM, 15\% Load

\begin{tabular}{|c|c|c|c|}
\hline $\begin{array}{c}\mathbf{H}_{\mathbf{2}} /\left(\mathrm{H}_{\mathbf{2}}+\text { Air), vol. }\right. \\
\mathbf{\%}\end{array}$ & SOI, CA ATDC & SOC, CA ATDC & $\begin{array}{c}\text { Ignition Delay, } \\
\text { CA }\end{array}$ \\
\hline 0 & -2.50 & 1.62 & 4.12 \\
\hline 2 & -2.05 & 2.25 & 4.30 \\
\hline 4 & -1.00 & 3.35 & 4.35 \\
\hline 5 & -0.50 & 3.70 & 4.20 \\
\hline 6 & -0.15 & 4.02 & 4.17 \\
\hline
\end{tabular}




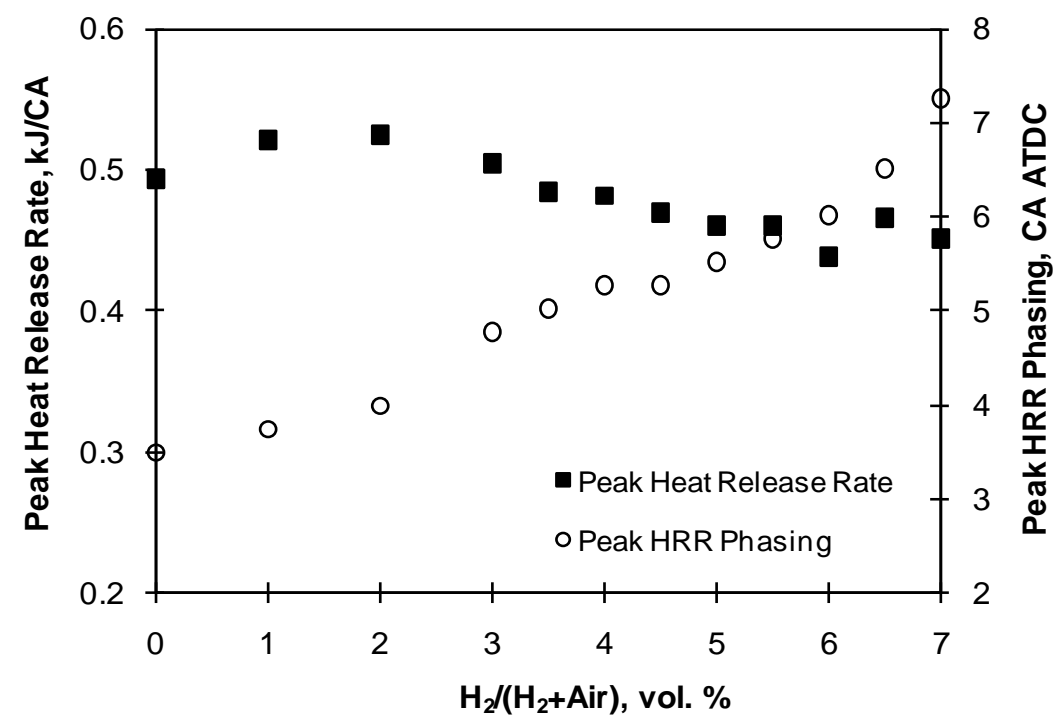

Figure 115 Effect of $\mathrm{H}_{2}$ Addition on Peak Heat Release Rate and Its Phasing, $\mathrm{N}=1200$ RPM, 15\% Load

Figure 116 to Figure 119 shows the effect of $\mathrm{H}_{2}$ addition on cylinder pressure and heat release process at $10 \%$ load. As shown in Figure 116, the addition of $\mathrm{H}_{2}$ at $10 \%$ load retarded the initiation of combustion and substantially reduced the cylinder pressure after the combustion was initiated. As shown in Figure 117, the addition of a relatively small amount of $\mathrm{H}_{2}(<4 \%)$ reduced slightly the peak cylinder pressure observed at gradually retarded phasing. Further increasing the addition of $\mathrm{H}_{2}$ beyond $4.5 \%$ reduced the peak cylinder pressure and substantially retarded the phasing when the peak cylinder pressure was observed. As shown in Figure 118, the retarded peak cylinder pressure was due mainly to the retarded combustion phasing with the addition of less than $5 \% \mathrm{H}_{2}$. Further increasing the addition of $\mathrm{H}_{2}$ beyond 5\% retarded the combustion phasing and substantially inhibited the premixed combustion process, which resulted in a much enhanced late diffusion combustion compared to pure diesel combustion. As shown in Table 24, the retarded combustion phasing with $\mathrm{H}_{2}$ addition was also due mainly to the retarded injection timing with notable contribution of lengthened ignition delay for the 
addition of $\mathrm{H}_{2}$ over $6 \%$. As shown in Figure 119, the significant effect of $\mathrm{H}_{2}$ addition on peak heat release rate was observed when the amount of $\mathrm{H}_{2}$ added reached 5\%.

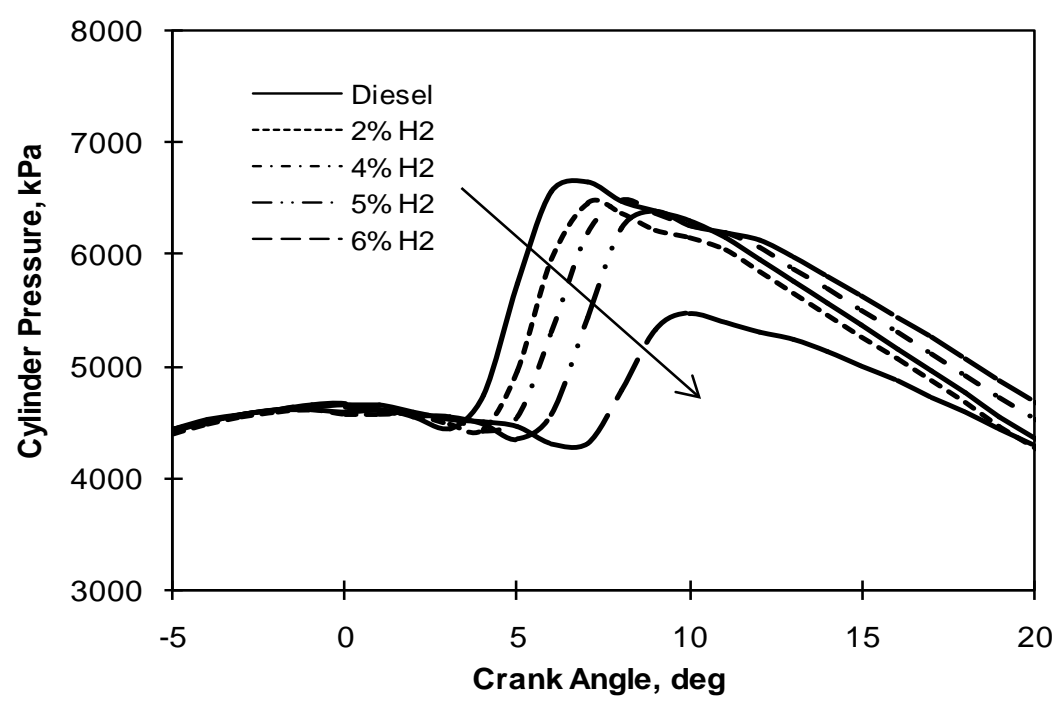

Figure 116 Effect of $\mathrm{H}_{2}$ Addition on Cylinder Pressure, N=1200 RPM, 10\% Load

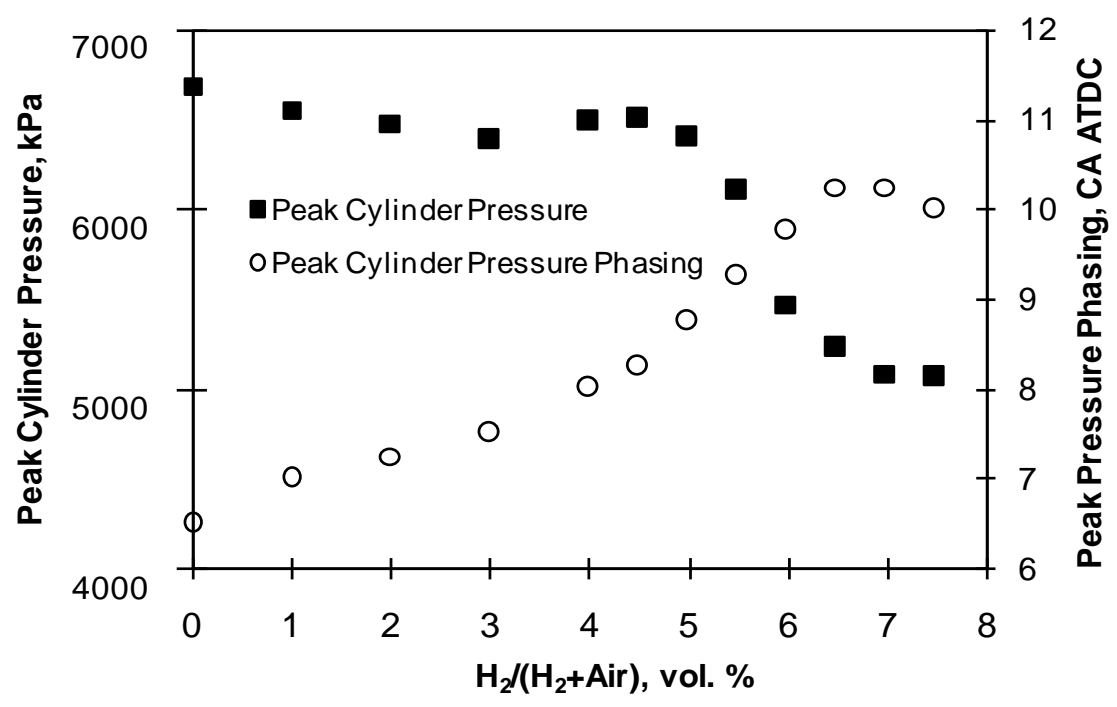

Figure 117 Effect of $\mathrm{H}_{2}$ Addition on Peak Cylinder Pressure and Its Phasing, N=1200 RPM, 10\% Load 


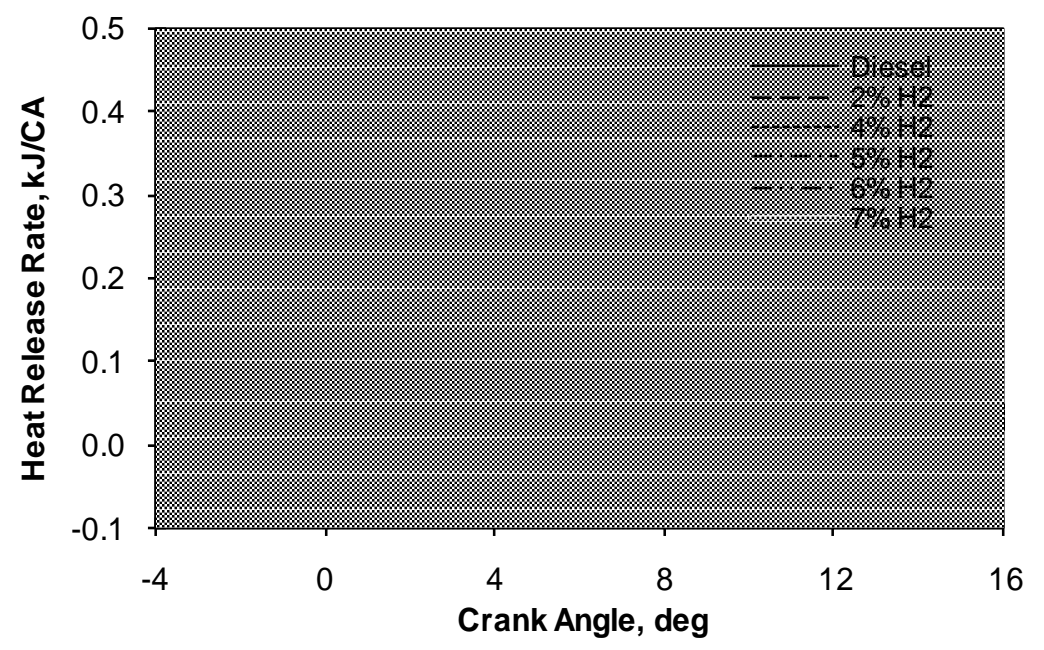

Figure 118 Effect of $\mathrm{H}_{2}$ Addition on Heat Release Rate, N=1200 RPM, 10\% Load

Table 24 Effect of $\mathrm{H}_{2}$ Addition on SOI, SOC, and Ignition Delay When Operated at 1200 RPM, 10\% Load

\begin{tabular}{|c|c|c|c|}
\hline $\begin{array}{c}\mathbf{H}_{\mathbf{2}} /\left(\mathbf{H}_{\mathbf{2}}+\text { Air), }\right. \\
\text { vol. } \%\end{array}$ & SOI, CA ATDC & SOC, CA ATDC & $\begin{array}{c}\text { Ignition Delay, } \\
\text { CA }\end{array}$ \\
\hline 0 & -1.10 & 3.18 & 4.28 \\
\hline 2 & -0.35 & 3.80 & 4.15 \\
\hline 4 & 0.0 & 4.36 & 4.35 \\
\hline 5 & 0.90 & 5.22 & 4.32 \\
\hline 6 & 1.90 & 6.54 & 4.64 \\
\hline 7 & 2.20 & 7.15 & 4.95 \\
\hline
\end{tabular}

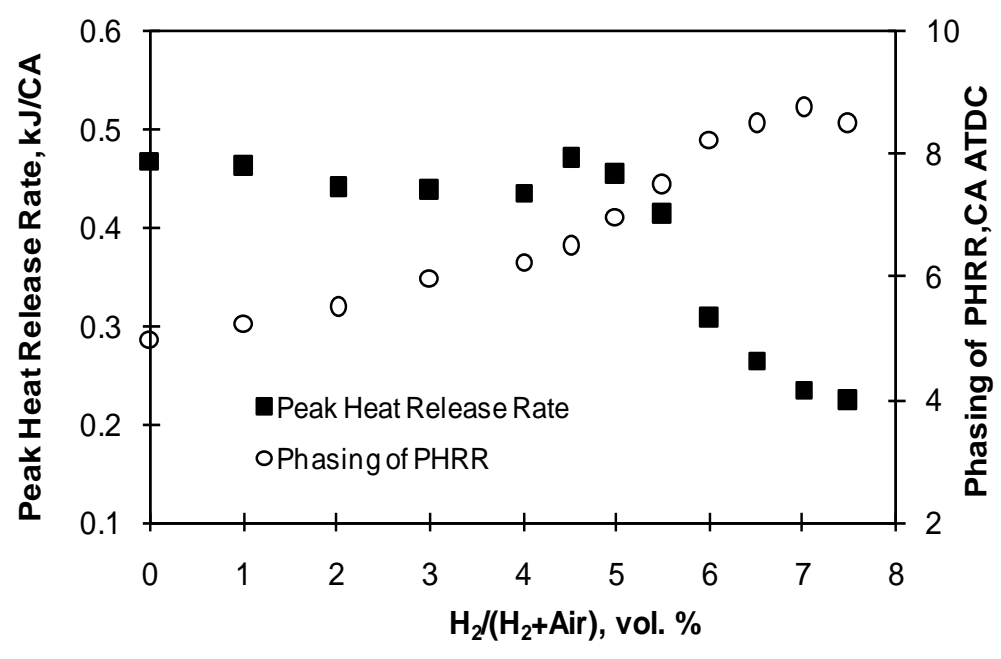

Figure 119 Effect of $\mathrm{H}_{2}$ Addition on Peak Heat Release Rate and Its Phasing, $\mathrm{N}=1200$ RPM, 10\% Load 
Figure 120 shows the effect of engine load on the heat release process of pure diesel operation. The increase in engine load advanced the combustion phasing, inhibited the heat release process of the premixed combustion with significantly enhanced and longer diffusion combustion. When operated at low load, the peak heat release rate was observed at premixed combustion. When operated at high load, the featured injection of large amount of diesel fuel, and also higher compression temperature and pressure contributed to the weak premixed combustion. In comparison, the mixing controlled diffusion combustion was substantially enhanced and lengthened. The diffusion combustion gradually developed into the main combustion process and dominated the heat release process.

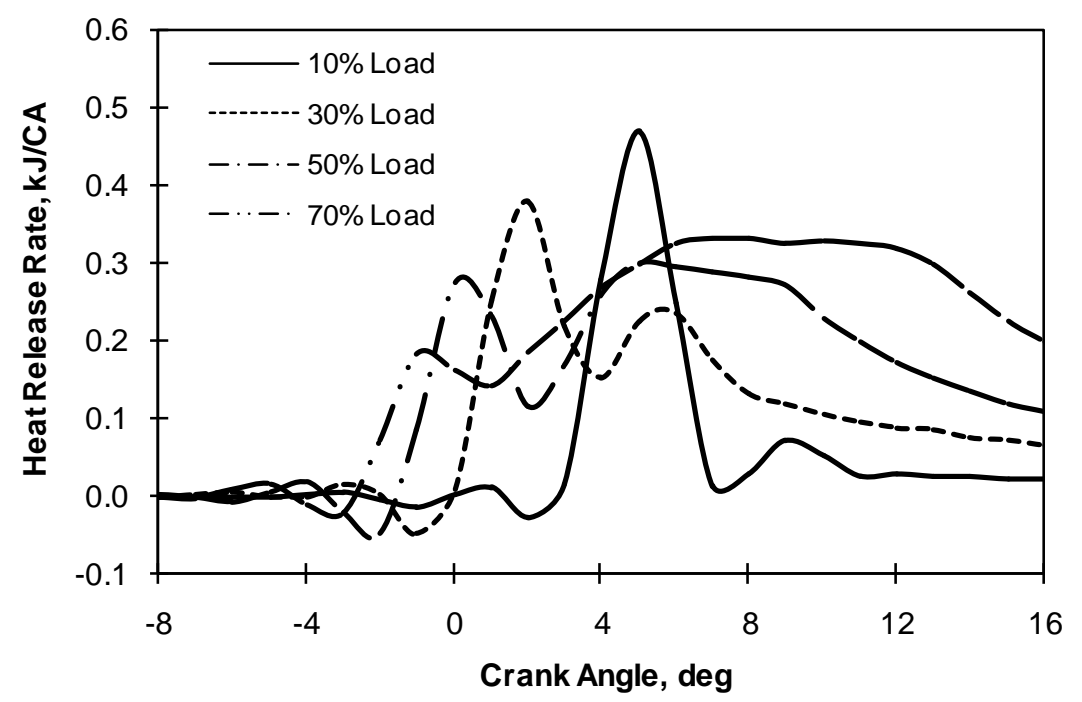

Figure 120 Effect of Engine Load on Heat Release Process, N=1200 RPM, Diesel Only

Figure 121 shows the effect of engine load on the heat release process of $\mathrm{H}_{2}$ diesel dual fuel operation with the addition of $6 \% \mathrm{H}_{2}$. Similar to pure diesel operation, the increase in the engine load advanced the phasing of both premixed and diffusion combustion resulted from the advanced fuel injection. The maximum heat release rate of 
premixed combustion increased first and then dropped gradually with the development of strong diffusion combustion. With the increase in the engine load, the burning of the increasing amount of $\mathrm{H}_{2}$ produced a unique and featured heat release peak as shown Figure 121 for 50 and $70 \%$ load operation. The diesel engine featured two-stage (premixed and diffusion diesel combustion) developed gradually into a three-stage combustion process including premixed and diffusion combustion of diesel fuel, and fast combustion of $\mathrm{H}_{2}$ burned by the turbulent flames as shown in Figure 121 for $70 \%$ load operation with the addition of $6 \% \mathrm{H}_{2}$.

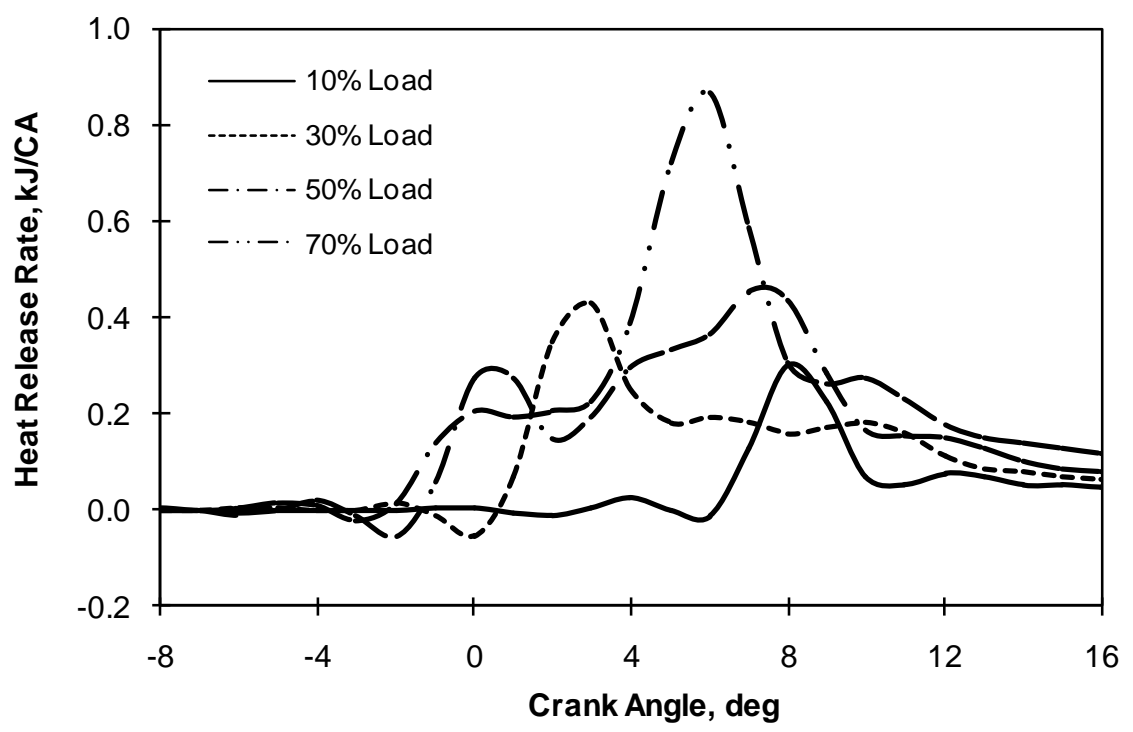

Figure 121 Effect of Engine Load on Heat Release Process, N=1200 RPM, $\mathrm{H}_{2} /\left(\mathrm{H}_{2}+\right.$ Air $)=6 \%$, vol.

\subsection{Summary}

The effect of the addition of $\mathrm{H}_{2}$, engine load, and engine speed on performance, combustion, and exhaust emissions of a 2004 Mack MP7 355E diesel engine has been experimentally investigated without modifying the engine control and fuel injection strategies. Following is a brief summary based on the results obtained in this research: 
- The addition of $\mathrm{H}_{2}$ at 10 to $20 \%$ load had a weak effect on $\mathrm{NO}_{\mathrm{x}}$ emissions with the exception of $10 \%$ load. The addition of a relatively large amount of $\mathrm{H}_{2}$ addition (4-7.5\%) at $10 \%$ load reduced the $\mathrm{NO}_{\mathrm{x}}$ emissions. When operated at medium to high load (30-70\%) operation, the addition of a small amount of $\mathrm{H}_{2}$ ( $<4 \%$ for $30 \%$ load, $<3 \%$ for $50 \%$ load, and $<4 \%$ for $70 \%$ load) reduced slightly on the emissions of $\mathrm{NO}_{\mathrm{x}}$. The addition of a relatively large amount of $\mathrm{H}_{2}(>5 \%$ for $30 \%$ load, $>3 \%$ for $50 \%$ load, and $>5 \%$ for $70 \%$ load) increased the emissions of $\mathrm{NO}_{\mathrm{x}}$. When operated at full load, the addition of $\mathrm{H}_{2}$ had negligible effect on $\mathrm{NO}_{\mathrm{x}}$ emissions with the addition of up to $5 \% \mathrm{H}_{2}$. When measured using the 13-mode ESC, the addition of $2 \% \mathrm{H}_{2}$ had negligible effect on $\mathrm{NO}_{\mathrm{x}}$ emissions. The addition of $4 \% \mathrm{H}_{2}$ was shown to increase from 2.02 to $2.10 \mathrm{~g} / \mathrm{bhp}-\mathrm{hr}$ (+4\%) compared to pure diesel.

- The addition of $\mathrm{H}_{2}$ into this diesel engine reduced the emissions of PM. The extent of reduction in PM emissions depended on the amount of $\mathrm{H}_{2}$ added and engine load. With the addition of $\mathrm{H}_{2}$ up to $7.5 \%$ at $10-70 \%$ load, the maximum PM reduction of 65 to $80 \%$ was obtained. The PM emissions measured using the 13-mode ESC was reduced from 0.040 to 0.033 (-17.5\%) and $0.029 \mathrm{~g} / \mathrm{bhp}-\mathrm{hr}$ (27.5\%) with the addition of $\mathrm{H}_{2}$ at 2 and $4 \%$, respectively.

- The addition of $\mathrm{H}_{2}$ reduced substantially the emissions of $\mathrm{CO}$ when operated at 10 to $20 \%$ load. When operated at 30 to $100 \%$ load, the addition of small amount of $\mathrm{H}_{2}$ ( $<2 \%$ for $30 \%$ load, $<3 \%$ for $50 \%$ load, $<4 \%$ for 70 and $100 \%$ load) increased the emissions of CO. Increasing the amount of $\mathrm{H}_{2}$ corresponded to each load reduced the emissions of CO. When measured using the 13-mode ESC, the 
addition of $2 \% \mathrm{H}_{2}$ into the diesel engine reduced $\mathrm{CO}$ emissions reduced $\mathrm{CO}$ emissions from 0.76 to $0.74 \mathrm{~g} / \mathrm{bhp}-\mathrm{hr}(-2.6 \%)$. The addition of $4 \% \mathrm{H}_{2}$ increased CO emissions from 0.76 to $0.82 \mathrm{~g} / \mathrm{bhp}-\mathrm{hr}$ (+7.9\%).

- The addition of $\mathrm{H}_{2}$ reduced the emissions of $\mathrm{HC}$ with the exception of $10 \%$ load operation. When operated at $10 \%$ load, the addition of $\mathrm{H}_{2}$ less than $5 \%$ had a negligible effect on the emissions of $\mathrm{HC}$. The addition of $\mathrm{H}_{2}$ beyond $5 \%$ reduced substantially the emissions of HC. When measured using the 13-mode ESC, the addition of $2 \% \mathrm{H}_{2}$ increased $\mathrm{HC}$ emissions from 0.072 to $0.078 \mathrm{~g} / \mathrm{bhp}-\mathrm{hr}$ (+8.3\%). The addition of $4 \% \mathrm{H}_{2}$ had a negligible effect on $\mathrm{HC}$ emissions.

- The addition of a relatively small amount of $\mathrm{H}_{2}(<1 \%)$ lowered the BTE. The desirable positive effect of $\mathrm{H}_{2}$ in improving the BTE was obtained with the addition of $\mathrm{H}_{2}$ at relatively large amounts (3-7.5\%) at 50 and $70 \%$ load. With the addition of $6 \% \mathrm{H}_{2}$, the improvement to the BTE was found to be $0.8-3.4 \%$ for 20 70\% load operation. When operated at low load, the positive effect of $\mathrm{H}_{2}$ addition on the BTE was not observed.

- The addition of a large amount of $\mathrm{H}_{2}(6 \%)$ at $70 \%$ load increased the peak cylinder pressure and peak heat release rate from 153.7 to 178.5 bar and 0.33 to $0.87 \mathrm{~kJ} / \mathrm{CA}$, respectively. In comparison with the addition of a large amount of $\mathrm{H}_{2}$ (6\%) at $15 \%$ load decreased the peak cylinder pressure and peak heat release rate from 73.5 to $68.3 \mathrm{bar}$ and 0.46 to $0.44 \mathrm{~kJ} / \mathrm{CA}$, respectively. 


\section{CONCLUSIONS AND RECOMMENDATIONS}

This research investigated the performance, combustion, and emission characteristics of $\mathrm{H}_{2}$-enriched diesel engines using a 1999 Cummins ISM370ESP and a 2004 Mack MP7 355E. The $\mathrm{H}_{2}$ was mixed to the intake air well before entering the intake manifold with suitable backfire protection devices installed. The engine load was varied from 10 to $100 \%$ with the addition of $\mathrm{H}_{2}$ up to $7.5 \%$ into the intake mixture. The potential of $\mathrm{H}_{2}$ enriching in improving the brake thermal efficiency and associated penalty in $\mathrm{NO}_{\mathrm{x}}$ emissions was discussed.

\subsection{Conclusions}

Based on the experimental data obtained in this research, the following conclusion can be drawn:

- The addition of $\mathrm{H}_{2}$ into these two heavy-duty diesel engines reduced the emissions of $\mathrm{PM}, \mathrm{CO}, \mathrm{HC}$, and $\mathrm{CO}_{2}$.

- The addition of $\mathrm{H}_{2}$ to the Cummins engine increased the emissions of $\mathrm{NO}_{\mathrm{x}}$ when operated at medium to high load. The substantial reduction in $\mathrm{NO}_{\mathrm{x}}$ emissions was only observed with the addition of relatively large amount of $\mathrm{H}_{2}$ when operated under a very low narrow low load operational region.

- The addition of $\mathrm{H}_{2}$ to 2004 Mack MP7 355E has mild effect on $\mathrm{NO}_{\mathrm{x}}$ emissions. The addition of medium amount of $\mathrm{H}_{2}$ under medium to high load slightly reduced the emissions of $\mathrm{NO}_{\mathrm{x}}$. The substantial reduction in $\mathrm{NO}_{\mathrm{x}}$ emissions were 
only observed with the addition of relatively large amount of $\mathrm{H}_{2}$ when operated under very narrow low load operational region.

- The substantial reduction of $\mathrm{NO}_{\mathrm{x}}$ emissions through the supplementation of a small amount of $\mathrm{H}_{2}$ to heavy-duty diesel engines seems infeasible.

- When operated at medium to high load ( $>5 \%)$, a featured three-stage heat release process of $\mathrm{H}_{2}$-diesel dual fuel engine was observed. The unique high heat release rate observed in diffusion combustion was a combination of diesel diffusion combustion and the turbulent flames controlled combustion of $\mathrm{H}_{2}$-air mixture ignited at multi-point by diesel sprays.

- The addition of relatively large amount of $\mathrm{H}_{2}$ to heavy-duty diesel engines was shown to improve the brake thermal efficiency. In comparison, the addition of relatively small amounts was found to deteriorate the brake thermal efficiency. The addition of $\mathrm{H}_{2}$ at low load should be avoided.

- The addition of $\mathrm{H}_{2}$ relatively large amount of $\mathrm{H}_{2}$ at high load improved the BTE and substantially increased the peak cylinder pressure, which raised the concerns to safety and durability.

- The addition of a relatively large amount of $\mathrm{H}_{2}$ at high load significantly increased the peak cylinder pressure. The addition of $6 \% \mathrm{H}_{2}$ to Cummins engine increased peak pressure from 107.2 to 120.9 bar $(+12.8 \%)$. In comparison, the addition of $6 \% \mathrm{H}_{2}$ to MACK engine increased cylinder pressure from 153.7 to 178.5 bar $(+16.1 \%)$. 


\subsection{Recommendations}

Based on the results obtained in this research and those reported in the literature, I would like to make the following recommendations for future research in this area.

- To optimize engine control strategies to maximize the positive effect of $\mathrm{H}_{2}$ enrichment in improving the brake thermal efficiency. As shown by the combustion data, the addition of $\mathrm{H}_{2}$ at high load enhanced the diffusion combustion process, which makes the injection timing away from the optimized one. Further optimization of injection timing could further improve the BTE.

- The application of $\mathrm{H}_{2}$ enrichment in a light-duty diesel engine. The data reported in literature demonstrated substantial improvement to the thermal efficiency $(+29.2$ and $+37.4 \%$ with the addition of $6 \% \mathrm{H}_{2}$ into intake mixture for 5.4 bar and 2.7 bar BMEP, respectively) [McWilliam et al., 2008]. This may make $\mathrm{H}_{2}$ enrichment very attractive in improving the brake thermal efficiency of the diesel engine with the $\mathrm{NO}_{\mathrm{x}}$ emissions reduced through the application of EGR and even SCR.

- The exhaust emissions of $\mathrm{H}_{2}$ contribute to the deterioration of the brake thermal efficiency [Gatts et al., 2009]. Further literature review and experimental work should be conducted to explore the approaches which can utilize the unburned $\mathrm{H}_{2}$ presented in the exhaust gas of $\mathrm{H}_{2}$-diesel dual fuel engine. The enhancement of $\mathrm{H}_{2}$

to the operation of after-treatment system may be considered as one of the approaches. 


\section{REFERENCES}

1. Bika, A.S., Franklin, L.M., and Kittelson, D.B., "Emission Effects of Hydrogen as a Supplement Fuel with Diesel and Bio-Diesel”, SAE Paper 2008-01-0648, University of Minnesota, 14 April 2008.

2. Boehman, A.L., and Corre, O.L., "Combustion of Syngas in Internal Combustion Engines”, Combustion Science and Technology, Vol. 180 (2008), pp. 1193-1206.

3. Code of Federal Regulations (1), Title 40, Part 86 Subpart N, "Emission Regulations for New Otto-Cycle and Diesel Heavy-Duty Engines", Washington D.C, 1998.

4. Code of Federal Regulations (2), Title 40, Part 86 Subpart N.1310-90, "Emission Regulations for New Otto-Cycle and Diesel Heavy-Duty Engines; Gaseous and Particulate Exhaust Test Procedures: Exhaust Gas Sampling and Analytical System of Diesel Engines”, Washington D.C, 1998, pp. 169-178.

5. Code of Federal Regulations (3), Title 40, Part 86 Subpart N.1312-88, "Emission Regulations for New Otto-Cycle and Diesel Heavy-Duty Engines; Gaseous and Particulate Exhaust Test Procedures: Weighing Chamber and Microgram Balance Specifications”, Washington D.C, 1998, pp. 188-192.

6. Code of Federal Regulations (4), Title 40, Part 86 Subpart N.1332-90, "Emission Regulations for New Otto-Cycle and Diesel Heavy-Duty Engines; Gaseous and Particulate Exhaust Test Procedures: Engine Mapping Procedures”, Washington D.C, 1998, pp. 220-223.

7. Das, L.M., "Hydrogen Engines: A Review of the Past and A Look into the Future”, International Journal of Hydrogen Energy, Vol. 15 (1990), pp. 425-443.

8. Furuhama, S., "State of the Art and Future Trends in Hydrogen-Fuelled Engines", International Journal of Vehicle Design, Vol. 4 (1983), pp. 359-385.

9. Furuhama, S. and Fukuma, T., "High Output Power Hydrogen Engine with High Pressure Fuel Injection, Hot Surface Ignition and Turbo-charging”, International Journal of Hydrogen Energy, Vol. 11 (1986), pp. 399-407.

10. Gatts, T., Liew, C., Liu, S., Li, H., Spencer, T., and Clark, N., “An Experimental Investigation of $\mathrm{H}_{2}$ Emissions of a Heavy-Duty $\mathrm{H}_{2}$-Diesel Dual Fuel Engine”, Eastern States of the Combustion Institute Conference, Maryland (2009).

11. Gopalakrishnan, R., Throop, M.J., Richardson, A., and Lapetz, J.M., "Engineering the Ford $\mathrm{H}_{2}$ IC Engine Powered E-450 Shuttle Bus", SAE Paper 2007-01-4095, Ford Motor Co., 29 October 2007.

12. Gopal, G., Rao, P.S., Gopalakrishnan, K.V., and Murthy, B.S., "Use of Hydrogen in Dual-Fuel Engines", International Journal of Hydrogen Energy, Vol. 7 (1982), pp. 267-272.

13. Heywood, J.B., Internal Combustion Engine Fundamentals, McGraw-Hill, New York City, NY, (1988). 
14. Homan, H.S., Reynolds, R.K., Deboer, P.C.T., and Mclean, W.J., "HydrogenFuelled Diesel Engine without Timed Ignition", International Journal of Hydrogen Energy, Vol. 4 (1979), pp. 315-325.

15. Ikegami, M., Miwa, K., Esaki, M., and Shioji, M., “A Study of Hydrogen Fuelled Compression Ignition Engines”, International Journal of Hydrogen Energy, Vol. 7 (1982), pp. 341-353.

16. Karim, G.A. and Klat, S.R., "Experimental and Analytical Studies of Hydrogen as a Fuel in Dual Fuel Engine”, ASME Paper No. 75-DGP-9 (1982).

17. Karim, G.A., "Hydrogen as a Spark Ignition Engine Fuel”, International Journal of Hydrogen Energy, Vol. 28 (2003), pp. 569-577.

18. Kiesgen, G., Kluting, M., Bock, S., and Fisher, H., "The New 12-cylinder Hydrogen Engine in the 7 Series: The $\mathrm{H}_{2}$ ICE Age Engine Begun”, SAE Paper 2006-01-0431, BMW Group, 3 April 2006.

19. Kumar, M.S., Ramesh, A., and Nagalingam, B., "Use of Hydrogen to Enhance the Performance of a Vegetable Oil Fuelled Compression Ignition Engine", International Journal of Hydrogen Energy, Vol.28 (2003), pp. 1143-1154.

20. Lambe, S.M. and Watsom, H.C., "Low Polluting, Energy Efficient C.I. Hydrogen Engine”, International Journal of Hydrogen, Vol. 17 (1992), pp. 513-525.

21. Li, H.L. and Karim, G.A., "Exhaust Emissions from a Gas Containing Hydrogen Fueled SI engine”, International Journal of Hydrogen Energy, Vol. 30 (2005), pp. 1491-1499.

22. Masood, M., Mehdi, S.N., and Reddy, P.R., “An Experimental Investigations on a Hydrogen-Diesel Dual Fuel Engine at Different Compression Ratios”, Journal of Engineering for Gas Turbines and Power, Vol. 129 (2007), pp. 572-578.

23. Max Machinery, "Instruction Manual 710 Series Fuel Measurement System", 2004, <http://www.maxmachinery.com/pdfs/710m.pdf>

24. Meriam Process Technology, "Laminar Flow Elemnets”, 2010, $<$ http://www.meriam.com/pdf/DataSheets/lfe_datasheet.pdf>

25. McWilliam, L. Megaritis, T., and Zhao, H., "Experimental Investigation of the Effects of Combined Hydrogen and Diesel Combustion on the Emissions of a HSDI Diesel Engine”, SAE 2008-01-1787, Brunel University, UK., 23 June 2008.

26. Munshi, S., Nedelcu, C., Harris, Edwards, J.T., Williams, J.R., Lynch, F., Frailey, M.R., Dixon, G., Wayne, S., and Nine, R., "Hydrogen Blended Natural Gas Operation of a Heavy Duty Turbo-Charged Lean Burn Spark Ignition Engine”, SAE Paper 2004-01-2956, Westport Innovations Inc., 25 October 2004.

27. Saravanan, N. and Nagarajan, G., "An Experimental Investigation of Hydrogen Enriched Air Induction in a Diesel Engine System", International Journal of Hydrogen Energy, Vol. 33 (2008), pp. 1769-1775.

28. Saravanan, N., and Nagarajan, G., "An Experimental Investigation of Hydrogen as a Dual Fuel for Diesel Engine System with Exhaust Gas Recirculation 
Technique”, International. Journal of Hydrogen Energy, Vol. 33 (2008), pp. 422427.

29. Shirk, M.G., McGuire, T.P., Gary, L., Neal, and Haworth, D., "Investigation of a Hydrogen-Assisted Combustion System for a Light-duty diesel vehicles", International Journal of Hydrogen Energy, Vol. 33 (2008), pp. 7237-7244.

30. Sierra Instrument Inc., "Smart-Trak Series 100 Mass Flow Meters and Controllers Technical Data Sheet", October 2008, $<$ http://www.sierrainstruments.com/products/userfiles/file/datasheets/st2.pdf >

31. Stockhausen, W.F., Natikin, R.J., Kabat, D.M., Reams, L., and Tang, X., "Ford P2000 Hydrogen Engine Design and Development Program”, SAE Paper 200201-0240, Ford Motor, 4 March 2002.

32. Tang, X., Kabat, D.M., Natikin, R.J., and Stockhausen, W.F., "Ford P2000 Hydrogen Engine Dynamometer Development”, SAE Paper 2002-01-0242

33. Tincher, R.R., "Evaluation of Heavy-Duty Diesel Engines Regulated Emissions Based on Variation of Fuel Properties by Use of Additives", (MS thesis, West Virginia University, 2007).

34. Tomita, E., Kawahara, N., Piao, Z., Fujita, S., and Hamamoto, Y., "Hydrogen Combustion and Exhaust Emissions Ignited with Diesel Oil in a Dual Fuel Engine”, SAE Paper 2001-01-3503, Okayama University, Japan, 24 September 2001.

35. Topinka, J., Gerty, M.D., and Heywood, J.B., "Knock Behavior of a Lean-Burn, $\mathrm{H}_{2}$ and CO-Enhanced, SI Gasoline Engine Concept", SAE Paper 2004-01-0975, Massachusetts Institute of Technology, 8 March 2004.

36. Varde, K.S. and Frame, G.A., "Hydrogen Aspiration in Direct Injection Type Diesel Engine-its Effect on Smoke and Other Engine Performance Parameters", International Journal of Hydrogen Energy, Vol. 8 (1983), pp. 549-555.

37. White, C.M., Steeper, R.R., and Lutz, A.E., "The Hydrogen-Fuelled Internal Combustion Engine: a Technical Review", International Journal of Hydrogen Energy, Vol.31 (2006), pp. 1292-1350.

38. Wong, J.K.S., "Compression Ignition of Hydrogen in a Direct Injection Diesel Engine Modified to Operate as A Low-Heat-Rejection Engine”, International Journal of Hydrogen Energy, Vol.15 (1990), pp. 507-514. 


\section{APPENDIX}




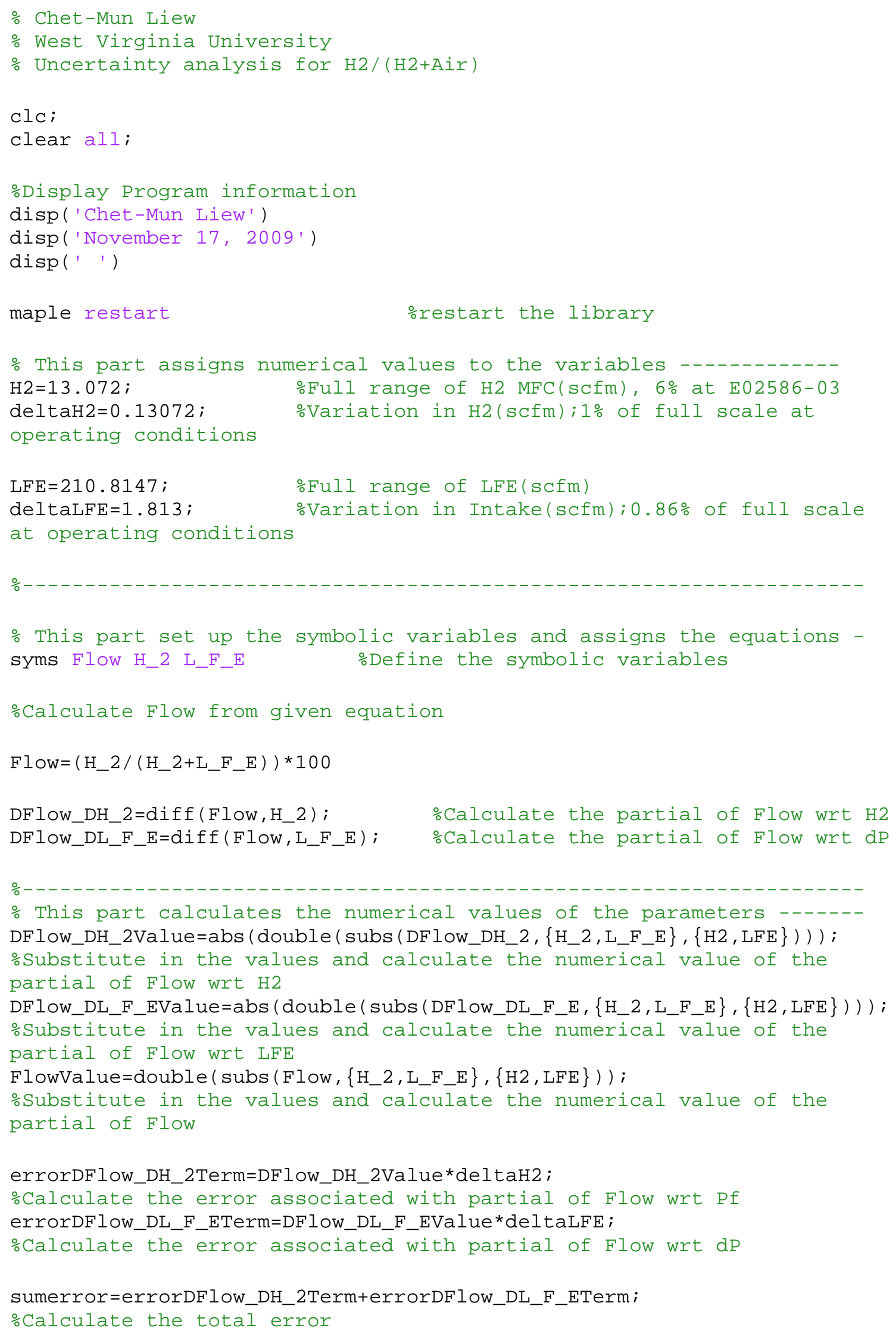




disp('Final Results')
fprintf('Flow= \%6.3f ', FlowValue) \%Display the results
$\quad$ fprintf('+/-\%6.3f $\backslash n$ ', sumerror)
$\%$ The uncertainty result is
$\%$ Flow $=5.839+/-0.102 \%$




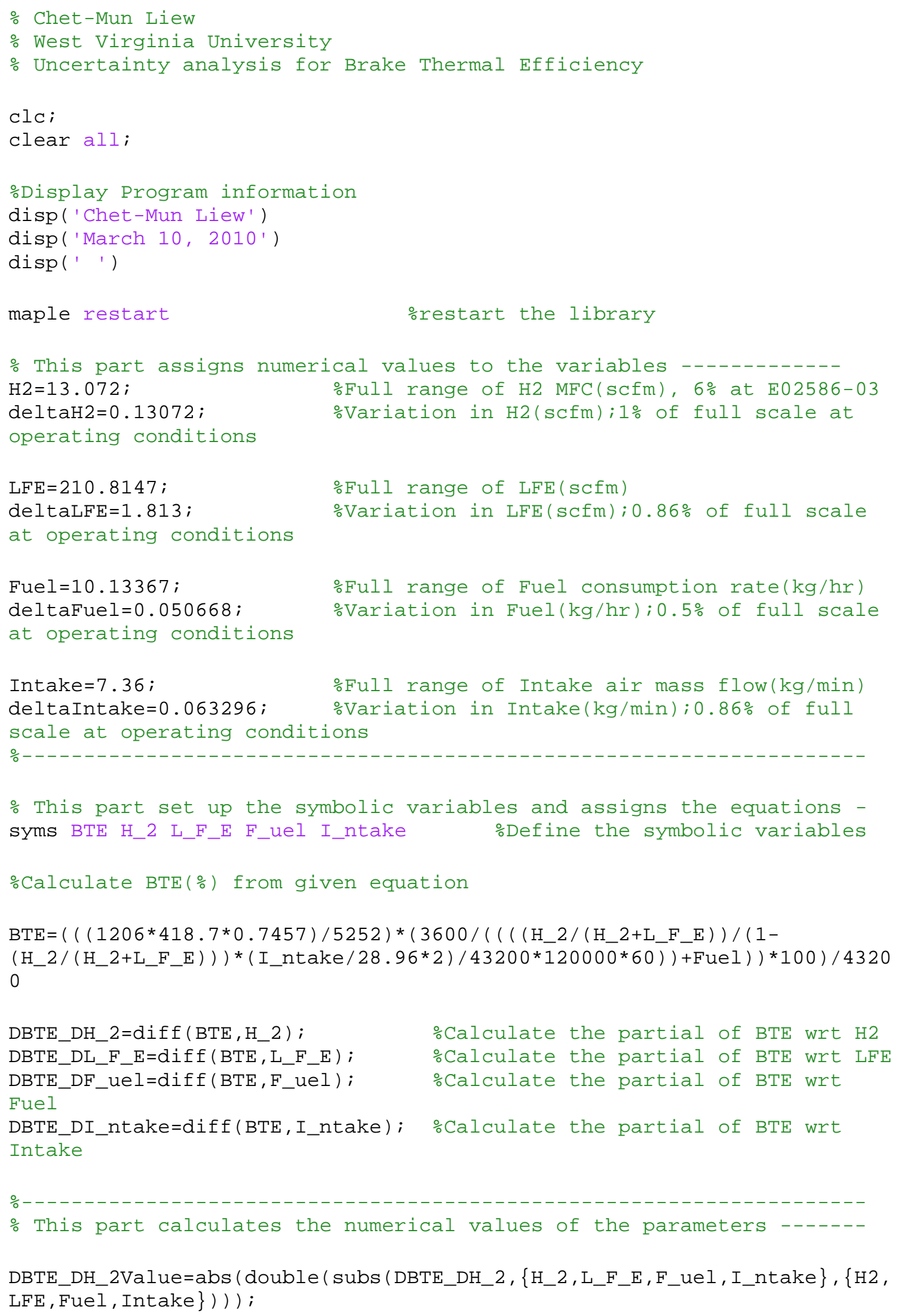


\%Substitute in the values and calculate the numerical value of the partial of BTE wrt H2

DBTE_DL_F_EValue=abs (double (subs (DBTE_DL_F_E, $\{$ H_2, L_F_E, I_ntake $\},\{H 2, L F$ E, Intake\})) );

\%Substitute in the values and calculate the numerical value of the partial of BTE wrt LFE

DBTE_DF_uelValue=abs (double (subs (DBTE_DF_uel, $\{$ H_2, L_F_E $\},\{$ H2, LFE $\}))$ );

\%Substitute in the values and calculate the numerical value of the

partial of BTE wrt Fuel

DBTE_DI_ntakeValue=abs (double(subs (DBTE_DI_ntake, $\{$ H_2, L_F_E, I_ntake $\},\{H$ 2, LFE, Intake\})));

\%Substitute in the values and calculate the numerical value of the partial of BTE wrt Intake

BTEValue $=$ double $\left(\operatorname{subs}\left(B T E,\left\{H \_2, L \_F \_E, F \_u e l, I \_n t a k e\right\},\{H 2, L F E, F u e l\right.\right.$, Intake $\}$ ) );

\%Substitute in the values and calculate the numerical value of the partial of BTE

errorDBTE_DH_2Term=DBTE_DH_2Value*deltaH2;

\%Calculate the error associated with partial of BTE wrt H2

errorDBTE_DL_F_ETerm=DBTE_DL_F_EValue*deltaLFE ;

\%Calculate the error associated with partial of BTE wrt LFE

errorDBTE_DF_uelTerm=DBTE_DF_uelValue*deltaFuel;

\%Calculate the error associated with partial of BTE wrt Fuel

errorDBTE_DI_ntakeTerm=DBTE_DI_ntakeValue*deltaIntake ;

\%Calculate the error associated with partial of BTE wrt Intake

sumerror=errorDBTE_DH_2Term+errorDBTE_DL_F_ETerm+errorDBTE_DF_uelTerm+e rrorDBTE_DI_ntakeTerm ; \%Calculate the total error

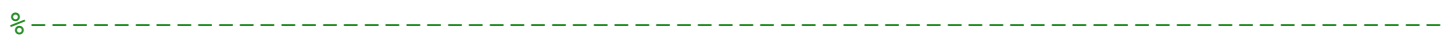

disp('Final Results')

fprintf('BTE $=\% 6.3 f$ ', BTEValue) \%Display the results

fprintf('+/- \%6.3f $\backslash n '$ ', sumerror)

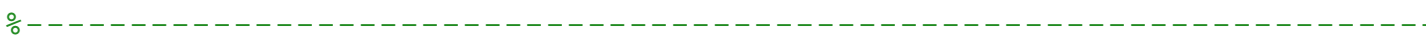

$\%$ The uncertainty result is

$\%$ BTE $=38.830+/-0.361 \%$ 
An Investigation of Hydrogen Supplementation on Combustion and Emissions of Heavy-Duty Diesel Engines

\section{ChetMun Liew}

Thesis Submitted to the

College of Engineering and Mineral Resources

at West Virginia University

in partial fulfillment of the requirements

for the degree of

Master of Science

in

Mechanical Engineering

Department of Mechanical and Aerospace Engineering

APPROVAL OF THE EXAMINING COMMITTEE

Nigel Clark, Ph.D.

Benjamin Shade, Ph.D.

Hailin Li, Ph.D., Chair

Date 